THE ROLE OF JEWISH FEASTS IN JOHN'S GOSPEL

Gerald Wheaton

A Thesis Submitted for the Degree of PhD at the

University of St. Andrews

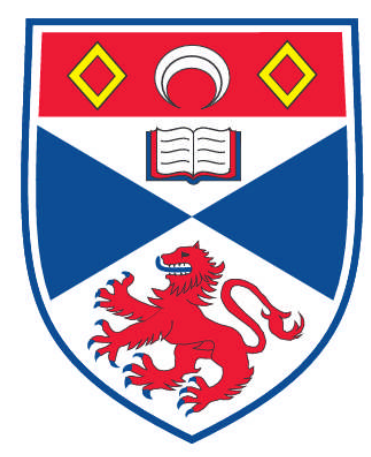

2009

Full metadata for this item is available in the St Andrews Digital Research Repository at:

https: / / research-repository.st-andrews.ac.uk/

Please use this identifier to cite or link to this item: http: //hdl.handle.net/10023/942

This item is protected by original copyright 


\title{
The Role of the Jewish Feasts in John's Gospel
}

\author{
Presented by Gerald Wheaton \\ For the degree of Doctor of Philosophy \\ University of St. Andrews, Scotland \\ On 17 August, 2009
}




\section{Declaration}

I, Gerald Wheaton, hereby certify that this thesis, which is approximately 70,000 words in length, has been written by me, that it is the record of work carried out by me and that it has not been submitted in any previous application for a higher degree.

I was admitted as a research student in November, 2005 and as a candidate for the degree of Doctor of Philosophy in July, 2006; the higher study for which this is a record was carried out in the University of St Andrews between 2006 and 2009.

Date

Signature of candidate

I hereby certify that the candidate has fulfilled the conditions of the Resolution and Regulations appropriate for the degree of Doctor of Philosophy in the University of St Andrews and that the candidate is qualified to submit this thesis in application for that degree.

Date Signature of supervisor

In submitting this thesis to the University of St Andrews we understand that we are giving permission for it to be made available for use in accordance with the regulations of the University Library for the time being in force, subject to any copyright vested in the work not being affected thereby. We also understand that the title and the abstract will be published, and that a copy of the work may be made and supplied to any bona fide library or research worker, that my thesis will be electronically accessible for personal or research use unless exempt by award of an embargo as requested below, and that the library has the right to migrate my thesis into new electronic forms as required to ensure continued access to the thesis. We have obtained any third-party copyright permissions that may be required in order to allow such access and migration, or have requested the appropriate embargo below.

The following is an agreed request by candidate and supervisor regarding the electronic publication of this thesis:

Access to Printed copy and electronic publication of thesis through the University of St Andrews. 


\begin{abstract}
The present work aims to elucidate the role of the Jewish feasts of Passover, Tabernacles and Dedication in the presentation of Jesus in the Fourth Gospel. Specifically, I will seek to gain a clearer understanding of John's appropriation of the symbolic and traditional backgrounds of these feasts by examining pertinent sources from contemporary Judaism and the manner in which John has made use of the traditions preserved therein. Past studies have achieved consensus on certain points of interpretation but overlooked important evidence at other points. Some scholars have also been too quick to cite John's treatment of the feasts as evidence of his anti-Jewish posture in the Gospel as a whole. In what follows, therefore, I will give particular attention to those background sources which have not been accorded due attention. I will also attempt to situate my study within the wider question of Judaism in the Fourth Gospel and to suggest how the results achieved in the end may bear upon ongoing debates on this matter.
\end{abstract}




\section{Table of Contents}

Outline of Thesis (p. 5)

Chapter 1 - Introduction (p. 9)

Chapter 2 - The role and perception of Judaism in John (p. 19)

Chapter 3 - The role of Passover in John (p. 58)

Chapter 4 - The role of Tabernacles in John (p. 94)

Chapter 5 - The role of Dedication John (p. 123)

Chapter 6 - Conclusion (p. 144)

Bibliography (p. 150) 


\section{Outline of Thesis}

I. INTRODUCTION (p. 10)

a. Introduction to the question (p. 10)

b. Review of previous scholarship (p. 11)

c. Method and Statement of Task (p. 18)

II. THE ROLE AND PERCEPTION OF JUDAISM IN JOHN (p. 20)

a. Introduction: Judaism in John (p. 20)

b. Law in John (p. 21)

i. "Law" in John (p. 21)

1. Apart from John 1:17

2. John 1:17

ii. Conclusion (p. 29)

c. Contribution of John 2-4 to question of Judaism (p. 30)

i. Introduction: the literary unity of chapters 2-4 (p. 30)

ii. Thematic survey of the 'messianic bridegroom' passages (p. 32)

1. John 2:1-11 (p. 32)

a. Thematic survey

b. Contributions to the relation of Jesus and Judaism

i. Instrumentality of Judaism to Jesus' work

ii. Necessity of a work peculiar to Jesus

2. John 3:22-36 (p. 36)

a. Thematic survey

b. Contributions to the relation of Jesus and Judaism

i. Contrast between origins of John and Jesus

ii. Contrast between ministries of John and Jesus

3. John 4:1-46 (p. 42)

a. Thematic survey

b. Contributions to the relation of Jesus and Judaism

i. Contrast between waters (4:10-14)

ii. Contrast between modes of worship (4:20-24) 


\section{iii. Contrast between laborers (4:34-38)}

iii. Summary of findings: Jesus and Judaism in the 'messianic bridegroom' passages (p.52)

1. Continuity
a. Law in positive light
b. Law as instrumental to Jesus
c. Common enterprise of the Law and Jesus

2. Discontinuity
a. Necessity of work peculiar to Jesus
b. Redemptive-historical turning point

3. Reason for superiority of Jesus over Judaism: different orders of being
a. John 3:31-36
b. John 4:22-24

iv. Conclusion: John 2-4 as a reprise of the "grace instead of grace" pattern of 1:1617 (p. 54)

1. 2:10 'good wine instead of good wine'

2. Baptist: 'baptism instead of baptism', 'light instead of light'

3. 4:22-23 'worship instead of worship'

\section{d. Sabbath Controversies (p. 55)}

e. Conclusion (p. 56)

\section{THE ROLE OF PASSOVER IN JOHN (p. 59)}

a. Introduction (p. 59)

b. Nationalistic expectations associated with Passover season (p. 59)

c. Passover in John: Jesus as pascal victim (p. 63)

d. Significance of Jesus' pascal sacrifice (p. 68)

i. Thematic contours of John 6: effecting the new exodus gathering of Israel through Jesus' giving of his flesh for the pascal meal (p. 68)

ii. Passover theme in John 6 (p. 69)

1. Opening Miracle

2. Discourse Section

iii. Isaianic New Exodus theme in John 6 (p. 73)

1. Opening Miracle 


\section{Discourse Section}

iv. Provision through Jesus' death (p. 81)

e. Symbolic meaning of the pascal meal (p. 83)

i. Jewish background (p. 83)

ii. John 6 (p. 91)

f. Conclusion (p. 93)

IV. THE ROLE OF TABERNACLES IN JOHN (p. 95)

a. Introduction (p. 95)

b. Isaiah 55: Jesus as source of eschatological waters of New Exodus (p. 97)

i. Allusion in John 7:32-37 (p. 97)

ii. Implication: Jesus, not the believer, is the source of living water (p. 100)

c. Citation at John 7:38: Meribah and eschatological Temple backgrounds (p. 104)

d. Analysis of $m$. Sukk. 4 and t. Sukk. 3: the altar ceremonies and the Meribah tradition (p. 106)

i. Water and Willow Ceremonies (p. 106)

ii. Association of Jesus with the altar (p. 109)

iii. Necessity of Jesus' death (analysis of ceremonies and sources) (p. 111)

1. Meribah tradition

2. Water ceremony

3. Willow ceremony

e. John 7 (p. 120)

f. Conclusion (p. 122)

V. THE ROLE OF DEDICATION IN JOHN (p. 124)

a. Introduction (p. 124)

i. Hanukkah background (p. 124)

ii. Contemporary scholarship (p. 125)

b. Exegesis of John 10:22-39 (p. 126)

c. Re-appraisal of 2 Maccabees (p. 130)

i. Currency in the first-century C.E. of the traditions in 2 Maccabees (p. 132)

ii. Contribution of 2 Maccabees to John 10 (p. 136)

d. Application to John 10 (p. 142)

e. Conclusion (p. 144) 
VI. CONCLUSION (p. 145)

a. Summary of findings (p. 145)

b. Conclusion (p. 146) 


\section{Chapter 1}

\section{Introduction}

\section{A. Introduction to the Question}

The following study seeks to understand the way in which the author of the Fourth Gospel has appropriated the symbolism, traditions and customs surrounding the named Jewish festivals in his presentation of Jesus. Few full-length treatments of this question have been offered by scholars and important facets of this background remain to be accounted for. The aim of this work, then, is to examine the use of the three Jewish festivals that appear in the Gospel narrative (Passover, Tabernacles, Dedication) both with a view toward correcting or nuancing earlier appraisals as necessary and shedding new light on the festivals from the evidence of the Jewish backgrounds in a way that provides for a fuller understanding of how each festival contributes to the theology of the Gospel.

The uniqueness of the annual pilgrimage feasts in John's Gospel becomes immediately evident from a simple comparison with the Synoptic Gospels. The term "feast" ('́optì) occurs 17 times in John which represents $68 \%$ of total New Testament usage. ${ }^{1}$ Similarly, 10 out of 29 or $34.5 \%$ of New Testament occurrences of "Passover" $(\pi \alpha \dot{\sigma} \sigma \alpha)$ appear in John. ${ }^{2}$ Unique among all New Testament books

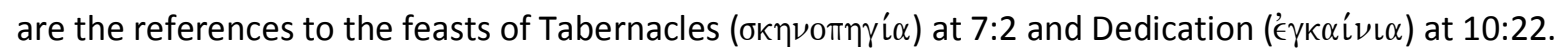
Clearly, John has a special interest in the Jewish festivals in his account of Jesus.

Furthermore, as a quick review of the above uses makes clear, the Jewish festivals play a far more integral role in the story of Jesus in John's Gospel than is the case in the Synoptic Gospels. Whereas the Synoptics make reference to Passover alone among the feasts, and that only during the Passion narrative (Luke 2 being the only exception), John portrays Jesus "going up to Jerusalem" over and again throughout his public ministry to attend not only Passover but Tabernacles and even Dedication (which was not a major pilgrimage feast). John, in other words, does not confine his use of

\footnotetext{
${ }^{1}$ The term occurs 7 times in the Synoptic Gospels (Matt 26:5; 27:15; Mark 14:2; 15:6; Luke 2:41, 42; 22:1) and once in Colossians (2:16). The occurrences in John are at 2:23; 4:45[2x]; 5:1; 6:4; 7:2, $8[2 \mathrm{x}], 10,11,14,37 ; 11: 56$; $12: 12,20 ; 13: 1,29$.

${ }^{2}$ The term occurs 16 times in the Synoptic Gospels (Matt 26:2, 17, 18, 19; Mark 14:1, 12 [2x], 14, 16; Luke 2:41; $22: 1,7,8,11,13,15)$ and once each in Acts (12:4), 1 Corinthians (5:7) and Hebrews $(11: 28)$. The occurrences in John (7 before and 3 within the passion narrative) are at $2: 13,23 ; 6: 4 ; 11: 55[2 x] ; 12: 1 ; 13: 1 ; 18: 28,39 ; 19: 14$.
} 
the Jewish feasts to the passion narrative but draws upon them repeatedly during the public ministry of Jesus.

Moreover, as many scholars recognize, John evidently appropriates select facets of the festal symbolism and traditions in shaping the narratives and discourses associated with the various feasts. To take one example, John 7-8 sets the controversy between Jesus and the Jewish leadership surrounding his identity and works during the festival of Tabernacles. Many commentators have recognized that the climactic declarations by Jesus at 7:37-38 and 8:12 allude, respectively, to the water and light ceremonies performed at the Temple throughout the seven-day feast. In this way, Jesus indicates that he fulfills the role of the Temple symbolically enacted in these ceremonies.

The role of the Jewish feasts in the Fourth Gospel has importance in its own right, of course. Beyond this, however, the question also bears upon the much-disputed matter of the relationship between Jesus and Judaism in the Fourth Gospel. Many Johannine scholars, today, speak in largely negative terms about Jesus' attitude toward contemporary Jewish customs and institutions. This view contributes to the widespread perception of the Gospel as the most anti-Semitic document in the New Testament canon. Other scholars advocate a more moderate interpretation of Judaism in the Fourth Gospel, pointing to the strikingly affirmative statement of 4:22 ("salvation is from the Jews") and insisting that a distinction be maintained between the often negative rhetoric directed toward "the Jews" and the attitude of Jesus toward Jewish religion. Owing to the relative lack of extended research on the feasts in the Gospel, the evidence of the festivals has not been adequately brought to bear upon the wider question of Judaism. For this reason, although a full-orbed treatment of the representation of Judaism in the Fourth Gospel lies outside the focus of this study, I will devote a chapter to situating my inquiry within this wider debate and then return to the question, albeit in brief fashion, at the conclusion of each subsequent chapter in order to suggest how my findings might contribute to the debate.

\section{B. Review of Previous Scholarship}

The unique predilection of the Fourth Evangelist for the Jewish festivals as vehicles for his presentation of Jesus has often been noticed but rarely probed in depth by students of the Gospel. I will review below the larger scale treatments of the feasts. First, however, I must survey the treatment given the feasts among the major commentaries.

The festal settings of the various discourses and narratives in the Fourth Gospel are commonly noted by commentators. However, owing to the limited space available to treat the backgrounds of the 
feasts, their full significance is often either largely under-appreciated or missed entirely. For example, many commentators note the structural significance of Passover for the Gospel as a whole, but few devote substantial space to drawing out the full symbolism of this feast for John's exposition of the cross. Mention of Passover at John 2:13 is routinely noted but its significance is confined to a temporal marker or to providing a structural frame with 2:23. ${ }^{3}$ More authors note the symbolic potential of the Passover settings in the Bread of life discourse and the Passion account. So, for example, the festal background in John 6 is often regarded as contributing to a new exodus theme or the establishment of a new Passover, namely the Eucharist, in the body and blood of Jesus. ${ }^{4}$ At several points in the Passion narrative allusions to the paschal sacrifice are detected which are thought to represent the crucifixion of Jesus as a paschal sacrifice. ${ }^{5}$ At none of these points, however, do commentators typically devote space to probing the Jewish traditions surrounding this feast. This inevitably impoverishes the reader's ability to discern with precision the fullness of the author's message in these several contexts.

\footnotetext{
${ }^{3}$ Raymond E. Brown, The Gospel According to John, 2 vols. (Garden City, N.Y: Doubleday \& Co, 1966, 1970), 123-125; Leon Morris, The Gospel According to John (New International Commentary on the New Testament. Rev. ed. Grand Rapids: Eerdmans, 1995), 169; Herman Ridderbos, The Gospel According to John: A Theological Commentary (Grand Rapids: Eerdmans, 1997), 114; D. A. Carson. The Gospel according to John (Leicester: Intervarsity, 1991), 176; Andreas J. Köstenberger, John (Grand Rapids, Mich.: Baker Academic, 2004), 104; Craig Keener, The Gospel of John: A Commentary. 2 vols. (Peabody, Mass: Hendrickson, 2003), 518; Francis J. Moloney, Belief in the Word: Reading the Fourth Gospel John 1-4 (Minneapolis: Fortress, 1993), 95. Gerald Borchert, John 1-11 (New American Commentary. Nashville, Tenn: Broadman \& Holman, 1996), 1.162, claims, "In this Gospel the cleansing of the Temple...is a sign that points to the pascal death and resurrection of Jesus (2:19)."

${ }^{4}$ See esp. E.C. Hoskyns, The Fourth Gospel (London: Faber and Faber, 1940), 281 (cf. 297-299), who regards the Passover setting as crucial for the themes of the chapter. Cf., also, B. F. Westcott, The Gospel According to St. John: The Greek Text with Introduction and Notes (London: J. Murray, 1908), 1.211; C. H. Dodd, The Interpretation of the Fourth Gospel (Cambridge: University Press, 1954), 333; Francis J. Moloney, Signs and Shadows: Reading John 5-12 (Minneapolis: Fortress, 1996), 38, 46-47, 55-59; Andrew T. Lincoln, The Gospel according to Saint John (Black's New Testament Commentaries; London: Continuum, 2005), 211, 234; Keener, 665, 688, 690; Brown, 1.245, 255, 286, 290; 291; Carson, 268; Köstenberger, 200; Borchert, 1.251, 271; Rudolf Schnackenburg, The Gospel According to St. John (Herder's Theological Commentary on the New Testament. London: Burns \& Oates, 1968-1982), 2.14; John Marsh, The Gospel of Saint John (Pelican New Testament Commentaries. Harmondsworth, Middlesex: Penguin Books, 1968), 283; Jerome H. Neyrey, The Gospel of John (New Cambridge Bible Commentary, Cambridge: Cambridge University Press, 2006), 116 (in John 6, "Passover is not just calendar time, but symbolic time."). Morris, John, 303, and Ridderbos, John, 226, represent a minority who find little or no importance in the Passover setting for the thematic content of John 6.

${ }^{5}$ Keener, John, 1100-1103, among others, argues that the Evangelist has rearranged the Passion chronology found in the Synoptic tradition to highlight the Passover symbolism. Allusions to Passover are also detected at 19:14 (e.g., Keener, John, 1129-1131; Francis J. Moloney, Glory not Dishonour: Reading John 13-21 (Minneapolis: Fortress, 1998), 114; Brown, John, 833; Borchert, John, 2.258), 19:29 (e.g., Keener, John, 1147; Moloney, Glory, 145-146; Brown, John, 930; Lincoln, John, 478; Hoskyns, John, 531) and in the mention of the unbroken bones (e.g., Keener, John, 1153, 1155-1156; Brown, John, 952-953; Morris, John, 727 (tentatively); Lincoln, John, 481; Barnabas Lindars, The Gospel of John (New Century Bible. London: Oliphants, 1972), 590; Carson, John, 627; C. K. Barrett, The Gospel According to St. John: An Introduction with Commentary and Notes on the Greek Text (2nd ed. Philadelphia: Westminster Press, 1978), 557; Köstenberger, John, 553; Hoskyns, John, 533; Borchert, John, 2.278). Here, again, Ridderbos is representative of the few who see no great significance in the Passover setting (cf. John, $589,606,617$ n.166, 622-623).
} 
The same pattern obtains with the feasts of Tabernacles and Dedication. The former retains the attention of commentators to a greater extent, perhaps because the customs that accompany the festival are more colorful and elaborate. ${ }^{6}$ The feast of Tabernacles may also receive the most background study of all three feasts, owing in part to the rich and suggestive descriptions supplied by a handful of sources from the second Temple and early rabbinic periods. Even here, however, few commentators devote substantial space to a consideration of the background sources, relying, instead, on the surveys and conclusions of a few earlier authors. Thus, commentaries on John's Gospel routinely observe the prominence of the feasts in specific contexts and in the Gospel as a whole but rarely provide the depth of insight into the phenomenon that seems warranted by this distinctive feature of the Fourth Gospel.

Besides the brief observations offered by many commentators, there have been very few extended treatments of the matter. One exception is the monograph by Gale A. Yee, Jewish Feasts in John's Gospel. ${ }^{7}$ Yee's work provides a helpful introduction to the topic. However, as it is aimed at a general audience, it does not give sustained attention to the many technical and background issues necessary for drawing out the full picture of John's use of the feasts. Her discussion of the Tabernacles narrative, for example, devotes merely three pages to the Mishnah and almost no space at all to other Rabbinic evidence for the celebration of the festival. ${ }^{8}$ A more thorough account of this festival must supply a detailed analysis of the treatment of the water ceremony in Tosephta Sukkah 3, for example, which makes an important contribution to the thematic and symbolic background of John 7 . In similar

\footnotetext{
${ }^{6}$ See discussions in Westcott, John, 1.277; 2.2; Keener, John, 722-730, 739, 742, 744, 758 (though he is reluctant to limit the light imagery to this background); Moloney, Signs, 84-93; Brown, John, 326-329, 343-344; Lincoln, John, 254-257, 264-265; Carson, John, 321-328, 337; Köstenberger, John, 240; Ben Witherington, John's Wisdom: A Commentary on the Fourth Gospel (Louisville: Westminster John Knox, 1995), 173; Hoskyns, John, 320-321; Borchert, John, 1.290, 295-296; Neyrey, John, 147, 153; Klaus Wengst, Das Johannesevangelium 1, Teilband, Kapitel 1-10, (Theologischer Kommentar zum Neuen Testament, Stuttgart: Verlag W. Kohlhammer, 2000), 292; Christian Dietzfelbinger, Das Evangelium nach Johannes (Zürcher Bibelkommentare: NT; Zürich: Theologischer Verlag, 2001), 226; Hartwig Thyen, Das Johannesevangelium (Handbuch zum Neuen Testament (HNT); Tübingen: Mohr Siebeck, 2004), 403; Schnackenburg, John, 2.155. Morris, John, 374, 388, once again represents the small minority of commentators who find little basis for an allusion to the ceremonies of Tabernacles. While the list of scholars who see no symbolic importance in the feast of Dedication for John 10:22-39 is lengthier (cf. Ridderbos, John, 367; Morris, John, 460; Neyrey, John, 186 n. 291; J. H. Bernard, A Critical and Exegetical Commentary on the Gospel According to St. John (The International Critical Commentary. Edinburgh: Clark, 1928), 342-343; Schnackenburg, 2.305; Barrett, John, 379; and note the silence of Lindars, John, Dietzfelbinger, Johannes, Wengst, Johannesevangelium, and L. Schenke, Johannes: Kommentar (Dusseldorf, 1998)), many discern allusions to the festival in the word about the consecration of Jesus in 10:36 and even the charge of blasphemy in 10:33. See Keener, John, 822, 827, 830; Moloney, Signs, 148-150; Brown, John, 400, 411; Lincoln, John, 309; Carson, John, 399; Köstenberger, John, 316; Hoskyns, John, 385, 392; Marsh, John, 407; George R. Beasley-Murray, John (Word Biblical Commentary, v.36. Waco, Tex: Word Books, 1987), 177.

${ }^{7}$ Wilmington, Delaware: Michael Glazier, 1989.

${ }^{8}$ See chapter 3 .
} 
fashion, she provides a helpful sketch of the historical background of the festival of Dedication but fails to give more than passing attention to the evidence of 2 Maccabees, a work ostensibly intended to promote the celebration of the festival among diaspora Jews. ${ }^{9}$ Though helpful as a general introduction to the question of the festivals in the Fourth Gospel, Yee's work leaves the way open for a more detailed consideration of the subject.

More recently, Michael A. Daise has proposed a new understanding of the function of the feasts in John. ${ }^{10}$ He argues, "in an earlier stage of the Fourth Gospel's development (when chapters 5 and 6 were reversed), the feasts fundamentally functioned to accentuate Jesus' 'hour' by quantifying its immanence till it arrived." ${ }^{11}$ His interpretation is based upon two basic ideas. First, the Passover of John 6:4 is the "second Passover" of Num 9:9-14. This is evident, he argues, from the mention of the barley loaves at John 6:9 which could not legally have been used for non-cultic purposes until the firstfruits of the barley harvest had been offered in the Temple, and this did not happen until the day after the Sabbath following the first Passover (cf. Lev 23:11-15). Thus, if Passover was said to be near (6:4) and yet barley was being used for non-cultic purposes then it must have been the second Passover which took place in the month of "lyyar. ${ }^{12}$ The second idea upon which he bases his reading is that John 5-6 must have been reversed in an earlier version of the Gospel. ${ }^{13}$ These twin conclusions lead Daise to view the Gospel at an earlier stage of its redaction as having ordered the feasts in a perfect chronological schema such that the festal cycle from John 2-12 spans a single year (Passover, second Passover, the unamned feast, Tabernacles, Dedication and Passover) and this cycle highlights the advance of Jesus' hour from "not yet" in John 2 to its arrival in John 12.

The aim of Daise's work is primarily to elucidate the contribution of the feasts to the structuring of the Fourth Gospel, or more precisely, an earlier version of the Gospel. ${ }^{14}$ For this reason, he devotes little attention to the symbolic and traditional background of the respective feasts and how these factors contributed to the shape of the narratives and discourses set against the feasts. ${ }^{15} \mathrm{His}$

\footnotetext{
${ }^{9}$ See chapter 4 .

${ }^{10}$ See Feasts in John: Jewish Festivals and Jesus' "Hour" in the Fourth Gospel (Wissenschaftliche Untersuchungen Zum Neuen Testament, 2.229; Tübingen: Mohr Siebeck, 2007).

${ }^{11}$ Feasts, 5.

${ }^{12}$ See Feasts, ch. 4, for elaboration and argumentation.

${ }^{13}$ For this he leans heavily upon the work of earlier scholars. See discussion in Feasts, 12-15.

${ }^{14} \mathrm{He}$ recognizes that his interpretation bears almost exclusively for understanding this earlier edition of the Gospel since the final reconfiguration of chapters 5 and 6 dramatically reduces the force of the chronological schema he proposes (Feasts, 172). The recent review by Glen Balfour, though largely laudatory, nevertheless notes the unlikelihood that an early reader of the Fourth Gospel in its current form could have discerned the meaning elucidated by Daise. See the review in Journal for the Study of the New Testament, 30.5 (2008) 69-70.

${ }^{15}$ See Feasts, ch. 2, which treats the structural position of the each feast but almost entirely omits any treatment of their symbolic and traditional value in contemporary Judaism.
} 
conclusions, therefore, do not bear directly upon the present study since I aim to elucidate the thematic function of the feasts in the Fourth Gospel in its current form. Indeed, Daise concludes his work by noting that the reconfiguration of the chronology of the Gospel that has diminished the earlier structural significance of the feasts (as he interprets them) leads naturally to the question of whether the feasts function in more thematic fashion in the final form of the Gospel. That is, the conclusions of Daise's work highlight the need for the very line of inquiry I wish to pursue. ${ }^{16}$

A third, recent study also merits attention for its proposal concerning the function of the feasts in the Fourth Gospel. In her 2005 monograph on Passover Christine Schlund surveys the symbolic significance of the festival in Jewish tradition represented in the LXX, Jubilees, Ezekiel the Tragedian, Wisdom of Solomon, Philo and Josephus before turning to its role in John. ${ }^{17}$ Her investigation of the Jewish sources leads to the conclusion that the festival bears two primary lines of significance. ${ }^{18}$ In the first place, Jubilees, Ezekiel the Tragedian and Josephus are among the sources which evince a focus on the apotropaic value of the yearly Passover celebration. ${ }^{19}$ In this view, the faithful observance of the festival secures divine protection for the people of God in the coming year. The second area of symbolism revolves around community identity. Sources such as Josephus, Philo and Jubilees indicate that the feast of Passover was an important instrument for confirming and strengthening community identity and solidarity. ${ }^{20}$ She concludes,

Das Pesach verifigte also in frühjüdischer Zeit über ein weitgefächertes Interpretationspotential: Es verkörperte Schutz und Bewahrung vor Verderben bringenden Mächten und die Uberwindung des Todes im Moment der Konfrontation genauso wie die Vergewisserung des rechten Gottesverhältnisses und die Konstitution bzw. Bestärkung der Identität des Gottesvolkes. ${ }^{21}$

Working from these conclusions about the Jewish background of the festival, Schlund turns to the use of Passover symbolism in the Gospel of John. Beginning with the passion account, Schlund finds both the coordination of Jesus' death with the slaughter of the lambs in the Temple as well as the

\footnotetext{
${ }^{16}$ Feasts, 172-173.

17 "Kein Knochen soll gebrochen werden" : Studien zu Bedeutung und Funktion des Pesachfests in Texten des frühen Judentums und im Johannesevangelium (Wissenschaftliche Monographien zum Alten und Neuen Testament;

Neukirchen-Vluyn: Neukirchener Verlag, 2005). She also devotes some space to consideration of Passover in other New Testament documents.

${ }^{18}$ Kein, 112-114.

${ }^{19}$ These sources are treated at length in Kein, chapters 3-5.

${ }^{20}$ Philo is treated in Kein, chapter 3.

${ }^{21}$ Schlund, Kein, 113.
} 
Scripture citation at John 19:36 to be likely allusions to Passover (the latter by way of Exod 12:46). ${ }^{22}$ She stops short, however, of finding in these allusions a clear indication of the meaning of Jesus' death. Instead, she discerns the meaning of Jesus death as paschal sacrifice in the main body of the Johannine narrative prior to the passion narrative. Specifically, her investigation draws three elements into focus: "Sammlung, Überwindung und Reinheit". ${ }^{23}$ The last, the association of Passover with purity concerns, emerges from John 13. Set expressly on the eve of Passover, Jesus washes the disciples' feet to purify them ritually for the Passover meal, the meal he will shortly provide by his death. Consistent with the Jewish evidence she surveys in the earlier sections of her work she does not believe that John represents the paschal sacrifice of Jesus as effecting cleansing from sin.

The second element of John's Passover symbolism, Überwindung, is most evident in passages like John 12:27-33 and 17:15 where Jesus connects his death with the deliverance and protection from the "evil one". This "apotropaic" dimension of Passover symbolism, she points out, is common in Jewish literature, especially Jubilees. ${ }^{24}$

Finally, within the context of the triumphal entry into Jerusalem and the coming of the Passover celebration, the episode of the coming of the Greeks to Jesus (12:20-21) suggests to Schlund the "Sammlung" or "Gemeindkonstitution" dimension of John's Passover symbolism. ${ }^{25}$ Her treatment of this question, though suggestive, is striking for the short space accorded to John 6 , the central Passover context in the Gospel and arguably the context where the import of the symbolism is most clearly elucidated in the Gospel. ${ }^{26}$ In my judgement, this Gemeindkonstitution dimension of John's Passover symbolism is the most promising and under-appreciated facet of the whole question. It is, therefore, all the more unfortunate that the matter receives so little attention from Schlund. In my treatment of Passover below I hope to fill precisely this lacuna. Indeed, the results of my work may be seen to fit quite neatly with the conclusion of Schlund's work on other sections of the Gospel.

Apart from Yee, Daise, and Schlund, most extended discussions of the Jewish feasts in John appear as chapters in works devoted to the theme of the Temple in John. For example, Mary Coloe, in God Dwells with Us, reads the Temple theme in John against the backdrop of the destruction of the Temple in A.D. 70, an event she regards as "a major turning point" not only for orthodox Jews but for

\footnotetext{
${ }^{22}$ Kein, 120-129.

${ }^{23}$ See Kein, 142-165.

${ }^{24}$ Kein, 151-159, esp. 155-156.

${ }^{25}$ Kein, 142-151.

${ }^{26}$ She devotes barely two pages to John 6 , focusing primarily on a parallel with Joshua 5 .
} 
Christians as well, precipitating among both groups "a major religious struggle for self-identity." ${ }^{27}$ This identity-crisis became especially acute for the Christians when they found themselves removed from their synagogues. All of this raised a "painful question - how could they maintain their Jewish traditions, especially their rich cultic traditions, and maintain their new faith in Jesus?" Thus, "the Fourth Gospel is the written record of one Christian community's response to this question." 28 With respect to the role of the feasts in John, she believes Jesus appropriates to himself the cultic symbols of bread, water, light and sacred place. For example, in her treatment of the feast of Tabernacles Coloe argues that the "last and greatest day" of the feast (John 7:37) denotes the $8^{\text {th }}$ day when the water and light ceremonies had ceased. It is against the backdrop of this absence of water and light that Jesus makes his twin Christological claims (7:37;8:12). Coloe views this as part of a larger pattern across the Gospel which she dubs, "the paradox of presence in absence." ${ }^{29}$ In the absence of the Temple and its associated institutions and traditions following A.D. 70 Jesus provides the needed means and location of worship. ${ }^{30}$

Nevertheless, Coloe does not give adequate attention to important dimensions of John's use of the festivals. For example, Passover receives attention only in connection with Jesus' association with the pascal victims in the passion narrative. ${ }^{31}$ No account at all is made of the theme of the Passover meal nor is space given to consideration of contemporary associations linked to the festival. She devotes a full chapter to Tabernacles in John 7-8, but here again she neglects the important background of the Tosephta and so overlooks any contribution this text makes to Jesus' statements in this context. ${ }^{32}$ In similar fashion, her treatment of Dedication suffers for lack of engagement with important background material (especially 2 Maccabees). ${ }^{33}$

\footnotetext{
${ }^{27}$ See God Dwells with Us: Temple Symbolism in the Fourth Gospel (Collegeville, Minnesota: Liturgical Press, 2001) 2.

${ }^{28}$ Dwells, 2.

${ }^{29}$ Dwells, 130.

${ }^{30}$ This is a helpful perspective from which to begin her inquiry, and one which, on many occasions, is fleshed out by use of careful language to describe the relationship between Jesus and Judaism. For example, she says, "The traditions and institutions of Israel were valid but incomplete gifts; in the life of Jesus something new is being offered which brings to perfection the former gifts to Israel" (Dwells, 205). Elsewhere she says, "A consistent Johannine theme has been the presentation of Jesus as the one who brings to completion the rituals and symbols of Israel's cult" (Dwells, 62). At many points her view approximates the one I will argue for below. See, e.g., the concluding comments in my next chapter.

${ }^{31}$ Dwells, 190-196.

${ }^{32}$ See chapter 6 . On pages 131-132 she comments briefly on the relevant section of the Tosephta, relying heavily on the work of Pierre Gelot.

${ }^{33}$ See chapter 7.
} 
Alan Kerr's treatment of the Temple theme in John also devotes substantial space to the feasts. ${ }^{34}$ Largely following conventional lines of interpretation, Kerr views the feasts as finding their fulfillment and replacement in Jesus. At many points, his discussion is helpful ${ }^{35}$ though he adopts a more confrontational view of the relationship between Jesus and the festivals than Coloe. This is clearest in his suggestion that the unnamed feast in John 5 represents all the feasts and that the setting of sickness and disease represents "a picture of Judaism (including the festivals) in its weakness and impotence." In similar fashion, Passover is "superceded" by Jesus. He summarizes, "the 'flesh' of the Jewish Passover is of no avail; it is spiritually ingested Jesus...that brings life." This negative appraisal of the Jewish institutions in John runs throughout Kerr's assessment of the Jewish feasts and becomes explicit in his concluding reflections. He comments, "Jesus seemed to have little respect for the festivals. He scarcely attended them, and when he did go to the Tabernacles festival he hijacked it for his own purposes...There seems to be an underlying critique of the festivals running through chs. 5-11 of the Gospel." ${ }^{\prime 36}$

In my next chapter I will take up the matter of the general picture of Judaism in John and there I will discuss John's representation of the limitations inherent in Jewish institutions. Notwithstanding the presence of such limitations, I will argue that language such as Kerr employs is unduly bleak and misrepresents the portrait of Judaism in the Fourth Gospel. ${ }^{37}$ Moreover, I will argue in my treatments of the individual festivals that so far from rejecting or belittling them Jesus holds them in the highest regard and frames the salvation he brings in terms of the fulfillment of the highest aspirations of these very festivals. The significance of John's use of the feasts lies not in Jesus' replacement of failed or impotent institutions, but rather in his entry into those perfectly valid customs to bring them to the fullness of their purposes.

\section{Method and Statement of Task}

\footnotetext{
${ }^{34}$ The Temple of Jesus' Body: The Temple Theme in the Gospel of John (Journal for the Study of the New Testament Supplement Series, v.220; Sheffield: Sheffield University Press, 2002) ch. 7.

${ }^{35}$ Cf., e.g., his treatment of John 6 and the question of the background in the Jewish Passover Haggadah on pages 211-215.

36 Temple, 266-267.

${ }^{37}$ It is more than a little odd that Jesus could be said "to have little respect for the festivals" and to have "scarcely attended them" when John devotes so much attention to the Jewish festal calendar. and has Jesus attending two Passovers in Jerusalem, teaching at a synagogue during a third, and attending two other feasts in Jerusalem (again, contrast the Synoptic Gospels where Jesus attends only one festival, and only at the very end of his ministry). Kerr's appraisal is also belied by the application to Jesus of various symbolic elements from the feasts (pascal victim, 1:29; Passover meal, 6:53; water, 7:37; light, 8:12; altar, 10:36).
} 
In what follows, then, I will investigate the feasts of Passover, Tabernacles and Dedication in John with a view toward providing a clearer picture of how John appropriates the symbolism and traditions surrounding these feasts in his presentation of Jesus. In this way I will also seek to contribute on a modest scale to the wider question of Jesus and Judaism in the Fourth Gospel.

I will proceed by looking closely at the several contexts in John's Gospel that are set against the named festivals in order to discern the emphasis or emphases of the author. I will make a focused investigation into the background of each feast, including the customs, traditions, and expectations surrounding it. The goal will not be to provide a full-scale exposition of each feast, but rather to detect points of relevance in the ancient sources for shedding light on the use of the feast made by the author of the Fourth Gospel. Without denying the influence of non-Jewish categories of thought, the Jewish nature of the festivals in question will require that I attend principally to Jewish sources. ${ }^{38}$ The bulk of my investigation into the Jewish background of the feasts will be based on sources from the second Temple period. In the case of Tabernacles, however, I will devote considerable space to the Mishnah and Tosephta. These documents post-date the ministry of Jesus and the composition of John's Gospel, of course. Nevertheless, a growing body of scholarship has argued for the value of these early rabbinic works for historical inquiry into the beliefs, practices and traditions in the pre-70 A.D. period. ${ }^{39}$ I will, therefore, scrutinize the historical reliability of the relevant traditions from the Mishnah and Tosephta before turning to consider their significance for reading John 7-8.

\footnotetext{
${ }^{38}$ For helpful surveys of trends in scholarly assessment of the primary influences upon the Gospel (Gnostic, Old Testament, Rabbinic, Hellenistic, etc.) see esp. Robert Kysar, "Historical Puzzles in John," in Voyages with John: Charting the Fourth Gospel, edited by Robert Kysar (Waco, TX: Baylor University Press, 2005), 77-107.

${ }^{39}$ Cf. discussion in Keener, John, 185-194. See also below, chapter 4, in my discussion of the water and willow ceremonies at the feast of Tabernacles and the literature there cited, especially the works of Baumgarten who adduces evidence from newly discovered documents from Qumran to vindicate select historical claims in early rabbinic sources.
} 


\section{Chapter 2}

\section{The Role and Perception of Judaism in John}

\section{A. Introduction: Judaism in John}

The question of how the Fourth Gospel represents Judaism in relation to Jesus and the salvation he brings has garnered enormous attention in recent decades. ${ }^{40}$ In the wake of the horrors of the Holocaust interpreters of John's Gospel have wrestled in a new and more urgent way with the portrayal of Jesus as it relates to "the Jews" and their religious institutions. The subject has profited by reflection from multiple angles including the use of the expression "the Jews", ${ }^{41}$ the use of Scripture citations, ${ }^{42}$ the language of "law", 43 the legal or forensic dimensions of official persecution of Jesus, ${ }^{44}$ and Jesus' attitude toward various Jewish institutions such as the Temple, the festivals and the Sabbath. ${ }^{45}$ The burden of this thesis, of course, is the elucidation specifically of John's use of the symbolism and

\footnotetext{
${ }^{40}$ The literature is vast. Particularly worthy of note as a point of entry into the discussions is the collection of essays on the various facets of the subject in Reimund Bieringer, Didier Pollefeyt and Frèdèrique VandecasteeleVanneuville, eds., Anti-Judaism and the Fourth Gospel (Louisville: Westminster John Knox, 2001). Also worthy of special note is the recent, wide-ranging work of Johannes Beutler, Judaism and the Jews in the Gospel of John (Subsidia Biblica; Roma: Editrice Pontificio Istituto Biblico, 2006), and the sociological study of Raimo Hakola, Identity Matters: John, the Jews and Jewishness (Supplements to Novum Testamentum; Leiden: Brill, 2005).

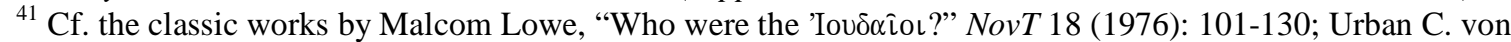
Wahlde, “The Johannine 'Jews': A Critical Survey," NTS 28 (1982) 33-60; idem., "“The Jews' in the Gospel of John: fifteen years of research (1983-1998)." ETL 76 (2000): 30-55; John Ashton, "The Identity and Function of the Ioudaioi in the Fourth Gospel." NovT 27 (1985): 40-75; and more recently by Sara J. Tanzer, "The problematic portrayal of 'the Jews' and Judaism in the gospel of John: implications for Jewish-Christian relations," in Contesting texts: Jews and Christians in conversation about the Bible, (ed. Melody D. Knowles, Esther Menn, John T. Pawlikowski, Timothy J. Sandoval; Minneapolis: Fortress Press, 2007) 103-118, 200-206; and esp. Lars Kierspel, The Jews and the World in the Fourth Gospel: Parallelism, Function, and Context (Wissenschaftliche Untersuchungen Zum Neuen Testament; Tübingen: Mohr, 2006).

${ }^{42}$ See esp. C. K. Barrett, "The Old Testament in the Fourth Gospel,” JTS 48 (1947): 155-169; C.A. Evans, "On the Quotation Formulas in the Fourth Gospel," BZ 26 (1982): 79-83; D. A. Carson, "John and the Johannine Epistles," in It is Written: Scripture Citing Scripture. Essays in Honor of Barnabas Lindars, SSF (ed. D.A. Carson and H.G.M. Williamson; Cambridge: Cambridge University Press, 1988) 245-264; Johannes Beutler, "The Use of 'Scripture' in the Gospel of John," in Exploring the Gospel of John: In Honor of D. Moody Smith (ed. R. Alan Culpepper and C. Clifton Black; Louisville, Ky.: Westminster John Knox, 1996) 147-162; Menken, M. J. J., "Observations on the significance of the Old Testament in the fourth gospel," in Theology and Christology in the Fourth Gospel (ed. Gilbert van Belle, J.G. Van der Watt, P.J. Maritz; Leuven: Leuven University Press, 2005), 155-175.

${ }^{43}$ Esp. Severino Pancaro, The Law in the Fourth Gospel: The Torah and the Gospel Moses and Jesus, Judaism and Christianity According to John (Supplements to Novum Testamentum, 42. Leiden: Brill, 1975).

${ }^{44}$ E.g., Rodney A. Whitacre, Johannine Polemic: The Role of Tradition and Theology (Chico: Scholars Press, 1982).

${ }^{45}$ Among the many works devoted to this issue, cf. Coloe, Dwells; Kerr, Temple; Paul M. Hoskins, Jesus as the Fulfillment of the Temple in the Gospel of John (Paternoster Biblical Monographs; Milton Keynes : Paternoster, 2006); Stephen T. Um, The Theme of Temple Christology in John's Gospel (Library of New Testament Studies; London: T \& T Clark, 2006).
} 
customs surrounding the Temple festivals. It is unnecessary, therefore, to address these many important questions in detail. It will be useful, however, to address one particular facet of this debate with a view toward laying the groundwork for my reading of the festivals in the following chapters. Specifically, I wish to suggest that there is important evidence in the narratives of John 2-4 for the relationship between Jesus and Judaism which has not been adequately appreciated in contemporary discussions. Indeed, apart from (often brief) discussions of the stone jars in 2:6 and the "replacement" of the Temple in 2:18-21, these chapters have been very largely ignored. I wish to help restore balance, at this point, by drawing attention to the theme of the messianic bridegroom that recurs throughout these chapters and to the interaction of this theme with various institutions of Judaism. I will begin with

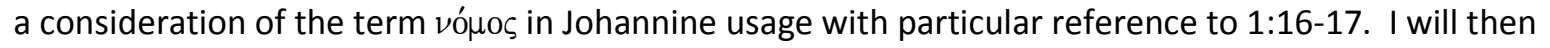
turn to a thematic analysis of John 2-4.

\section{B. Law in John}

The term vómos occurs fourteen times in the Fourth Gospel (including the periscope of the adulterer). ${ }^{46}$ The primary reference of the term is to the writings of Moses $(1: 17,45 ; 5: 46 ; 7: 19)$ though "Law" can also designate the entire Old Testament as in citations from the Psalms or prophets ascribed to "the law" (cf. 10:34; 12:34; 15:25). Among the functions of the Law in John is the governance of covenant praxis, including matters legal, ethical and cultic. Thus, for example, the Law lays out the parameters for prosecution of a lawbreaker $(7: 51 ; 8:[5], 17 ; 18: 31 ; 19: 7)$, prohibits murder $(7: 19)$ and prescribes circumcision (7:23). Though never expressly mentioned, the observance of Temple worship, particularly the feasts, originates in the law as implied in the discussion with the Samaritan woman about proper Temple worship (4:20-22).

A second function of the law, in addition to governing covenant praxis, is to testify to Jesus. First Philip (1:45) and later Jesus himself (5:46) claim that the law is 'about' Jesus. Moreover, Jesus can cite Psalms or prophets as instances of "the Law" finding fulfillment in his life experience (cf. 12:34; 15:25). The Evangelist even seems to suggest at 19:7 that the Law finds fulfillment in Jesus' death. ${ }^{47}$ John's use of the Law, however, extends well beyond these several occurrences of the term vónos. He portrays Jesus in relation to the Law by use of contemporary symbols for the Law such as

\footnotetext{
${ }^{46}$ John 1:17, 45; 7:19 [2x], 23, 49, 51; 8:5, 17; 10:34; 12:34; 15:25; 18:31; $19: 7$ [2x]. For a similar analysis to what follows, see Pancaro, Law, 515.

${ }^{47}$ See esp. Pancaro, Law, 326-363; cf. Keener, John, 1125.
} 
water, light, and manna. ${ }^{48} \mathrm{He}$ also portrays Jesus in typological relationship to events from Israel's history narrated in the law, especially from the wilderness period. ${ }^{49}$ At several points in John's Gospel Jesus' relation to the Law is conveyed by describing his encounter with specific practices or customs of the Law such as the Sabbath, circumcision, a Jewish wedding, and annual festivals. Notably, many of the symbols and customs with which Jesus interacts post-date the Mosaic Torah and even the entire Old Testament Scripture. John evidently includes within the realm of the "Law" practices, beliefs and symbols which were Jewish innovations from the mid- to late-second Temple period. ${ }^{50}$ In a word, the Law is co-extensive with what scholars today refer to as Judaism. ${ }^{51}$

To summarize my discussion so far, John uses the term "Law" in a variety of ways. It designates principally the Mosaic Torah, though it can also encompass the Old Testament Scriptures as a whole. The functions of the law are to govern Jewish life in ethical, legal and cultic matters, and to witness to the Messiah. In this way, not only the Mosaic Law, but the Scriptures as a whole and even later Jewish innovations in practice and belief prepare for Jesus. They do this by means of express prophecy as well as by the instrumentality of the system of worship (Sabbaths, festivals, sacrifices) and even by the very history of the people of Israel in the form of typological fulfillment.

Of particular concern to the question of the Law and Judaism in the Fourth Gospel is the first mention of the Law in the Gospel at John 1:17. The verse declares, "For the Law was given through Moses; grace and truth came through Jesus Christ." This text will be given special attention because of its programmatic significance for the role of the law in the Fourth Gospel. An extended examination of this verse will further refine and sharpen the characterization of the Law provided above.

John 1:17 forms an integral part of verses $14-18$ and cannot be read apart from consideration of the section as a whole. John 1:14-18 portrays the significance of the incarnation of the Word against the

\footnotetext{
${ }^{48}$ On this, see the treatment by Thomas Francis Glasson, Moses in the Fourth Gospel (Studies in Biblical Theology. London: SCM Press, 1963), 86-94; and Pancaro, Law, 452-487.

${ }^{49}$ Cf. e.g. John 6:5-14, 26-35 which draws upon Ex 16 and Num 11 in order to cast Jesus as the latter-day food for the life of the people. See, again, Glasson, Moses, 45-47; and, now, Susan Hylen, Allusion and Meaning in John 6 (Beihefte Zur Zeitschrift Für Die Neutestamentliche Wissenschaft, 137. Berlin: Walter de Gruyter, 2005), 120-130, $135-145$.

${ }^{50} \mathrm{Cf}$. the use of the traditions surrounding Hanukkah at the climax of Jesus' public ministry in John 10:22-39. Hanukkah, of course, originated in the mid-second century B.C.E.

${ }_{51}$ Elizabeth Harris, Prologue and Gospel: The Theology of the Fourth Evangelist (Journal for the Study of the New Testament Supplement Series, 107. Sheffield: Sheffield Academic Press, 1994), 76-77, sums up: “Moses and the Law' is to be understood to refer not only to the Decalogue and Pentateuchal ordinances, but also to the teaching of authorized successors of Moses, who expand and interpret the law for the changing needs of Jews in their religion. By the time of the Evangelist Moses (and the Law) could be a shorthand for the entire system and teaching of Judaism in its manifold varieties...."
} 
backdrop of the revelation of the Law to Moses at Sinai in Exodus 33-34 where God manifests his glorious character before Moses. ${ }^{52}$ Besides the express mention of the giving of the Law to Moses at 1:17, this allusion is evident in the presence of several terms from the Exodus account of the giving of the Law at Sinai. In particular, the terms "dwell", "glory", "full of grace and truth" together with the theme of seeing the glory of God put beyond doubt that John aimed to juxtapose the incarnation of Jesus with the revelation of the glory of God to Moses at Sinai.

The language of dwelling likely evokes the Sinai narrative generally (esp. Exod 25-40). Though

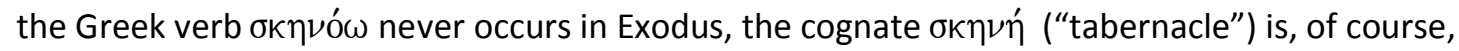
abundant. More importantly, the theme of the dwelling of God in the midst of his people dominates the narrative in which the Lord instructs Moses to build a Tabernacle "so that I may dwell in their midst." ${ }^{15}$ This dwelling of God with his people was the very purpose for which he brought them out of Egypt: "I will dwell among the people of Israel and will be their God. And they shall know that I am the LORD their God, who brought them out of the land of Egypt that I might dwell among them." ${ }^{54}$ In the episode of the golden calf this divine dwelling becomes central to the dilemma created by the people's sin: should the presence of God remain in the midst of the camp it would form a grave threat to their safety (Exod 33:3, 5). The following exchange between Moses and God grapples with this dilemma (Exod 33:12-17) and culminates in the theophany of Exod 34:6 in which God declares "his name". In context, the declaration of the gracious, forgiving character of God serves to assure Moses that the restoration of

\footnotetext{
${ }^{52}$ Among the many scholars who discern the Exodus background, here, see esp. Marie-Joseph Lagrange, Évangile selon saint Jean (Études bibliques; 5. éd; Paris: J. Gabalda, 1936), 23; Marie Emile Boismard, St. John's Prologue, (Translated by Carisbrooke Dominicans. London: Blackfriars, 1957), 135-145; Craig A. Evans, Word and Glory: On the Exegetical and Theological Background of John's Prologue (Journal for the Study of the New Testament, 89, Supplement series. Sheffield: JSOT Press, 1993), 79-83; Kerr, Temple, 117-126; Keener, John, 410-412; Craig R. Koester, The Dwelling of God: The Tabernacle in the Old Testament, Intertestamental Jewish Literature and the Old Testament (Catholic Biblical Quarterly Monograph Series, 22. Washington, D.C: Catholic Biblical Association of America, 1989), 102-105. Cf. Beasley-Murray, John, 14-15; Brown, John, 36; Hoskyns, John, 144; Lindars, John, 95, 98; Carson, John, 129; Z. Hodges, "Grace after Grace - John 1:16," BibSac, 135 (1978) 41; Anthony Tyrrell Hanson, "John I. 14-18 and Exodus XXXIV," NTS 23 (1976): 90-101; Henry Mowvley, "John 1:14-18 in the Light of Exodus 33:7-34:35," ExpT 95 (1984): 135-137.

${ }^{53}$ Exodus 25:8. Hebrew:

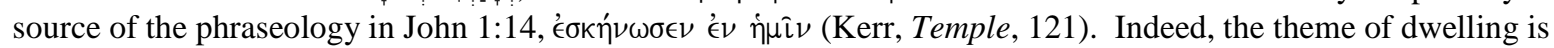
more clearly dominant in the Hebrew text than the LXX which never renders the Hebrew verb שָָׁ by a Greek verb

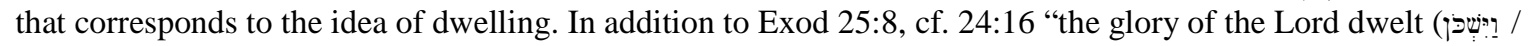

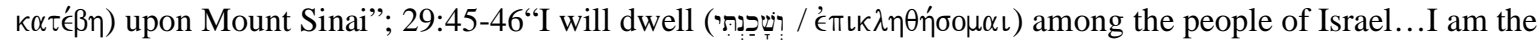

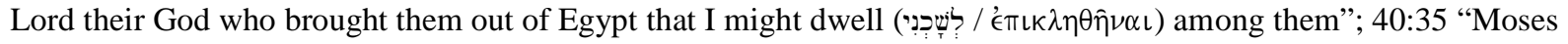

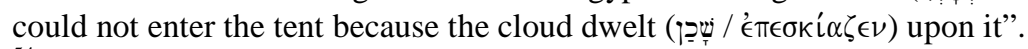

${ }^{54}$ Exodus 29:45-46.
} 
God's presence among the people will be for their blessing and not their undoing. ${ }^{55}$ Importantly, it is precisely this climactic passage (Ex 34:6) to which John alludes in 1:14. By this means he indicates that Jesus is the new dwelling place of God. ${ }^{56}$

Like "dwell", the use of "glory" in John 1:14 probably evokes the Sinai narrative where "the glory of the Lord dwelt (יפְי) on Mount Sinai" (Exod 24:16). The tabernacle was sanctified by the glory of God (29:43) and when Moses completed its construction the glory of God so filled the tent that Moses could not enter it (40:34-35). The request of Moses to see the glory of God (33:18) probably represents the primary background to John's declaration, "we have seen his glory" (John 1:14), while God's refusal to let Moses see his face (Exod 33:20, 23) likely stands behind John's statement, "no one has ever seen God" (John 1:18). "What could not be granted to Israel or the elders or even to Moses is now granted in the fullness of time to believers in the Son of God. 'We beheld his glory.'”58

Finally, many commentators believe the report of this theophany given to Moses in Exod 34:6 supplies the phrase "[full of] grace and truth" at John 1:14, 17. ${ }^{59}$ After putting Moses in the cleft of the rock, "the Lord passed before him and proclaimed, 'the Lord, the Lord, a God merciful and gracious, slow

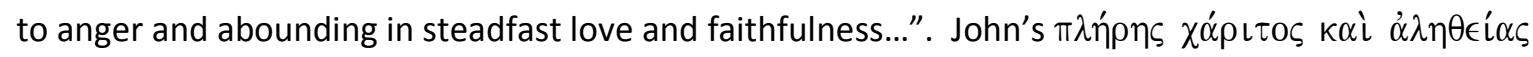
differs markedly from the LXX (

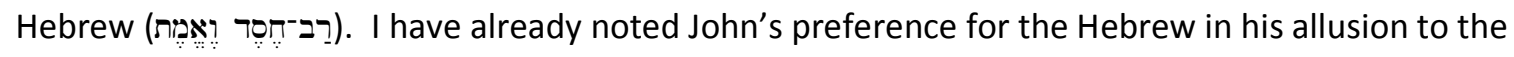
"dwelling" of God in Exod 25:8 and 29:46, and, in general, it is not out of character for John to work directly from the Hebrew text when citing the Old Testament. ${ }^{60}$ Moreover, the rendering of חסֶ by

\footnotetext{
${ }^{55}$ Cf. R. W. L. Moberly, At the Mountain of God: Story and Theology in Exodus 32-34 (Journal for the Study of the Old Testament Supplement; Sheffield: JSOT Press, 1983), 67-68, 98-100; similarly, Douglas K. Stuart, Exodus (The New American Commentary; Nashville: B \& H Publishing, 2006), 604.

${ }^{56}$ So Koester, Dwelling, 115; Kerr, Temple, 121-123; Keener, John, 408-410; Carson, John, 127; Evans, Word, 8182; Everett Harrison, "A Study of John 1:14," in Unity and Diversity in New Testament Theology: Essays in Honor of George E. Ladd (ed. Robert Guelich; Grand Rapids: Eerdmans, 1978) 23-35, $26-27$.

${ }^{57}$ Mowvley, "John 1:14-18", 136. Evans, Word, 80, suggests the further contrast between "the unique son who is in

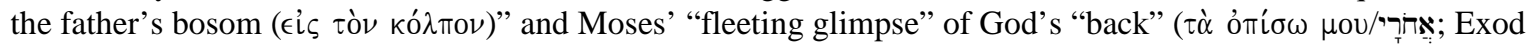
33:23).

${ }^{58}$ Harrison, "John 1:14", 29. Similarly, Rodney A. Whitacre, John, The IVP New Testament Commentary Series (Leicester: IVP, 1999), 59; Marsh, John, 109.

${ }^{59}$ See esp. the discussions in Keener, John, 405, 410-412, 416-22; Lincoln, John, 106-109; Evans, Word, 79-83; Kerr, Temple, 119-121. Cf. Koester, Dwelling, 104; Glasson, Moses, 97; Whitacre, John, 59; Hanson, "Exodus 34"; Lester J. Kuyper, “'Truth', a Key Word in St. John's Gospel," in Studia Evangelica Volume 2: Papers Presented to the Second International Congress on New Testament Studies Held at Christ Church, Oxford, 1961 (ed. F.L. Cross; Berlin: Akademie Verlag, 1964) 3; Wayne A.Meeks, The Prophet-king: Moses Traditions and the Johannine Christology (Supplements to Novum Testamentum, 14. Leiden: Brill, 1967), 288 n. 2.

${ }^{60}$ C.f., e.g., John's preference for the Hebrew of Zec 12:10 over against the LXX in John 19:37. See further on this the comments of Bruce G. Schuchard, Scripture Within Scripture: The Interrelationship of Form and Function in the Explicit Old Testament Citations in the Gospel of John (Dissertation Series; Atlanta, Ga: Scholars Press, 1992), 153-154, on John's familiarity with the Hebrew Scripture and the analyses of John's citations in Edwin D. Freed,
} 
$\chi \alpha \dot{\alpha}\llcorner\varsigma$, , though unusual in the LXX, is perfectly viable and perhaps even to be expected (over against ${ }^{\prime \prime}(\lambda \in O \varsigma)$ in the early Christian milieu. ${ }^{61}$

Clearly, then, John wishes to present the incarnation in relation to the revelation of God's glory at Sinai before Moses. But for what purpose? John 1:16-17 supplies the logical linkage between these parallel theophanies, a logic that establishes both continuity and discontinuity between the glory once revealed to Moses and the glory now revealed in Jesus.

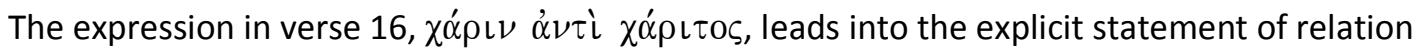
between the two revelations (ó $\tau$, v.17) and its import turns on the precise force of the preposition $\dot{\alpha} \nu \tau i{ }^{62}$ Harris describes three broad senses of this preposition in Hellenistic Greek: "equivalence (one object is set over against another as its equivalent), exchange (one object, opposing or distinct from another, is given or taken in return for another), and substitution (one object, that is distinguishable from another, is given or taken instead of the other)." He concludes that the "prevailing sense" of the preposition in both the LXX and non-Biblical Greek literature is that of "substitutionary exchange". ${ }^{63}$

Few would dispute that the idea of "substitutionary exchange" stands behind the use of $\alpha \nu \tau i$ in John 1:16. Nevertheless, the phrase remains open to two distinct interpretations. The chief alternatives are reading the preposition with an additive or cumulative force ("grace upon grace" or "one grace after another") versus reading it with a substitutionary force ("grace instead of grace"). Harris assumes the former without discussion of the alternative, and many commentators take the same reading. ${ }^{64}$ Strictly

Old Testament Quotations in the Gospel of John (Supplements to Novum Testamentum, 11. Leiden: Brill, 1965); and M. J. J. Menken, Old Testament Quotations in the Fourth Gospel: Studies in Textual Form (Kampen: Kok Pharos, 1996).

${ }^{61}$ Barrett, John, 167; Keener, John, 416-417. Noteworthy in this regard is the observation of James A.

Montgomery, "Hebrew Hesed and Greek Charis," HTR 32 (1939) 100 (cited in Hanson, Interpretation, 100) that the

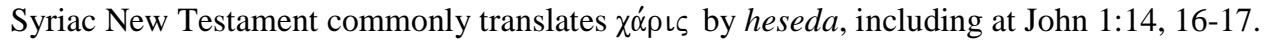

${ }_{62}^{62}$ The question has been much discussed by John scholars. See the overview in Carson, John, 131-134.

${ }^{63}$ Murray Harris, "Appendix: Prepositions and Theology in the Greek New Testament," NIDNTT 3.1171-1215 (1179), citing as representative the examples of the substitution of the ram for Isaac in Gen 22:13 and of Judah for Benjamin in Gen 44:33. James Hope Moulton and George Milligan, The Vocabulary of the Greek Testament: Illustrated from the Papyri and Other Non-literary Sources (London: Hodder and Stoughton, 1930), 46, describe the same range of meaning in the papyri and conclude in similar fashion: "By far the commonest meaning of $\alpha \nu \tau i$ is the simple 'instead of." Most recently, C. Blumenthal has surveyed comparable constructions in a range of Hellenistic Greek sources and settled on the concept of "einen kompensatorischen Austausch" as the clear meaning of John's

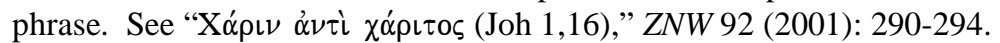

${ }^{64}$ Harris, "Prepositions", 1179, states the phrase "denotes a perpetual and rapid succession of blessings, as though there were no interval between the arrival of one blessing and the receipt of the next." See also Lindars, John, 97; Rudolph Bultmann, The Gospel of John: A Commentary (Translated by G. R. Beasley-Murray. Oxford: Blackwell, 1971), 78; Marsh, John, 111; Barrett, John, 168; F. F. Bruce, The Gospel of John (Grand Rapids, Mich: Eerdmans, 1983), 43; Schnackenburg, John, 1.275-276; Hodges, "Grace”, 40; Beasley-Murray, John, 15; Ridderbos, John, 56; Whitacre, John, 60. Support for this reading is commonly sought by appeal to a similar expression in Philo Posterity of Cain 145 (e.g., Lagrange, Jean, 25). For refutation, see Carson, John, 131-132, and R. B. Edwards,

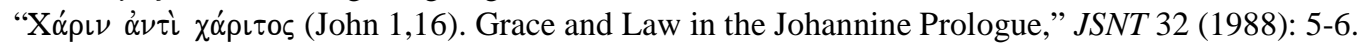


speaking, the preposition does not allow the notion of "abundance of grace" (i.e., "grace upon grace") ${ }^{65}$, though the idea of a succession of distinguishable blessings (e.g., NIV "one blessing after another") cannot be ruled out on lexical grounds. Context suggests, however, that the more straight-forward substitutionary sense "instead of" fits the phrase best. ${ }^{66}$ John invokes the Sinai theophany beginning in v.14 and it retains his attention through v.18. This revelation centers on the declaration in Ex 34:6 that the grace (חס) of God forms the hope and foundation of the life of his people, Israel. As this revelation of God's glorious grace is juxtaposed with the revelation in Jesus at vv. 14, 17, 18, it is probably best to understand the twin uses of $\chi \alpha \dot{\alpha} \rho \varsigma$ at v.16 as referring, respectively, to the incarnation and Sinai. This reading also creates a more natural flow of thought into $v .17$ which begins with the connective ö $\tau \iota^{67}$

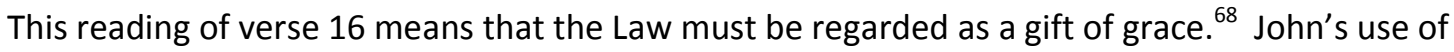
the terms "Law" and "grace" differs from the use commonly ascribed to Paul by traditional (i.e., "Lutheran") interpreters. ${ }^{69}$ Whereas Paul is often thought to use the terms in an ethical sense in which grace and law represent contrasting approaches to salvation, John uses the terms in a revelatory sense in which Law is one form of gracious revelation of God. ${ }^{70}$ This observation leads to the conclusion that the contrast set forth in John 1:17 is not between two paths to salvation (one by grace, the other not), but between two forms or revelations of grace (one through Moses, one through Jesus). Since verse 16 characterizes the Law as a gift of grace, I suggest that the contrast in verse 17 turns not upon the term "grace", but the term "truth". ${ }^{71}$ Harrison points out that the use of "true" in 1:9 shapes the import of the word in 1:14 and 16 . He is worth quoting at length:

\footnotetext{
${ }^{65}$ So, rightly, Lincoln, John, 107, and Carson, John, 131, who note in this case the preposition typically used is $\epsilon \pi i$.

${ }^{66}$ So, Carson, John, 132; Mowvley, "John 1:14-18", 137; Edwards, "John 1:16", 6-7 (citing also Chrysostom, Cyril of Alexandria, Origen and Theophylact).

${ }^{67}$ Lincoln, John, 107.

${ }^{68}$ Edwards, "John 1:16", 7 cites several early fathers, including Chrysostom, Cyril of Alexandria and Jerome, who take this view of the Law in 1:17 and read $\chi \dot{\alpha} \rho\llcorner\nu \dot{\alpha} \nu \tau \dot{\imath} \chi \alpha \dot{\alpha} \rho \iota \tau o \zeta$ as the replacement of the Law by the Gospel. For a modern example, see Lagrange, 25; Thomas L. Brodie, The Gospel According to John: A Literary and Theological Commentary (New York: Oxford University Press, 1993), 144.

${ }^{69}$ Edwards, "John 1:16", 7, lists several scholars who expressly read John along Pauline lines, insisting that Law cannot be called grace, here (e.g., Marsh, John, 111). Both Edwards, "John 1:16", 7-8, and Harris, Prologue, 65, argue forcefully against reading Pauline categories into John 1:17.

${ }^{70}$ Recall, again, John's repeated emphasis of the revelatory function of the Law as in 1:45 and 5:46. See esp. Pancaro, Law, 527-528 (and more generally, 514-516); Harris, Prologue, 65.

${ }^{71}$ Together with other commentators, I regard the construction "grace and truth" as grammatically analogous to "spirit and truth" in 4:23-24: a hendiadys in which the latter term qualifies the former. See Bultmann, John, 73-74; BDF §442; Moloney, Belief, 44; Ridderbos, John, 163-164 (noting the parallel with 4:23-24); Harris, Prologue, 69. Pointing to usage of "truth" in the rest of the Gospel, Keener, John, 417-419, Pancaro, Law, 537-541, and Kuyper, "Grace", 14, likewise view the emphasis of the construction as falling upon the "truth" side of the phrase. Edwards,

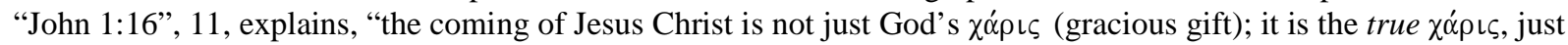
as Christ is the true vine, the true or real bread from heaven" (italics his). So also Schnackenburg, John, 1.273.
} 
The emphasis in this word is not on true as opposed to false (John the Baptist is not being denigrated), but true in the sense of complete or ultimate as opposed to the partial and the preparatory. As a light, the Baptist bore faithful witness, but over against him and his work stands the true light who is able to illumine the whole spiritual realm. ...By saying that the incarnate one is full of truth, John is saying more than that he is the revealer of the knowledge of God and his ways. If this one is the $\lambda$ ó $\gamma \circ \varsigma$, the effulgence of the Father's glory, then he is the truth in its essence and permanence. He has come not only to make the Father known with a fullness impossible before, but to become the one indispensible way to the Father (14:6). ${ }^{72}$

The contrast between the Baptist and Jesus is parallel to the contrast between the revelation of divine glory through Moses and that which came through Jesus. The issue is not one of right and wrong, true and false, ${ }^{73}$ but partial versus full and provisional versus final. The contrast of John 1:17, therefore, is both redemptive-historical and ontological. ${ }^{74}$ The law represented a gracious revelation of the love of God for his people. It remained, however, temporary and incomplete. The incarnation and death of the Word represents a complete and permanent revelation of divine grace. ${ }^{75}$

It must be emphasized, however, that while this reading of John 1:16-17 accords a more exalted status to the Law of Moses than is sometimes allowed, the difference between the revelations is not merely one of scale. ${ }^{76}$ Jesus is not simply an extension or elaboration of what came before. As observed

\footnotetext{
${ }^{72}$ Harrison, "John 1:14", 34 (emphasis original).

${ }^{73}$ Morris, John, 99.

${ }^{74}$ In the final section of this chapter I will argue that the contrast must not be restricted to a merely temporal one, but must recognize also the fundamental difference in order of being.

${ }^{75}$ In the incarnation, God "peut se manifester plus complètement" (Lagrange, Jean, 23). Schnackenburg, John, 2.228, says as much when he comments on the import of "truth" in John 1:17, "In being set in opposition to the 'Law' given through Moses, [the incarnation] is given the status of the definitive revelation of salvation." Similarly, Aalen, "Truth", 7: John 1:17 "seems to imply a contrast between a higher and lower stage in the history of revelation."

${ }^{76}$ Here I must depart from the otherwise senitive treatment by Keener of the continuity and discontinuity between the revelations in John 1:14-17. Perhaps overcorrecting for interpretations which eliminate all continuity, at several points he understates the true radicalness of discontinuity. For example, he speaks of Christ "completing what was partial (but actually present) in Torah" (John, 417); regarding verse 16, he suggests that "accumulation may make more sense than substitution: grace added to grace" (John, 421); and he defines the contrast in verse 17 as "one of intensity more than quality" (John, 421). (Others who are uncomfortable with a contrast of kind or quality, preferring instead a temporal or redemptive-historical contrast include Eldon Jay Epp, "Wisdom, Torah and Word: The Johannine Prologue and the Purpose of the Fourth Gospel," in Current Issues in Biblical and Patristic Interpratation (ed. Gerald F. Hawthorne; Grand Rapids: Eerdmans, 1975), 140-141; Ridderbos, John, 57-58.) These formulations of the relationship undervalue the very great difference of essence between the revelations. As the distinction between the Baptist and Jesus in 1:6-9 is analogous to a sign and the signified (this is part of the meaning of John's water-baptism; see my discussion below), so the relationship between the Law and Jesus is not only temporal but qualitative (Kerr, Temple, 131, also uses the analogy of a sign and the thing signified). Indeed, the salvation Jesus brings in John is radically other from current practice of the Law. I will argue below that this is the force of John 3:31-34 and 4:21-24.
} 
in the parallel with the Baptist in 1:9, the language of "truth" denotes a fundamental difference of essence. The important continuity between the revelations of divine grace through Moses and Jesus must not obscure the equally important discontinuity that distinguishes them.

The incarnation is comparable to the theophany at Sinai in that it is a revelation of the glorious character of God. In this way Keener, Edwards and others are quite correct to emphasize the continuity between the revelations and to regard the contrast as one of intensity rather than of the thing revealed. ${ }^{77}$ Yet, whereas the glorious love of God was declared to Moses, it was brought about through the incarnation, life and (especially) death of Jesus. Here is where the full weight of discontinuity comes to be felt. What came before was a gracious revelation, but a revelation that functioned as a kind of prophecy. The grace revealed through Jesus, though also a revelation, brought to pass that to which the former revelation pointed. John seems to draw attention to this very point in his use of verbs in the parallel clauses in verse 17: whereas the Law was given ('€́ó $\theta \eta)$ through Moses, "grace and truth

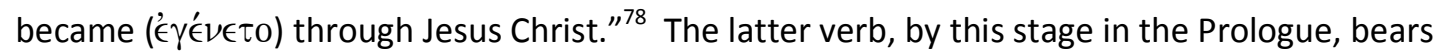
connotations of creation ${ }^{79}$ and so stands in stark contrast to the notion of verbal declaration associated with the giving of the Law (cf. John 9:29, "we know that God has spoken to Moses").

The distinction between the display of divine grace at Sinai and its enactment in Jesus may be clarified further by noting the subsequent usage of "flesh" in the Fourth Gospel. Reference to the flesh of Jesus is made seven times in the Gospel: once at 1:14 and six times in 6:51-56. The sevenfold use of the term in these two passages and nowhere else suggests the two contexts are mutually informing. ${ }^{80}$ One implication of this is the recognition that for John the reason the Word took on human flesh was so

\footnotetext{
77 "The glory revealed to Moses...was the very same glory John and his friends saw in the Word-made-flesh" (Carson, John, 129). Similarly, Whitacre, John, 61.

${ }^{78}$ See Whitacre, John, 60-61, and esp. Richard Bauckham, God Crucified: Monotheism and Christology in the New Testament, The Didsbury Lecture Series, 1996 (Carlisle: Paternoster, 1998), 68-69. He observes, "through Jesus Christ grace and truth happened - the divine self-giving occurred in full reality - and in this way the glory of the God whom no one has ever seen was revealed (John 1:14-18)." (italics his)

${ }^{79} \mathrm{Cf}$. the implied contrast between John the Baptist who "became" (1:6) with the Word who always "was" (1:1). Indeed, new creation seems to be precisely the idea evoked by the latter clause of verse 17: twice previously the preposition $\delta\llcorner\dot{\alpha}$ associates the creation of the old order with Jesus $(1: 3,10)$, perhaps preparing for this third and final occurrence of the preposition with Jesus to point to new creation. Support for this reading of 1:17b comes from two

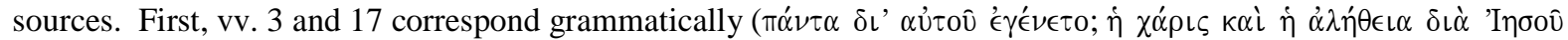

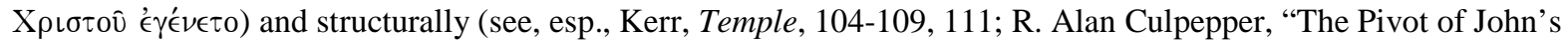
Prologue," NTS 27 (1980-1981) 10). This bolsters the suggestion of thematic correspondence. Second, the salvation brought by the Word is described as new birth (1:12-13). Such imagery fits naturally with the idea of new creation. Both of these points suggest that which "comes about through Jesus Christ" in v.17b is new creation.

${ }^{80}$ Moloney, Belief, 41-42; idem., Signs, 53; John Dennis, Jesus' Death and the Gathering of True Israel: The Johannine Appropriation of Restoration Theology in the Light of John 11:47-52 (WUNT, Tübingen: Mohr, 2006), 198-199.
} 
that he might give it over to death on the cross. The fullness of the glorious grace of God is displayed not simply in the incarnation of the Word, but in his death on the cross for the life of the world.

Thus, whereas the Mosaic revelation was declarative and prophetic, ${ }^{81}$ grace and truth "were created" or "happened" through Jesus Christ. The point at which the difference between Sinai and Jesus is most pronounced is not the mode of revelation (a spoken word ${ }^{82}$ versus a human life lived, tablets of stone versus human flesh). The most important difference is in the very nature or kind of revelation: prophecy versus fulfillment, hope versus realization. ${ }^{83}$ The eschatological revelation of God's glory does not simply unveil the glorious grace of God in all its fullness (though this is certainly true), it accomplishes salvation for the world, life from the dead and liberation from sin and Satan. In this sense, it is not merely instructive or illuminating as to the divine nature, it is salvific for the human condition. Whereas Sinai represents for John the partial revelation of divine glory, the incarnation-unto-sacrificialdeath of Jesus represents at one and the same time the fullest revelation of God's glory and the realization of salvation for the world.

Here, it may be appropriate to anticipate a conclusion I will draw later in the chapter. This careful distinction between the continuity and discontinuity of the two revelations in 1:17 calls for an important balance to be struck in the representation of Jesus' view of Judaism. Clearly, as a revelation of divine grace, Judaism receives strong affirmation as good and legitimate. On the other hand, the revelation of the fullness of divine grace in Jesus necessarily leads to a change in the status of the prior, provisional revelation of grace through Moses. Though adequate to the purpose for which it was first "given", the Mosaic revelation is no longer adequate in view of the coming of that for which it was intended to prepare. Manifestly, John does not regard the continuation of the practice of Judaism as it was before the coming of Jesus as a valid response to this climactic revelation of divine grace. On the contrary, John writes for the very purpose of seeking a response that leads beyond the prior, provisional revelation to the final, full revelation. The incarnation, death and resurrection of Jesus are the culmination of the history of God's redeeming program in the world and as such represents the "telos" or goal to which the law (for John) pointed and prepared. It is in terms of this redemptive-historical turning point that John must be understood as representing Judaism simultaneously as good and legitimate (even exalted), and as no longer adequate for the worship God seeks.

By way of summary, when John employs the formula "grace instead of grace" he signals in the most deft way both the continuity and discontinuity which characterize the relationship between the

\footnotetext{
81 “essentially promissory revelation" (Carson, John, 133-134).

${ }^{82}$ Cf. John 9:29, "we know God has spoken to Moses".

${ }^{83}$ I will elaborate upon the underlying concept, here, in my analysis of 3:31-34, below.
} 
two revelations. This understanding of the Prologue prepares the reader to understand Jesus' relationship to the Law displayed in the body of the Gospel in his interaction with the various institutions of Judaism. As Jesus never adopts a negative attitude toward the Law but rather sees himself as the fulfillment of it, so he does not condemn the institutions of Judaism but participates in them. ${ }^{84}$

\section{Contribution of John 2-4 to question of Judaism}

\section{C.i. Introduction: the literary unity of chs 2-4}

Subsequent chapters in this thesis will examine Jesus' appropriation of the symbolism and traditions surrounding the three Jewish feasts in the Fourth Gospel. At this point, however, I would like to turn to a consideration of John 2-4, chapters which have not always received due consideration in discussions of the Judaism in John but which, I believe, provide remarkable additional insight into the concepts set out above in my review of the Prologue. I make no pretention, of course, to providing a thoroughgoing examination of these chapters; indeed, I will be very selective in my treatment. In a word, I believe that the theme of the arrival of the messianic bridegroom, as developed in 2:1-11, 3:2236 and 4:1-46, extends the basic ideas I argued for in 1:16-17 in several illuminating ways that remain largely under-appreciated by scholars. ${ }^{85}$

The several narratives comprising John 2-4 form a literary unit. This is evident, first, by the editorial comment at John 4:46 ("then he came again to Cana of Galilee where he made the water wine") which forms an inclusio with the opening narrative in 2:1-11. ${ }^{86}$ In addition, there are a number of catchwords and themes that recur at select points in John 2:1-4:46 strengthening the sense of unity across the section. Several of these terms, denoted by an asterisk $\left({ }^{*}\right)$, occur only here in the Gospel.

Verbal correspondences

\begin{tabular}{|c|c|}
\hline 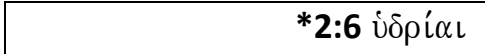 & 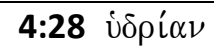 \\
\hline
\end{tabular}

\footnotetext{
${ }^{84}$ Edwards, “John 1:16", 8-9, and Whitacre, John, 61, reason similarly. For Jesus' participation in Judaism, note his regular presence in Jerusalem during feast-time (often within the Temple precincts; cf. 2:13-22; 5:1-47; 7:10-10:39; 11:55-19:42).

${ }^{85}$ The lack of attention commonly devoted to the bearing of John 2-4 upon the question of Judaism goes hand-inhand with the comparative neglect of these chapters as a whole. See the opening comments in Lars Kierspel, “'Dematerializing' Religion: Reading John 2-4 as a Chiasm," Bib 89 (2008): 526-554.

${ }^{86}$ A number of scholars note the double role played by 4:46-54, forming an inclusio with 2:1-11 around chs 2-4 while also looking ahead to the theme of life in chs 5-10. See Kierspel, "Dematerializing", 532-538; A. Feuillet, Johannine Studies (Translated by Thomas E. Crane.Staten Island, N.Y.: Alba House, 1965), 39-51; Brown, John, 198; Moloney, Belief, 177; Keener, John, 630.
} 


\begin{tabular}{|c|c|}
\hline 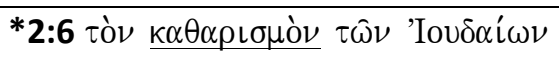 & 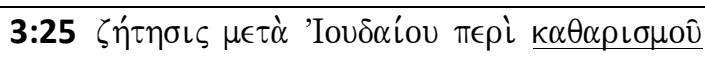 \\
\hline *2:6 $\mu \epsilon \tau \rho \tau \grave{\alpha} \varsigma$ & 3:34 $\mu \dot{\prime}^{\prime} \tau \rho o v$ \\
\hline $\begin{array}{c}\text { *2:8 } \dot{\alpha} \nu \tau \lambda \eta \dot{\eta} \sigma \alpha \tau \epsilon \\
\text { 2:9 oi } \eta \dot{\eta} \nu \tau \lambda \eta \kappa o ́ \tau \epsilon \varsigma\end{array}$ & $\begin{array}{l}4: 7 \stackrel{\alpha}{\alpha} \tau \tau \lambda \hat{\eta} \sigma \alpha \iota \\
4: 11 \stackrel{\alpha}{\alpha} \nu \tau \lambda \eta \mu \alpha \\
4: 15 \dot{\alpha} \nu \tau \lambda \epsilon \hat{\imath} \nu\end{array}$ \\
\hline 2:9 oủk प̆ & 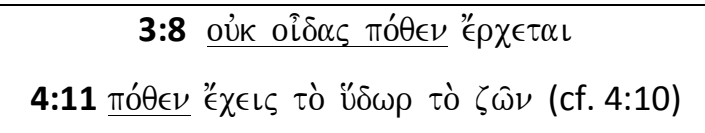 \\
\hline 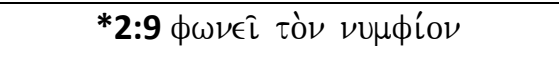 & 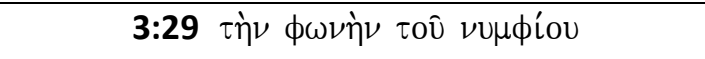 \\
\hline 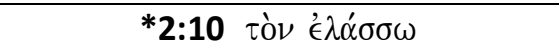 & 3:30 $ं \lambda \alpha \tau \tau 0 v ิ \sigma \theta \alpha \iota$ \\
\hline
\end{tabular}

Thematic correspondences

\begin{tabular}{|c|c|}
\hline 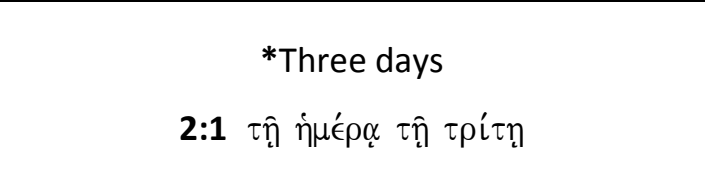 & 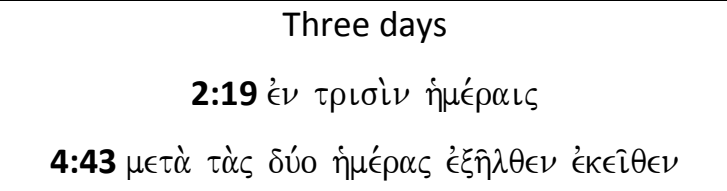 \\
\hline *2:1 Wedding & $\begin{array}{l}\text { 3:29 'the one who has the bride...' } \\
\text { 4:4-26 marriage type-scene }\end{array}$ \\
\hline 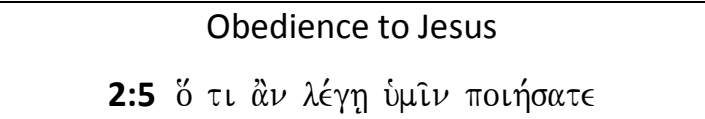 & 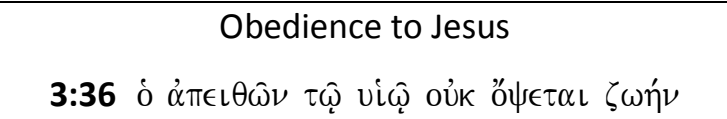 \\
\hline $\begin{array}{l}\text { 2:6 Water from source associated with } \\
\text { Judaism (stone jars) }\end{array}$ & $\begin{array}{l}\text { 4:4-14 Water from source associated with } \\
\text { Judaism (Jacob's well) }\end{array}$ \\
\hline $\begin{array}{l}\text { 2:6-7 Super-abundance of water supplied by } \\
\text { Jesus }\end{array}$ & $\begin{array}{c}\text { 3:34 Super-abundance of Spirit supplied by } \\
\text { Jesus }\end{array}$ \\
\hline 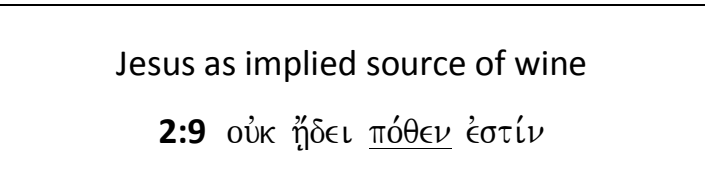 & 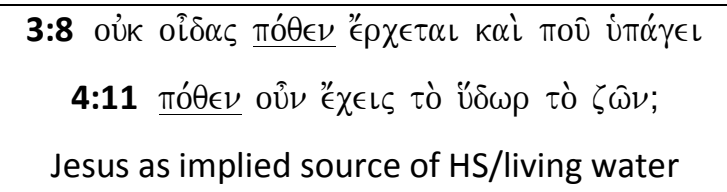 \\
\hline 2:1-11 Joy of a wedding? (cf. tone of 2:10) & 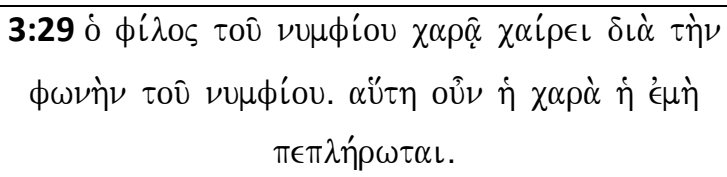 \\
\hline
\end{tabular}

These catchwords contribute to the unity of John 2-4. Careful scrutiny, however, reveals additional noteworthy features. To begin with, one of the two points of verbal or thematic correspondence, in every instance, occurs in the opening narrative of 2:1-11. It is striking that so brief 
and carefully constructed a story as the wedding at Cana should contain so many words and themes which occur again only in chapters 3-4. A second observation to be noted is that in all but two instances $(2: 19 ; 3: 8)$, the second correspondence in each of these pairs occurs in one of the twin narratives in 3:22-4:46.

I do not suggest that every correspondence indicates a thematic link between the respective verses. For example, there seems to be no exegetical connection between the jars of the wedding at Cana (2:6) and the jar used by the Samaritan woman (4:28). Rather, these correspondences collectively serve a literary purpose. The subtle author of the Fourth Gospel has created an array of verbal and thematic linkages between these three narratives (using expressions often found nowhere else in the Gospel) for the purpose of drawing attention to a common motif: the arrival of the messianic bridegroom. ${ }^{87}$ In this way, the author prompts the reader to interpret the passages together in a way which illumines this motif from multiple angles. ${ }^{88}$

On a first pass over the passages in question (John 2:1-11; 3:22-36 and 4:1-46) one is struck that all three correlate marriage imagery, water imagery, the nearing of Jesus' "hour" and the role of Judaism in his ministry. In what follows, I will briefly survey each passage in order to note the presence of these themes and to highlight the interplay between the messianic bridegroom motif and the role of Judaism. Having done this, I will be in a position to show that John 2-4 elaborates the relationship between Jesus and Judaism set forth in 1:16-17 in three important ways: it qualifies the role played by Judaism both in terms of what it can and cannot accomplish, and it elaborates upon why Jesus is set forth as superior to Judaism.

\section{C.ii.1. John 2:1-11}

The central claim of the rich story depicted in John 2:1-11 is that the hour of the messianic wedding is approaching and Jesus will himself provide that which is necessary for the celebration of the wedding. The wedding imagery is redolent of Messianic salvation. Beginning in Isa 25:6-9 and with further development in Isa 54:4-55:2 the arrival of God's deliverance for his people was likened to a wedding banquet. The specifically messianic character of the salvation depicted by John is indicated by

\footnotetext{
${ }^{87}$ Another example of this phenomenon is the use of the rare $\dot{\alpha} \nu \theta \rho \alpha \kappa\llcorner\dot{\alpha}$, "charcoal fire", at John 18:18 and 21:9 (and in only two other places in the entire Greek Bible) for the purpose of linking the two scenes together: Peter's threefold denial of Jesus and his threefold confession of love for Jesus. Cf. Lincoln, John, 512.

${ }^{88}$ A recent and illuminating study of the wedding metaphor in John by Jocelyn McWhirter (The Bridegroom Messiah and the People of God: Marriage in the Fourth Gospel (Society for New Testament Studies Monograph Series; Cambridge: Cambridge University Press, 2006), esp. ch. 2) discerns the same thematic pattern linking these three passages together though without developing its significance in the same way I do.
} 
the abundance of wine traditionally associated with the messianic age. This theme is traceable from the oracle of Jacob regarding the future rule of Judah (Gen 49:10-12) and the climactic prophecy of Amos in which the restoration of Davidic rule is accompanied by hills and mountains flowing with "sweet wine" (9:11-14), to the late-first century C.E. Jewish association of the messiah's advent with superabundant wine (2 Bar 29:3-6). ${ }^{89}$ The association of the messianic age with a wedding celebration is widely attested in the New Testament. In Matt 22:2 Jesus likens the coming of the Kingdom of God "to a king who gave a wedding feast for his son". Revelation 19:6-9 refers to the consummation of Christ's kingdom as "the marriage of the Lamb". Paul also uses the metaphor of a bridegroom and his bride to portray the relationship of Christ to the church (cf. 2 Cor 11:2; Eph 5:23ff., though the authorship of the latter is, of course, disputed). The prominence of this motif in the Jewish background as well as the New Testament strengthens the likelihood that the scene at Cana casts Jesus as the messianic bridegroom of national expectation..$^{90}$

Another important, though more subtle, facet of the account is the use of words marking time. ${ }^{91}$ At the start of the narrative Jesus' hour "had not yet come" (2:4). But his willingness to meet the need of the celebration brought about a work which constituted "the beginning of his signs" (2:11),

\footnotetext{
${ }^{89}$ See discussions in McWhirter, Bridegroom, 47-49; Brown, John, 105; Craig R. Koester, Symbolism in the Fourth Gospel: Meaning, Mystery, Community (2nd ed. Minneapolis: Fortress Press, 2003), 83-84; Larry Paul Jones, The Symbol of Water in the Gospel of John (Journal for the Study of the New Testament Supplement Series, 145. Sheffield: Sheffield, 1997), 56 ("the narrator thus places Jesus in a situation in which he can perform an act symbolic of the arrival of the messianic age"). Whitacre, John, 80, notes the confluence of both wedding and abundant wine imagery in a restorational context in Hos 2:14-23. Martin Hengel, "The Dionysiac Messiah," in Studies in Early Christology (ed. Martin Hengel; Edinburgh: T\&T Clark, 1995) 315, adduces further evidence from the coins minted during both wars with Rome, C.E. 66-73 and 132-135, in which coins bear the image of grapes, grape leaves and wine-cups. He claims these images "were motivated by eschatological-Messianic considerations", but Meshorer makes no mention of this. For photographs of the coins and descriptions of the imprints see Ya'akov Meshorer, Jewish Coins of the Second Temple Period (Tel Aviv: Am Hasefer, 1967), 154-169 and plates XIXXXVIII. Hengel also suggests that Jesus' practice of feasting with "tax-collectors and sinners" (Matt 11:19; note the messianic context) as well as his word to the disciples at the last supper about drinking wine again in the Kingdom of God (Mk 14:25) presuppose a correlation between the coming of the Messiah and feasting with abundant wine ("Dionysiac", 316-317; see also Feuillet, Studies, 74-75). Commentators sometimes adduce other texts which associate the eschaton with flowing wine (e.g. Jer 31:12; 1 En 10:19; cf. Brown, John, 105, and esp. Feuillet, Studies, 70-72), but these contribute nothing to the specifically messianic nature of this association (McWhirter, Bridegroom, 48 n.8).

90 "Thus, the headwaiter's statement at the end of the scene...can be understood as the proclamation of the coming of the messianic days" (Brown, John, 105). Some, such as McWhirter, Bridegroom, $49-50$ (following Jeffrey L. Staley, The Print 's First Kiss: A Rhetorical Investigation of the Implied Reader in the Fourth Gospel (SBL Dissertation Series; Atlanta, GA: Scholars Press, 1988), 90), hesitate to admit of more than a hint as to Jesus' status as bridegroom at this stage in the Gospel. This reluctance is unwarranted, however. Nathaniel's confession of Jesus' messiahship immediately before a wedding scene in which Jesus figures centrally, even receiving indirect praise as bridegroom (Paul D. Duke, Irony in the Fourth Gospel (Atlanta: John Knox Press, 1985), 84), cannot but indicate the author's clear (even if subtle) interest in portraying Jesus as messianic bridegroom. Koester, Symbolism, 83 , also notes the importance of the messianic identification of Jesus in the preceding context for the message of 2:1-11.

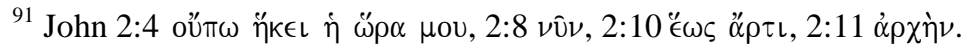


of which the last would be the cross. In between, two important time references strongly signal that a transition has taken place. ${ }^{92}$ The first of these is the final command of Jesus to the servants: "now (v0̂v) draw some and take it to the master of the banquet" $(2: 8)$. The second forms the very last word in the climactic pronouncement from the master: "Everyone serves the good wine first, and when people have drunk freely, then the poor wine. But you have kept the good wine until now (" $\left.\epsilon \varsigma \alpha^{\prime \prime} \rho \tau \iota\right)$ " $(2: 10)$. In the narrative world of the wedding celebration, these mark the transition from the original wine to the "good wine" which Jesus provided. Yet, against the wider setting of Jesus' ministry (express concern for which frames the narrative in $2: 4,11$ ) these temporal markers are suggestive of a transition within Jesus' ministry. In the course of wedding at Cana, the timing of Jesus' ministry becomes intertwined with the timing of the wedding such that Jesus' hour undergoes a progression from not yet begun (oütw $\omega$ ) to beginning $(\dot{\alpha} \rho \chi \grave{\eta} \nu) .{ }^{93}$ The messianic bridegroom has arrived and the hour of his wedding now draws near.

A final feature of the narrative which requires attention is the role of the stone jars in 2:6. The jars appear at the center and pivot point of the narrative and, though normally serving as implements for Jewish rituals of purification rather than wine storage, are used by Jesus to provide the needed wine. ${ }^{94}$ Moreover, Jesus could just as easily have told the servants to get water and bring it directly to the steward from the well. ${ }^{95}$ All of this suggests that the jars perform a role in the brief account out of all proportion to any reasonable expectation. The most likely explanation for the use of the jars is their symbolic value as representative of Jewish religion. ${ }^{96}$

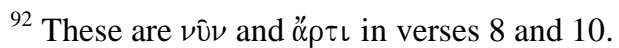

${ }^{93}$ For a similar reading, see Keener, John, 506-507; Brodie, John, 171. Birger Olsson, Structure and Meaning in the Fourth Gospel: A Text- Linguistic Analysis of John 2:1-11 and 4:1-42 (Coniectanea Biblica, 6, New Testament

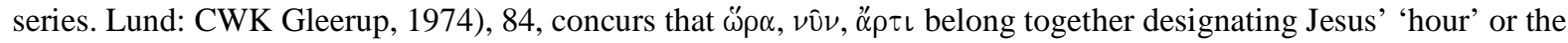
time following his hour, and Dennis, Gathering, 180-181, makes some helpful comments about the "eschatological 'now' ( $\nu$ v̂)" in John 4:23 that apply equally well to 2:1-11. In a similar vein, I. de la Potterie, "“Nous adorons, nous, ce que nous connaissons, car le salut vient des Juifs'. Histoire de l'exégèse et interpretation de Jn 4:22," Bib 64 (1983) 89, describes the " $\nu$ v̂ $v$ eschatologique" as "le temps messianique qui s'ouvre en ce moment peut donc se

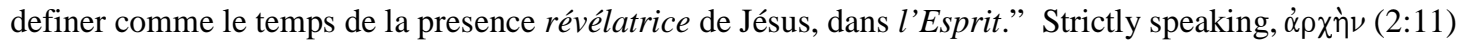
designates his signs, not his "hour". Thus, at 7:6, 8, 30 and 8:20 the arrival of his hour is expressly denied. Yet, the signs represent the beginning approach of his climactic hour since his death and resurrection constitute the final sign (cf. 2:18-22), and at other points of his ministry he can speak of the presence already of the eschatological salvation $(4: 23 ; 5: 25)$. It is best, then, to understand in the account of the wedding at Cana the beginning approach of his hour and and revelation of his identity as the messianic bridegroom.

${ }^{94}$ Jones, Symbol, 55, 58-60, notes the "informational interlude" of v.6 which devotes extended space to describing the jars and so invites the reader to ponder their significance for the story.

${ }^{95}$ See below for a critique of this reading.

${ }^{96}$ Representative of many commentators, Olsson, Structure, 50, says that purifications in the temple and elsewhere

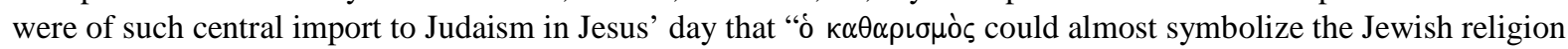
as a whole."
} 
Stepping back from this brief, thematic survey it can now be asked what John 2:1-11 conveys about the relationship between Judaism and the bridegroom messiah? Over against replacement readings which regard Judaism as symbolically set aside by Jesus, the stone jars, so far from being set aside, play an instrumental role in Jesus' miracle. Jesus has the servants fill the jars and draw from them to take the newly made wine to the steward. The important role played by the jars in the miracle has sometimes been obscured by faulty readings which regard the symbolism of the jars in a negative light. For example, some commentators have concluded from the use of the verb 'ं $\nu \tau \lambda^{\prime} \epsilon \omega$ that the servants brought the water to the steward directly from the well, bypassing the filled jars. ${ }^{97}$ But this is based on a mistaken assumption about first-century usage of the verb ${ }^{98}$ and gives insufficient regard to the requirements of the flow of thought within the narrative. ${ }^{99}$ Other scholars interpret the six jars as symbolic of incompleteness. ${ }^{100}$ I will suggest below that this is possible and may contribute to the purposes of the author for this narrative. Notwithstanding this, however, such numerological symbolism must not be viewed as implying judgment or condemnation upon Judaism as represented by the jars. ${ }^{101}$ The Gospel nowhere condemns Judaism nor even portrays it as deficient in the sense of lacking something it ought to have had. Rather, as we have seen, the Law is a gracious revelation of God (1:16) which perfectly accomplished that for which it was intended. ${ }^{102}$ Finally, the words of the master of the banquet (2:10) have sometimes been taken as a slight on Judaism (here symbolized by the wine). But his surprise arises precisely because the wine served up to that point met his expectations. The whole force of his statement is lost if the first wine is viewed as inadequate or of poor quality. Had the first wine been poor, it would make little sense for him to express his surprise so late in the feast. He could have been expected to have expressed his surprise at the outset when he first tasted it. The thrust of the steward's comment, then, lies not in its degradation of Judaism but in its exaltation of Jesus far above even the very good "wine" of Judaism. There is, therefore, no basis whatever for discerning negative connotations with regard to Judaism at any point in the narrative.

The significance of Jesus' usage of the stone jars for his provision of the wine, then, lies not in any implication of deficiency nor in the setting aside or bypassing of Judaism as represented by the jars. On the contrary, the import of the jars lies is the fact that Jesus turned to these representatives of

\footnotetext{
${ }^{97}$ E.g., Westcott, John, 1.84; Bruce, John, 71; Carson, John, 174 (following Westcott).

${ }^{98}$ Morris, John, 161 n.32; and Köstenberger, John, 97, who cites the use of the term in the $1^{\text {st }}$-century C.E. writer Dio Chrysostom (Orations 45.11) with reference to the draining of wine casks.

${ }^{99}$ Brown, John, 100; Olsson, Structure, 55; Keener, John, 511; Jones, Symbol, 60.

${ }^{100}$ E.g., Moloney, Belief, 85; followed by Köstenberger, John, 96; Coloe, Dwells, 69; Manns, L'Evangile, 103.

${ }^{101}$ Contra Coloe, Dwells, 69; Manns, L'Evangile, 103 (“Jean a l'intention de montrer l'imperfection de la loi Juive").

${ }^{102}$ I will return to this below when I treat John 4:22.
} 
Jewish religion to supply this need. In a scene proclaiming the arrival of the Messianic bridegroom the use of the elements of Judaism to provide for the need of the wedding celebration is most revealing. The symbolism of the scene suggests that Jesus will (somehow) work within and utilize the Jewish religion for the accomplishment of his work, as it were, "filling up" its institutions "to overflowing". ${ }^{103}$

Equally, however, the narrative highlights the special and unique contribution of Jesus himself in the supplying of the need. In and of themselves the jars could not meet the need of the wedding; the work of transformation by Jesus was requisite. It is possible that the number six contributes to this idea through numerological symbolism for incompleteness. ${ }^{104}$ Though this is not certain, it would highlight further the idea that for all its goodness Judaism was incapable of bringing the messianic salvation purposed by God. ${ }^{105}$

The point of the passage, then, is the arrival of the messianic bridegroom whose climactic salvation draws near. Jesus will bring about this blessing through the instrumentality of the Jewish religion. Yet, the fullness of messianic salvation is not a mere function of Judaism, but comes by a unique and special work of Jesus. As in 1:16-17, both continuity and discontinuity characterize the relationship between Jesus and Judaism.

\section{C.ii.2. John 3:22-36 ${ }^{106}$}

\footnotetext{
${ }^{103}$ Similarly, Dennis, Gathering, 166 n. 233.

${ }^{104}$ Morris, John, 161, may be justified to object that "the narrative contains nothing that would symbolize completeness" to correspond to the incompleteness of Judaism. Similarly, Barrett, John, 191; Carson, John, 174; Schnackenburg, 1.332; Jones, Symbol, 59. On the other hand, it may be overly pedantic to insist that numerological symbolism surrounding the jars must be paired with analogous symbolism surrounding Jesus. Perhaps "the narrator merely wishes to indicate that Judaism, along with its ritual, falls short of fullness" (Moloney, Belief, 85 n.34) in order to juxtapose this with the manifest fullness of the provision of Jesus signaled, not by a heptad of any sort but by the superabundance of wine (cf. 2:6-7).

${ }^{105}$ Again, the narrative itself precludes representing this inadequacy as a failure in any meaningful sense. I will argue below that 3:22-36 explains that the inadequacy was not a failure to achieve that for which it was intended, but was bound up with the (limited) divine purpose for Judaism and its institutions.

${ }^{106}$ In what follows I regard John the Baptist in the Fourth Gospel as coming under the umbrella of Judaism and therefore as useful for shedding further light on the relation of Jesus to Judaism. The primary ground for this view is that the baptizing ministry of John is associated with the Jewish concern for ritual purification (3:25; recall the

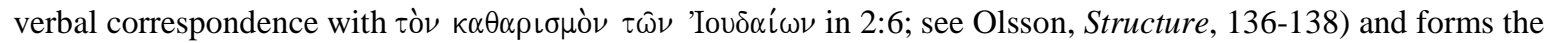
climactic prophetic work preparing for the Isaianic salvation of the Lord (John 1:23, on which see esp. Catrin H. Williams, "The Testimony of Isaiah and Johannine Christology," in "As Those Who Are Taught": The Interpretation of Isaiah from the LXX to the SBL (eds. Claire Matthews McGinnis and Patricia K. Tull; Society of Biblical Literature: Atlanta, 2006), 110-111, 123). In the second place, John 5:33-47 presents John's role as witness in parallel to that of Moses and the Scriptures generally. Similarly, 10:41 refers to his witness using phraseology very similar to that used of the witness of Moses, the Law and the prophets to Jesus: "everything John said

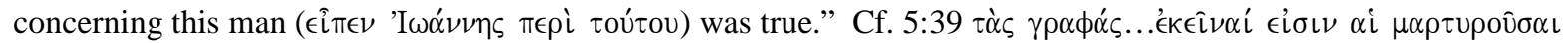

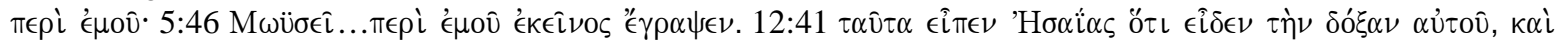

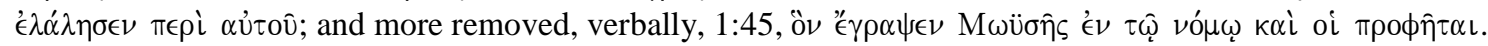
Finally, the locution of the Baptist interrupting the Prologue in verses 14-18 may further suggest John's position
} 
Turning to John 3:22-36, the onset and growth of Jesus' baptizing ministry becomes a cause for concern among John's disciples prompting John to explain the relationship between the two ministries in the metaphorical terms of a bridegroom arriving to take his bride (3:29). ${ }^{107}$ Though the language of Jesus' hour is absent, the theme appears unmistakably in John's words, "The friend of the bridegroom, who stands and hears him, rejoices greatly at the bridegroom's voice. This joy of mine is now complete." The beginning of the public baptizing ministry of Jesus signals a crucial transition in the realization of the Isaianic salvation John foretold (cf. 1:23). The coming of the messianic bridegroom spells the completion of John's own ministry.

The wedding metaphor helpfully portrays the three-way relationship between John, Jesus and the bride. John casts himself in a role not only lofty and dignified but critical to the success of the wedding. ${ }^{108}$ Not unlike a modern best man, the friend, or shoshbin, of the bridegroom made preparations for the wedding, ${ }^{109}$ served as witness to the event, ${ }^{110}$ contributed to the expense of the celebration, ${ }^{111}$ and even retained the evidence of the bride's virginity. ${ }^{112}$ Great joy characterized the role (cf. John's emphatic $\left.\chi \alpha \rho \hat{\alpha} \chi \chi i^{\prime} \rho \in \iota\right)$; indeed, it was incumbent upon the shoshbin to ensure the event was joy-filled. ${ }^{113}$ As the friend of the bridegroom, then, John is never intended to marry the bride himself, but rather to prepare the way before the groom. ${ }^{114}$ When the groom arrives John must yield to him, as the friend whose role is reaching its culmination and end.

under the umbrella of the Law, of Judaism. Though undoubtedly serving structural purposes vis-à-vis 1:6-8 (cf. Morna D. Hooker, "John the Baptist and the Johannine Prologue", NTS 16 (1969-1970) 357-358), it may also establish a certain continuity of function between the Law and the Baptist as provisional and preparatory for the revelation of Jesus. See Harris, Prologue, 26-39, 59-62.

${ }^{107}$ For a recent and helpful discussion of the marriage metaphor, here, see McWhirter, Bridegroom, 50-58, who argues cogently for an allusion in the words of the Baptist to the prophecy of Jer 33:10-11 in which "the sound of joy and the sound of gladness, the voice of the bridegroom and the voice of the bride" signal the eschatological restoration of the people by the Lord.

${ }^{108}$ See the helpful summary discussion in Keener, John, 579-580, and Ruben Zimmermann, "Der Freund des Bräutigams (Joh 3,29): Deflorations- oder Christuszeuge?” ZNW 90 (1999): 123-130.

${ }^{109}$ Paul casts himself in this role in 2 Cor 11:2: "I betrothed you to one husband, to present you as a pure virgin to Christ".

${ }^{110}$ Deut. Rab. 3.16 explains the reason why two tablets of stone were used for the writing of the Law by reference to the practice of having two shoshbins present for the wedding: to act as witnesses for the establishment of the new relationship between the two parties.

${ }^{111}$ See discussion in S. Safrai, "Home," in The Jewish People in the First Century: Historical Geography, Political History, Social, Cultural and Religious Life and Institutions (eds. S. Safrai and M. Stern; Amsterdam: Van Gorcum, 1976) 2.728-792 (757).

${ }^{112}$ Num. Rab. 18.12.

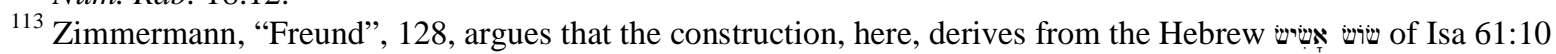
and notes that this text "im räbbinischen Judentum messianisch gedeutet wurde". Cf. Exod. Rab. 20.8. The shoshbin and groom were also commonly exempted from daily prayers and various other legal requirements $(t$.Ber. 2.10). See the considerable evidence compiled on this point by Keener, John, 580.

114 "Because of this special trust any impropriety between the best man and the bride was regarded as particularly heinous" (Brown, John, 152). Reasoning along similar lines, Carson, John, 212, points to the ancient Babylonian 
An important feature that comes to the fore, here, is the combination of, on the one hand, John's highly honored, joyful and unique role, and on the other hand, his subordination to Jesus. ${ }^{115}$ Zimmermann captures the twin realities well. Commenting on the contribution of 3:29 to the relationship between Jesus and John depicted in chapter 1 he says,

Das oben genannte Spannungsverhältnis wird auch hier deutlich und spitzt sich im Bildwort V.29 zu: Einerseits wird die Begrenzung des Täufers betont: Er ist nicht der Messias (V.28), nur irdisch (V.31), die Zahl der Anhänger nimmt ab (V.26), er selbst musst abnehmen (V.30). Zugleich erfullt der Taufer jedoch eine überaus positive Rolle. Er ist vertrauter Freund des Bräutigams, führt dem Bräutigam die Braut zu (Joh 1,35-39; 3,26: alle laufen zu ihm!), weist auf die himmlische Herkunft Jesu hin $($ Joh $3,27.31)$ und wird sein Zeuge (Joh 3,28). ${ }^{116}$

Like the stone jars at Cana, John is both instrumental to Jesus' work and yet insufficient of himself to accomplish the work only Jesus can perform. ${ }^{117}$ Thus, to the concern of his disciples that the baptizing ministry of Jesus has begun to eclipse that of John, he responds that this is precisely the way it must be because it is Jesus, not the Baptist, who is the Messiah of Israel (3:26-28). Indeed, so far from being an occasion of anxiety or resentment, John portrays this as an occasion of great joy as when the bridegroom arrives to take his bride and the wedding gets under way (3:29-30). His concluding words ("he must increase, but I must decrease") are as stark as they are poignant. There is to be no sharing of glory or royal prerogative. John must simply and utterly give way to the Messiah who has now come. ${ }^{118}$

and Sumerian law prohibiting the best man from ever marrying the bride (cf. also Judg 14:20-15:8) and suggests that John's reponse to his disciples amounts to an emphatic rejection of the very possibility of "competing with the bridegroom".

${ }^{115}$ Cf. Brodie, John, 206.

${ }^{116}$ Zimmermann, "Freund", 130.

${ }^{117}$ As the context makes clear (3:22-26), the contrast made here is not simply between John and Jesus, but the ministry of John and that of Jesus. Jones, Symbol, 83, also notes the conceptual parallel between the stone jars in 2:6 and the Baptist in 3:29-30.

${ }^{118}$ The motif of Jesus as the 'coming one' reaches a high point in this context and seems to play on the tandem 'comings' of the Baptist and Jesus in the Prologue (cf. 1:6-11, 15). At the culmination of the dialogue with Nicodemus comes the declaration, "this is the verdict, the light has come into the world" $(3: 19$; this is the first mention of Jesus "coming into the world" since 1:9). The following account about the concern of the disciples of John over the growing ministry of Jesus opens with the words "after these things Jesus came with his disciples into Judea... and he began baptizing" (3:22). This "coming" of Jesus seems to represent the beginning of his public ministry in earnest which explains the surprise of the Baptist's disciples and makes his response so appropriate ("my joy is [now] complete"). Similarly, W.R.G. Loader, "The Central Structure of Johannine Christology," NTS 30 (1984): 188-216 (189). Jones, Symbol, 83, renders the same essential appraisal of the import of John's words as my own. He concludes, "He has revealed Jesus to Israel and now faces the necessity of fading from view as Jesus moves toward his destiny." 
Why does John portray himself in this manner? Why represent himself as performing a role fundamentally subordinate, even if honorable, to that of Jesus? Verses 31-36, which supply the answer to this question, form one of the most important contributions to our understanding of the nature of the contrast between Jesus and Judaism in the Fourth Gospel. For this reason I must devote considerable space to examining the main lines of thought in the passage.

John 3:31-36 represents the continuation and explanation of the words of the Baptist in 3:2730. ${ }^{119}$ Beginning with 3:31, the author explains in the most elaborate terms thus far in the Gospel what sets Jesus apart from John (and by extension Judaism generally and, indeed, all humanity). The contrast turns on two issues: different origins, and different ministries. The difference in origins between the

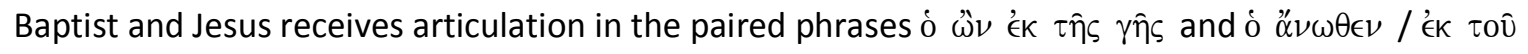

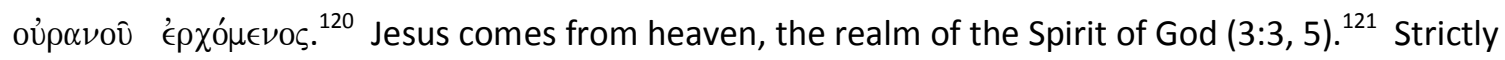
speaking, the association of Jesus with heaven does not suffice to set him apart from the Baptist since

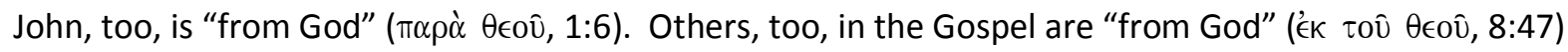
or "born from above" (" $\alpha \omega \theta \in \nu, 3: 3)$ in a sense which implies a change whether in status (possession) or capacity for spiritual discernment (cf. 6:44-46). However, only Jesus originates there and so can be said to have come from above (3:31) and "descended ( $\delta \alpha \tau \alpha \beta \alpha i \nu \omega \nu)$ from heaven" $(3: 13 ; 6: 33,38)$. Jesus is not imbued with heavenly qualities or authority subsequent to his arrival in the world; he is heaven come to earth. ${ }^{122}$

In his prior statements about Jesus John the Baptist highlighted this distinction in origin between the two men. Even as he acknowledges his temporal priority over Jesus in his earthly ministry, he

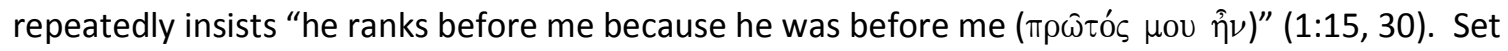
within the Prologue in which the pre-existence of the Word has already been juxtaposed to the created-

\footnotetext{
${ }^{119}$ Commentators divide over whether to attribute the words of 3:31-36 to the Baptist (noting the absence of a change in speaker at 3:31) or the Evangelist (noting the verbal and thematic overlap with 3:3-15). For discussion, see Brown, John, 159-160, and Beasley-Murray, John, 46. Harris, Prologue, 49, well observes, "Since the style of the evangelist colours all that is said by anyone in this gospel, there is little basis for determining whether John is the speaker on stylistic grounds. ...The theology of Jesus, John and the evangelist are couched in the same language and are legitimately understood as proceeding from the same pen." As to the function of 3:31-36, even if the passage be viewed as summing up themes from the chapter as a whole (Carson, John, 212; Brown, John, 160), its present setting immediately following the words of the Baptist, as well as the absence of any indication of a change in speaker, indicate the it furthers the thought of the Baptist in 3:27-30 (contra Beasley-Murray, John, 53). Keener, $J o h n, 581$, is therefore to be followed when he concludes, "if these are not [the words of the Baptist], the writer takes them as the logical implications to which the Baptist's testimony must point."

${ }^{120}$ On this, see esp. Westcott, John, 1.131-133.

${ }^{121}$ Throughout 3:31-36 echoes of 3:1-21 abound. Cf. Barrett, John, 224; Brown, John, 159-160.

${ }^{122}$ Commenting on the place of the "coming"-motif in this passage which is continued from the Nicodemus dialogue, Loader, "Christology", 189-190, says that Jesus "has indeed 'come from God', but in a sense far more profound than Nicodemus' words could comprehend (3:2)."
} 
ness of the Baptist by means of the verbs $\eta \hat{\nu}$ and ' $\gamma^{\prime}{ }^{\prime} \nu \in \tau o ~(1: 1,6$; e.g. Barrett, 152), the Baptist's formulation of the contrast in verses 15 and 30 clearly denotes pre-existence. The second halves of the

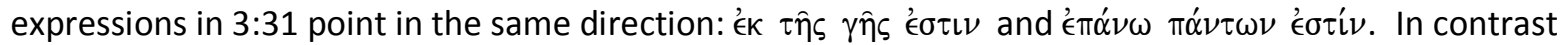
to John who is limited to the earth, Jesus originates in heaven and so exercises sovereign rule over the earth. ${ }^{123}$ Harris puts it this way: "with the appearance of Jesus upon the stage of history there is one who genuinely comes from above, that is, who is directly from God, and who as such is over all, occupying in relation to 'all' the position of God."124 In a word, that which separates Jesus from John is nothing short of the Creator-creature divide.

John 3:31-36 also delineates the contrast between Jesus and the Baptist along the lines of their respective ministries. ${ }^{125}$ Extrapolating from the difference in origins, the Evangelist proceeds to

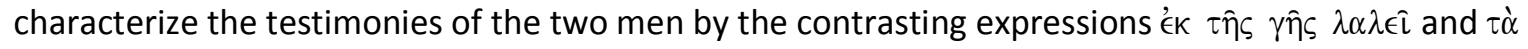
pं $\mu_{\mu \alpha \tau \alpha} \tau o \hat{v} \theta \in 0 \hat{v} \lambda \alpha \lambda \in \hat{i}$. This contrast does not cast the ministry of John in a negative light. The Gospel repeatedly characterizes the ministry of the Baptist as of divine origin, using the same language of "sending" as used of Jesus (Baptist: 1:6; 3:28; Jesus: 3:17, 34; 5:36, 38). Nor does the Evangelist hesitate to describe the witness of John as "true" $(5: 33 ; 10: 41)$. Thus, the description of the ministry of the Baptist as speech "from the earth" must not be construed as derogatory or belittling in any way. Rather, it points up the limitations inherent in a ministry which originates from the earth. ${ }^{126}$ In the same way as his mode of living and speech are from the earth, so also his teaching and ministry are subject to the limitations of finitude that characterize every facet of his existence. ${ }^{127}$ Though he baptizes in obedience to a divine commission (1:33), yet the mode of John's baptism is (merely) water and so cannot effect life from the dead and purification from sin. By virtue of its very mode of being his baptism is restricted to pointing to or signifying the coming Spirit-baptism which effects the true purification from sin and raises the dead to life: "for this reason I came baptizing with water, so that he might be revealed to Israel....The One who sent me to baptize with water told me, 'the one on whom you see the Spirit come down and remain, he is the one who baptizes with the Holy Spirit"' $(1: 31,33) .{ }^{128}$

\footnotetext{
${ }^{123} \pi \alpha \dot{\nu} \tau \omega \nu$ referring to all things as in 3:35, not simply "all people" as in 17:2; cf. Westcott, John, 1.131.

${ }^{124}$ Prologue, 58 (italics mine).

${ }^{125}$ This further distinction is not always noted by commentators who include Nicodemus within the purview of 3:31. But the issue raised by the disciples of the Baptist and developed in his response pertains to the respective ministries of the two men. Thus, while 3:31 undoubtedly contrasts the two men as men, it also contrasts their ministries.

${ }^{126}$ Westcott, John, 1.131-132, explains: "The 'earth' ...expresses the idea of particular limitations of our being, without any accessory moral contrast with God. Its opposite is heaven." So, too, Carson, John, 212; Margaret Davies, Rhetoric and Reference in the Fourth Gospel (Journal for the Study of the New Testament Supplement Series, 69. Sheffield: JSOT, 1992), 178.

${ }^{127}$ Again, Westcott, John, 1.132: there is a "correspondence between the offspring (issue) and the source."

${ }^{128}$ Jones, Symbol, 48, notes the implied contrast between the two baptisms in 1:33.
} 
Over against the one who speaks "from the earth", Jesus is said to speak "the words of God" (3:34). In the Fourth Gospel the "words of God" are uniquely the possession of Jesus because he alone comes from God. ${ }^{129}$ Jesus communicates precisely this idea when he claims to "speak what [he] has heard from God" (8:26, 38, 40; cf. 3:11) or when he declares (the climactic word of his public ministry), "I have not spoken on my own authority, but the Father who sent me has himself given me a commandment--what to say and what to speak.... What I say, therefore, I say as the Father has told me" (12:49-50; cf. 17:8). Drawing out the implication of this claim Harris observes,

\begin{abstract}
"In this he is in distinction from all others, who, having their origin from earth, can speak only as humanity speaks within the limitations of earth. As the one who is directly from God he is able, as is none other, to speak of that which he has seen and heard in the presence of God, and this constitutes the subject of his witness to God." ${ }^{130}$
\end{abstract}

Moreover, the "words of God" do not merely testify to the truth, they are truth. As the teaching of God Jesus' teaching imparts life to those who accept it (cf. 5:24). Thus, Jesus responds to the unbelief of some of his disciples following his discourse about the "true bread from heaven" by stating plainly, "the Spirit is the one who gives life, the flesh counts for nothing; the words which I have spoken to you are Spirit and they are life" (6:63). Peter's concluding observation a few verses later pulls these concepts together: to Jesus' query whether the twelve wish to depart along with those who could not accept his teaching Peter responds, "Lord, to whom shall we go? You have the words of eternal life" (6:68). Jesus uniquely possesses the words of God, and these words give life to those who accept them. $^{131}$

This life-giving power of Jesus' words is illustrated in the twin healings of 4:46-54 and 5:2-9. In the first, emphasis on the word of Jesus as the instrument of his healing work is given through the report of the father's response ("the man believed the word that Jesus spoke to him", 4:50) and through the three-fold re-iteration of the compact command of Jesus to the father ("your son lives", 4:50, 51,

\footnotetext{
${ }^{129}$ The reference to the Baptist "coming" from God in 1:6, of course, uses $\gamma^{\prime} \nu$ o $\mu \alpha \iota$ not " $\rho \chi 0 \mu \alpha \iota$, in order to put emphasis on John's createdness over against the eternal existence of the Word who always was (角, 1:1).

130 Prologue, 58.

${ }^{131}$ This significance of the words of Jesus is also made explicit at the climax of Jesus' public ministry in which the author presents an "epitomy" of his message throughout the foregoing chapters. See John 12:44-50 and discussion in Brown, John, 491-493; Schnackenburg, John, 2.424-425; Beasley-Murray, John, 207, 217-218; Whitacre, John, 326; Rekha Chennattu, Johannine Discipleship as a Covenant Relationship, (Peabody, MA: Hendrickson, 2006), 79-80.
} 
53). ${ }^{132}$ The subsequent account similarly emphasizes the instrumentality of the compact 'word' of Jesus to the paralytic both in the healing account itself $(5: 8-9)$ as well as in the following dispute with the religious leaders (5:11-12) and the explanatory discourse $(5: 24-25,28-29) .{ }^{133}$ The statement of 3:34, $\tau \dot{\alpha}$

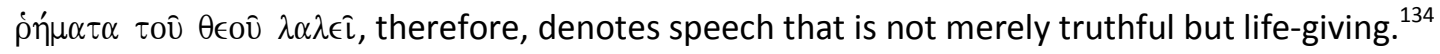

In summary, that which Jesus brings is not only of a different order of magnitude, it is of a whole different order of being from that brought by John. This is the reason why John deploys the strongest possible metaphors to explicate the difference in status between himself and the One to whom he directed all attention. ${ }^{135}$ This is also why his final words to his disciples conclude quite simply, "He must increase, but I must decrease" (3:30). If John is merely a voice announcing the coming Lord, Jesus is the Lord himself (cf. the confession of Thomas, 20:28). If John baptizes with water "in order to reveal to Israel...the one who baptizes with the Holy Spirit" $(1: 31,33)$, Jesus baptizes with the Holy Spirit in order to impart new life from the dead (3:3-8, 34-36; cf. 4:10-14; 6:33, 35, 62-63). "In short, this passage [3:31-36] is a commentary on 1:18: Only the Son, who is in the Father's lap, has made God known because his unique derivation qualifies him to do so."136

\section{C.ii.3. John 4:1-42}

I have been arguing that John 2:1-11 and 3:22-36 correlate marriage imagery, water imagery and the nearing of Jesus' "hour" in order to present Jesus as the messianic bridegroom of Israel. Moreover, I have sought to highlight the interplay between the messianic bridegroom motif and the role of Judaism in these passages. I will now address 4:1-42 in order to complete my survey of the "wedding" passages of John 2-4. ${ }^{137}$

Jesus' encounter with the Samaritan woman takes the form of a wedding type-scene in which Jesus announces the coming gift of living water which, in turn, forms the basis of the true worship "the Father seeks". A number of commentators have noted the resonances of John 4 with the Old Testament wedding or betrothal type-scene. The account of a man journeying to a foreign land, arriving at a well

\footnotetext{
${ }^{132}$ See further, Feuillet, Studies, 30; Lindars, John, 204; Keener, John, 633; Ridderbos, John, 176-177.

${ }^{133}$ Cf. Beasley-Murray, John, 72-73.

${ }^{134}$ For this reason, it is of Jesus not John that it is said belief leads to eternal life $(3: 15,36)$.

${ }^{135}$ In addition to the metaphor of the friend of the bridegroom at 3:29, recall the equally potent metaphors used earlier by John of a voice (1:23; contrast the form of the citation in the Synoptics) and an unworthy slave (1:27).

${ }^{136}$ Leander E. Keck, "Derivation as Destiny: 'Of-ness' in Johannine Christology, Anthropology and Soteriology," in Exploring the Gospel of John: In Honor of D. Moody Smith (eds. R. Alan Culpepper and C. Clifton Black; Louisville: Westminster John Knox, 1996) 278.

${ }^{137}$ For full-length treatment of John 4:1-42 see Teresa Okure, The Johannine Approach to Mission: A Contextual Study of John 4:1-42 (Wissenschaftliche Untersuchungen Zum Neuen Testament; Tübingen: Mohr, 1988), and Olsson, Structure; for succinct discussion of structure and themes in the chapter see Coloe, Dwells, 85-114.
} 
where he encounters a woman with whom he has a conversation and gives or receives a drink, and finally marries the woman or betroths her to another occurs repeatedly in the patriarchal and Exodus narratives. ${ }^{138}$ Evidently, Evangelist has composed the account in such a way as to evoke this formal background. ${ }^{139}$

The conversation begins with the matter of water (4:7-14). The narrative presents Jesus as "greater" $(\mu \in i \zeta \omega \nu)$ than the patriarch Jacob who gave the Samaritans the well at Sychar because he brings the "gift of God", that is, water of the sort that slakes the thirst of humanity in a way that Jacob's well never could. ${ }^{140}$ After the exchange about the woman's past, the conversation turns to the question of proper worship (4:20-26). Though Jesus expressly rejects the worship of the Samaritans as based in ignorance and commends that of the Jews as based in right knowledge (4:22), both forms of worship must now give way to the worship obligatory for all "true worshippers" from now on. With the stark "but an hour is coming and now is" of 4:23, Jesus declares the arrival of the time of messianic salvation (4:25-26) and with it the necessity of worshipping the Father "in Spirit and truth". ${ }^{141}$ Thus, similar to John 2:1-11 and 3:22-30, Jesus' dialogue with the Samaritan woman sets forth Jesus as the long-awaited messianic bridegroom whose presence signals the arrival of the eschatological "gift of God", the salvation of the world (cf. 4:42).

What, then, is the contribution of this passage to the issue of Judaism as it relates to the ministry of Jesus? I suggest important evidence is found at three points in the narrative: the contrast between water from Jacob's well and the "living water" Jesus brings; the contrast between contemporary Jewish worship and worship "in spirit and truth"; and the harvest metaphor in 4:35-38.

\footnotetext{
${ }^{138}$ Gen 24:1-67; 29:1-20; Exod 2:15-22. The retelling of the account of Moses in Josephus (Ant. 2.257) has also been supposed to attest a tradition which stands behind John 4.

${ }^{139}$ Keener, John, 586, calls these "allusions...difficult to miss." For up-to-date bibliography and incisive discussion, see esp. Michael W. Martin, "Betrothal Journey Narratives," CBQ 70 (2008): 505-523; and McWhirter, Bridegroom, 58-76, who settles on Gen 29 as the primary background, concluding, "John borrows details from Gen 29 to reveal Jesus as the Jewish messiah who offers eternal life to apostate Samaritans." See, also, Duke, Irony, 101-103. Okure, Mission, 87-88, registers a cautionary note owing to the lack of precise verbal parallels with any of the Old Testament backgrounds as well as the fact that Jesus and the Samaritan woman do not marry. However, it is not verbal parallels but formal parallels that establish the connection (see the analyses of McWhirter and Martin cited above), and Jesus may indeed be depicted as entering into a symbolic marriage with the Samaritan townspeople (see esp. Martin, "Betrothal", 520-523).

${ }^{140}$ Drawing on the evidence of Ezekiel the Tragedian, William Horbury, "The Gifts of God in Ezekiel the Tragedian," in Messianism Among Jews and Christians: Twelve Biblical and Historical Studies (ed. William Horbury; London: T \& T Clark, 2003) 65-82, 69-70, shows "the gift of God" most likely refers to the Jewish hope for messianic deliverance.

${ }^{141}$ The use of temporal markers to underscore the arrival of the messianic salvation also occurs at 4:35 ('є $\tau$... $\left.\eta_{\eta} \delta \eta\right)$. Olsson, Structure, 251.
} 
I noted above how John 4:10-14 recounts Jesus' conversation with the woman at the well of Jacob in a way which juxtaposes the gift of the Patriarch with the gift Jesus offers. ${ }^{142}$ Whereas the water the woman sought to draw from Jacob's well would quench her thirst for only a short time, that which Jesus offers slakes her thirst permanently (4:13-14). Manifestly, the water Jesus offers is not physical water like that from Jacob's well, but water of an altogether different nature. ${ }^{143}$ The distinction between the two waters turns on the word "living" ( $\zeta \hat{\omega} v, 4: 10)$.

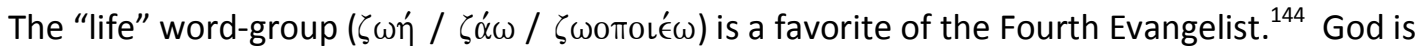
the fountain of all life (cf. 5:26) and Jesus, as the eternal Word, likewise possesses life intrinsically (1:4). The gift of divine life was delegated to the Son to be given to the world, or those whom the Father gave to the Son $(5: 26 ; 6: 39-40 ; 17: 2)$, and is so given by the agency of the Holy Spirit $(3: 3-8 ; 6: 63 ; 7: 37-39)$. Interestingly, the triune shape of the activity of "giving life" is indicated by the threefold use of the rare $\zeta \omega 0 \pi$ ol $\epsilon \omega$, predicated once each of the Father, the Son and the Holy Spirit (respectively, 5:21 [2x]; 6:63). The nature of this gift of life receives further clarification in the prayer of Jesus to the Father at 17:3 where he states, "this is eternal life, that they may know you, the only true God, and Jesus Christ whom you sent." The gift of life given by God to humanity ("eternal life"), then, is entrance into fellowship with the divine life of the Father, Son and Spirit.

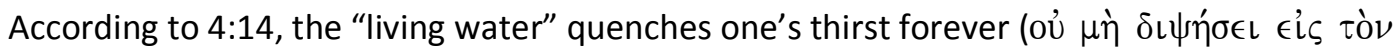

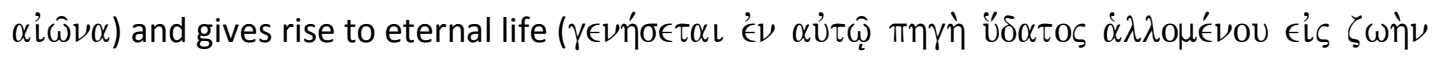
$\alpha \iota \omega ́ v\llcorner O \nu)$. This shows that the adjective "living" (4:10) speaks of the quality of the water whereby it imparts life to those who drink. Therefore, consistent with John's use of water-symbolism elsewhere (cf. 1:33; 3:3-8; 7:37-39) the "living water" which Jesus gives is the Spirit of God in his life-giving activity. $^{145}$

It is worth pausing here to make an observation concerning the contrast between the water from Jacob's well and the "living water" supplied by Jesus. Commentators sometimes emphasize the redemptive-historical orientation of the contrast. ${ }^{146}$ This observation is accurate inasmuch as Jesus in no way derides the past provision of the patriarch but signals, instead, the dawning of a new age. In a

\footnotetext{
142 "Jesus' superiority to Jacob is central to the story" (Keener, John, 601). The contrast may also implicitly include reference to the 'gift of Moses', that is, Torah. See Keener, John, 602-603; Olsson, Structure, 162-173, 179, 182.

${ }^{143}$ Keener, John, 604.

${ }^{144}$ Fifty-six uses in John versus thirty-four uses in the Synoptics combined.

${ }^{145}$ Brown, John, 179. A number of scholars argue for the presence of Isa 44, Ezek 36, 47 and Zec 14 in John 4:14. See esp. Um, Temple, 133-146; Keener, John, 604-605; Gary T. Manning, Echoes of a Prophet: The Use of Ezekiel in the Gospel of John and in the Literature of the Second Temple Period (Journal for the Study of the New Testament Supplement Series, 270; London: T \& T Clark, 2004), 186-189.

${ }^{146}$ Exemplary, in this regard, is Ridderbos, John, 157.
} 
manner analogous to the manna in the Bread of Life discourse, what was long hoped for ("the gift of God", 4:10) has now arrived and the past provision, by comparison with the new, is no longer adequate. ${ }^{147}$ It appears the water of Jacob's well functions in a manner analogous to the original wine of 2:1-11 which is not derided or condemned as having failed, but nevertheless judged as vastly inferior to the new provision from Jesus. Importantly, an eschatological framework governs both contexts indicating that the inadequacy of what came before is a function of the arrival of the eschatological gift (i.e., no inadequacy is implied regarding the former provision prior to the coming of Jesus).

Proponents of this view err, however, in rejecting an ontological contrast between the past provision and the eschatological provision. ${ }^{148}$ On the contrary, an ontological contrast is precisely what is in view in the use of the key term "living" (4:10). The "living water" Jesus gives is the Spirit of God who imparts eternal life. Manifestly, the same cannot be said of the patriarch Jacob or his well. In this sense, recognition of an ontological contrast between the two waters is unavoidable. From the first stage of the dialogue between Jesus and the Samaritan woman, then, the Evangelist indicates that the nature of the contrast between the salvation Jesus brings and all that came before is both eschatological and ontological. With the arrival of the messiah who brings the "gift of God", the former provision of the patriarch finds its "telos" in the life-giving Spirit of God, a provision of a different order of being.

The second portion of the narrative which yields important evidence for the Gospel's view of Judaism in relation to Jesus is 4:20-24. Jesus declares to the Samaritan woman that over against the (false) worship at Gerizim and the (true and proper) worship at Jerusalem, "the hour is coming and now is when true worshippers will worship the Father in spirit and truth" (4:23). Jesus draws an eschatological contrast between the worship offered at the Jerusalem Temple (in which he participates!) and the worship which he makes possible through his messianic ministry. The shift in focus from the old to the new is made emphatically clear both by the words "neither on this mountain nor in Jerusalem" (4:21) as well as by the strong contrastive $\dot{\alpha} \lambda \lambda \dot{\alpha}$ in 4:23. That which came before, both Jewish and Samaritan worship, gives way before the eschatological worship established by Jesus. Here again, therefore, the Evangelist contrasts the old and the new in redemptive-historical terms.

\footnotetext{
${ }^{147}$ Cf., e.g., John 6:48-50. Ridderbos notes that the Old Testament evinces an awareness of the need for the "spiritual water" when it describes "what the people in their distress desired from God" (citing Psalms such as 42:1 and 36:9 as well as Isa 55:1-2; Jer 2:13).

${ }^{148}$ E.g., Ridderbos, John, 157, states, "the terms 'living', 'true', 'good' and the like are rooted theologically, not in an ontological contrast between illusion and reality, but in a salvation-historical contrast." Of course, the language of "illusion" is a caricature of the ontological view. The terms "symbolic" or "typological" more suitably represent the outlook of the Evangelist who portrays all that came before Jesus in God's salvific design not only as real but as gracious (1:16-17).
} 
Nevertheless, as in 4:7-14, the contrast entails more than merely temporal progression or succession. The contrast between Judaism and the new worship "the Father seeks" is a contrast between different orders of being. Ridderbos captures it well: "Spirit and truth refer to the fellowship thus established in its life-creating and life-giving power, as leading to the fullness of God's gifts (cf. 1:16) that is no longer mediated by all sorts of provisional and symbolic forms, but by the Spirit of God himself ${ }^{\prime 149}$

This ontological contrast receives further explication in the statement, "God is spirit and those who worship him must worship in spirit and truth". I will treat this much-discussed passage in two parts: the meaning of the clause "God is spirit", and the meaning of worship "in spirit and truth".

Stephen Um has examined a wide range of second Temple literature to show that the designation of God as $\pi \nu \in \hat{U} \mu \alpha$ carried the idea not only of ontology but also of identity. ${ }^{150}$ " "God is Spirit' is not only a definition of the so-called nature of God but also a description of the eternal divine identity of God." More specifically, the expression describes "God's dynamic attribute of being the source of all life, relating his life-giving power to human beings."

Among the passages Um adduces is 4 Ezra 6:39-41.

I said, "O Lord, you spoke at the beginning of creation, and said on the first day, 'Let heaven and earth be made', and your word accomplished the work. And then the Spirit was hovering, and darkness and silence embraced everything; the sound of man's voice was not yet there. Then you commanded that a ray of light be brought forth from your treasuries, so that your works might then appear.'

\footnotetext{
${ }^{149}$ Ridderbos, John, 164 (italics mine); cf. also Andreas J. Köstenberger, "Destruction of the Second Temple and the Composition of the Fourth Gospel," TrinJ 26 (2005) 235-236. This idea corresponds closely to 3:31-36 where the stark distinction between Jesus and the Baptist flows from the different origins of the men. John was "from the earth" and therefore limited in the content and forms of his ministry to the things of the earth in all their finitude; Jesus is "from above" and so brings about the fullness of the salvation signified by the witness of John. Kierspel argues that this redemptive-historical shift from the the outward and physical to the inward and spiritual is the central governing concept throughout John 2-4 and that this is made evident from the structuration of the chapters as a whole. See "Dematerializing", 550-553.

${ }^{150}$ Um, Temple, 76-129.

${ }^{151}$ Um, Temple, 171. Note the very similar thought of Brown, John, 172 (followed by Olsson, Structure, 189, and Coloe, Dwells, 102) and Ridderbos, 164. Throughout his summative discussion of John 4:23-24 (pp. 170-178) Um relies heavily on the works of Bauckham, God Crucified, and Kevin Vanhoozer, "Does the Trinity Belong in a Theology of Religions?" in The Trinity in a Pluralistic Age: Theological Essays on Culture and Religion (ed. Kevin Vanhoozer; Grand Rapids: Eerdmans, 1997) 41-71.
} 
The Spirit of God is the power by which the "word accomplished the work" of creating the heaven and earth. ${ }^{152}$ This creative work of the Spirit of God in Jewish thought also surfaces in Jdt 16:1314,

I will sing to my God a new song: O Lord, you are great and glorious, wonderful in strength, invincible. Let all your creatures serve you, for you spoke, and they were made. You sent forth your spirit and it formed them; there is none that can resist your voice.

In his treatment of this passage, Um highlights the several allusions to Old Testament creation texts (including, especially, Pss 33:6 and 104:30) in which the Spirit of God is operative as the power by which all life, particularly human life, becomes possible. For Judith, here, $\pi \nu \in \hat{v} \mu \alpha$ designates the lifegiving power of God that creates life. ${ }^{153}$

Jewish tradition could associate the Spirit of God with the power of God's work of eschatological new creation as well as with the original creation. For example, in the well-known scene of the seven brothers before Antiochus IV in 2 Macc 7, the author likely drew upon Old Testament texts depicting the work of the Spirit (or breath) of God in both the original creation (Gen 2:7) and the eschatological resurrection (Ezek 37:5-14). 2 Maccabees 7:22-23 reads,

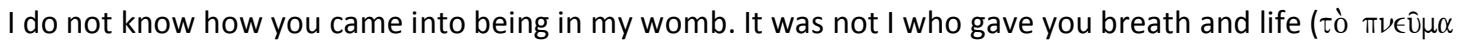

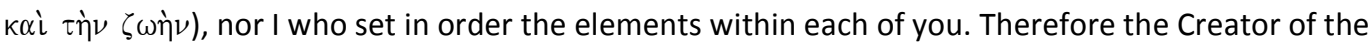
world, who shaped the beginning of man and devised the origin of all things, will in his mercy give breath

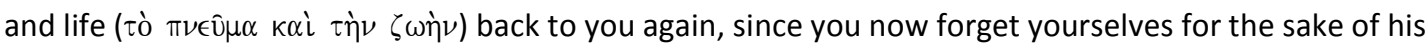
laws.

As Um argues, though the terminology differs somewhat from Gen 2:7 (e.g., the use of $\pi \nu$ ì $\nu$ instead of $\pi \nu \in \hat{v} \mu \alpha$ ) the concepts are clearly synonymous and the author demonstrates awareness of resurrection thought developing in contemporary Judaism. The background in Ezek 37 is particularly informative as it calls the breath given to the dead "my Spirit" ( it, "the very 'Spirit'... of God, who is the source of all life."

\footnotetext{
${ }^{152}$ See discussion in Um, Temple, 77-80.

${ }^{153} \mathrm{Um}$, Temple, 80-82.

${ }^{154}$ Um, Temple, 115-119 (119). In ch. 3, Um also examines L.A.B. 27.10; 36.2; Jos. Asen. 4.7-10; 8.9-11; 12.1; 1QH 8.15, 20; 15.6-9; 2 Bar. 23.5; 4Q521 Frag. 2 Col. 2.6; Wis 15.11; 4 Ezra 3.5.
} 
All this bears on John 4:23-24 by showing that the expression "God is $\pi \nu \in \hat{\nu} \mu \alpha$ " speaks not merely of divine ontology (setting God over against the physical creation), but also of divine identity as the One who gives life to all things. In its Jewish context, the phrase denotes "the living God...the unique selfexistent being in whom both creative and new creative life are to be found."155 Um concludes that this highly Jewish way of conceiving of God (as the unique creator and life-giver) issues in the typically Jewish conclusion that God is therefore the only one worthy of worship.

The second part of Jesus' statement in John 4:24, "those who worship must worship in spirit and truth", flows from the claim of the first clause that God is (life-giving) spirit. The phrase $\epsilon \nu \pi \nu \in \dot{\mu} \mu \alpha \tau \iota$

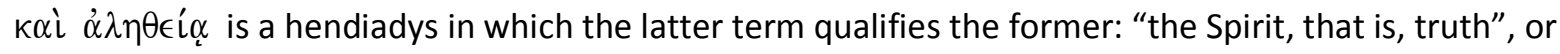
perhaps, "a stylistic variant of the later and clarifying phrase 'Spirit of truth"”. ${ }^{156}$ Here, again, "truth" bears a redemptive-historical import distinguishing the old order of worship from that ushered in now through Jesus. ${ }^{157}$ Thus, taking "in spirit and truth" in this way and maintaining continuity of thought

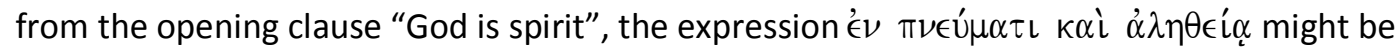
paraphrased, "in the life-giving spirit of God, that is, in the fullness of the eschatological salvation Jesus brings".

It is important to recognize the essentially relational nature of this salvation and worship. ${ }^{158}$ To “worship 'in Spirit and truth' (' $\epsilon \nu \pi \nu \in \dot{\nu} \mu \alpha \tau \iota \kappa \alpha \grave{\alpha} \lambda \lambda \eta \theta \epsilon i \alpha)$ is to share and to be united in God's own eternal life by being identified with the means of that new creational life, which he has revealed in the new eschatological Temple, namely Jesus Christ."159 This last qualification is vital. God's eschatological revelation of "who he is and how he acts in history" is uniquely made in Jesus, the true Temple. ${ }^{160}$ Jesus

\footnotetext{
${ }^{155} \mathrm{Um}$, Temple, 174. The tendency to discard entirely the ontological force of "God is Spirit" in favor of the concept of identity must be avoided. Ultimately, both must be retained equally, as indeed the above words from Um tacitly concede. The discussion in Carson, John, 225, strikes an admirable balance.

${ }^{156}$ Keener, John, 618. So, also, Brown John, 180, Ridderbos, John, 163; Jones, Symbol, 104.

${ }^{157}$ See Ridderbos, John, 157. Context points in this direction as "true worshippers" (4:23) are defined over against those who worship at Gerizim or Jerusalem not in terms of right versus wrong, but by the eschatological formula "but $[\dot{\alpha} \lambda \lambda \dot{\alpha}]$ the hour is coming and now is".

${ }^{158}$ E.g., Ridderbos, John, 163-164: “'Spirit and truth' refer to the fellowship thus established in its life-creating and life-giving power".

${ }^{159} \mathrm{Um}$, Temple, 174.

${ }^{160} \mathrm{Um}$ states, "the eschatological, new creational experience of 'who God is' would have been unknowable to people had God not chosen to reveal himself in the person of Jesus Christ, as the one and only true God who exists eternally in himself" (Temple, 174). In similar fashion, Lincoln, John, 177-178, concludes that because Jesus mediates the HS and embodies the truth, the phraseology "in spirit and truth" indicates that all worship centers in Jesus.
} 
is able to make this revelation of who God is because he himself shares in that divine identity. ${ }^{161}$ This is

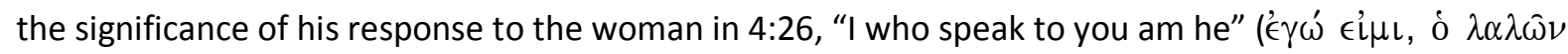

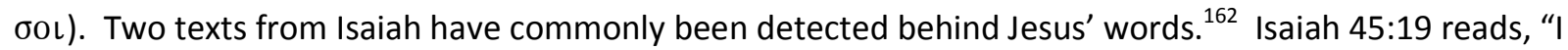
have not spoken in secret, nor in a dark place of the earth: I said not to the seed of Jacob, Seek vanity: I,

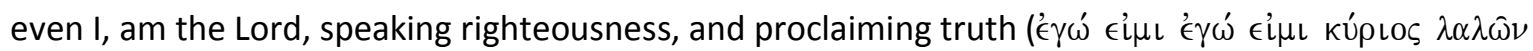

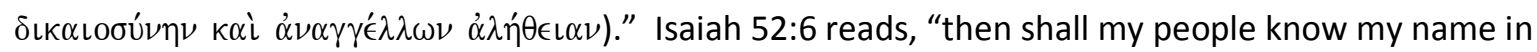

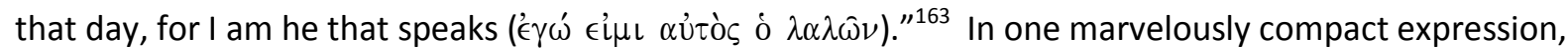
Jesus simultaneously appropriates to himself the title messiah and transcends it. The import of this for the meaning of 4:24 is that it is as God that Jesus reveals who God is and brings people into vital fellowship with the triune God.

All this makes clear how the lines of thought in 4:7-14 and 4:20-26 converge. The eternal life given by Jesus is, at root, entrance into fellowship with the divine life. It is within the context of this eschatological relationship with the life-giving God (that is, "in spirit and truth") that "true worship" must from now on take place. In this way it becomes clear why John portrays Jesus as the goal of Judaism. Judaism is not belittled, nor does it come under judgment. ${ }^{164}$ Rather, like John the Baptist, it must decrease and give way before the advent of the one who shares in the identity of the one true God and so brings the "gift of God" in its fullness. This gift is the Spirit of God who establishes the fellowship with the divine life that gives rise to worship such as was never possible in the old order but was always the goal to which the Father was working. ${ }^{165}$

The final portion of the narrative of John 4 which yields insight into the question of Judaism and its relation to Jesus is verses 34-38. These verses form the second of two references to the ministry of Jesus and his disciples which frame his dialogue with the Samaritan woman (cf. 4:1-2). Indeed, the

${ }^{161}$ The language of "sharing in the divine identity", both here and in Um, derives from the work of Bauckham, God Crucified.

${ }_{162}^{16 . g .,}$ Bernard, John, 1.151; Coloe, Dwells, 102; Lincoln, John, 178; Keener, John, 620.

${ }^{163}$ From this evidence Lincoln, 178, concludes, "There can be little doubt that the formulation of this seventh and climactic contribution of Jesus to the dialogue is meant to point to Jesus' divine identity."

${ }^{164}$ Even the language of "proper worship" (e.g., Brown, John, 180) may be misleading since, once again, 4:22 precludes any evaluation of Jewish worship prior to the time of Jesus as "improper".

${ }^{165} \mathrm{Um}$, Temple, 178, makes this point forcefully in his conclusion: "True worshippers must be empowered by the Spirit of God in order to encounter God in worship, as they respond to the father in exclusive worship by recognizing his divine reality of eschatological life found in the true Temple of God....Therefore, the practice of monolatrous worship was required ('must') because the unique identity of God as the sole Creator of all eschatological life placed him in a distinctive category beyond all other reality. The Spirit in John refers to eschatological life so that it is now as the sole giver of this eschatological life that God is to be worshipped. In other words, because God relates to worshippers with his eschatological identity of self-continuity ('God is Spirit') those who worship need to come to a recognition of the one God by finding eschatological life in the True Temple." 
entire dialogue is set against the growth of the Judean ministry and the corresponding increase in attention from the Jewish authorities. At 3:22 the Evangelist informs the reader that "Jesus came with his disciples into the countryside of Judea and he remained there with them and he was baptizing." The ensuing account about the Baptist arose out of the concern of his disciples over the growing success of Jesus' baptizing activity. As the Evangelist carefully qualifies at 4:2, however, "it was not Jesus himself who was baptizing but his disciples". It is against this wider backdrop of the baptizing ministry of Jesus and his disciples over against that of John and his disciples that Jesus' exchange with his disciples in 4:34-38 must be understood. ${ }^{166}$ Utilizing the metaphor of a harvest, Jesus represents the work he and his disciples are engaged in as "reaping" the "white" fields, that is, as the culmination of the agricultural cycle first set in motion by the sowers. Within this flow of thought the most natural identity to posit for the "sowers" is John the Baptist and his disciples whose baptizing ministry, as we saw in 3:27-30 (and cf. 1:25-33), prepared for the arrival of Jesus and his ministry. This conclusion provides a helpful basis for interpreting the concluding statement by Jesus in 4:38 where Jesus informs his disciples that as they go about the work he gives them they "enter into" the labors of "others" ( $\alpha \lambda \lambda \mathrm{ol})$ who have gone before.

Scholars have debated the identity of the "others" who preceded the disciples of Jesus. ${ }^{167}$ Suggestions range from the Old Testament patriarchs and/or prophets (sometimes including John the Baptist) ${ }^{168}$ to John the Baptist, ${ }^{169}$ the Samaritan woman, ${ }^{170}$ Jesus, ${ }^{171}$ and the Hellenists in Acts 8:4-24 who converted the Samaritans. ${ }^{172}$ In seeking a solution to this question it must first be observed that the contrast between "reapers" and "sowers" in the passage is a contrast in redemptive-historical activity. This is the implication of the temporal idea in 4:35 that the time of harvest has now arrived and the time for laboring as reapers has come. The temporal idea of the arrival of eschatological time has recurred

\footnotetext{
${ }^{166}$ Olsson argues this point at length. See Structure, 135-138, 209-210, 238-239, 254-255.

${ }^{167}$ For a survey of views, see Okure, Mission, 159-164.

${ }^{168}$ Keener, John, 626, cites Irenaeus Against Heresies 4.23.1 as holding this view. Recent proponents include Lagrange, Jean, 121; Lindars, John, 197; Joseph Newbould Sanders, A Commentary on the Gospel according to St. John, edited and completed by B.A. Mastin (Black's New Testament Commentaries; London: Black, 1968), 153; Bruce, John, 115; Carson, John, 231 (who, like Bruce, includes the Baptist as "the last in the succession of prophets").

169 Robinson, “Others”, 510-515, followed by Morris, John, 249.

${ }^{170}$ Many commentators default to this alternative as the most likely given the immediate context of the woman leading the townsfolk out to Jesus (4:29-30). E.g., Keener, John, 626.

${ }^{171}$ Barrett, John, 243; Bernard, John, 1:155 and 2:380 (appealing to Mark 4:3, 14); Wengst, Johannesevangelium, 173.

${ }^{172}$ Oscar Cullmann, "Samaria," in The Early Church (Translated and edited by A.J.B.Higgins; London : SCM Press, 1956) 185-192. Other scholars propose some combination of these alternatives. E.g., Bernard, John, 1.159; Keener, John, 626, and Lincoln, John, 180, regard the plural $\alpha 2 \lambda$ o as likely designating Jesus and the woman; BeasleyMurray, John, 64, and esp. Moloney, Belief, 166-167, argue for John the Baptist and Jesus; Olsson, Structure, 254255, believes "“the woman', John the Baptist and Philip" (from Acts 8) are in view; Okure, Mission, 160-163, proposes Jesus and the Father.
} 
throughout the wedding passages in John 2-4. ${ }^{173}$ More immediately, this temporal perspective appeared in the fulfillment of the water of Jacob's well and of Jewish (and Samaritan) worship with the dawning of the messianic "hour" (4:10-14, 21-24). John 4:35-38, then, is most naturally understood in terms of this temporal scheme such that the sowers belong to the era prior to the coming of the messiah, and the reapers belong to the newly arrived "hour" of salvation. ${ }^{174}$

Moreover, "sowing" is likely not a reference to "sowing God's message", ${ }_{175}$ as in the Synoptic tradition, such that Jesus (or Jesus and the Father, or Jesus and the Samaritan woman) spread the "message" and the disciples "reap" the harvest of converts. The disciples do not merely "reap" converts, but witness and testify exactly as did Jesus (and the Samaritan woman). ${ }^{176}$ The sowing of the gospel witness did not cease with Jesus (or the Samaritan woman) but continued through the ministry of the disciples. ${ }^{177}$ But if Jesus and the disciples perform the same task (witnessing to the Gospel message), it makes little sense to distinguish their labors as "sowing" and "reaping". Jesus should not, then, be included among the sowers in 4:36-37.

If, therefore, the "others" are a group who perform a work both different from and redemptivehistorically antecedent to that performed by Jesus and his disciples, the best candidate for the group is John the Baptist and his disciples. As suggested above, this reading is the most natural within the narrative flow from 3:22. ${ }^{178}$ In addition to the Baptist and his disciples it may be proper to include others in Jewish tradition more generally, such as the patriarchs and prophets. This view has merit in the context of a narrative that portrays the "gift" of Jesus over against that of the patriarch Jacob and

${ }^{173}$ E.g., John 2:4-10; 3:27-29.

${ }^{174}$ For the Old Testament background of this image, see esp. Coloe, Dwells, 96, 108-110.

${ }^{175}$ Keener, John, 625, citing Mark 4:3; 12:1-12; Matt 13:24.

${ }^{176}$ If the Jesus is to be identified with the "reaper" of 4:36, it is inconsistent to identify him two verses later with the "others" who sow. It is far preferable to identify Jesus with the eschatological activity of reaping throughout the passage and so to regard his activity as the same as that of his disciples.

${ }_{177}$ Cf. 20:21, "as the Father sent me, so I am sending you" (also 17:18). Andreas J. Köstenberger, The missions of Jesus and the disciples according to the Fourth Gospel : with implications for the Fourth Gospel's purpose and the mission of the contemporary church (Grand Rapids, Mich.: W.B. Eerdmans, 1998), 181, believes 4:34 (the sending of Jesus by the Father) forms an inclusio with 4:38 (the sending of the disciples by Jesus) in anticipation of 20:21. The continuity between the mission of Jesus and that of his disciples is also apparent in the application to both of the metaphor of "bearing fruit". Cf. 12:24 (which characterizes both Jesus' cross [12:23] and the nature of discipleship [12:25-26]); 15:5, 8, 16; and see discussion in Olsson, Structure, 247-248 (who sees this as "Jesus' continued mission through his disciples") and Köstenberger, Missions, 133, and more generally on 180-198.

${ }^{178}$ As noted above, some believe the immediate context (4:29-30) prompts inclusion of the Samaritan woman, as well. I believe this is mistaken because her of representative function in the narrative (on which see Koester, Symbolism, 49-50, and esp. McWhirter, Bridegroom, 67-72, 76). As representative of the Samaritan people (in a manner analogous to Nicodemus' representation of the Jews in John 3), her encounter with Jesus and subsequent faith and witnessing activity corresponds to the 'reapers' rather than the sowers. That is, she belongs to the same side of the redemptive-historical divide as Jesus' disciples (contra Olsson, Structure, 254-255). The immediate context of 4:29-30, then, serves as paradigmatic for the activity to which Jesus calls the disciples in 4:35-38 (cf. the invitation to "come and see" at 4:29 with the invitation by Jesus and his first disciples at 1:39, 46). 
also makes the express claim that "salvation is from the Jews" (4:22) thereby evincing concern for a redemptive-historical view of God's salvation in which some, at least, of the Jewish people play a role in the realization of God's work of salvation. ${ }^{179}$ By way of conclusion, then, the harvest metaphor in John 4:35-38 portrays not the disciples of Jesus succeeding the labors of Jesus and the Samaritan woman, but Jesus and his disciples succeeding the labors of the Baptist and his disciples (and, perhaps, also the patriarchs and prophets of Jewish tradition generally).

This metaphorical conceptualization of the ministry of Jesus in relation to the work of John (and of those who came before him) illustrates once more both the continuity and discontinuity between Jesus and Judaism in the Fourth Gospel. The continuity is beautifully represented by the image of harvesters entering the field to work alongside the sowers who have labored up to that time. The workers are all engaged in the same enterprise (the production of a crop) and so they "rejoice together" at the success and completion of their work. Yet, there is also discontinuity, for their labors are separate and distinct. Though Jesus and his disciples enter into ( $\epsilon i \varsigma . . \in \ell \in \in \rho \chi 0 \mu \alpha L, 4: 38)$ the labors of the sowers and for a time work alongside them, ${ }^{180}$ the work of the harvesters nevertheless belongs to a subsequent stage in the process. It is, in fact, climactic in nature and so is said to bring to completion ( $\tau \in \lambda \in \operatorname{ló} \omega, 4: 34$ ) all that God was doing up to that time.

\section{C.iii. Summary of findings: Jesus and Judaism in the 'messianic bridegroom' passages}

I am now in a position to step back and consider the contributions of the "bridegroom" passages in John 2-4 to the role of Judaism in the Fourth Gospel. The above survey of John 2:1-11, 3:22-36 and 4:1-42 has made clear how Judaism is viewed positively in relation to Jesus, how it is limited in relation to Jesus, and how the Evangelist conceives of the nature of the contrast between Jesus and Judaism.

The positive light in which the Jewish religion is portrayed appears in the instrumentality of the institutions of Judaism in the realization of the salvation Jesus brings. I argued for this reading of the wedding at Cana in which the jars used for ritual purification "of the Jews" are set in the center of the

\footnotetext{
${ }^{179}$ Carson, John, 231, and Köstenberger, Missions, 183, note this, as well. The assertion of Bultmann, John, 199 n.2, that "there can be no question here of any reference to the prophets of the OT...; a correlation of Jesus and the prophets would be quite contrary to the Johannine view", is belied by the function of the prophets in the Fourth Gospel as preparatory witnesses to Jesus in the same manner as Moses and John the Baptist. Cf. esp. 1:45; 12:41; and note the Old Testament prophetic shape of the characterization of the Baptist in 1:23 (on which see Williams, "Testimony", 110-111). Wengst, Johannesevangelium, 173, reasons along the same lines when he concludes, "Und Jesus selbst und seine Schüler stehen ihrerseits in der Traditionskette Israels, was auch das Johannesevangelium auf Schritt und Tritt belegt. Diese Traditionskette ist nicht abgebrochen, sondern neben der Kirche weitergegangen".

${ }^{180}$ An image indicative of an abundance of harvest in the Old Testament. Cf. Amos 9:13, "the days are coming when the plowman shall overtake the reaper and the treader of grapes him who sows the seed." See Brown, John, 182.
} 
miracle account and employed by Jesus in meeting the need of the wedding. John 4:22 displays most emphatically the exalted status of Jewish religion, and indeed of the Jews. In Jesus' frank pronouncement, "salvation is from ('€к) the Jews", the Jews are made the source of salvation in the sense that it is from the Jews, and not any other people group, that God will bring his salvation into the world. Moreover, the logical relationship ("for") between the two final clauses of 4:22 forges an intimate link between the religious system of the Jews (which centered on the Jerusalem Temple with all its attendant festivals, sacrifices and Sabbaths) and the salvation of the world which God was to bring "from the Jews." Jewish religion will play an instrumental role in the salvation brought by Jesus.

The positive perspective on Judaism is also manifest in the great continuity between the ministry of Jesus and his Jewish predecessors as illustrated by the harvest metaphor Jesus uses at 4:3438. Jesus represents John the Baptist and his disciples (and perhaps the patriarchs and prophets) as sowers and himself and his disciples as reapers. For the purposes of this chapter, the most striking feature of this metaphor is that it makes Jesus and his disciples part of the same enterprise as the "others" who came before. Both groups of laborers work toward the same end, even if they occupy distinct stages of the process.

In addition to representing Judaism in its positive functions, the wedding passages also depict the limitations of Judaism. Notwithstanding its exalted status and purpose, Judaism was nevertheless limited in the scope of its ability to contribute to the realization of God's work in the world. Illustrative, in this regard, is 2:1-11 where the jars as representative of Jewish religion could not meet the need of the wedding in and of themselves. Though instrumental to Jesus in supplying the need of the wedding, the special work of Jesus was requisite for the meeting of the need. Similarly, the well of the patriarch in 4:12-14 was limited in its capacity to deal with human thirst. For, much as it might meet the need of physical thirst for a time, yet it could not meet the deeper need of eternal life for which all humanity thirsts. Further on in the same context the stark contrastive $\dot{\alpha} \lambda \lambda \dot{\alpha}(4: 23)$ indicates the end of Jewish worship as it was previously practiced as a result of the coming of Jesus and the "worship in spirit and truth" he has made available. ${ }^{181}$

This limitation of Judaism implies no deficiency or failure, however, for it was never intended to effect the salvation Jesus brought. Thus, for example, it is a mistake to read the miracle at Cana as a critique of Judaism as though it were a failure. In similar fashion, the friend of the bridegroom, though occupying a prestigious position, is never intended to marry the bride. Rather, "the one who has the

\footnotetext{
${ }^{181}$ In similar fashion, the self-characterization of the Baptist as the Isaianic "voice" has the effect of reducing John and his water-baptism to an instrument for revealing the messiah to Israel (1:31).
} 
bride is the bridegroom". It makes little sense to speak of the "failure" of the friend to marry the bride. Thus, Judaism never could accomplish God's salvation in the world because this was not its purpose.

Finally, if the wedding passages in John 2-4 portray Judaism in both continuity and discontinuity with Jesus they also explain the nature of the distinction. John 3:31-36 and 4:20-24 indicate that the superiority of Jesus is not merely a matter of redemptive-historical location but of ontology and identity. Jesus is superior to John the Baptist and Judaism generally as one who comes from heaven and so is uniquely able to witness to and bring people into fellowship with the life-giving God through the Holy Spirit. The temple, its system of worship and Jewish religion in general were God-sent institutions intended to witness to and prepare for the advent of this salvation in Jesus. They were always limited due to their earthly origins and modes of operation and so could no more accomplish the salvation God planned for the world than John the Baptist could confer eternal life by his water baptism. The accomplishment of eschatological salvation was always to be the peculiar task of the Son of God. ${ }^{182}$

\section{C.iv. Conclusion: John 2-4 as a reprise of the "grace instead of grace" pattern of 1:16-17}

I wish to conclude by suggesting that the basic contours of the relationship between Jesus and Judaism highlighted in my analysis of John 2-4 above coincide with the pattern of thought in John 1:1617. The Johannine formulation $\chi \alpha \dot{\alpha} \rho \iota \nu \dot{\alpha} \nu \tau \grave{\imath} \chi \alpha \dot{\alpha} \rho \iota \tau o \varsigma$ conveys in compact form the idea that the Law given through Moses was a glorious yet provisional revelation of the grace of God but that the incarnation and death of the Son of God was a full revelation of divine grace which brought about salvation for the world. The Prologue does not spell out in further detail what is entailed in this relationship, but I suggest this is precisely what we have seen in the wedding passages of John 2-4.

The "grace instead of grace" conceptual framework recurs throughout these passages and receives important development. For example, in the wedding at Cana, though the first wine was evidently quite good (as the comment of the steward assumes), the wine provided by Jesus was vastly superior. In this sense, the climactic pronouncement of the steward in 2:10 might well be said to contrast "good wine instead of good wine." The force of the statement lies not in the condemnation of the former wine but in the insistence of its inadequacy in view of the new wine. This pattern of thought is also in evidence in the contrast between the ministries of John the Baptist and Jesus. The ministry of John, both in his witnessing activity and baptizing activity, prepares for and is completed by the ministry of Jesus which brings the fullness of salvation to which John merely pointed. I argued that the contrast

\footnotetext{
${ }^{182}$ I highlighted this very Johannine view of the Law at the outset of this chapter. Whether Moses (1:45; 5:46), Isaiah (12:41), Abraham (8:56), "the prophets" (1:45), or "the scriptures" generally (5:39), all wrote about Jesus and envisioned him as the ultimate object of their manifold witnesses.
} 
between the two men does not imply that the witness ("light") of John was false or that his baptism failed to accomplish that for which it was intended. A more accurate conceptualization of the contrast is articulated in compact form at 1:16-17. In relation to the water baptism of John the Baptist, the Spirit baptism Jesus performs might be represented as "baptism instead of baptism". In relation to the earthly testimony of the Baptist, the heavenly testimony of Jesus (3:31-32) may be represented as "light instead of light" (cf. 5:35). Finally, the words of Jesus to the Samaritan woman affirm the goodness and propriety of Jewish worship, in which he participated (4:22). Yet, most emphatically $(\dot{\alpha} \lambda \lambda \dot{\alpha})$ the succeeding verse insists that this worship is now obsolete in light of the arrival of worship "in Spirit and truth". Once more, then, the relationship may be regarded as one of grace instead of grace: the worship Jesus introduces is "worship instead of worship."

\section{Sabbath Controversies}

Up to this point I have addressed the question of Judaism in the Fourth Gospel by focusing narrowly on chapters 2-4. This is because scholarly discussions of the matter commonly emphasize other portions of the Gospel narrative while largely overlooking important material in these chapters. I have not tried to review all facets of the question of Judaism in John but only to fill an apparent lacuna in the research by tracing the development of the bridegroom messiah motif and its bearing on John's representation of Judaism in relation to Jesus. Nevertheless, one additional dimension of Judaism in the Fourth Gospel, specifically the Sabbath controversies, must be addressed since it could potentially be adduced as evidence of a negative attitude toward the Law on the part of Jesus.

Twice in the Gospel Jesus performs healing miracles on the Sabbath and so is accused by the Jewish leaders of breaking the Sabbath. In John 5 Jesus restores full health to a paralytic on the Sabbath (5:9) and the healed man is promptly rebuked by the leaders for carrying his mat on the Sabbath $(5: 10)$. This leads to the discovery that Jesus performed the healing on the Sabbath, and so to official "pursuit"

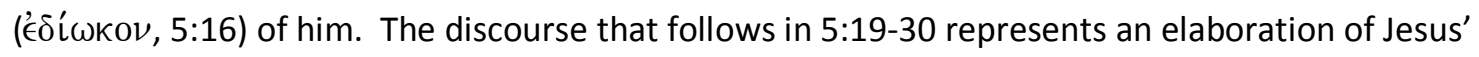
defense of his actions on the Sabbath encapsulated in 5:17. In a word, Jesus denies that he has violated the Sabbath because, like his Father, it is his prerogative to give life and judge even on the Sabbath. ${ }^{183}$ In chapter 9, Jesus restores sight to a man born blind, again on the Sabbath (9:6). The Jewish leaders again respond by accusing him of breaking the Sabbath (9:16) and so of being a "sinner". The subsequent confrontation unfolds along different lines than in chapter 5 and the healed man himself

\footnotetext{
${ }^{183}$ Cf. Richard Bauckham, "Monotheism and Christology in the Gospel of John," in Contours of Christology in the New Testament (ed. Richard N. Longenecker; Grand Rapids: Eerdmans, 2005) 152-153; Keener, John, 650-652.
} 
vindicates Jesus of the charge (9:31-33). Reasoning from the certainty and magnitude of the healing performed the man concludes that Jesus could not be a sinner since he would, in that event, be incapable of the kind of healing the blind man has experienced. Though John leaves the conclusion regarding the Sabbath implicit, the logic of verses 31-33 points to the innocence of Jesus regarding the initial charge of Sabbath-breaking.

Neither of these episodes, then, display a negative or even cavalier attitude toward the importance of Sabbath observance. The contemporaries and eyewitnesses of these events undoubtedly regarded the actions of Jesus as unlawful (though recall the "division" on this point in 9:16). Indicative of their error, however, (at least from the perspective of the Evangelist) is the fact that Jesus appeals to Moses and the Law in his defense (cf. 5:39, 45-47). ${ }^{184}$ Here again, therefore, Jesus does not flout the Sabbath with a view toward setting it aside. His posture toward Sabbath observance is determined less by any concept of redemptive-historical succession than by concern for the revelation of his identity. He performs these works of healing on the Sabbath in order to indicate symbolically something about his identity and mission: namely, Jesus does the work that only God can do.

\section{E. Conclusion}

The burden of the foregoing analysis has been to show that the Fourth Gospel (at least chapters 1-4) represents Judaism as both legitimate and essential to God's plan for world salvation and yet limited in its capacity to contribute to this salvation. In the divine economy the purpose of Jewish religion was essentially prophetic and revelatory. ${ }^{185}$ It was a gracious gift (1:16) meant to point to the coming messiah $(1: 45 ; 5: 46)$ and indeed would find its fulfillment in the arrival of the messianic salvation $(1: 17 ; 3: 29-30)$. For John, the institutions of contemporary Judaism represented living prophecies that Jesus entered into and brought to consummation. For this reason, all that preceded Jesus in God's work in the world "must become less." Herein lies the force of the "grace instead of grace" pattern: it asserts the superiority of Jesus and the salvation he brings without mitigating in any way the legitimacy, honor and importance of the institutions and ministries which preceded and prepared the way for him.

It must be made clear, at this point, that the affirmation of the goodness and legitimacy of Judaism in the Fourth Gospel does not relativize the salvation brought about by Jesus as though the continuation of traditional Jewish religion after the completion of Jesus' work is perfectly acceptable and legitimate. Clearly, John does not see Judaism as it was practiced prior to Jesus as valid after Jesus'

\footnotetext{
${ }^{184}$ See Whitacre, Polemic, 26; Keener, John, 641.

${ }^{185}$ Cf. Pancaro, Law, 528.
} 
death and resurrection. ${ }^{186}$ This, of course, represents one of the most incendiary dimensions of the topic of Judaism in the Fourth Gospel. The matter is further complicated by use of the terms "replacement" or "supersession" in regard to Judaism. ${ }^{187}$ But this language misrepresents the thought of the Fourth Gospel. Commenting on John 2:18-21, Dennis puts the issue this way:

\begin{abstract}
I remain unconvinced that "replacement" is the best description of what is going on here. One of the problems is that the term "replacement" often (explicitly or implicitly) implies some kind of critique or polemic against the Jerusalem Temple (and its institutions) as such, a polemic that I do not believe is part of John's point. Neusner's comments illustrate a fairly severe form of this interpretation: Jesus' action in the Temple "represents an act of the rejection of the most important rite of the Israelite cult...and therefore, a statement that there is a means of atonement other than the daily whole-offering which now is null" ("Money-Changers" 290). The fact that Jesus is the true Temple (and all this implies) in no way means that John (or Jesus!) rejected the Temple as such. The issue in the Temple pericope (and other key places in John) is that Jesus is presented as the true fulfillment of that which the Temple (and its institutions) always really pointed to. ${ }^{188}$
\end{abstract}

Dennis puts his finger on a point that flows naturally from my argument above: insofar as the language of "replacement" or "supersession" implies a negative valuation of Judaism it misrepresents the message of the Fourth Gospel. Beyond the possibility of negative connotations, however, this terminology fails to capture the nature of the relationship between Judaism and Jesus with adequate precision. The matter becomes clear when the distinction is maintained between the institutions of the Jewish religion as the divinely intended means of salvation (whether for Jews or the whole world), versus regarding them as preparatory for the revelation of eschatological salvation. On the former interpretation of divine purpose the salvation revealed in Jesus might well be viewed as a judgment upon Judaism for failing to accomplish this salvation previously. On the latter interpretation of divine purpose no judgment or failure of the religion or its institutions is implied, but rather is precluded (once again, the analogy of the Baptist as the friend of the bridegroom is apt). It is this latter view of Judaism as preparatory that I have argued is evinced in the Fourth Gospel. For this reason, the language of "fulfillment" more precisely represents the relationship between Judaism and Jesus. Jesus came not to

\footnotetext{
${ }^{186}$ See, here, esp. Pancaro, Law, 525-526.

${ }^{187}$ E.g. Carson, John, 133.

${ }^{188}$ Gathering, 176 n. 284 (italics mine); cf. also 166 n. 233.
} 
cast aside or even replace but to "fill up to the top" the institutions of Judaism. ${ }^{189}$ For salvation "is from the Jews". Jesus represents the "eschatological apex" of Temple worship ${ }^{190}$ and so belief in him forms "the logical climax of Judaism". 191

In the chapters that follow I will analyze the way in which John draws upon the symbolism and customs of the annual Jewish festivals in his presentation of Jesus. This concept of the eschatological fulfillment of what was prefigured in and prepared for by the institutions of Judaism will be shown to be in evidence in all three of the festivals.

\footnotetext{
${ }^{189}$ Whitacre, John, 61, (commenting on John 1:17) wrestles with terminology in a similar way. He observes, "Many would say, therefore, that John presents Jesus as replacing Judaism. In a sense this is true. If the glory of the divine presence that filled the tabernacle (and later the temple) has now come to us in Jesus, then he is the place where we now seek God's presence. Accordingly, we will see John presenting Jesus as the fulfillment of Judaism...But this replacement comes through fulfillment not rejection. Replacement does not mean there is no longer any role for the Old Testament, but it does mean any attempt to know God that is not centered in Jesus is defective, since in him is the fullness...the revelation of God in Jesus is not contradictory to Judaism, but rather the very thing for which Judaism has been preparing."

${ }^{190}$ Dennis, Gathering, 176.

${ }^{191}$ Keener, John, 227. Dennis, Gathering, 351, states, "John did not think in a category such as 'supersessionism' or 'replacement theology'; rather, he believed that his community was the true or genuine Israel. Thus, for John, those who have believed in the Messiah share a fundamental continuity with faithful Israelites in the past." (italics his)
} 


\section{Chapter 3}

\section{The role of Passover in John}

\section{A. Introduction}

The first feast I will examine is the feast of Passover. Passover has the distinction of occurring three times in the Gospel including both the first and last feast mentioned in the narrative. The symbolism of this feast has also contributed more to the Gospel than either Tabernacles or Dedication. It is, therefore, appropriate that it should be treated first. I will argue that the essential element of the Passover tradition which John seizes upon and appropriates in his portrayal of Jesus is the necessity of eating the pascal lamb in order to participate in the covenant community of the restored people of God. Typically scholars give greatest emphasis to the death of Jesus as the Passover sacrifice when considering the use of Passover tradition in the Fourth Gospel. I do not deny the author has cast Jesus as the pascal victim sacrificed on the cross at the same time as the lambs were being slaughtered in the Temple. Notwithstanding this, however, I believe undue emphasis has been accorded this facet of John's use of the Passover tradition. The significance of the sacrifice of Jesus as pascal victim lies, as in contemporary Jewish tradition, not in any atoning value intrinsic to the sacrifice itself but rather in its function as provision for the all-important pascal meal. This becomes clearest in the central Passover context of the three in the Fourth Gospel (John 6) where the author has interwoven Passover tradition with the hope of new exodus redemption, a hope which ran high during Passover season. Ultimately, John portrays Jesus as the pascal lamb who must be eaten by all who would participate in the restoration of the community of the people of God effected by his death. Once more, then, the author most certainly portrays the sacrifice of Jesus in pascal terms, but the point of greatest emphasis is not the sacrifice itself but the pascal meal which centers on the eating of the lamb.

After briefly outlining the evidence for heightened expectations of national deliverance during Passover season, I will analyze the use of Passover tradition in John and its interaction with the Isaianic new exodus tradition.

\section{B. Nationalistic expectations associated with Passover season}

Nationalistic sentiment was present throughout the year, yet it was naturally heightened during the festivals when tens of thousands of Jews made the pilgrimage to Jerusalem to celebrate past saving 
actions of God and to pray for and anticipate future saving acts. ${ }^{192}$ Among annual festivals Passover was probably the largest and most important and may have been the occasion of greatest collective resentment to foreign rule and hope for its overthrow. ${ }^{193}$ This is hardly surprising, of course, since the very heart of the festival is the memory of God's great liberation of the people from foreign oppression, a memory which undoubtedly carried tremendous emotional freight. ${ }^{194}$ It is also likely that the several revolts and disturbances associated with various Passover celebrations, beginning especially with the events following Herod's death, reinforced and heightened this nationalistic spirit and concomitant hope for deliverance at subsequent Passover festivals.

The reports in Josephus of the riots surrounding Passover festivals in the decades before and after Christ comprise the most illuminating body of evidence for the popular association of Passover with hope for national restoration. ${ }^{195}$ The first of these followed the death of Herod when a large crowd gathered in the temple during Passover to mourn the slaying of the men responsible for pulling down Herod's golden eagle. ${ }^{196}$ Before running its course, 3,000 pilgrims lay slain by Archelaus' troops. ${ }^{197}$ The evidence of Josephus combines with the fact of the riot itself to point to the strong likelihood of this Passover being the occasion of a ground swell of anti-Roman sentiment and hope for liberation from the economic, social and religious oppression experienced under Herod. ${ }^{198}$ Another riot reported by

\footnotetext{
192 Tacit evidence of this comes from Cumanus' practice of stationing guards in the temple during Passover to prevent any outbreak of revolt; "and this was no more than the former procurators did at such festivals" (Ant. 20.106-107). See further N.T. Wright, New Testament and the People of God (London: SPCK, 1992), 273-277. ${ }^{193}$ Josephus characterizes Passover sacrificing in remarkably enthusiastic terms and specifies that more animals were sacrificed at this festival than at any other (Ant. 17.213). See on this Frederico M. Colautti, Passover in the Works of Josephus (Leiden: Brill, 2002), 101. Of one Passover Josephus estimates the crowds of pilgrims numbered around 3 million (War 2.280). This is utterly untenable, however, given the space constraints of the city at the time (indeed, this is three times the population of Rome at this time!). More likely the festival swelled the population of Jerusalem to between 50,000-80,000. For discussion, see, e.g., Steve Mason, Judaean War 2: Translation and Commentary (Flavius Josephus : Translation and Commentary; Leiden: Brill, 2008), 228 n. 1796.

${ }^{194}$ Cf., e.g., Richard A. Horsley, Jesus and the Spiral of Violence: Popular Jewish Resistance in Roman Palestine (Minneapolis: Fortress, 1993), 34-35. Perhaps also contributing to the large attendance was the mild weather of the early spring. Not only would this have made the pilgrimage less forbidding but it would likely have been more attractive to those looking to incite insurrection. For if one wanted to begin an insurrection spring, rather than late autumn, would be the most salutary season to begin a potentially protracted armed struggle.

${ }^{195}$ See E.P. Sanders, Jesus and Judaism (London: SCM, 1985), 138, and Mason, Judaean War, 11-12. Josephus reports revolts at Passovers in 4 B.C.E. (Ant. 17.206-218; War 2.1-13), 44 C.E. (Ant. 20.105-112; War 2.224-227) and 66 C.E. (War 2.280-284).

${ }^{196}$ For these events generally, see Ant. 17.146-342; War 1.647-2.111. Colautti, Passover, 192-195, provides a helpful discussion of the events and their connection with Passover.

${ }_{197}$ According to Josephus, War 2.13.

${ }^{198}$ See esp. War 2.4 and Mason, Judaean War, 7-8, for a balanced discussion of the economic (heavy taxes and duties) and social factors (release of those imprisoned by Herod) at play. Colautti, Passover, 194-195, argues that though the events reported by Josephus clearly took place during Passover and in the period between Passover and Pentecost, Josephus has suppressed any clear ideological linkage between the festivals and the disturbances in order "to let the reader think that Passover and Pentecost have only a marginal significance in the unfolding of this
} 
Josephus witnessed the indecent gesture of a soldier stationed in the temple during Passover (44 C.E.) triggered so great a riot that perhaps as many as 20,000 Jews died before it ended. ${ }^{199}$ Here again Josephus indicates (perhaps unwittingly; see below) that pent up frustration against Roman rule, and not simply the soldier's offense, caused the severe response of the Jews and also explains the quickness with which they turned against Cumanus himself. ${ }^{200}$ In all likelihood, this event influenced popular thought at future Passover celebrations. The slaughter of so many worshippers coupled with the canceling of the sacrifices (which amounted to cutting short the entire festival) could hardly have failed to deepen popular association of the feast with Roman oppression and injustice and, by extension, with hope for deliverance.

In addition to recording the riots that took place during Passover festivals Josephus also highlights the Passover setting of several key events surrounding the war with Rome, such as the date of both the outbreak and conclusion of the war (respectively, War 2.280-308 and War 7.401) as well as a series of ominous events portending the Temple's destruction (War 6.290). ${ }^{201}$ On a careful reading, "there seems a good deal of literary manipulation in all this...It seems that he has highlighted Passover in both the structure and substance of his narrative for thematic and symbolic reasons". ${ }^{202}$ In fact, Josephus may have highlighted these Passovers at the outset and the definitive end of the war for thematic purpose, in order to cast in the most bitterly ironic terms the failure of those Jews he regarded as responsible for beginning the unwinnable conflict.

Furthermore, it is likely that there were other instances of unrest during Passovers in the $1^{\text {st }}$ century C.E.. Colautti has argued extensively that Josephus consistently sought to separate the celebration of Passover from the revolts which not infrequently accompanied it in order to suppress any notion of widespread anti-Roman sentiment on the part of the populace at large or inherent in the Passover festival itself. ${ }^{203}$ Josephus implies that in the absence of corrupt Roman governors and lawless

history." He deprives the actors of any "religious inspiration" in order to "disengage Passover of any anti-Roman sentiment." On this, see further below.

${ }^{199}$ The figure is given in Ant. 20.112. War 2.227 reports 10,000. See the cautionary remarks of Mason, Judaean War, 187 n.1419, regarding Josephus' use of population and casualty estimates.

${ }^{200}$ Mason, Judaean War, 186 n. 1412. Cf. Jos. Ant. 20.108 and note the editorial aside by Josephus that the governor was in the habit of maintaining a contingent of troops in Jerusalem during the festival.

${ }^{201} \mathrm{He}$ also pauses to note (with likely embellishment) the celebration of Passover at the height of the war in 70 C.E. which led to the imprisonment of the crowds "for the final catastrophe" (War 5.98-104; 6.428; Mason, Judaean War, 11 n. 67).

${ }^{202}$ Mason, Judaean War, 12 n. 67. For more elaborate development of this line of thought, see Colautti, Passover, 114-119.

${ }^{203}$ For example, Colautti, Passover, 196, suggests Josephus has omitted reference to a Passover setting for the Judas-Saddock rebellion during the visit and census of Quirinius (Ant. 18:1-28). He points to the custom of Governors to visit after winter (cf. War 2.244, 280; Ant. 18.122-123; 20.133) as well as the mention of Florus (Ant. 
Jewish rebels, the Passover celebration is perfectly consistent with peaceful submission to Roman rule.

Colautti concludes,

...when Passover will turn into bloodshed, FJ will incriminate particular persons or circumstances, totally unrelated to the true significance of the feast. In the same line, he will sometimes alter the meaning of a political reaction to make it a religious one and vice-versa. In this way, FJ depicts a somewhat distorted image of the real events, by attempting to free Passover of any political implication that it almost certainly had.

He summarizes the discussion:

...what seems to be an easy conjecture, i.e., that the feast of liberation from Egypt would have been an inspiring motive for those that were striving to definitely expel the foreign oppressors, does not appear to be true in FJ's account. This is not because it is false, but due instead to FJ's attempt to let his reader understand this. ${ }^{204}$

Thus, despite Josephus' efforts to remove from Passover any association of national hope for liberation from Roman oppression, considerable circumstantial evidence suggests that Passover was indeed the occasion for much anti-Roman sentiment. In fact, the picture which emerges from Colautti's careful analysis is of a festival likely characterized at least as much by the expectation of a future (even immanent) deliverance by God from foreign rule as by the celebration of God's past deliverance from Egypt. $^{205}$

18.25) who was associated with the initial revolt of the Jewish War at Passover. The Gospels may furnish evidence of another insurrection at the time of the Passover when Jesus was crucified (cf. Mark 15:7).

${ }^{204}$ Colautti, Passover, 217. He strengthens the likelihood of this inference by appeal to the sign-prophets associated with the War in Josephus. Following a detailed analysis, he concludes that the Jewish insurrectionists whom Josephus so hates and aims to dissociate from Passover nevertheless "acted in connection with Passover". See Passover, 207-217.

${ }^{205}$ Numismatic evidence may corroborate the contention that Passover was a time of heightened expectation of national liberation from Rome. C. Roth has argued plausibly that a series of coins bearing a jeweled chalice and dating to the time of the first Jewish war with Rome indicate the popular correlation of Passover and messianic restoration themes in the first century C.E. (the cup representing the "cup of salvation" associated with redemption and the Passover Hallel Ps 116). See C. Roth, "Messianic Symbols in Palestinian Archaeology," PEQ 87 (1955) 160. Also note the discussion of Andrew C. Brunson, Psalm 118 in the Gospel of John: An Intertextual Study on the New Exodus Pattern in the Theology of John (Wissenschaftliche Untersuchungen Zum Neuen Testament; Tübingen: Mohr Siebeck, 2003), 71-72, who surveys the rabbinic evidence sometimes thought to support this view and concludes that "the cup of salvation of Ps 116 probably had eschatological-messianic associations in Second Temple 
Stepping back and pulling together the results of this survey it is possible to conclude that popular thought in the time of Jesus maintained a strong association between Passover and the hope of national deliverance. Thus, while aiming to avoid the overstatement of some scholars, I conclude that throughout the period of the second Temple, "Passover, the paradigmatic symbol of Biblical deliverance, was looked at as the pattern for a new exodus or liberation." ${ }^{206}$

\section{Passover in John: Jesus as pascal victim}

I come, now, to an examination of John's use of the Passover tradition in his presentation of Jesus. I will argue that John has chiefly drawn upon and emphasized one particular facet of Passover tradition: the constitutive importance of eating the pascal meal for community membership. This facet of Passover tradition ultimately serves John's larger theological program whereby he interprets the death and resurrection of Jesus as the realization of the new exodus hope of Isaiah. John takes full advantage of contemporary associations of Passover with hopes for national deliverance by merging this tradition with the restoration tradition of Isaiah.

The uniqueness of my contribution, however, lies in the relocation of John's emphasis within the Passover tradition to the pascal meal. This dimension of the tradition has too often been overlooked as scholars give greatest emphasis to Jesus' death as pascal sacrifice. ${ }^{207}$ The author clearly represents Jesus

Judaism. Its special link with Passover would only enhance the inherent themes of liberation already present in both psalm and feast."

${ }^{206}$ Brunson, Psalm 118, 81. Brunson himself is careful to distance his conclusions from the excess of Jeremias who paints a manifestly anachronistic picture of second Temple thought, at this point, based chiefly on later Rabbinic sources. Note, for example, the well-known statement of Joachim Jeremias, heavily footnoted with Rabbinic sources, that "the Passover is a looking forward to the coming deliverance of which the deliverance from Egypt is a prototype...The night of Passover is called the 'sign' through which God guarantees the coming of the Messiah. The Passover traditions variously reflect the vitality of this Messianic hope, just as do the revolts against Rome which took place at the Passover" (The Eucharistic Words of Jesus (trans. Norman Perrin from the German 3rd ed., with the author`s revision to July 1964; New Testament Library; London: SCM, 1966), 206-207; italics his). I have argued for the likelihood of a general hope for national deliverance in association with Passover, yet within prerabbinic sources there is little evidence to confirm the association of specifically Messianic expectation with Passover.

${ }^{207}$ An example is Gerald Borchert who, in an extended review of the function of Passover in the narrative cycles in John, focuses exclusively on the sacrifice of Jesus as pascal lamb. Even his treatment of John 6 refers only to "the immanent self-sacrifice of Jesus", ignoring entirely the theme of eating that dominates the chapter. See "The Passover and the Narrative Cycles in John," in Perspectives on John: Method and Interpretation in the Fourth Gospel (ed. Robert B. Sloan and Mikeal C. Parsons; Lewiston, Maine: Edwin Mellen Press, 1993), 303-316, esp. 309-310. The same pattern of thought is evident throughout the lengthy article by Stanley Porter, "Can traditional Exegesis Enlighten Literary Analysis of the Fourth Gospel? An Examination of the Old Testament Fulfillment Motif and the Passover Theme," in The Gospels and the Scriptures of Israel (Journal for the Study of the New Testament Supplement; eds. Craig A. Evans and W. Richard Stegner; Sheffield: Sheffield Academic Press, 1994) 396-428, esp. 413-414 on John 6. 
as the pascal victim sacrificed on the cross at the same time as the lambs were being slaughtered in the Temple. Yet this facet of John's use of the tradition has been unduly emphasized above the pascal meal which, I will try to show, in fact stands at the heart of John's use of the Passover tradition. The significance of the sacrifice of Jesus as pascal victim lies not predominantly in any value intrinsic to the sacrifice itself, but rather in its function as provision for the pascal meal, the eating of which is requisite for participation in the covenant community that is restored through the death of Jesus.

The crucial exposition of the meaning of the Passover motif in John is given in the central Passover of the three which punctuate the public ministry of Jesus (John $2: 12 ; 6: 4 ; 11: 55$ ). ${ }^{208}$ It is here that the author clarifies the essential import of the Passover symbolism, namely the necessity and benefit of eating the pascal meal. Before turning to a detailed analysis of this chapter, however, I will rehearse the well-known evidence outside John 6 that the author portrays the death of Jesus in terms of the pascal victim. In the process I will note the important conjunction of the Suffering Servant tradition with the Passover tradition.

In John 1:29, John the Baptist declares, "Behold, the Lamb of God who takes away the sin of the world." While many interpretations of the "Lamb of God" have been proposed, ${ }^{209}$ an apparent consensus today discerns dual references to the Paschal lamb and the "lamb led to the slaughter" of Isa 53:7. ${ }^{210}$ Most recently, Nielsen has utilized "conceptual blending theory" to argue that the declaration at John 1:29 integrates the entire semantic value of each background (Passover lamb and Isa 53) and

\footnotetext{
${ }^{208}$ In his assessment of Passover, Kerr, Temple, 208-226, also treats John 6 as determinative for the significance of the festival in John. Depending on how one numbers the signs of the Fourth Gospel, the feeding miracle can also be understood as the fourth (central) sign of the seven. Cf., e.g., Joseph A. Grassi, "Eating Jesus' Flesh and Drinking His Blood: The Centrality and Meaning of John 6:51-58," BTB 17 (1987) 25.

${ }^{209}$ The literature in the last hundred years on this question is substantial and more than a dozen different proposals have been set forth. For recent surveys, see Jesper Tang Nielson, "The Lamb of God: The Cognitive Structure of a Johannine Metaphor," in Imagery in the Gospel of John (Wissenschaftliche Untersuchungen Zum Neuen Testament 200; ed. Jorg Frey; Tübingen: Mohr, 1996) 225-227, and Christopher W. Skinner, "Another Look at the Lamb of God," BibSac 161 (2004) 90-102.

${ }^{210}$ Westcott, John, 1.39; C. K. Barrett, "The Lamb of God," NTS 1 (1954-1955) 217; Brown, John, 61-63; Lindars, John, 109; Bruce H. Grigsby, "The Cross as an Expiatory Sacrifice in the Fourth Gospel," JSNT 15 (1982) 54; G.L. Carey, "The Lamb of God and Atonement Theories," TynB 32 (1981) 105-107, 119; D. Brent Sandy, "John the Baptist's 'Lamb of God' Affirmation in its Canonical and Apocalyptic Milieu," JETS 34 (1991) 457-458 (who, though conceding the Evangelist's use of Passover and Isa 53, here, prefers the apocalyptic lamb tradition as the original reference of the Baptist); Porter, "Passover", 407-411; Kerr, Temple, 211; Keener, John, 453-454; Williams, "Testimony", 111; Davies, Rhetoric, 234; Lincoln, John, 113; J. Terence Forestell, The Word of the Cross: Salvation as Revelation in the Fourth Gospel (Analecta Biblica; Rome: Biblical Institute Press, 1974), $157-$ 166.
} 
then evokes the image at various points throughout the Gospel in order to "activate" distinct elements from each to show how he is the Lamb of God. ${ }^{211}$

Throughout the passion narrative the author aligns Jesus at once with the Suffering Servant and the Passover lamb. ${ }^{212}$ Allusions to the former include the "mockery motif" 213 and the threefold declaration of his innocence. ${ }^{214}$ There may also be echoes from the fourth Servant song of Isaiah surrounding his being "lead away", "taken away" and "handed over" to death. ${ }^{215}$ The alignment with the pascal victims is achieved by a number of literary features in the text. For example, the three express references to Passover in John 18-19 frame the central scene before Pilate, occuring roughly at the beginning (18:28), middle (18:39) and end (19:14) of the account of his trial and condemnation to death. Also evocative of the pascal victims is the careful coordination of the execution of Jesus with the slaughter of the lambs in the Temple. ${ }^{216}$ At the climax of the trial scene, before Pilate pronounces his

\footnotetext{
${ }^{211}$ Nielson, "Lamb". Nielsen's work answers two common objections to this reading of John 1:29: that the Passover

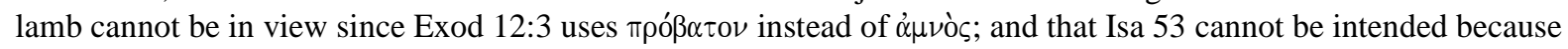
the expression "Lamb of God" is far removed linguistically from anything in the Fourth Servant Song (so, e.g., Morris, John, 146; Carson, John, 149; Skinner, "Lamb", 100). Nielsen shows that it is part of the very nature and purpose of the blending of such images to create something quite new. In the case of the integration of both Passover and Isa 53 in the image of John 1:29, Jesus "is neither the Suffering Servant nor the Passover lamb, but the Lamb of God", the meaning of which is then elucidated in terms of both these backgrounds over the course of the Gospel narrative. See esp. "Lamb", 217-225, 240, 255-256. Porter, "Passover", 409-411, approximates the same view.

${ }^{212}$ Again, Nielson, "Lamb", 253, 255, argues for the purposeful "blending" of both backgrounds in the passion narrative with a view toward the fuller characterization of Jesus' death.

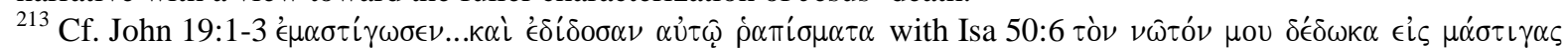

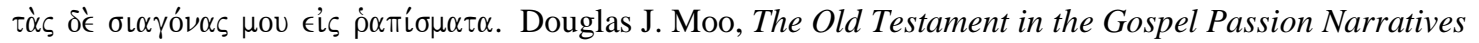
(Sheffield, England: Almond Press, 1983), 139, 143.

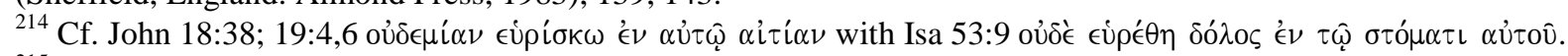

${ }^{215}$ Four times Jesus is lead $\left({ }^{\prime \prime} \gamma \omega\right)$ from one place to another in connection with his death: by Judas and his band to Annas (18:13); from Caiaphas to Pilate (18:28); from Pilate to the Jews (19:4,13). This motif (probably begun already in the aborted attempt to bring Jesus for trial in John 7:45 as well as the bringing of the blind man for interrogation before the same assembly in 9:13) likely echoes the description of the Servant in Isa 53:7-8: "like a lamb that is led $(\eta \chi \chi \theta \eta)$ to the slaughter....because of the iniquities of my people he was led (" $\chi \theta \eta)$ to death." Next, at

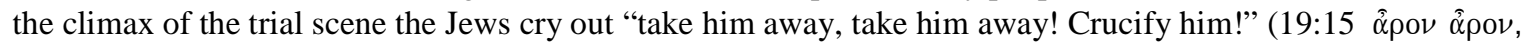

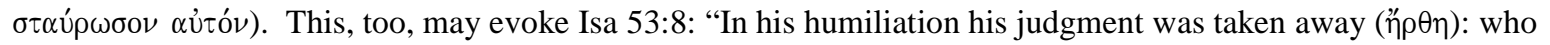
shall declare his generation? For his life is taken away $(\alpha$ ” $\rho \in \tau \alpha \iota)$ from the earth." Finally, the language of "handing over" $(\pi \alpha \rho \alpha \delta\llcorner\delta \omega \mu \iota)$ forms an important motif in both John's passion narrative (the term occurs 7 times outside the passion and 8 times within [7 times with Jesus as object; 1 time \{the eighth \} with Jesus as subject]; cf. 6:64, 71; $12: 4 ; 13: 2,11,21 ; 18: 2,5,30,35,36 ; 19: 11,16,30 ; 21: 20$ ) as well as the fourth Servant song (Isa 53:6,12[2x]; for discussion, see Eugene Robert Ekblad, Isaiah`s Servant Poems according to the Septuagint: An Exegetical and Theological Study (Contributions to Biblical Exegesis and Theology; Leuven: Peeters, 1999), 225-226, 266). An allusion here, too, seems very likely.

${ }^{216}$ Westcott, John, 2.305; Hoskyns, John, 525; Barrett, John, 545; Lindars, John, 571; Grigsby, “Cross”, 54-55; Yee, Feasts, 68; Porter, "Passover", 418-419; Coloe, Dwells, 192; Keener, John, 690; Kerr, Temple, 208; Donald Senior, The Passion of Jesus in the Gospel of John, (Collegeville, Minn: Liturgical Press, 1991), 96. Harmonizing views, represented by, e.g., Carson, 589-590, and B.D. Smith, "The Chronology of the Last Supper," WTJ 53 (1991) 29-45, are rebutted by R.T. France, "Chronological Aspects of 'Gospel Harmony'," Vox Evangelica 16 (1986): 3359 , who highlights the unnatural readings which result from such harmonizations. Similarly, in his literary-critical
} 


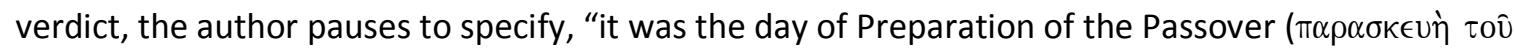
$\pi \alpha \dot{\sigma} \sigma \alpha)$; it was about the sixth hour" (19:14). Scholars also commonly discern allusions to the pascal victims in the mention, uniquely among the Gospels, of the hyssop branch $(19: 29)^{217}$ as well as the statement that his bones remained unbroken in express fulfillment of the Paschal requirement of Exod $12: 46(19: 33,36){ }^{218}$ One might also highlight the removal of the body from the cross before morning (19:31, 38; cf. Exod 12:10) ${ }^{219}$ and thrice repeated declaration of his innocence by Pilate $(18: 38 ; 19: 4,6)$. While the latter might correspond most immediately to the innocence of the Suffering Servant (Isa 53:9), it may also correspond figuratively to the requirement that the paschal lamb be without spot (Exod 12:5), though this is uncertain. Jesus, the author may hint, is a lamb "without blemish or defect" ${ }^{220}$

Without question John casts the crucifixion of Jesus in terms of both the Suffering Servant and the sacrifice of the pascal lamb. ${ }^{221}$ What, however, is the symbolic value of the latter association? Considerable debate has focused on whether or not the sacrifice of the pascal lambs in the Temple could properly be understood as effecting substitutionary atonement for $\sin .{ }^{222}$ A perennial obstacle to

study of John 18-19, Mark W.G. Stibbe comments on the timing of Jesus' death in 19:14 in connection with the use of Passover throughout the Gospel: "I suggest that narrative chronology is inseparable from narrative Christology, that the importance of John's story time derives from the fact that Jesus is implicitly depicted as the true pascal lamb" (John as Storyteller: Narrative Criticism and the Fourth Gospel (Cambridge: Cambridge University Press, 1992), 115). Elsewhere, he argues that the shaping of John's passion account around the immanent slaughter of the pascal lambs ("what I call his Passover plot") represents his distinctive contribution to the passion tradition (Storyteller, 191). For more detailed assessment of the chronology of John's passion account in relation to that of the Synoptics, see Barrett, John, 48-51, and Raymond E. Brown, The Death of the Messiah: From Gethsemane to the Grave--a Commentary on the Passion Narratives in the Four Gospels (London: Geoffrey Chapman, 1994), 1350-1376.

${ }^{217}$ Grigsby, "Cross", 57, responds well to the reluctance of some, here, (e.g., Bultmann, John, 674 n.2) by noting the characteristically elusive nature of Johannine allusions as well as the probability that John has altered the more natural report of Markan tradition (Mark 15:36 refers to a "reed" [ $\kappa \alpha \lambda \alpha \dot{\alpha} \mu \omega]$ ], a stiffer, more suitable plant for lifting a liquid-filled sponge). See also Yee, Feasts, 68; Barrett, John, 553; Davies, Rhetoric, 24, 234, 305, 355; Stibbe, Storyteller, 191; Porter, "Passover", 420; Coloe, Dwells, 193; Moloney, Glory, 146; and esp. F.G. Beetham and P.A. Beetham, "A Note on John 19:29," JTS 44 (1993): 163-169.

${ }^{218}$ Cf. Grassi, "Eating", 28; Grigsby, "Cross", 58-59; Yee, Feasts, 68; Stibbe, Storyteller, 191; Coloe, Dwells, $192-$ 193; Porter, "Passover", 420; Moloney, Glory, 147; Keener, John, 1155; Kerr, Temple, 209; Brown, John, 952-953, who observes the pascal motif here "forms an excellent inclusion with the Baptist's testimony" at 1:29 (the same observation is made by J. Zumstein, "L'interprétation johannique de la mort du Christ Pages," in The Four Gospels: Festschrift Frans Neirynck, III.IV (eds. F. Van Segbroeck, C.M. Tuckett, G. Van Belle and J. Verheyden; Leuven: Leuven University/Peeters, 1992) 2119-2138, 2130). For the likelihood that Ps 34:21 is the text cited, here, see M.J.J. Menken, "The Textual Form and the Meaning of the Quotation from Zechariah 12:10 in John 19:37," CBQ 55 (1993): 494-511, and Brown, Death, 1185-1186, each of whom conclude that the author invokes both passages. ${ }^{219}$ Davies, Rhetoric, 234.

${ }^{220}$ Cf. Lincoln, John, v113.

${ }^{221}$ For the sacrificial nature of the pascal victim in $1^{\text {st }}$-century Judaism, see Keener, 454; and cf. Pancaro, Law, 348.

${ }^{222}$ Though most recognize the difficulty in regarding the pascal sacrifice as atoning, some scholars nevertheless view the pascal sacrifice as bearing redemptive value of some kind. E.g., Brown, John, 62; Schnackenburg, John, 1.300; Carey, "Lamb", 118-119; Kerr, Temple, 211, following Pancaro, Law, 348; Skinner, "Lamb", 97-98, 
interpretations which answer in the affirmative is the lack of basis for this thought in the Old Testament and contemporary Jewish sources which treat Passover. ${ }^{223}$ Insisting upon the atoning nature of the pascal sacrifice appears to be the result of failing to give adequate attention to the Isa 53 background. The concept of substitutionary atonement is more easily traced to Isa 53 than contemporary (or Old Testament) Passover tradition. It seems best to concede that the Passover tradition does not contribute to the question of the atoning value of Jesus' death. ${ }^{224}$ The question remains, then, what symbolic value John attached to Jesus' death as pascal victim.

In what follows I will argue that John utilizes the tradition surrounding the necessity of eating the pascal lamb for community membership in order to indicate that those who would participate in the new exodus deliverance Jesus brings must eat the pascal meal he provides by coming to him as the crucified Son of God in believing, abiding fellowship. Here, and not with atonement theology, lies the meaning of the alignment of Jesus with the sacrificial lambs of Passover.

following Morris, John, 145. Coloe, Dwells, 194-196, notes the non-expiatory nature of the pascal sacrifice but nevertheless puts all emphasis in John's pascal symbolism on the death of Jesus. For her, it is not atonement for sin but liberation from the power of sin which is "signified" by Jesus' death. Others regard John 1:29 as evincing an Isaac typology rooted in an early Jewish association of the Akedah with Passover and atonement for national sin. Cf. Westcott, John, 1.39; GezaVermes, Scripture and Tradition in Judaism: Haggadic Studies (Studia Post-Biblica; Leiden: Brill, 1961), 223-225 (he treats the Jewish use of Gen 22 and its supposed influence on the New Testament on 193-227); Glasson, Moses, 98-100; Grigsby, "Cross", 59-61; R.J. Daly, "The Soteriological Significance of the Sacrifice of Isaac," CBQ 39 (1977): 45-75; J. Edwin Wood, "Isaac Typology in the New Testament," NTS 14 (19671968): 583-589; Fréderic Manns, "Note on the Sacrifice of Isaac in the Fourth Gospel," in The Sacrifice of Isaac in the Three Monotheistic Religions (ed. Frederic Manns; Studium Biblicum Franciscanum Analecta, 41; Jerusalem: Franciscan, 1995) 99-100; and esp. Roger Le Déaut, La Nuit Pascale: essai sur la signification de la Pâque juive à partir du Targum d'Exode XII 42 (Analecta biblica; Rome: Institut biblique pontifical, 1963) 133-212; F.-M. Braun, Jean Le Thèologien: Sa Thèologie - Le Mystère de Jèsus-Christ - Vol. III (Études Bibliques; Paris, 1966), 161-164. Whether or not John 1:29 alludes to the Akedah, it is highly doubtful that the sacrifice of Isaac was regarded as sinbearing during the second Temple period. The critique of this view has been forcefully made by P.R. Davies and B.D. Chilton, "The Aqedah: A Revised Tradition History," CBQ 40 (1978): 514-546. For a more recent survey of the debate and examination of the Jewish sources, see Joseph Fitzmyer, "The sacrifice of Isaac in Qumran literature," Bib 83 (2002): 211-229. He concludes that the sacrifice of Isaac began to capture Jewish imagination in early works such as Jub. 17:15-18:16 and 4Q225 2.i-ii ("Pseudo-Jubilees"), underwent continued development (L.A.B. 18:5 and 32:3), and only finally achieved full-blown expiatory significance in later Targumic interpretations. ${ }^{223}$ For a helpful survey of the Jewish evidence, see Nielsen, "Lamb", 233-239. Brown, John, 62, and Pancaro, Law, 348, for example, (followed by Kerr, Temple, 211), argue that the sacrifice of the pascal victim could be associated with redemption. This may be true, but as Barrett, "Lamb", 217, points out, although the New Testament authors utilize Passover imagery in Eucharistic discussions of Jesus' death (e.g., 1 Cor 5:7-8), they never do so "in those passages which most plainly speak of the death of Christ as expiation" (cf. Rom 3:25; 1 Cor 15:3; 1 John 2:2; 3:5). ${ }^{224}$ It bears emphasizing, here, that this conclusion by no means undermines the contention that the Fourth Gospel interprets the death of Jesus in expiatory terms. See, esp., John Dennis, "Jesus' Death in John's Gospel: A Survey of Research from Bultmann to the Present with Special Reference to the Johannine Hyper-Texts," CBR 4 (2006): 331363, who documents the sea change in scholarly (particularly German) treatment of the subject in recent decades. I am in full agreement with, e.g., D. Moody Smith, The Theology of the Gospel of John (New Testament Theology; Cambridge: Cambridge University Press, 1995), 115-121, who argues that John presupposes the idea of vicarious sacrifice found in Mark, Paul, Hebrews, 1 John and Revelation, but that John, nevertheless, gives greater attention to the revelatory significance of Jesus' death. 


\section{Significance of Jesus' pascal sacrifice}

\section{D.i. Thematic contours of John 6}

In order to draw out this thesis I will examine the central Passover context of the Gospel. Throughout John 6 two emphases dominate the author's message. The first of these is that Jesus effects the national restoration from exile. The opening miracle narrative, expressly set against Passover, represents Jesus as the source for the pascal meal. In addition, the highly symbolic gathering of leftover fragments into twelve baskets symbolizes the restoration of the nation. The discourse section (6:26-58) elaborates and brings into relation these two ideas by portraying the national restoration in terms of the new exodus of Isaiah and declaring climactically in verse 51 that Jesus will bring about this redemption by giving his own flesh over to death. The likely allusion in this verse to the Suffering Servant indicates that it is the efficacy of his death which accomplishes this deliverance. A second allusion in this verse identifies Jesus with the pascal sacrifice and leads to my final section on the import of the pascal meal.

The second emphasis of John 6 is the necessity of entering into believing, abiding fellowship with Jesus himself for participation in this restored community. Beginning with the feeding miracle and continuing throughout the discourse, the metaphor of eating that which Jesus provides dominates the narrative. At a number of points it becomes clear that the consumption of the pascal meal functions as a metaphor for believing, abiding communion with Jesus. This communion forms the means of participation in the new exodus life Jesus procures through his death. The fundamental question I seek to answer is why the author has chosen to appropriate the metaphor of the pascal meal in this way. I will adduce evidence to suggest that John's use of Passover draws on an important facet of Jewish tradition, namely, the association of the eating of the pascal meal with participation in the covenant community.

In order to adequately establish my interpretation I will treat these two emphases successively. First, I will consider the themes of Passover and the Isaianic new exodus across John 6 to show that Jesus effects the new exodus deliverance by means of his death as pascal victim and, perhaps, Suffering Servant. After this, I will consider the symbolic associations surrounding the meal in the Jewish background. From this I hope to show that, ultimately, the import of the Passover festival for John lies in the meal as enactment of community membership. If the death of Jesus effects the restoration of the nation, participation in this renewed covenant community is achieved through partaking of the pascal meal supplied in the flesh of Jesus, the true pascal lamb. 


\section{D.ii. Passover theme in John 6}

\section{D.ii.1. Opening Miracle}

John 6 repeatedly, and in various ways, characterizes the death of Jesus in terms of both the Passover sacrifice and the Isaianic new exodus. I will treat these twin themes separately before stepping back to consider how precisely they are interrelated. Though mentioned expressly only at 6:4, the immanent Passover festival supplies a pivotal component to the symbolic background for both the feeding narrative and for the discourse that follows. Though somewhat overstating the matter, the oftquoted words of Hoskyns point in the right direction: "the movement from the miracle to the discourse, from Moses to Jesus...and, above all, from bread to flesh, is almost unintelligible unless the reference in v. 4 to the Passover picks up i.29, 36 and anticipates xix.36...and governs the whole narrative."225

To begin with, the narrative flow in verses 4-5 rather naturally connects the meal Jesus provides with the Passover festival: verse 4 mentions that "Passover, the feast of the Jews, was at hand"; verse 5 follows directly with "then as Jesus lifted up his eyes and saw that a great crowd was coming to him", at which point he asked Philip how they might feed the people. ${ }^{226}$ Moreover, Jesus and the people ascend a mountain at the same time myriad pilgrims are ascending the Temple mount for the festival in Jerusalem. ${ }^{227}$ The mention of "much grass" implies Passover season. ${ }^{228}$ The people "recline" ('ُ $\nu \alpha \pi \epsilon \sigma \in \hat{\imath} \nu$ / $\dot{\alpha} \nu \alpha \kappa \in \iota \mu \epsilon \operatorname{co\iota \varsigma })$ in a manner to be expected at the Passover meal in Jerusalem. ${ }^{229}$ Finally, though not

\footnotetext{
${ }^{225}$ Hoskyns, John, 281. He notes further (289), verse 4 "was not introduced in order to assist the readers of the gospel to make out a chronology of the life of Jesus, but to provide them with the proper background of His acts and words." More specifically, Keener, John, 665, concludes, "the most important function of John's mention of Passover is thus that it sets the rest of the chapter in the context of the pascal lamb". Cf. also Westcott, John, 1.211; Marsh, John, 283; Bruce, John, 143; Meeks, Prophet-King, 92; Brown, John, 245; Lincoln, John, 211;

Köstenberger, John, 200; L. Witkamp, “Johannine Features in John 6:1-21,” JSNT 40 (1990) 48.

${ }^{226}$ The term '́ $\gamma \gamma$ ù $\varsigma$ is used with reference to each of the three Passovers in John's Gospel $(2: 13 ; 6: 4 ; 11: 55)$ as well as the feast of Tabernacles (7:2-3). In each case the term denotes sufficient temporal proximity that those who plan on attending begin the journey to Jerusalem. It seems a reasonable inference that the people still in Galilee when the festival is "at hand" do not plan to attend.

${ }^{227}$ Jane S. Webster, Ingesting Jesus: Eating and Drinking in the Gospel of John, (Society of Biblical Literature Academia Biblica, No.6. Atlanta, Georgia: Society of Biblical Literature, 2003), 67.

${ }^{228}$ Noted in Westcott, John, 1.214; Schnackenburg, John, 2.14; Kerr, Temple, 223; Lincoln, John, 212; Carson, John, 270; Beasley-Murray, John, 84; Witkamp, "Features", 58 n.3.

${ }^{229}$ Cf. m. Pes. 10.1. So, cautiously, Keener, John, 666. Reclining, of course, was not distinctive to Passover, nor is there unambiguous evidence of legislation mandating the practice in connection with Passover during this period. On the requirement of reclining for the pascal meal in $m$. Pes 10.1, David Brewer concludes that "although it was undoubtedly the custom before $70 \mathrm{CE}$ to recline at Passover, this passage does not provide any evidence that a ruling about it originated before 70 CE" (Feasts and Sabbaths: Passover and Atonement, Traditions of the Rabbis from the Era of the New Testament 2a, (Grand Rapids, Mich: Eerdmans, 2010), 174; cf. 172). Nevertheless, though not required, it was likely customary, not least due to its associations with free persons in Greek culture (from which the custom was borrowed). Cf. Keener, John, 900 n.17, and literature cited.
} 
indicative of Passover specifically, yet several features of the scene cast Jesus in the form of a gracious host at a formal meal. ${ }^{230}$

The conclusion of the opening narrative with the people's desire to make Jesus their king is also suggestive of (or at least consonant with) a Passover theme throughout the account. I argued above that Passover was a time of heightened nationalistic expectation as witnessed to by the occurrence of riots at several festivals. Moreover, the history of Galilee and Judea in the decades between the death of Herod the Great and the war with Rome (4 B.C.E. - 66 C.E.) witnessed the rise of many Moses-type prophets who led crowds of people to various locales with promises of "signs" portending a new exodus/conquest-type deliverance. ${ }^{231}$ Though there are no accounts of such figures arising during a Passover festival, the heightened sense of eschatological fervor could reasonably be expected to have disposed celebrants to recognize a prophet who comes with exodus-type signs as the bringer of national deliverance. $^{232}$

The Passover festival, in other words, "was a rallying point for intense, nationalistic zeal. This goes some way to explaining the fervor that tried to force Jesus to become king" ${ }^{233}$ The response of the crowd is fully consonant with the association of sign-prophets with Passover and the expectation of

\footnotetext{
${ }^{230}$ E.g., the blessing (6:11) and, especially in light of the earlier provision-narrative of 2:1-11, the abundant leftovers signaling a provident host (cf. Keener, John, 667-668). Some of the features listed above have been regarded as allusive of other Old Testament backgrounds. For example, some scholars have detect resonances in John 6:9-13 with $2 \mathrm{Kgs}$ 4:42-44 in which one hundred men are fed from just twenty loaves of bread with some to spare (e.g., Schnackenburg, 2.16; Brown, John, 246; Wengst, Johannesevangelium, 220; Whitacre, John, 145; see further the literature cited in Moloney, Signs, 34, and Keener, John, 667, 668). Others detect echoes of Ps 23:1-2 in the grassy setting, the command to recline, and the abundant provision by Jesus (see esp. Moloney, Signs, 34-35;

Schnackenburg, John, 2.16; Brodie, John, 261). The former suggestion has some merit on both verbal and thematic levels, suggesting "Der Anklang an 2Kön 4 lässt Jesus in biblischer, prophetischer Tradition stehen" (Wengst, Johannesevangelium, 220), or even that "Jesus far surpasses the Old Testament man of God" (Schnackenburg, 2.16). By contrast, however, an allusion to Ps 23 lacks any verbal basis whatever (as Moloney concedes), and the thematic correspondence with Jesus' abundant provision is better explained with reference to Num 11 (see below), and perhaps 2 Kgs 4:42-44.

${ }^{231}$ For helpful summaries of the evidence, see Richard Bauckham, "Messianism According to the Gospel of John," in Challenging Perspectives on the Gospel of John (ed. John Lierman; WUNT 219, Tübingen: Mohr, 2006) 42-49, and John Dennis, "The Presence and Function of Second Exodus-Restoration Imagery in John 6," SNTU 30 (2005) 109-114. Bauckham points out that the absence of reports in Josephus of Moses-type prophets in the years prior to Theudas (45 C.E.) ought not to be regarded as evidence of the absence of such figures ("Messianism", 49). In the first place, Josephus could not draw upon personal memory from this period to supplement a paucity of sources. Nor would minor movements that were quickly suppressed necessarily have been prominent enough to have been reported in Josephus' accounts. Finally, it must be remembered that John the Baptist himself needs to be understood in similar terms to later Moses-type prophets, even if differing in important ways. See Webb, John, ch 10.

${ }^{232}$ See Hylen, John 6, 121-123.

${ }^{233}$ Carson, John, 269, and cf. Webster, Ingesting, 68; Borchert, John, 1.257; Yee, Feasts, 65; Bruce, John, 144, observes "these 5,000 men would have constituted a ready-made guerilla force to anyone willing to become their leader, and verse 15 suggests a leader is just what they were looking for."
} 
eschatological deliverance in the early- to mid-1 $1^{\text {st }}$ century C.E... ${ }^{234}$ The denouement of the feeding narrative, then, confirms the importance of the pascal setting of the scene.

In summary, though the meal Jesus provides is not a formal Passover meal, many features of the narrative invite the reader to view the meal in pascal terms. As Jewish pilgrims make their journey to Jerusalem for the festival, these crowds come to Jesus to receive a symbolic paschal meal. ${ }^{235}$

\section{D.ii.2. Development in discourse section}

The thematic background of Passover exerts a shaping influence on the discourse section of the chapter, as well. ${ }^{236}$ Commentators commonly note the intrinsic linkage between the feeding "sign" and the later discourse. Within the narrative of John 6 the miraculous meal Jesus provided for the people was not an end in itself but a symbolic pointer to the real provision he would make. ${ }^{237}$ This is evident already from the conclusion of the scene when Jesus reacts to the crowd's effort to make him king by fleeing their presence. In this way Jesus signaled that the real import of his "sign" lies elsewhere. ${ }^{238}$ Beginning, then, with the rebuke of verse 26 the "discourse...draws attention away from the feeding miracle itself, interpreting it only as a 'sign', a symbol of the 'real bread'.,"239 The discourse functions to clarify the real nature and goal of Jesus' provision.

Though invoked in this way at the outset of the discourse, Passover recedes from prominence as the focus shifts to the wilderness experience (6:31-51). Nevertheless, the manna theme which runs from 6:31 throughout the discourse likely carries some Passover overtones, though to what extent is difficult to determine with certainty. ${ }^{240}$ In Josh 5:10-12 the manna provision is brought into association with Passover when the manna ceases following the celebration of the first Passover in Canaan. Mekilta de Rabbi Ishmael on Exodus 16:1 explains that the manna first fell precisely one month after the

\footnotetext{
${ }^{234}$ On this connection between the sign-prophets and Passover, see Colautti, Passover, 207-217.

${ }^{235}$ That Jesus provides bread, and not lamb, is no obstacle to this reading. For as we will see subsequently, this bread symbolizes the "flesh" of Jesus body which he would give over to death as the true Passover sacrifice, thereafter to be "eaten" by all who would enter the life he offers.

${ }^{236}$ Again, cf. the quotations above from Hoskyns, John, 281, and Keener, 665. Meeks, Prophet-King, 92, states, "the Evangelist's mention of the season in v.4 justifies attempts to discover allusions in the Johannine discourse to Passover traditions".

${ }^{237}$ Cf. Beasley-Murray, John, 98; Borchert, John, 1.261-262; Lincoln, John, 216, 226. Representative is Dianna Swancutt, "Hungers Assuaged by the Bread from Heaven," in Early Christian Interpretation of the Scriptures of Israel: Investigations and Proposals (eds. Craig A. Evans and James A. Sanders, JSNTSupp 148; Sheffield:

Sheffield Academic Press, 1997) 245, who characterizes the discourse as "a commentary on Jesus' feeding of the five thousand and the crossing of the sea."

${ }^{238}$ So, Witkamp, "Features", 50; Lincoln, John, 216. The express Passover setting leads Moloney, Signs, 38, to regard the gathering of the leftover pieces in 6:12-13 as a prolepsis drawing the reader "further into the narrative" to discover, over against the manna provided in the wilderness, the nature of the bread Jesus gives.

${ }^{239}$ Meeks, Prophet-King, 93 (cf. 91); and see Brown, John, 264.

${ }^{240}$ Brown, John, 245, 265; Moloney, Signs, 46.
} 
departure from Egypt, the fifteenth day of the second month, the date associated with the celebration of the second Passover according to Num 9:9-11. ${ }^{241}$ This source is, of course, quite late and so cannot be considered decisive for a connection between Manna and Passover in John $6 .{ }^{242}$ However, the work of Bertil Gärtner on the Jewish Passover Haggadah (JPH) and John 6 may prove useful at this point. Gärtner argued that the essential structure and content of John 6 has been modeled after the mealquestions-interpretation format of JPH. ${ }^{243}$ Though his major thesis of direct Johannine dependence on JPH has not been accepted by most scholars, much of the evidence he marshals is suggestive of a contemporary association between the manna and Passover traditions. Following a survey of the evidence of John 6, Kerr tentatively proposes, "there could have been some form of JPH in the background that has been worked over and molded into the narrative dialogue of Jesus with the Jews. My conclusion is that there is a general allusion to JPH rather than specific correspondences."244 Thus, while the language of the manna tradition predominates from 6:31-51, the eschatological correlation of the manna and Passover traditions in JPH suggests the latter should not be excluded from the background of 6:31-51 (though it should not be overstated, either). ${ }^{245}$

Beginning with verse 51 and continuing through the conclusion of the discourse Passover returns to the foreground and supplies the essential conceptual matrix for the imagery of eating and drinking. ${ }^{246}$ The convergence in 6:51 of the terms "give", "flesh" and "on behalf of" suggest that a sacrificial death is envisaged here. ${ }^{247}$ Some commentators argue that John 6:51 identifies Jesus with the

\footnotetext{
${ }^{241}$ Cited by Brown, John, 265.

${ }^{242}$ Brown recognizes this and remains uncertain about its importance.

${ }^{243} \mathrm{He}$ argued that the four questions asked in JPH are appropriated in John 6:28, 32, 42, 52. Gärtner was anticipated by David Daube, The New Testament and Rabbinic Judaism (Jordan Lectures in Comparative Religion; London: Athlone Press, 1956), 163-169, and later elaborated upon by Edward J. Kilmarten, "Liturgical Influence on John 6," $C B Q 22$ (1960): 183-191. For concise summary and critique of Gärtner's work, see esp. Kerr, Temple, 211-215, who surveys the parallels and concludes they are too weak to establish direct dependence. Note, also, the incisive, earlier critiques of Meeks, Prophet-King, 92 n. 2,; also Brown, 266-267, who regards the question-answer format as a characteristic Johannine technique (cf., e.g., 4:9/13, 11-12/14).

${ }^{244}$ Kerr, Temple, 214. Along similar lines, Brown, John, 245, rejects suggestions that the author has constructed the entire discourse from his own imagination to bring it into line with Passover themes; he argues instead that the many points of contact between Jesus' discourse and the OT ideas prevalent in contemporary Jewish liturgy during Passover season are best explained as indications of Jesus' intention to strike thematic chords that would be on the forefront of people's minds at that time.

${ }^{245}$ Kerr, Temple, 219 n. 36 and 220 n. 40.

${ }^{246}$ Hoskyns, John, 297; Grassi, "Eating”, 28; Godfrey W. Ashby, "Body and Blood in John 6:41-65," NeoT 36 (2002) 59; idem., Sacrifice: Its Nature and Purpose (London: SCM Press, 1988), 96; Kerr, Temple, 220 n. 40; Keener, John, 688; Hoskins, Temple, 177. Beasley-Murray, John, 87 (cf. 94), says that the Passover setting (6:4) as well as the Lamb of God logion (1:29) make the concept of the sacrifice of the Pascal lamb "fundamental to vv. 5158", while Bultmann, John, 156, believes the pascal orientation of the passage is so obvious as to indicate that the original note about the setting (6:4) was added by the same redactor who added 6:51-56.

${ }^{247}$ So, emphatically, Bruce, John, 158. Cf. Beasley-Murray, John, 94; Barrett, John, 298; Lindars, John, 267; Hoskyns, John, 297; Hoskins, Temple, 177; Smith, Theology, 116. Keener, 687, suggests "the future tense of 'give'
} 
Suffering Servant of Isa 53, while others argue for an association with the pascal lamb. ${ }^{248}$ For each, appeal is made to the surrounding context (i.e., the Passover setting or the citation of Isa 54 in John $6: 45)$ and it is probably best to retain both associations. ${ }^{249}$ If this is correct John 6:51 represents the second of three contexts in which John has conflated the Suffering Servant of Isa 53 and the pascal lamb (cf. 1:29 and the trial scene in 18:28-19:16). I suggested earlier that the reason for invoking both of these backgrounds to characterize the death of Jesus was to draw upon unique features of each tradition to illumine different facets of Jesus' death. In a word, it is his death as Suffering Servant which accomplishes the atonement for sin requisite for national restoration; and it is as the sacrificed pascal lamb that he supplies the Passover meal for the people to eat. ${ }^{250}$ I will argue in detail for this last point in my final section below.

I conclude by observing that considerable subtlety surrounds the presence of Passover throughout John 6 and its prominence must not be overstated. ${ }^{251}$ Notwithstanding this caveat, however, mention of the feast in John 6:4 represents a critical signal (or better, invitation) to read the feeding narrative against the backdrop of Passover. ${ }^{252}$ Furthermore, the hermeneutical relationship recognized by many scholars between the sign in 6:5-13 and the discourse in 6:26-58 justifies the expectation that the Passover background continues to play an important role in the remainder of the chapter. It seems, then, that the provision of food Jesus makes for the people is a symbolic pascal meal, and the food he provides is nothing other than his own flesh given to death as the pascal sacrifice. But to what end? I turn next to the way in which this pascal meal becomes oriented toward the national hopes of restoration.

\section{D.iii. Isaianic New Exodus theme in John 6}

\section{D.iii.1. Opening Miracle}

A second theme which spans the chapter as a whole is the Isaianic new exodus: Jesus' sacrificial death effects the deliverance prophesied in Isaiah and sought especially during Passover season. This theme is most clearly in evidence in the discourse section of the chapter. Nevertheless, the idea enters

in 6:51 (cf. 6:27) points forward to the passion", as do Gärtner, Passover, 24, and James D.G. Dunn, "John VI - A Eucharistic Discourse?" NTS 17 (1971) 331.

${ }^{248}$ For the former, see Carson, John, 295; Bruce, John, 158. For the latter, see Hoskyns, John, 297; Keener, John, 688; Borchert, John, 1.271; Beasley-Murray, John, 94.

${ }^{249}$ Carson, John, 295. As I argued above, these identities are also conjoined at 1:29 and in the trial scene before Pilate.

${ }^{250}$ Recall, again, the application of "blending theory" by Nielsen to show the purposeful "blending" of both backgrounds with a view toward the fuller characterization of Jesus' death (cf. "Lamb", 253, 255).

${ }^{251}$ As, perhaps, in Hoskyns, John, 281, quoted at the outset of this section.

${ }^{252}$ So, Meeks, Prophet-King, 92. 
into view already in the feeding account. ${ }^{253}$ The language of gathering and perishing as well as the highly symbolic number twelve in 6:12-13 have suggested to a number of commentators that the action symbolizes the restoration of the nation. ${ }^{254}$ Dennis observes, "the restoration of the twelve tribes of Israel was one of the common elements of Israel's eschatological expectation witnessed to in the OT prophets to the late Second Temple period." ${ }^{255}$ So pervasive was the expectation that the number

${ }^{253}$ Beasley-Murray, John, 88, sees evidence in 6:4, 14 and 31-33 that the feeding miracle falls "within the fulfillment of the hope of a second exodus" and "flows together" with the eschatological banquet of Isa 25:6-9. Yet he draws no attention to 6:12-13 which I will argue is critical for establishing this theme in anticipation of its fuller development in the discourse

${ }^{254}$ Cf. Wengst, Johannesevangelium, 221-222; Barrett, John, 277; Lincoln, John, 213 (tentatively, and noting the "stress on twelve" as the number of disciples at the end of the chapter); Carson, John, 271; Edmund Little, Echoes of the Old Testament in the Wine of Cana in Galilee (John 2.1-11) and the Multiplication of the Loaves and Fish (John 6.1-15) (Cahiers De La Revue Biblique. Paris: Gabalda, 1998), 148-149; and esp. Meeks, Prophet-King, 95-98; Dennis, "Exodus," 119-121; idem., Gathering, 194-200; Brunson, Psalm 118, 163; Webster, Ingesting, 71-72. This symbolic reading is rejected by Lindars, John, 243, and Keener, John, 669, who simply labels it "fanciful" and notes that in the discourse the bread stands for Jesus' body alone. Yet this overlooks the great symbolic force of the number twelve (see below) as well as the redactional emphasis given Jesus' command which contains precisely those elements which urge readers to a symbolic understanding of the scene ("gather" and "perish"). For the purposefulness of these changes to the Synoptic/Markan tradition, cf. Daube, New Testament, 36-46; Witkamp, "Features," 49; Brown, John, 247-248.

Some scholars have discerned in the terms $\sigma u v \alpha \dot{\gamma} \gamma \omega$ and $\epsilon \dot{\chi} \chi \alpha \rho\llcorner\sigma \tau \epsilon \omega$ indications of sacramental thought common in later, Christian sources. For example, Moloney, Signs, 35 [ = idem., "The Function of Prolepsis in the Interpretation of John 6," in Critical Readings of John 6 (ed. R. Alan Culpepper; Biblical Interpretation Series; Leiden: Brill, 1997) 132-133], cites uses of $\sigma u v \alpha$ ' $\gamma \omega$ in 1 Clem. 34:7, Ign. Pol. 4:2 and Did. 9:4 "in ways that indicate the gathering of the faithful at Eucharist" (similarly, Brown, 248). Although neither of the first two sources gives any indication of a Eucharistic setting (note the due caution of Barrett, John, 276-277, from whom Moloney borrowed the citations), Did. 9:4 represents a striking parallel to Jesus' command in John 6:12 and could be thought to attest the technical use of "gathering" terminology with reference to the Eucharist: "Even as this broken bread was scattered over the hills, and was gathered together and became one, so let Thy Church be gathered together from the ends of the earth into Thy kingdom; for Thine is the glory and the power through Jesus Christ forever" (vv.3, 5 clarify the sacramental orientation of the passage). C.F.D. Moule, "A Note on Didache IX.4," JTS 6 (1955) 240-243 (followed by Brown, John, 248, and Moloney, Signs, 35), has argued that John 6:12 formed the basis for the language and idea of the gathering of the Church in the Didache passage (common terms include $\epsilon \dot{\chi} \chi \alpha \rho\left\llcorner\sigma \tau \epsilon \epsilon, \sigma \nu \nu \alpha \dot{\gamma} \gamma \omega, \kappa \lambda \alpha^{\prime} \sigma \mu \alpha \tau \alpha\right.$; note also the mountain setting and reference to Kingdom/Kingship of Jesus). The weight of scholarly opinion since Moule's day is decidedly against this, however. Most recently, for example, Claussen has refuted the possibility of "textual dependence in one or the other direction" (Carsten Claussen, "The Eucharist in John and the Didache", in Trajectories thru the New Testament and the Apostolic Fathers (eds. Andrew F. Gregory and Christopher M. Tuckett; Oxford: Oxford University Press, 2005) 162; cf. Meeks, Prophet-King, 95 n.1). It seems best understand each as drawing on a common (Jewish) tradition, "so that John and the Didache can interpret each other" (Meeks, Prophet-King, 95). In this way the Didache represents not an early Christian interpretation of John 6:12-13, but an early Christian use of Jewish traditional categories along the same lines followed by John 6:12-13. In any case, later Christian use of the language of "gathering" or "giving thanks" is by no means indicative of technical use in the New Testament (see Bruce, John, 145; Schnackenburg, John, 2.17). Rather, usage in the Old Testament and contemporary Judaism (as argued above) should be preferred for determining technical usage. For further arguments against the Eucharistic interpretation, here, see e.g., Schenke, Johannes, 124, who concludes, "Es ist ganz unwahrscheinlich, daß die ersten Leser das nachösterliche Gemeindemahl nicht aus ständiger Praxis und eigener Anschauung kannten und mit ihm den Terminus Eucharistie verbanden."

${ }^{255}$ Dennis, Gathering, 194-195; cf. also 80-88 for a helpful correction of the conception of Jewish thought in, e.g., Wright, New Testament, 268-269. Dennis highlights the importance of distinguishing Assyrian and Babylonian exile in Jewish thought: whereas the former was ended with the return of many Jews to Palestine, the continued dispersion of so many Jews meant that the end of the former exile remained outstanding. For similar nuancing and 
twelve was virtually synonymous with restoration. ${ }^{256}$ Moreover, the activity of the disciples in 6:12-13 supports the symbolism of new exodus restoration. I will argue below that the feeding account as a whole is cast in terms of the wilderness provision under Moses in Num 11. It is sufficient for the moment to note the verbal allusions to this background both in Jesus' question of source (mó $\theta \in \nu$; cf. Num

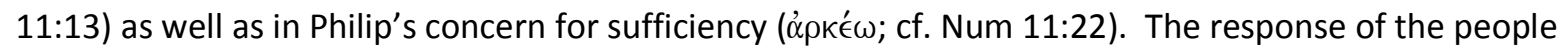
to this "sign" (John 6:14-15) also evokes the figure of the prophet-like-Moses who, I argued above, was associated with the eschatological new exodus. ${ }^{257}$ These exodus-new exodus elements in the narrative form the backdrop of the new exodus symbolism in 6:12-13.

On a linguistic level, "gathering", of course, is the language of restoration in the Old Testament. For example, in his vision of the eschatological restoration Isaiah says,

In that day the Lord will extend his hand yet a second time to recover the remnant that remains of his people, from Assyria, from Egypt, from Pathros, from Cush, from Elam, from Shinar, from Hamath, and from the coastlands of the sea. He will raise a signal for the nations and will assemble ( $\left.\sigma \cup \nu \alpha^{\prime} \xi \in l\right)$ the banished of Israel, and gather ( $\left.\sigma \nu \nu \alpha^{\prime} \xi \in l\right)$ the dispersed of Judah from the four corners of the earth. ${ }^{258}$

criticism of Wright (and others) along such lines, see Brant Pitre, Jesus, the Tribulation, and the End of the Exile: Restoration Eschatology and the Origin of the Atonement (WUNT; Tübingen: Mohr; Grand Rapids, Mich: Baker Academic, 2005), 31-41, and Steven M. Bryan, Jesus and Israel's Traditions of Judgement and Restoration (Society for New Testament Stud

ies Monograph Series, Cambridge: Cambridge University Press, 2002), 12-20.

256 "Denn die Zahl Zwölf kann nicht gut ohne Beziehung auf das Zwölfstämmevolk Israel gedacht werden, so dass Johannes die Gemeinde Jesu als Repräsentanz des restituierten und endzeitlichen Israel verstünde" (Wengst, Johannesevangelium, 221-222, who goes on to suggest that a Gentile-Christian context would read the symbolism in terms of the Church's replacement of Israel). Cf. also Sanders, Judaism, 98, and N.T. Wright, Jesus and the Victory of God (London: SPCK, 1996), 299-301, 430-431, 532. For the pervasive and contemporary expectation of the gathering of the twelve tribes in the eschatological salvation (often with the concomitant expectation of a renewed role for the twelve princes of Old Testament tradition), see also the extensive surveys of Jewish evidence in John P. Meier, A Marginal Jew: Rethinking the Historical Jesus, (The Anchor Bible Reference Library. New York: Doubleday, 1991), 3.148-163; idem., "Jesus, the Twelve, and the Restoration of Israel," in Restoration: Old Testament, Jewish and Christian Perspectives (ed. James M. Scott; Supplements to the Journal for the Study of Judaism; Leiden: Brill, 2001) 365-404 [esp. conclusion on 404: "The twelve symbolized and embodied the eschatological hopes of Israel and the eschatological message of Jesus: the restoration of all twelve tribes of Israel in the end-time."]; William Horbury, "The Twelve and the Phylarchs," in Messianism Among Jews and Christians (ed. William Horbury; London: T\&T Clark, 2003) 157-188 [esp. conclusion on p. 184]; Craig A. Evans, "Exile and Restoration," in Exile: Old Testament, Jewish and Christian Conceptions (ed. James M. Scott; Supplements to the Journal for the Study of Judais; Leiden: Brill, 1997) 317-318.

${ }^{257}$ Again, see Bauckham, "Messianism", 42-49; Keener, John, 70; Dennis, "Exodus", 109.

${ }^{258}$ LXX Isaiah 11:11-12. For other references to "gathering" the dispersed tribes, see Deut 30:1-4; Ps 107:2-3; Jer 31:8; 32:37; Ezek 36:24; Mic 2:12. 
An indication of the metaphorical import of this term in the more immediate Johannine context comes from Jesus' exchange with his disciples at 4:34-38 where Jesus instructed his disciples concerning their role in the mission of God. Using the metaphor of fields ready for harvest, he says they are to "enter into the labor" of those who came before them by gathering ( $\sigma u \nu \alpha \dot{\gamma} \omega)$ fruit "for eternal life". ${ }^{259}$ Importantly, this instruction is set against the scene of the people of Sychar "coming" to Jesus as wouldbe disciples. ${ }^{260}$ John 6:5 strikes a similar note when Jesus "lifts up his eyes and sees a great crowd coming to him." 261 Both the terminology of 6:5 and the scene strongly resemble the setting of 4:30-39. This parallel indicates that the narrative of 6:5-15 must be read in terms of the eschatological, missional framework of 4:34-38. ${ }^{262}$ The question to Philip, then, becomes programmatic for the scene, and indeed for the whole chapter. Jesus aims not simply to test his faith, but to offer a further lesson about the disciples' mission. ${ }^{263}$ Specifically, he instructs the disciples as to what it is they are to give to the people who are coming to Jesus hungry: they are to give them the food which Jesus will provide. Against the backdrop of 4:34-38, then, the activity of the disciples in 6:13 prefigures their future ministry of gathering believers in Jesus. ${ }^{264}$

In addition to these narrative cues, the language of perishing in 6:12 (" $\left.\nu \alpha \mu \eta \dot{\eta} \tau \iota \alpha \dot{\alpha} \pi{ }^{\prime} \lambda \eta \tau \alpha \iota\right)$ suggests Jesus has more in view than mere bread. Throughout the Gospel, with the exception of 6:12 and 27, "perishing" applies exclusively to people and designates the opposite of "eternal life". 265 Mention of "bread that perishes" at 6:27a manifestly refers to that which cannot promote eternal life in

\footnotetext{
${ }^{259}$ For the eschatological, restorational overtones of this image, see Keener, John, 625; Ridderbos, John, 169; and esp. Olsson, Structure, 241-248.

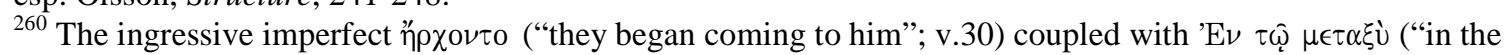
meantime"; v.31) combine to set the dialogue about the disciples' mission against the setting of approaching wouldbe believers (cf. 4:39). Schnackenburg, John, 1.448, believes Jesus' imperative "Look!" (v.35) is playing on the approach of the Samaritans in the distance. See also Barrett, John, 240; Lincoln, John, 180; Keener, John, 623; Köstenberger, John, 160 (following Daniel B. Wallace, Greek Grammar Beyond the Basics: An Exegetical Syntax of the New Testament with Scripture, Subject and Greek Word Index (Grand Rapids: Zondervan, 1996), 545).

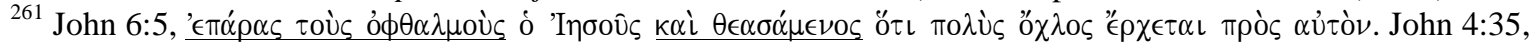

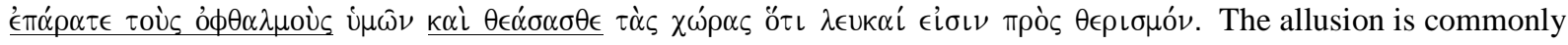
noted but seldom developed (e.g., Marsh, John, 283-284; Keener, John, 665; Brown, John, 233; though cf. Ridderbos, John, 210). The expression "coming to him", of course, is a well-known Johannine motif for faith (cf. Brown, John, 79) and the expression plays an important role later in the discourse about true belief in Jesus (cf. $6: 35,37,45)$. Keener, John, 665 , notes that the language of "following" Jesus already in v. 2 indicates that the issue of the crowd's discipleship to Jesus is critical to the setting of the narrative.

262 “...it evokes (as in 4:35) the messianic age" (Ridderbos, John, 210). Similarly, Lee, Symbolic, 138 and n. 3, and, at greater length, McWhirter, Bridegroom, 76-78.

${ }^{263}$ This is why Jesus directly involves the disciples, first by putting the pregnant question to Philip, then by giving them the symbolic instruction to gather the fragments (6:12-13). Cf. Ridderbos, John, 210, 213; Little, Echoes, 110 111, 148-149.

${ }^{264}$ Webster, Ingesting, 72; Barrett, John, 277.

${ }^{265}$ Dennis, Gathering, 197. Cf. John 3:16; 6:12, 27, 39; 10:10, 28; 11:50; 12:25; 17:12; 18:9.
} 
those who partake of it, as is evident from the antithetical statement in 6:27b. ${ }^{266}$ This leaves $6: 12$ as the singular occurrence of the term "perishing" in the Gospel that does not potentially refer to the greater spiritual reality in view in every other occurrence. However, the heavily symbolic nature of the miracle narrative, the missional orientation of the account, and the fact that it provides an illustrative basis for the discourse that ensues all strongly suggest that here, too, "perishing" refers to the absence of spiritual life. $^{267}$

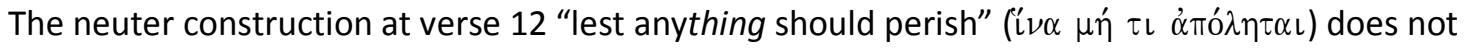
undermine this reading but in fact strengthens its likelihood. The neuter with $\dot{\alpha} \pi{ }^{0} \lambda \lambda \nu \mu \iota$ also occurs in the statements about perishing and rejection in the discourse (cf. 6:37, 39). ${ }^{268}$ Both the $\tau \iota$ of verse 12 and the $\pi \hat{\alpha} \nu$ ô and $\alpha \dot{u}$ tò of verse 39 are best understood as "generalizing neuter[s] for persons". ${ }^{269}$ Thus, Meeks is correct to view the phrase "lest any should perish" as "interpreted in verse 39 of the discourse" with reference to those given to Jesus by the Father. ${ }^{270}$

Finally, the symbolic action mentioned in 6:12-13 must not be understood as tangential to the main idea of the miracle narrative. On the contrary, the miracle account has been so arranged as to throw emphasis not on the miracle itself but on the gathering of the excess fragments. ${ }^{271}$ The notion of national ingathering from exile is central to the symbolism of the narrative. Thus, in the symbolism of the narrative, participation in this ingathering that Jesus effects is tacitly linked to the pascal meal he provides. I will define the relationship between these themes more precisely below.

\footnotetext{
${ }^{266}$ Barrett, John, 286; Carson, John, 284. John 6:49 represents a conceptual parallel to the food that perishes in 6:27a: "Your fathers ate manna in the wilderness, and they died."

267 "Just as the leftover pieces of bread are gathered and saved from perishing, Jesus' death 'for others' saves them from 'perishing' ( $\left(\dot{\alpha} \mathbf{c}^{\prime} \lambda \lambda u \mu \iota\right)$ in exile" (Dennis, Gathering, 200). Cf. also Borchert, John, 1.254, who notes the greater "theological" and symbolic significance of the term than is represented by "wasted" (NIV).

${ }^{268}$ In John 6:37, the neuter phrase "everyone that" parallels and is defined by the masculine phrase "the one who

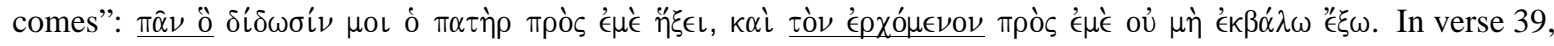

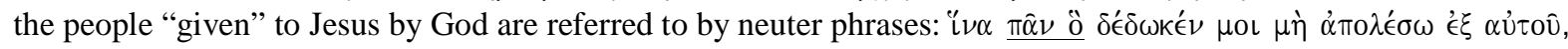

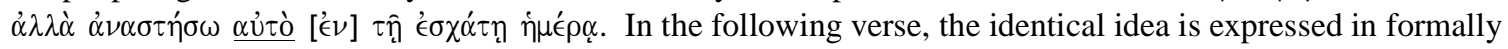

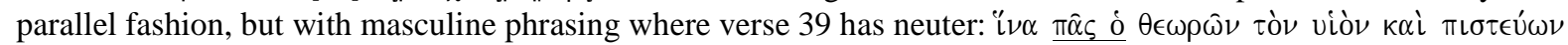

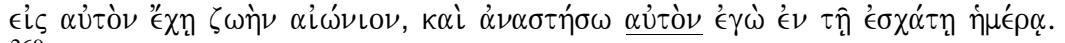

${ }^{269}$ Meeks, Prophet-King, 95 (citing BDF §138). Brown, John, 270, and Barrett, John, 294, argue for an intentional use of the neuter, here, to emphasize a "collective" nuance with the sense "the whole company" (contra Zerwick

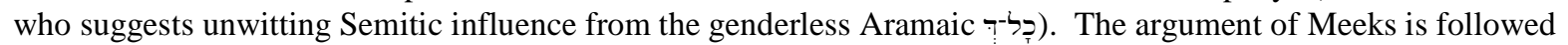
and expanded upon by Dennis, Gathering, 196-198.

${ }^{270}$ Meeks, Prophet-King, 95.

${ }^{271}$ Meeks, Prophet-King, 93-94 (following Daube, New Testament, 38), observes, "While the gathering of the superfluous fragments is part of the traditional form of the story...only in John is it introduced by a separate command by Jesus", and that the miracle itself is somewhat de-emphasized by being reduced to a subordinate clause ( $\dot{\omega} \delta \delta^{\epsilon} \dot{\epsilon}^{\epsilon} \nu \in \pi \lambda \eta \dot{\sigma} \sigma \theta \eta \sigma \alpha \nu$, v.12). This emphasis is also noted by Schnackenburg, John, 2.18, and Dennis, Gathering, 194.
} 


\section{D.iii.2. Development in discourse section}

The discourse develops the symbolism of the gathering of the pieces $(6: 12-13)$ in terms of the new exodus hope. ${ }^{272}$ Throughout the chapter the author evokes numerous traditions of the exoduswilderness period in order to re-interpret them in terms of the Isaianic new exodus hope. ${ }^{273}$ I have already noted the allusion to the provision of quail from Num 11 in the feeding narrative of John 6 (on which see further below). ${ }^{274}$ Some commentators discern echoes of the crossing of the Red Sea in Jesus' walking on the water in 6:16-21. ${ }^{275}$ The citation at John 6:31 invoking the manna tradition has often been traced to Exod 16:4 (or 15) or Ps 78:24 or both. ${ }^{276}$ The background is augmented by the motif of the Jews' complaining ( $\gamma \circ \gamma \gamma u ̛ \zeta \omega)$ against the agent of God. ${ }^{277}$ In this way, the manna tradition is expressly invoked and dominates the ensuing discourse through John 6:51. ${ }^{278}$

For the purposes of the present work, the background that has contributed most to the new exodus contours of the discourse is the climactic prophecy of Isa $55 .^{279}$ Burkett lists no fewer than thirteen verbal and thematic correspondences between John 6:27-62 and Isa 55:1-3, 10-11, and

\footnotetext{
${ }^{272}$ See, esp., Dennis, Gathering, 188-194 (which gives special attention to the new exodus theme).

${ }^{273}$ Dennis, "Exodus", 121; Brunson, Psalm 118, 155. For a succinct listing of exodus-wilderness correspondences across John 6, see Kerr, Temple, 214-215.

${ }^{274}$ Some scholars would add that the image of Jesus ascending and sitting on a mountain evokes Moses at Sinai. Cf. Yee, Feasts, 64.

${ }^{275}$ Esp. Hylen, John 6, 131-134. Also, Brown, John, 255; Yee, Feasts, 65-66; Dennis, "Exodus”, 114-115. All cite Ps 78:17-19 for its reference to the Red Sea crossing and note that such an allusion would be consonant with the citation of Ps 78:24 at John 6:31. Dennis, as well as Beasley-Murray, John, 89, suggests Jesus' words '́ $\gamma \omega^{\prime} \epsilon \dot{\imath} \mu \iota^{\circ} \mu \grave{\eta}$ $\phi о \beta \in \hat{\imath} \sigma \theta \epsilon$ may allude to Ps 77:17-20 (LXX 76:17-20) which describes the theophany of God when he led the people through the Red Sea in safety.
}

${ }^{276}$ See the survey of scholarship in M. J. J. Menken, Old Testament Quotations in the Fourth Gospel: Studies in Textual Form (Kampen: Kok Pharos, 1996), 49-54, and Swancutt, "Hungers", 225-230. Though some recognize verbal links to both (e.g., Schenke, Johannes, 134), the current consensus seems firmly set on Ps 78:24 as the primary source. Cf. Lagrange, Jean, 175; Westcott, John, 1.226; Morris, John, 363; Ernst Haenchen, John 1: A Commentary on the Gospel of John, Chapters 1-6 (Philadelphia: Fortress Press, 1984), 290; and esp., Margaret Daly-Denton, David in the Fourth Gospel: The Johannine Reception of the Psalms (Leiden: Brill, 2000), 131-144, and Georg Geiger, "Aufruf an Rückkehrende Zum Sinn des Zitats von Ps 78,24b in Joh 6,31," Bib 65 (1984) 449464. Geiger makes a detailed investigation of the grammar, themes and theology of Ps 78 and concludes, "Abgesehen vom Zitat Ps 78,24b finden sich in Joh 6 eine Menge auffallender Parallelen zum ganzen Ps 78" ("Joh 6,31 ", 459; see 459-461 for discussion of verbal and theological parallels).

${ }^{277}$ Cf. John 6:41, 61 with Exod. 15:24; 16:2, 7, 8; 17:3; Num 11:1; 14:2, 27-29, 36; 16:41; 17:5. See Brown John, 233, 270; Keener John,684; Little, Echoes, 128-129; Brunson, Psalm 118, 158; Dennis, "Exodus”, 117; Webster, Ingesting, 82; Hylen, John 6, 149-150; and esp. the extensive survey of the background of Num 11 and 14 throughout John 6:26-58 in Presian R. Burroughs, "Stop Grumbling and Start Eating: Gospel Meal Meets Scriptural Spice in the Bread of Life Discourse," HBT 28 (2006): 73-94.

${ }^{278}$ Again, note Hylen, John 6, 135-145.

${ }^{279}$ The argument is made by Carson, John, 289; Brown, John, 521; Little, Echoes, 122-125; and in detail by Swancutt, "Hungers", 234-248, and Delbert Burkett, The Son of the Man in the Gospel of John (Journal for the Study of the New Testament Supplement; Sheffield: JSOT Press, 1991), 129-141. Thyen, Johannesevangelium, 346348 , regards the discourse as a whole as "in viel engerer Beziehung" with Isa 55 than the wisdom texts sometimes discerned in the background (e.g., Sir 24:21; Pro 9:5). 
concludes, "the central theme of the discourse, the bread of life which has descended from heaven, stems from an identification of Jesus with the Word of God of Isa 55." ${ }^{280}$ Most importantly, Isa 55:1-3, 10-11 has supplied John 6:27, the verse that sounds the keynote for the discourse, with the imperative to seek the bread which fully satisfies over against that which perishes. ${ }^{281}$ While there is little direct linguistic overlap between John 6:27 and Isa 55:1-3, the essential themes of eating and satisfaction as well as the imperatives to seek good food "that your soul may live" have shaped Jesus' exhortation to

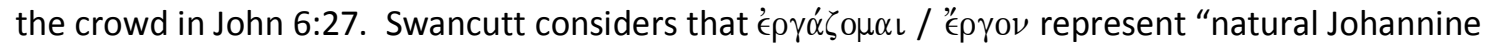

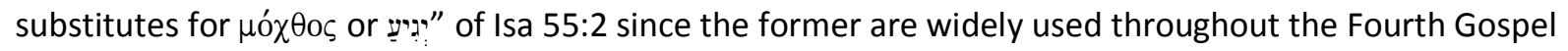

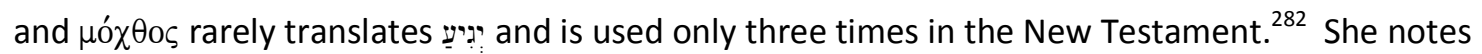

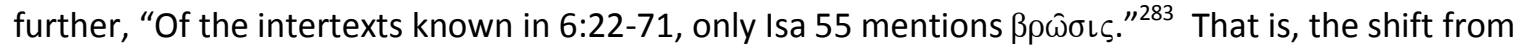

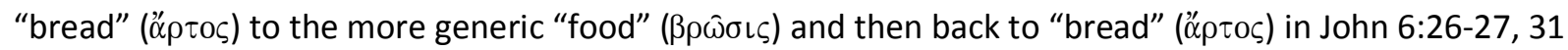
(cf. 6:55) is likely attributable to John's appropriation of $\beta \rho \omega \hat{\sigma} \iota \varsigma$ from Isa 55:10-11 "when he did not find ״̈pros at Isa 55:1-2." ${ }^{284}$ Burkett explains, "The food which the Word of God gives is in fact the Word itself, which one assimilates by hearing and which gives life to the hearer (Isa 55:1-3). In speaking of giving the food which remains for eternal life, therefore, Jesus is speaking as the Word of God." ${ }^{285}$ Thus, by means of the reworked invitation of Isa 55:1-2, John 6:27 "forecasts the $\tau \dot{\epsilon}$ ' $\lambda \circ \varsigma$ of the Johannine discourse." 286

In addition to the opening imperative of John 6:27, other points of contact with Isa 55 include

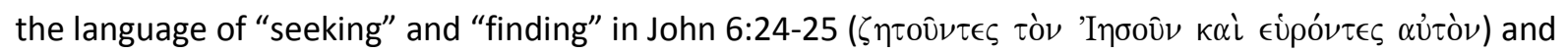

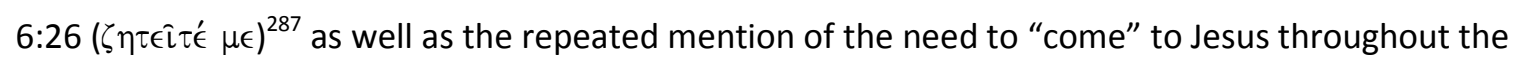
discourse $\left(6: 35,37,44,65 ;\right.$ cf. Isa 55:1). ${ }^{288}$ The ascent/descent motif that occurs seven times in the

\footnotetext{
${ }^{280}$ Burkett, Son, 132.

${ }^{281}$ So Lincoln, John, 226; Bernard, John,1.191; John L. Ronning, "The Targum of Isaiah and the Johannine Literature," WTJ 69 (2007) 255-256; and esp. Burkett, Son, 134-135, and Swancutt, "Hungers”, 236-239.

282 "Hungers", 236 n. 58.

283 "Hungers", 238.

${ }^{284}$ Ibid. Burkett, Son, 134, concludes similarly: "The 'food' which the Son of Man will give is the food given by the

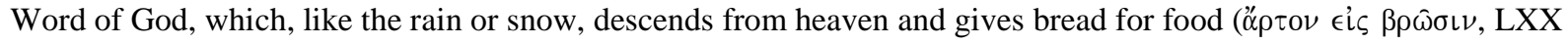
Isa 55:10)."

285 Son, 134-135.

${ }^{286}$ Swancutt, "Hungers", 239.

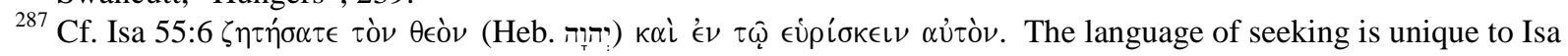
55 among the Old Testament backgrounds in John 6. Swancutt, "Hungers", 240, believes the author uses this allusion ironically, for upon "finding" Jesus the crowd addresses him as 'teacher'. In verse 34 the crowd finally calls him kúpıє "but do not know what they have said."

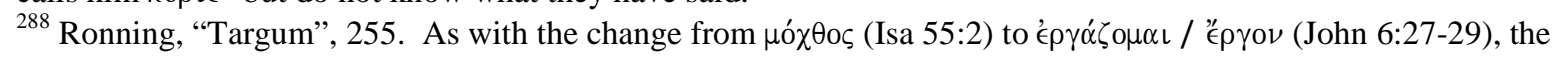

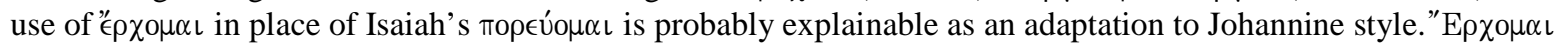
commonly carries connotations of discipleship in John and as such more naturally represents the invitation of Isa
} 
discourse (cf. 6:33, 38, 41-42, 50-51, 58) cannot be accounted for linguistically by either Exod 16 or Ps 78 , the main passages thought to stand behind the discourse from John 6:31 onward. The motif most likely originates with Isa 55:10: "as rain or snow come down from heaven and do not return until they cause the earth to bud and flourish and give seed to the sower and bread for food...." 289 This may also

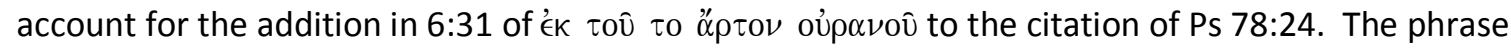
occurs in none of the suggested backgrounds to John 6:26-58 except Isa 55:10 and likely constitutes Johannine addition arising from the author's widespread use of Isa 55:10-11 for the ascent-descent motif. ${ }^{290}$ Indeed, the picture that begins to emerge throughout the discourse is of the conflation of the vocabulary and themes of Ps 78 and Isa 55. Burkett, in fact, argues that this is because Jesus is not disputing the reading of Ps 78 by the Jews but rather setting it against Isa $55 .{ }^{291}$

In John 6,31-33, then, the contrast is between the manna, called 'bread from heaven' in the verse quoted by the Jews, and the Word of God of Isa 55, which Jesus refers to as the 'true bread from heaven.' Jesus does not dispute that the passage cited by the Jews refers to the manna given in the past to the fathers. Rather, he denies that the manna...was the true bread from heaven...That bread did not give life. The true bread from heaven is the Word of God of Isa 55, which does give life."292

John, then, has drawn upon key images from the first exodus and wilderness wandering (filtered through Ps 78) and interpreted them within the framework of the new exodus hope of Isa 55. By this means he represents Jesus as the provider of the food and drink that lead to life. ${ }^{293}$ Moreover, when it is recalled that John 6:26-27 opens the discourse by referring to the pascal meal symbolically provided by Jesus in 6:5-11, the introduction of Isa 55 into the very heart of the discourse effectively conflates the

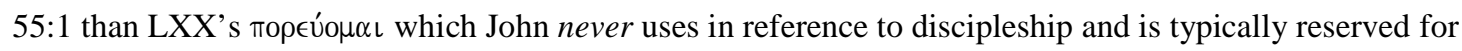
departure, of Jesus in death or of others in a more banal spatial sense.

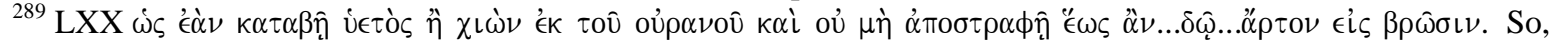
also, Burkett, Son, 141, and Thyen, Johannesevangelium, 347-348.

${ }^{290}$ Swancutt, "Hungers", 227-228; Burkett, Son, 141; see also John V. Dahms, "Isaiah 55 and the Gospel of John," EQ 53 (1981) 78-88.

${ }^{291}$ Contra Peder Borgen, Bread from Heaven: An Exegetical Study of the Concept of Manna in the Gospel of John and the Writings of Philo (Supplements to Novum Testamentum; Leiden: E.J. Brill, 1965), 59-67, who argues that Jesus disputes the Jews' interpretation of Ps 78 by means of a different vocalization of the Hebrew text.

${ }^{292}$ Burkett, Son, 133.

${ }^{293}$ Swancutt, "Hungers", 246, concludes, "The Johannine interweaving of Psalm 77's wilderness narrative and the Isaian new exodus prophecy results in the recombination of past and present covenant promises that explains Jesus' soteriological significance." 
pascal meal with the eschatological meal of Israel's restoration. ${ }^{294}$ In this way John signals that the true pascal meal Jesus would provide was nothing short of the means by which one might participate in the eschatological new exodus of Isaiah.

The crucial point to note is that new exodus life is mediated by the gift of food provided by Jesus. This is the same conceptual pattern as in the feeding story (though the precise relation was less clear at that point): Jesus supplies the food which the disciples are to give the people so that they may participate in the eschatological ingathering of the nation.

\section{D.iv. Provision through Jesus' death}

I have argued that the feeding of the crowd has been cast as a replacement Passover meal and that this thematic backdrop supplies the context essential for understanding both the opening narrative and the discourse section that follows. The author signals his main interest by the question Jesus poses to Philip: "From where shall we buy bread that they may eat?" At the heart of the question is the problem of source $(\pi o ́ \theta \in \nu)$. The Passover and restoration themes described above allow the question to be further sharpened: What is the source of the pascal meal which brings the Isaianic new exodus restoration? I will take up the significance of the pascal meal below. First, however, I must clarify the answer to this question of source which is programmatic for the entire chapter.

The answer to the question is indicated within the feeding narrative by the miracle itself: Jesus will supply the needed food for the people. ${ }^{295}$ This conclusion is refined by recognition of several points of contact between John 6:5-13 and Num 11:13, 18-23 which suggest the exchange between Jesus and Philip was tailored to recall the exchange between Moses and the Lord. ${ }^{296}$ In particular, the concept of

\footnotetext{
${ }^{294}$ Some commentators already perceive the presence of eschatological meal-imagery in 6:5-11. Cf. BeasleyMurray, John,88, and Lincoln, John,216, who cite Isa 25:6-9 and 2 Bar. 29:5-8. Margaret Daly-Denton, David in the Fourth Gospel: The Johannine Reception of the Psalms (Leiden: Brill, 2000), 139-140 (cf., also, Witherington, John, 156), argues for the influence of the Jewish interpretation of the Passover meal as an eschatological Messianic banquet modeled after the manna story (citing an interpretation of Ps 72:16 attributed to R. Eliezer ben Hyrcanus in S.S. Rab. 1.18). The dating of such a linkage is open to question, however.

${ }^{295}$ Webster, Ingesting, 68.

${ }^{296}$ Noted (though not developed) by, e.g., Hylen, John 6, 124-125; Little, Echoes, 120, 130, 139-140. The Numbers

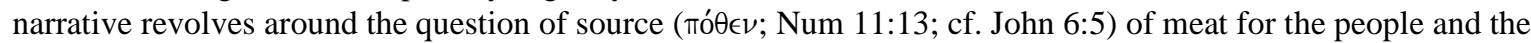

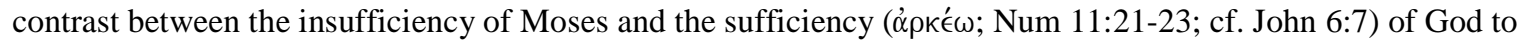
provide for this need. Noteworthy, also, are mention of the vast size of the crowds, thereby highlighting the scope of the miracle (Num 11:21; John 6:10), and the initial consideration of the situation (by Moses/Philip) from purely human perspective (Num 11:21-22; John 6:7). The language of "gathering" ( $\sigma u v \alpha \gamma \gamma \omega$; Num 11:22; John 6:12-13) is also common to both contexts, though the usage is not precisely parallel. The allusion is made more probable by the generally recognized Mosaic backdrop of the scene in John 6 created both by the foregoing (5:45-47) and immediate (6:3) narrative contexts. It should be noted, here, that the parallelism between Num 11 and John 6 precludes any notion of Jesus superseding or replacing Moses as the people's provider (contra, e.g., Yee, Feasts, 64, 66). In the logic of John 6, God himself was set in contrast to Moses in the original narrative of Num 11. The parallelism is not
} 
the "sufficiency" of God to meet the needs of the people of Israel in the desert appears to have been appropriated by the Evangelist in his portrayal of Jesus in the scene. Such an allusion, if granted, sharpens the idea of Jesus' sufficiency to supply the people's need by likening it to the sufficiency of God to supply the wilderness generation.

This idea receives elaboration in the discourse section as Jesus is expressly made the source or provider of "the food that endures to eternal life" (John 6:27; cf. 6:33, 51). It may be that the Ps 78 citation in John 6:31 also contributes to this idea. Swancutt has noted that the question of the Jews in

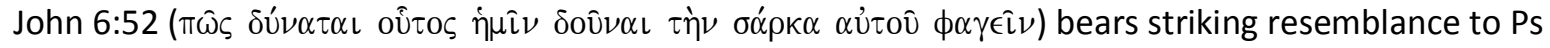

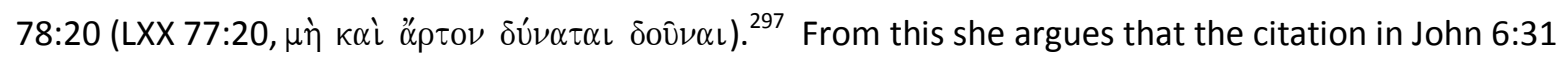
does not merely provide language descriptive of the Mosaic wilderness experience, but adds an important thematic element from the Psalm: the faithlessness of the Israelites who test God and question his ability to provide for their needs. Psalm 78 seems to function in parallel fashion to Num 11 by carrying forward the theme of Jesus' sufficiency as the source of food for the people.

As the discourse develops, this motif of Jesus-as-provider expands to include Jesus-as-provision, as well. In verse 33 he declares, "the bread of God is he who comes down from heaven and gives life to the world". This becomes more emphatic in verse 35 (and cf. v.48), "I am the bread of life. The one who comes to me shall not hunger, and the one who believes in me shall never thirst." ${ }^{298}$ This conflation of provider and provision persists for the rest of the discourse, becoming clearest at verses 50-51: "This is the bread that comes down from heaven, so that one may eat of it and not die. I am the living bread that came down from heaven. If anyone eats of this bread, he will live forever. The bread which I will give for the life of the world is my flesh." The final clause (v. 51c) forms the pinnacle to which the thought has been building all along: the food Jesus provides is nothing short of his own flesh given over to death as the paschal sacrifice. As the climactic statement of the chapter, John 6:51 provides the

contrastive but comparative: Philip stands in the role of Moses, and Jesus in the role of God. The emphasis in John's portrayal of Jesus, then, is not on any supersession of Moses, but rather in his likeness to God himself as the one who is sufficient to provide for the people's ultimate need.

297 "Hungers", 229-230. The connection becomes more probable in light of the response of God described in Ps

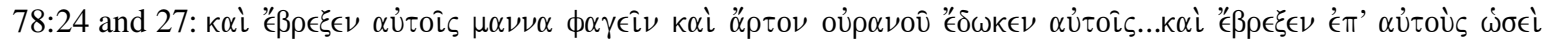

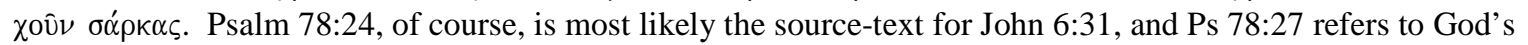

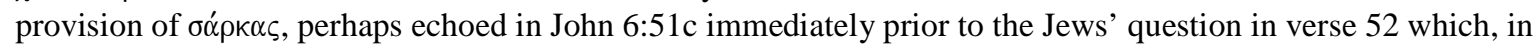
turn, evokes Ps 78:20.

${ }^{298}$ The step from "giver" to "given" in vv. 32-35, is recognized, for example, by Schuchard, Scripture, 44. KarlGustav Sandelin, Wisdom as nourisher : a study of an Old Testament theme, its development within early Judaism and its impact on early Christianity (Abo : Abo Akademi, 1986), 178, points out that the concept of Jesus as both provider and provision of heavenly food is parallel to Sir 24:19-21, a passage commonly thought to have contributed (together with Pro 9:1-6) to John's thought throughout 6:22-51 (e.g., Witherington, John, 149-150). Wisdom, in Sir 24 , at once offers nourishment, and is herself "an object of desire." 


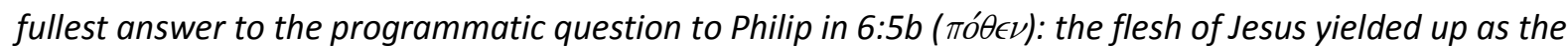
paschal sacrifice becomes the source of the pascal meal. Jesus effects the gathering of the new Israel by giving his flesh to be consumed by those who would become his disciples and thereby participate in the restored community of God's people. ${ }^{299}$

\section{E. Symbolic meaning of the pascal meal}

I have tried to establish that the chief emphasis in John's use of the Passover tradition lies on the eating of the pascal meal. Moreover, I argued that this pascal meal Jesus provides becomes intertwined with the establishment of the new exodus effected by his sacrificial death. What symbolic significance from Passover tradition accounts for the author's use of it in this way? ${ }^{300}$ In what follows, I will turn to the final stage of my argument, namely, the idea that the crucial dimension of the Passover symbolism appropriated by John is the idea that participation in the pascal meal is constitutive of one's participation and membership in the (restored) people of God.

\section{E.i. Jewish Background}

Throughout the second Temple period, and even before it, participation in the Passover festival, and eating the lamb in particular, was regarded as critical to continued membership in the community of God's people (and in some cases for entrance into it). ${ }^{301}$ The great importance attached to participation in the festival is evident already in Num 9:13: "if anyone who is clean and is not on a journey fails to keep the Passover, that person shall be cut off from his people because he did not bring the LORD's offering at its appointed time; that man shall bear his sin." Failure to properly observe the festival leads to removal from the covenant community. ${ }^{302}$

\footnotetext{
${ }^{299}$ Kerr, Temple, 225, comes close to this conclusion: "In this sense Jesus is the new Moses, who has inaugurated a new Passover in his own flesh and blood and a new exodus with a manna that gives eternal life."

${ }^{300}$ Some commentators suggest the graphic image of eating Jesus' flesh and drinking his blood is indicative of the intimacy of relationship between Jesus and the disciples (cf. Westcott, John, 1.238-239. Beasley-Murray, John, 95, and Bruce, John, 160, appeal to the conceptual parallel in Paul's thought, esp. Gal 2:19-20). This is undoubtedly true, yet it does not explain the specific association with the pascal meal.

${ }^{301}$ Routledge suggests this communal significance may have been an outworking of the centralization of the festival at the Temple. "The change in emphasis from the original event, which focused on individual families in their homes, to its commemoration as a public celebration for which the whole nation came together, may have been significant. After the covenant at Sinai, Israel was no longer to regard itself as an unconnected gathering of families and clans but as one people. The gathering of the people to celebrate the Passover symbolized the fact that they were now one family — the family of God" (Robin Routledge, "Passover and Last Supper," TynB 53 (2002) 207, citing Peter C. Craigie, The Book of Deuteronomy (The New International Commentary on the Old Testament; Grand Rapids: Eerdmans, 1976) 242).

${ }^{302}$ See the discussion in Philip J. Budd, Numbers (Word Biblical Commentary; Waco: Word Books Ltd, 1984) 9899.
} 
In the post-exilic account of the celebration of Passover under Hezekiah (2 Chr 30), participation in the festival is directly linked to community membership. ${ }^{303}$ In the wake of years of idolatrous practices under the reign of Ahaz (2 Chr 28:22-27), Hezekiah's program of purging of the Temple of idolatrous implements and re-establishment of proper worship carried far greater import than a mere religious reform. The charge the king gave the Levites to perform this cleansing work opens by setting the work in its historical and theological context. He says,

Our fathers were unfaithful; they did evil in the eyes of the LORD our God and forsook him. They turned their faces away from the LORD's dwelling place and turned their backs on him. ${ }^{304}$

The idolatry which defiled the Temple was no mere accretion from procedural norms in Temple worship, it represented a wholesale turning away from the covenant relationship with God. ${ }^{305}$ For this reason, Hezekiah aims at nothing short of a reconstitution of the covenant community and its relationship with God (29:10). ${ }^{306}$ To this end, he offers sacrifices to atone for the sins of the "kingdom" and for "all Israel" (29:21-24) and summons the whole land (both north and south!) to gather at Jerusalem to celebrate Passover as a seal of their "return" to the Lord $(30: 6,9)$.

The holistic vision of the king is striking. Evidently, the recent sack of Samaria by the Assyrians ( $2 \mathrm{Chr} 30: 6-7$ ) and the looming threat to Judah prompted the king to call for a unified return to the Lord at the very point where the nation's sin was most egregious, the Temple. ${ }^{307}$ If Judah had "closed the

\footnotetext{
${ }^{303}$ In what follows I will briefly examine the Passovers celebrated in 2 Chr. 30, 35 and Ezra 6. The accounts have most likely been shaped by a common author, or at least a common tradition. This is evident, for example, from the fact that 2 Chr 35 more nearly resembles Ezra 6:19-22 than 2 Kgs 23:21-23 on which it is ostensibly based. For reconstruction of the history behind these accounts as well as the literary relationships between them, see H. G. M. Williamson, 1 and 2 Chronicles, New Century Bible Commentary (Grand Rapids, Mich: Eerdmans, 1982), 360-365, and Alan Segal, The Hebrew Passover: From the Earliest Times to A.D. 70 (London: Oxford University Press, 1963), 10-19, 225-230.

${ }^{304} 2$ Chronicles 29:6.

${ }^{305}$ The covenantal/exilic pattern of thought is evident from the reference to "the God of your fathers" (29:5), the title "Lord your God" and the language of unfaithfulness (on which see Williamson, 1 and 2 Chronicles, 353). Sara Japhet, I \& II Chronicles: A Commentary, The Old Testament Library (Louisville, Ky: Westminster/John Knox Press, 1993), 944, notes, also, that the "rare and solemn epithet" in 30:6 "the God of Abraham, Isaac and Israel" evokes the unity of the northern and southern tribes and their common identity as the people of the covenant God (cf. the similar form of the epithet in the revelation to Moses in Exod 3:6, 15; 4:5).

${ }^{306}$ Notwithstanding Hezekiah's express desire to "make a covenant with the Lord" (29:10), it is doubtful that any kind of formal covenant-making ceremony took place. See Japhet, $1 \& 2$ Chronicles, 919; Williamson, 1 and 2 Chronicles, 354; William Johnstone, 1 and 2 Chronicles Vols 1,2 (Journal for the Study of the Old Testament Supplement; Sheffield: Sheffield, 1997), 2.191-192.

${ }^{307}$ Japhet, 1\&2 Chronicles, 944, points out that the title "God of Abraham, Isaac and Israel" suits the unitive purpose of Hezekiah's letter well. Both the name "Israel" (in lieu of "Jacob", father of the twelve patriarchs) as well
} 
doors of the Temple" and given itself over to idolatry (cf. 2 Chr 28:22-27; 29:3-11) and in this way brought itself to the brink of destruction at the hand of Assyria, Samaria just now succumbed to this very fate for its persistent rejection and abandonment of the Jerusalem Temple. ${ }^{308}$ By inviting "all Israel", both north and south, to come to the Temple to celebrate Passover Hezekiah aims to reunite the kingdoms around Temple worship. ${ }^{309}$

For present purposes, the important point is the way in which Passover fits into this narrative of the reconstitution of the covenant community. Following completion of the cleansing of the Temple and restoration of proper worship, the king decides to summon all the people "to keep the Passover in the second month - for they could not keep it at that time because the priests had not consecrated themselves in sufficient number and the people had not assembled in Jerusalem" (2 Chr 30:2-3). When the king sends out the proclamation "to all Israel and Judah" to come to Jerusalem to observe Passover he frames it from first to last in terms of returning to the Lord.

People of Israel, return to the LORD, the God of Abraham, Isaac and Israel, that he may return to you who are left, who have escaped from the hand of the kings of Assyria. Do not be like your fathers and brothers, who were unfaithful to the LORD, the God of their fathers, so that he made them an object of horror, as you see. Do not be stiff-necked, as your fathers were; submit to the LORD. Come to the sanctuary, which he has consecrated forever. Serve the LORD your God, so that his fierce anger will turn away from you. If you return to the LORD, then your brothers and your children will be shown compassion by their captors and will come back to this land, for the LORD your God is gracious and compassionate. He will not turn his face from you if you return to him. ${ }^{310}$

The summons to partake in the Passover celebration is framed in terms of a return to covenant faithfulness after a period of apostasy through idolatry and consequent punishment in exile. ${ }^{311}$ Also

as the allusion made by this epithet to the original revelation of God to Moses in Exod 3 highlights the shared historical and religious origins of the kingdoms.

${ }^{308}$ The Chronicler evidently viewed the establishment of a new cult at the beginning of the Northern Kingdom as the essential sin for which the North was finally deprived of its monarchy (Japhet, 1\&2 Chronicles, 943-944).

309 "For the Chronicler's post-exilic audience the lesson could not be clearer: the path to restoration and blessing was the path of cultic fidelity" (Raymond Dillard, 2 Chronicles (Word Biblical Commentary; Waco, Tex: Word Books, 1987), 234).

${ }^{310}$ Second Chronicles 30:6-9.

${ }^{311}$ See further, on this, the treatment of John C. Endres, "Theology of Worship in Chronicles," in The Chronicler as Theologian: Essays in Honor of Ralph W. Klein (eds. M. Patrick Graham, Steven L. McKenzie and Garry N. Knoppers; Journal for the Study of the Old Testament Supplement Series 371; London: T \& T Clark, 2003) 181-186. 
noteworthy is the inclusion of the northern kingdom in the event: even for those who existed for a long time outside the covenant community may enter by joining in the observance of this festival. ${ }^{312}$ Coming to Jerusalem to celebrate Passover is imperative for those who would join the king in re-establishing the covenant relationship with the Lord for observance of the festival functions as the enactment of this return to the Lord and so reconstitutes the entire covenant community (both kingdoms). The observance of Passover is even made the pre-requisite for the gathering back to the land of those already in exile: "If you return to the LORD, then your brothers and your children will be shown compassion by their captors and will come back to this land" (30:9). ${ }^{313}$

The same pattern of thought is evident in the account of Josiah's program of cleansing not only the Temple but all the land in $2 \mathrm{Chr} 34-35$. Josiah, like Hezekiah, sought to restore the covenant relationship between the people and the Lord since the people had "forsaken" the Lord (34:25). Therefore, he gathered together all the leaders and inhabitants of Jerusalem, read the "Book of the Law" and "made a covenant before the Lord" (2 Chr 34:29-31). He then made all the people of Israel "pledge themselves to it" and "serve the Lord their God" (2 Chr 34:33). ${ }^{314}$ It is in the context of this renewal of the covenant relationship between God and "the people of Israel" that the king reportedly celebrated a Passover (2 Chr 35). Though not made explicit as in $2 \mathrm{Chr} 30$, the function of Passover as enactment of covenant restoration is clear in the repeated emphasis that the festival was observed in accordance with the command of the (newly discovered) book of Moses (cf. $2 \mathrm{Chr} 35: 6,12$ ). Indeed, the entire chapter invokes figures and institutions from Israel's past in a way which has "the effect of linking the celebration of Josiah with the foundations of Israel's worship" ${ }^{315}$ The broad narrative pattern

The pun on the Hebrew term for "return" (שוב) as well as broader themes of exile and restoration throughout $2 \mathrm{Chr}$ 30:6-9 reveal the influence of the prayer of Solomon in $1 \mathrm{Kgs} 8$ and by the prophets (esp. Jeremiah). See Dillard, 2 Chronicles, 242-243, 245; Williamson, 1 and 2 Chronicles, 367-368; Johnstone, 1 and 2 Chronicles, 2.201.

312 Japhet, $1 \& 2$ Chronicles, 1044-1045, argues that the whole purpose of Hezekiah's Passover "was to provide a cultic-religious framework for the integration of the people of the North into the Jerusalem cult". An essentially ad hoc event, she suggests, its report in $2 \mathrm{Chr} 30$ is dominated by concern for the approach of and accommodation for the Northern Israelites.

${ }^{313}$ Simon J. DeVries, 1 and 2 Chronicles, (The Forms of the Old Testament Literature; Grand Rapids: Eerdmans, 1989), 380; Endres, "Worship", 185.

${ }^{314}$ See the translation and discussion of Dillard, 2 Chronicles, 274, 282, and DeVries, $1 \& 2$ Chronicles, 411 . The covenant made by the king was, of course, not a new agreement between the people and God, but "a covenant to keep the covenant" first established under Moses (Johnstone, 1 and 2 Chronicles, 2.244; and see, esp., Japhet, $1 \& 2$ Chronicles, 1036 ).

${ }^{315}$ William Riley, King and Cultus in Chronicles: Worship and the Reinterpretation of History (Journal for the Study of the Old Testament Supplement. Sheffield: JSOT Press, 1993), 135. Riley, in fact, argues that the Chronicler represents the celebration under Josiah as more spectacular than previous celebrations because the newly rediscovered book of the Law made possible "the fullest possible covenant relationship according to the Mosaic Law" in many generations. The celebration of Passover, then, signaled the achievement of a "cultic height" never before reached during the divided monarchy (Cultus, 136, and see 134-138). This reading reinforces the significance of the festival for the Chronicler as an enactment of participation in the (restored) covenant community. 
renewal of covenant--reconstitution of community--celebration of Passover further suggests that Passover functions in the same capacity in the Josiah narrative as it did in the narrative of Hezekiah.

The Passover account in Ezra 6:19-21 represents, "the third new beginning marked by the celebration of this festival with the participation of all the people" in the Chronicler's history as a whole. ${ }^{316}$ I will treat this account more briefly, essentially noting the same basic pattern of thought as in the prior two. Following completion of the Temple, Ezra 6:21 explains that the Passover "was eaten by the people of Israel who had returned from exile, and also by everyone who had joined them and separated himself from the uncleanness of the peoples of the land to worship the LORD, the God of Israel." As in the narratives of Chronicles examined above, a direct connection is formed between eating the Passover meal and participation in the restored covenant community. ${ }^{317}$ Moreover, as in Hezekiah's celebration, the festival becomes an occasion for the inclusion of those who formerly existed outside the covenant community. Though scholars have debated the identity of these people "who had joined them" after separating themselves from "uncleanness", their inclusion strengthens the linkage between the festival and community membership. ${ }^{318}$ Once again, therefore, Passover and community participation are closely linked.

In Jub. 49 the legislation for observing the annual Passover provided by the author naturally forms a selective representation of the Biblical material. Those details that he sees fit to include, then, can be viewed as of special importance. ${ }^{319}$ In Jub.49:9 the author gives priority warning the people not to fail to observe the Passover.

As for the man who is purified and does not come so that he might observe it on its appointed day to bring a gift which is acceptable before the Lord and to eat and drink before the Lord on the day of his feast, that man who is purified and nearby shall be uprooted because he did not bring a gift of the Lord in its time. ${ }^{320}$

\footnotetext{
${ }^{316}$ Joseph Blenkinsopp, Ezra-Nehemiah (Old Testament Library; London: SCM, 1989), 132.

${ }^{317}$ The emphasis on restoration is evident in the reference to the people in verse 19 as "the returned exiles".

${ }^{318}$ Such inclusion of outsiders was envisioned in the Passover legislation of Exod 12:43-49 and Num 9:14. Scholars commonly highlight the inclusivity of this occasion amid a developing theme of exclusivity across Ezra and Nehemiah as a whole. See, e.g., Mark A. Throntveit, Ezra-Nehemiah (Interpretation; Louisville, Ky: John Knox Press, 1992), 36; F. Charles Fensham, The Books of Ezra and Nehemiah (New International Commentary on the Old Testament; Grand Rapids, Mich: Eerdmans, 1982), 96; and esp., Blenkinsopp, Ezra-Nehemiah, 133.

${ }^{319}$ For further discussion of the representation of the Passover celebration in Jub. 49, see Segal, Passover, 19-23.

${ }^{320}$ Jubilees 49:9.
} 
This statement is noteworthy in the context of our discussion since it highlights the injunction of Num 9:13 which makes eating the Passover every year requisite for continued membership in the covenant community (the italicized words represent the author's insertion into the Biblical text). The accounts of Passover under Hezekiah, Josiah and Ezra are set against a radical renewal of the covenant community in its relationship with God. Jubilees, however, focuses upon the annual festival. ${ }^{321}$ Jubilees, therefore, reveals the continued prominence of the legislation of Num 9:13 for the annual festival. For Jubilees, the paschal meal must be eaten every year if one is to remain a part of the redeemed community.

Evidence for the correlation of Passover observance with community membership in the $1^{\text {st }}$ century C.E. may be found in Josephus' retellings of the stories of the Passovers celebrated under Hezekiah and Josiah. For example, Hezekiah's proclamation to come to Jerusalem to observe Passover becomes even more clearly linked with the renewal of the covenant relationship with God and the reconstitution of the people as the community of the covenant. ${ }^{322}$ Josephus reports,

He also sent to the Israelites, and exhorted them to stop their present way of living, and return to their ancient practices, and to worship God, for that he gave them permission to come to Jerusalem, and to celebrate, all in one body, the feast of unleavened bread ${ }^{323}$

Of those who heeded the king's proclamation Josephus says,

many there were of the tribe of Manasseh, and of Zebulun, and of Issachar, who were obedient to what the prophets exhorted them to do, and returned to the worship of God. Now all these came running to Jerusalem, to Hezekiah, that they might worship God there. ${ }^{324}$

In context of the account as a whole (Ant. 9.258-274), the concluding clause, "that they might worship God there", refers to accepting the king's invitation to come to Jerusalem to

\footnotetext{
${ }^{321}$ There festival celebrates, of course, the memory of the original exodus, but a memorial is not the same as an enacted repentance or community reconstitution.

${ }^{322}$ For Josephus' retelling of the reforms and Passover under Hezekiah, see Ant. 9.258-274. On the Biblical sources used by Josephus, see Begg and Spilsbury, Antiquities, 195, and Colautti, Passover, 52-53, who conclude that 2 Chr. 30 is primary.

${ }^{323}$ Ant. 9.264. In Josephus, Passover is implied by reference to the feast of unleavened bread. See Ant. 9.271: "as the feast of unleavened bread was now come, when they had offered the sacrifice called the Passover, they after that offered other sacrifices for seven days."

${ }^{324}$ Ant. 9.267 .
} 
celebrate Passover. The "return to worship of God" and celebration of Passover in Jerusalem are not co-extensive, for the narrative ends with reference to the long-term commitment of the people (manifestly beyond Passover) to continue in the worship of God. ${ }^{325}$ Yet Passover functions as the inauguration of this renewed worship of God. Attendance at Passover, therefore, is tantamount to joining the king and all the people in "returning" to God. Josephus also expands the comment of $2 \mathrm{Chr} 30: 10$ which reports the rejection of the king's proclamation by some of the people and he devotes greater attention to the significance of the people's scorn and rejection of the royal ambassadors. ${ }^{326}$ His concluding remark (absent in the Biblical text), is most revealing: "God, as a punishment for their impiety, brought them under their enemies". Josephus forms a direct link between the punishment of exile and the people's refusal to heed the call to covenant renewal through celebration of the Passover. For Josephus, to participate in the Passover festival on this occasion was to signify and enact the restoration of the relationship of the community with God. Failure to attend represented a rejection of the covenantal relationship.

Josephus' account of the Passover under Josiah similarly emphasizes the connection between Passover and reconstitution of the community already found in the Biblical narrative. ${ }^{327}$ Twice Josephus makes explicit what is left implicit in the Biblical account, namely that Josiah's purgative program was fundamentally an effort to bring the people back into covenant relationship with the Lord. Josephus says of Josiah's destruction of idols throughout the country, "by this means he brought the people back from their opinion about them to the worship of God". ${ }^{328}$ Of those Israelites who had escaped Assyrian captivity and returned to the land, Josephus comments, "[Josiah] persuaded them to desist from their impious practices and to leave off the honors they paid to strange gods but to worship rightly their own Almighty God and adhere to him.." ${ }^{329}$ Josephus also highlights the covenant renewal ceremony whereby

\footnotetext{
${ }^{325}$ Cf. Ant. 9.273-274.

${ }^{326}$ Ant. 9.265-266. 2 Chr 30:10 reports simply, "the couriers went from city to city through the country of Ephraim and Manasseh, and as far as Zebulun, but they laughed them to scorn and mocked them." Perhaps drawing upon the account of northern recalcitrance in $2 \mathrm{Kgs}$ 17:13-14 (see Flavius Josephus, translation and commentary Christopher T. Begg and Paul Spilsbury, Judean Antiquities Books 8-10 (Flavius Josephus Translation and Commentary; Leiden: Brill, 2005), 196), Josephus expands as follows: "the Israelites, upon the coming of the ambassadors, and upon their laying before them what they had in charge from their own king, were so far from complying therewith, that they laughed the ambassadors to scorn, and mocked them as fools: as also they affronted the prophets who gave them the same exhortations, and foretold what they would suffer if they did not return to the worship of God, insomuch, that at length they caught them, and slew them; nor did this degree of transgressing suffice them, but they had more wicked contrivances than what have been described: nor did they stop before God, as a punishment for their impiety, brought them under their enemies: but of that, more hereafter" (Ant. 9.265-266).

${ }^{327}$ See Ant. 10.47-73. On the Biblical sources used by Josephus, see Begg and Spilsbury, Antiquities, 228, and Colautti, Passover, 59-61, who concludes that $2 \mathrm{Chr}$. 35 is primary.

${ }^{328}$ Ant. 10.53 .

${ }^{329}$ Ant. 10.68 .
} 
Josiah makes the people take an oath to worship God in accordance with the Law of Moses. ${ }^{330}$ The celebration of Passover, then, functions as the culmination (again, more explicitly than in the Biblical account) of all Josiah's efforts to restore the covenant community to a right relationship with God.

Unlike the account in $2 \mathrm{Chr} 35$ which makes no express mention of gathering the people together at Jerusalem for the feast, Josephus reports, "when he had thus cleansed all the country, he called the people to Jerusalem and there celebrated the feast of unleavened bread and that called Passover." ${ }^{331}$ Again, with even greater emphasis than the Biblical account, Josephus makes observance of Passover on this occasion constitutive of community membership.

Josephus may contribute further to the analysis of Passover beyond his retelling of the accounts above. Evidence throughout his work indicates that he attaches great importance to the annual celebration of the festival. Indeed, writing in the wake of the devastating war with Rome and the destruction of the Temple, Josephus evidently wished to portray the celebration of Passover as "one of the essential elements" in reconstituting Jewish identity. ${ }^{332}$ Thus, he downplays the importance of the centrality of the Temple for the celebration of the festival and of the priests and Levites for the sacrifices. ${ }^{333}$ This, of course, opens the way for the continuation of the festival in the absence of the Temple and its sacrificial system. In addition, Josephus presents the festival as inclusive of women and children (over against, for example, the custom at Qumran). ${ }^{334}$ This step, together with the one preceding, allows for the re-centering of the celebration around the family, a move which improves its chances of preservation in the post-70 era. ${ }^{335}$ On the other hand, Josephus underscores the importance

\footnotetext{
${ }^{330}$ Ant. 10.63-64.

${ }^{331}$ Ant. 10.70.

${ }^{332}$ The argument is that of Colautti and receives development across the entirety of his work on Passover. See, esp., Passover, 240.

${ }^{333}$ E.g., Ant. 10.70-72 (cf. 2 Chr 35:2-6, 10-12) where the implication seems to be that the people offered sacrifices apart from the Levites. See discussion in Colautti, Passover, 63, 65. Of course, the de-centering of the festival away from the Temple is also represented among diaspora Jews in the well-known passage from Philo Spec. 2.145-148 which describes individuals performing the sacrificial rites at their homes in direct parallel to the priests of the Temple.

${ }^{334}$ E.g., the expansion of the Biblical account in Ant. 11.109 (cf. Ezra 6:20).

${ }^{335}$ The family emphasis is evident, for example, in the mention of the family both where it is present and absent in the Biblical sources. See, for example, Ant. 2.312 (cf. Ex 12:3); 3.248 (cf. Lev 23:5; Num 28:16); cf. Colautti, Passover, 25, 36. Mishnaic handling of Passover in the post-70 period may exhibit a striking parallel to the thought of Josephus, here. Though the sacrifice of the lamb was central to Passover celebration throughout the second Temple period (see the survey of evidence in Baruch M. Bokser, The Origins of the Seder: The Passover Rite and Early Rabbinic Judaism (Berkeley: University of California Press, 1984), ch. 2), Mishnaic accounts of the pre-70 Passover celebration shift the emphasis from the sacrifice at the Temple to the private meal (seder), apparently in an effort to safeguard, in the post-Temple era, the continued observance of a feast believed to be crucial to community identity. Bokser argues that this anachronism is part of a widespread tendency in the Mishnah to re-interpret pre-70 cultic rites in such a way as to make continued observance possible in the post-70 period. In this way, "the Mishnah wants us to believe that the paschal sacrifice was important but not crucial, and that one could manage without the
} 
of proper observance by effectively denying the possibility of the "second Passover" as well as putting heightened emphasis on the purity of participants. ${ }^{336}$

I suggest, therefore, that although Josephus does not expressly invoke the legislation of Num 9:13 as does the author of Jubilees, yet the premium he places on participation in the first festival as well as his heightened concern for purity among all who attend closely approximate the outlook of Jub. 49. Passover, in the view of Josephus, was an occasion for re-establishing and strengthening "bonds of brotherhood among those that identified themselves openly with the politeia/politeuma of the Jews." 337 Participation in the festival was therefore of great importance for the renewed welfare both of the individual and of the community in the post-70 period.

\section{E.ii. John 6}

The evidence surveyed above locates the importance of Passover both in its annual observance as well as in its role in unique restorative events. On the one hand, the accounts of Passovers celebrated under Hezekiah, Josiah and Ezra formed an integral part of the restoration of the covenant community. These accounts (and their retellings in Josephus) indicate that failure to participate in the festival would have been tantamount to refusing to return to God and so become part of the newly reformed covenant people. On the other hand, Jub. 49 and the evidence of Josephus reveal an ongoing cognizance of the importance of participation in the annual festival for continued community membership. Thus, both in its role in unique restorative events as well as in the annual celebration, participation in the festival essentially sealed one's participation in the covenant community. ${ }^{338}$

These dimensions of Passover tradition form a very appropriate backdrop for the restorational theme that pervades John 6. I have argued that the summons to the eschatological meal (Isa 55) which caps the new exodus prophecies of Isa 40-55 exerted a decisive, shaping influence on both the language

sacrifice because other important elements remained viable nonetheless" (Bokser, Origins, 3). Bokser goes on to examine the redaction of $m$. Pes. 10 (Origins, ch. 4) He concludes, "the evidence repeatedly shows that the choice of subjects, wording and sequence of Mishnah Pesahim 10 as well as its location within the tractate can be effectively explained by a single proposition: the editor of the Mishnah desires to emphasize that the Passover celebration can and should continue even without the paschal lamb" ( Origins, 48). Thus, like Josephus, the Mishnah displays the conviction of the crucial importance of continued Passover observance, even if that observance must differ from pre-70 custom.

${ }^{336}$ For the suppression of the second Passover, see Josephus' contradiction of the Biblical witness at Ant. 3.294 (cf. Num 9:9-11) and 9.271 (cf. 2 Chr 30:2), and cf. Colautti, Passover, 53-67. Regarding purity, note the alterations to the Biblical sources at Ant. 2:312 (cf. Ex 12:7) and 11.109 (cf. Ezra 6:21//1 Esd 7:13) and see Colautti, Passover, 133-143 (esp. 139).

${ }^{337}$ Colautti, Passover, 240.

${ }^{338}$ Nielsen, "Lamb", 239, sums up the tradition in somewhat similar terms: "the fundamental motif...is transferral" from slavery to freedom, from death to life. I would add, "from outside the people of God to part of the covenant community." 
and concepts of the Bread of Life discourse. The importance of the Passover meal for membership in the renewed covenant-community fits quite well within this Isaianic framework.

On the one hand, the summons of Jesus to the confused and skeptical crowds (cf. 6:34, 41, 52, 60) amounts to a summons to a unique, eschatological pascal meal which constitutes one's relationship to Jesus and thereby to the restored community. It is a summons to conversion. ${ }^{339}$ This is appropriate in context of the summons to the estranged, exiled people of God of Isa 55:1-2. The prophet does not envision the continuation of the present relationship with God but the entrance into a restored state of fellowship. ${ }^{340}$

On the other hand, Jesus' language of eating and drinking, particularly in vv. 52-56, refers to a pattern of ongoing belief and fellowship with Jesus. As annual observance of Passover was requisite for continued membership among the people of God, so one must go on "eating and drinking" the flesh and blood of Jesus to continue among his restored people. ${ }^{341}$ The call of Jesus is not merely to entrance into his fellowship, but to abiding in his fellowship.

This reading of Passover in John 6 which focuses on the nature of the pascal meal as constitutive of membership in the restored covenant community finds support from the recent study of discipleship in John by Rekha Chennattu. Drawing on the covenantal terminology and categories of the Old Testament, she argues that Johannine discipleship is essentially covenantal in character. This comes through especially in John's combination of the terms "believe", "abide" and "follow" in various passages in which discipleship is in view. In her examination of the narratives about the first disciples in John 1 she concludes, "by inviting the disciples to abide in Jesus and in his words (cf. 4:40; 6:56; 8:31-32) and making it an integral part of the process of becoming a disciple of Jesus $(1: 35-51 ; 4: 4-42)$, the Fourth Evangelist presents discipleship in terms of an everlasting and abiding covenant relationship with God." 342 The idea that the language of "abiding" denotes covenant relationship receives greater elaboration in her treatment of the farewell discourse which she views as reflective "of an OT covenant

\footnotetext{
${ }^{339}$ Cf., for example, Dunn, "Eucharistic", 333, who concludes that John 6:35 "makes it clear that the 'eating' and 'drinking' is simply a vivid metaphor, highly appropriate in the circumstances, for coming to and believing in Jesus."

${ }^{340}$ Cf. esp. Isa 55:6-7, "Seek the LORD while he may be found; call upon him while he is near; let the wicked forsake his way, and the unrighteous man his thoughts; let him return to the LORD, that he may have compassion on him, and to our God, for he will abundantly pardon."

${ }^{341}$ It bears remembering that throughout John 6 the pascal symbolism has been combined with symbolism from the wilderness provisions of manna and quail, a provision made not once for all but on a daily basis. This, of course, is precisely the point of Deut 8:3-6 which interprets the manna provision in terms of the provision of the Law for the people as they entered the Promised Land: it is precisely the day-to-day observance of the Law which is necessary for continued life in the land.

${ }^{342}$ Johannine Discipleship as a Covenant Relationship (Peabody, MA: Hendrickson, 2006), 44.
} 
renewal form or genre." ${ }^{343}$ Though she never turns her attention to John 6, her work elsewhere in the Gospel goes a long way to establishing the essential covenantal nature of discipleship in the Gospel. Many of the elements which comprise this covenantal relationship are present in John 6 , chiefly, the call to abide in Christ (cf. 6:56).

Closely related to this line of interpretation is the work of Edward Malatesta on the language of abiding $\left(\mu \in v^{\prime} \in \nu\right)$ in Johannine literature. Malatesta looks at several passages in the Old Testament which he argues form the essential background to John's use of $\mu \in v^{\prime} \in \mathrm{L} \nu$. He contends that "the combination of mene, in and its cognates with the Covenant, the commandments, and with Yahweh himself, connotes a relationship of fidelity to and communion with Yahweh, and that such expressions prepare the Johannine use of the verb." ${ }^{344}$ Noting the precedents in the LXX for the idea of "remaining" in the commandments of God (Deut 27:26; Sir 28:6) and in God himself (Isa 30:18; cf. Sir 6:20 of wisdom), he

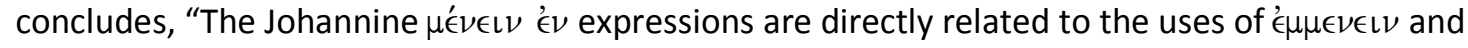
$\epsilon^{\prime} \mu \mu \in \nu \in L \nu \mathcal{G}^{\prime} \nu$ in the LXX. The contexts of the Johannine formulae are similar to those of the LXX: the Covenant, observance of the commandments, fraternal union, the merciful love of God." ${ }^{345}$

Thus, as in discipleship passages elsewhere in the Gospel (1:35-51; 14-16), the teaching about discipleship in John 6 employs language associated in the LXX with Israel's covenant relationship with God. The effect of this is to sharpen the covenantal nature the discipleship in view.

\section{F. Conclusion}

I have sought to establish that the predominant scholarly emphasis on the sacrifice of the pascal lamb in the Fourth Gospel's use of Passover symbolism has prevented most interpreters from discerning the author's main interest in this background. The essential message of John 6, the central Passover context in the Fourth Gospel, is that Jesus brings about the national restoration by means of his death as the Suffering Servant, but only those who avail themselves of this salvation through believing, abiding fellowship with Jesus may participate in the restoration. John has clothed these ideas in the imagery surrounding the pascal lamb: the lamb is sacrificed with a view toward supplying food for the pascal

\footnotetext{
${ }^{343}$ She continues, "The Evangelist programmatically organizes these chapters and gradually discloses a discipleship paradigm that manifests elements that parallel an OT covenant relationship" (Discipleship, 89).

344 Interiority and covenant: a study of 'einai en' and 'menein en' in the first letter of Saint John (Analecta Biblica. Rome: Biblical Institute Press, 1978), 60. One example is found in Deut 27:26 caps a list of twelve curses for specific breaches of the covenant relationship with a general curse for infidelity in general: "Cursed be anyone who

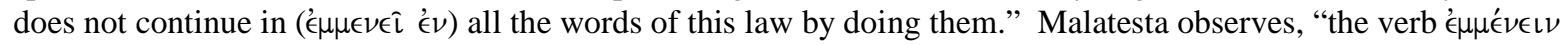
with oủx is used to express the root of all infidelity." He points, also, to Isa 30:18; Pss 5; 60; Jer 31:32 (the "most important" background text for John's usage; 63); Sir 6:20; 11:20-21; 28:6-7; Wis 7:27-28.

${ }^{345}$ Interiority, 64.
} 
meal, the eating of which is requisite both for entrance into and continued status within the redeemed community. Herein lies the significance of the sacrifice of Jesus as pascal victim: not atonement for sin but provision for the all-important pascal meal. Both in the Old Testament and in Jewish tradition participation in the festival was requisite for membership in the (restored) community. As Jesus effects the hoped-for Isaianic restoration of the nation he himself is the pascal lamb who must be eaten by all who would participate in the restored community of the people of God.

Finally, John's use of this festival is entirely consistent with his wider representation of Judaism as I argued for in the previous chapter. Jesus does not set aside Passover. Still less does he judge the institution or debase its associated customs. On the contrary, he represents his salvation as the fulfillment of the eschatological hopes associated with the festival, and participation in his salvation as contingent upon "eating the Passover" in its eschatological enactment. Jesus evokes the symbolism at the center of the festival (the pascal meal) in order to enter into it and clothe himself and his work in it. So far from urging his listeners to jettison this annual custom, he summons them to keep it in all its eschatological fullness (one is tempted to say, "in Spirit and truth"). For in Jesus are realized all of the highest aspirations of late-second Temple Passover festivals. 


\section{Chapter 4}

\section{The role of Tabernacles in John}

\section{A. Introduction}

In the previous chapter I examined the symbolism and traditions associated with Passover and how John appropriates them in his representation of the salvation Jesus brings. I argued that while he associates Jesus with the pascal victim destined for sacrifice, he lays the weight of emphasis upon the pascal meal centered around the eating of the sacrificed lamb. Observance of this custom, I argued, was constitutive of membership in the covenant community. John, then, signals that Jesus is the eschatological Passover lamb who must be eaten by those who would participate in the restored community of the people of God.

I turn now to the festival of Tabernacles, the second named festival of the Gospel. I will argue that the lines of thought evident in the Tabernacles section of the Fourth Gospel (John 7, in particular) run in parallel to those traced in John 6 in the previous chapter. Concerning John 6 I noted that John characterized the death of Jesus by combining exodus-wilderness traditions with the new exodus hope. By appropriation of Ps 78 (cited at John 6:31) and Isa 55 (alluded to a John 6:26-27 and throughout the discourse) the author recalled the manna tradition in order to show that the provision Jesus makes is analogous to the divine provision of food in the wilderness, though far superior inasmuch as it procures the eschatological life of the new exodus. John integrates the symbolism of the Passover festival to indicate that participation in this restored community comes about through the eating of the pascal lamb, Jesus Christ, soon to be given to death on the cross. Thus, John 6 interprets the cross of Jesus by reference to both exodus and new exodus traditions and refines this new exodus theology of the cross by application of specific facets of Passover symbolism. In the present chapter I will argue that John 7 evinces the same basic hermeneutical pattern. Appropriating, once again, Ps 78 and Isa 55 (as well as other eschatological prophecies) John develops his interpretation of the cross further by recourse to the festival of Tabernacles.

The origins of Tabernacles are traceable to the earliest days of Israel's history. ${ }^{346}$ The first mention of the Feast of Tabernacles comes in the "Book of the Covenant" in Exodus 23:16, where it is

\footnotetext{
${ }^{346}$ In what follows I will make a sketch of the Old Testament sources. For more detailed discussions see Karl William Weyde, The Appointed Festivals of YHWH: The Festival Calendar in Leviticus 23 and the Sukkôt Festival in Other Biblical Texts (Forschungen Zum Alten Testament 2. Reihe, 4. Tübingen: Mohr Siebeck, 2004), chs 6, 8-10;
} 
called the feast of Ingathering. ${ }^{347}$ The fuller account of Lev 23 describes a seven-day feast begun "on the fifteenth day of the seventh month" (Tishri) and characterized by offerings "made to the Lord by fire", and by "sacred assemblies" on the first and last days during which no work was to be done. ${ }^{348}$ The leading characteristics of the feast were the command to dwell in booths and "to take choice fruit from the trees, and palm fronds, leafy branches and poplars, and rejoice before the LORD your God for seven days." ${ }^{349}$ Though there is scant evidence of popular perceptions of the festival, Solomon's synchronization of the Temple dedication with Tabernacles (1 Kgs 8:2) as well as Jeroboam's appointment of a rival feast during the same season to minimize the attraction of the Jerusalem Temple on his northern subjects (1 Kgs 12:32) both indicate that the festival enjoyed great popularity among the people. ${ }^{350}$

In the earliest stages, the festival, and the booths in particular, expressly recalled the wilderness period of Israel's history (cf. Lev 23:42-43). ${ }^{351}$ Subsequently, during the post-exilic period, the festival assumed an eschatological orientation. The eschatological shape is clearest in Zechariah 14 where Tabernacles forms the backdrop for the worldwide pilgrimage to Jerusalem to worship and serve the God of Israel. Later Jewish tradition preserved both dimensions of this traditional background of the feast such that both the wilderness and eschatological backgrounds shaped the meaning and significance of various ceremonies as well as texts which describe them (I will return to this below). ${ }^{352}$

Håkan Ulfgard, The Story of Sukkot: The Setting, Shaping, and Sequel of the Biblical Feast of Tabernacles (Beiträge Zur Geschichte Der Biblischen Exegese, 34. Tübingen: Mohr, 1998), ch 4.1-4; Jeffrey Rubenstein, The History of Sukkot in the Second Temple and Rabbinic Periods (Atlanta, Georgia: Scholars Press, 1995), 13-20, 31-50; George W. MacRae, "Meaning and Evolution of the Feast of Tabernacles," CBQ 22 (1960) 251-276.

${ }^{347}$ The names of the feast in the Old Testament include, Feast of Tabernacles (Lev 23:33; Deut 16:13,16; Ezr 3:4; Zec 14:16,18,19); Feast of/to the Lord (Lev 23:39; Num 29:12); Feast of Ingathering (Ex 23:16; 34:22); The Feast (1 Ki 8:65; $2 \mathrm{Chr} 7: 8$ ); Feast that is in the seventh month (2 Chr 5:3; Neh 8:14); Feast in the month of Ethanim (the

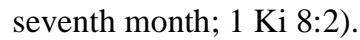

${ }^{348}$ Lev 23:33-43. See also Ex 23:16; 34:22; Num 29:12-38 (which enumerates the many sacrifices to be offered during the seven days of the feast); and Deut 16:13-15. Later reports of Tabernacles celebrations are found in $1 \mathrm{Kgs}$ 8:2; 12:32; Ezra 3:1-6; Neh 8:14-18.

${ }^{349}$ Lev 23:40

${ }^{350}$ Rubenstein, Sukkot, 19. The logic behind the dedication of the new altar during Tabernacles in Ezra 3:1-6 is probably best explained along the same lines as the dedication of the first Temple under Solomon.

${ }^{351}$ Weyde, Feasts, 157-159, building on the work of Frisch, "Exodus", has argued that the author of 1 Kings has shaped his account of Solomon's dedication of the Temple in such a way as to evoke the exodus and wilderness traditions. The author wished to lend legitimacy to the Temple by casting it as the culminating and consummating event of the exodus. If this is correct it would confirm the continued importance of the wilderness background for the meaning of the festival down through the period of the early monarchy.

${ }^{352}$ In Jesus' time, the main features of the festival were the dwelling in booths, the daily water and willow ceremonies and the nightly light ceremony. See the helpful summary schematic of the rituals and their days of observance during the festival week in David Instone Brewer, Feasts and Sabbaths: Sukkot (Traditions of the Rabbis from the Era of the New Testament 2b; Grand Rapids, Mich: Eerdmans, Forthcoming) 17. 
Scholarly treatment of this festival in John 7-8 typically focuses on the symbolic background of the water and light ceremonies in John 7:37-38 and 8:12, respectively. Representative of many commentators are the conclusions of Yee who summarizes, "[Jesus] is the new temple from which the 'rivers of living water' will flow", and in lieu of "the light of Tabernacles in the Jerusalem temple, Jesus becomes the "light of the world." ${ }^{353}$ That is, against the backdrop of the absence of the main ceremonies on the $8^{\text {th }}$ and final day of the festival Jesus declares that he is the true source of life-giving water and light. ${ }^{354}$

Much of the consensus regarding the backgrounds to the feast in the Mishna and Tosephta as well as the basic application of these backgrounds to John 7-8 is broadly correct. However, I believe the evidence invites further reflection, in particular, upon the background of John 7:37-38. Close scrutiny of the oft-neglected willow ceremony as well as the use of the Meribah tradition in $t$. Sukk. 3 may allow for greater precision in the interpretation of Jesus' words. In what follows, I wish to propose a reconstruction of the symbolism of the festival that leads to a more precise reading of John 7, a reading that takes more fully into account the mortal danger facing Jesus as he spoke, and that fits naturally with the emphases of the Gospel elsewhere. By way of anticipation, I will argue that Jesus' words in John 7:37-38 associate him specifically with the Temple altar which when struck will produce the lifegiving waters that must be drunk by those who would participate in the new exodus.

\section{B. Isa 55: Jesus as source of the eschatological waters of the new exodus}

\section{B.i. Allusion in John 7:32-37}

I begin by drawing attention to an oft-overlooked allusion to Isa 55 in John 7:32-37. ${ }^{355}$ In my treatment of Passover in John $6 \mathrm{I}$ followed the conclusion of Swancutt who argued in detail for the pervasive presence of Isa 55 behind the Bread of Life discourse. Among the indicators of this allusion were the verbal and thematic links surrounding the crowd's "seeking" and "finding" Jesus as well as

\footnotetext{
${ }^{353}$ Yee, Feasts, 82.

${ }^{354}$ A number of authors draw attention to the wider 'backdrop of absence' in the post-70 era. See Coloe, Dwells, 187 (cf. 130); Köstenberger, "Destruction”; V. Balabanski, “'Let anyone who is thirsty come to me': John 7:37-38 in dialogue with Josephus and the archaeology of aqueducts," LTJ 39 (2005) 139.

${ }^{355}$ Anthony Tyrrell Hanson, The Prophetic Gospel: A Study of John and the Old Testament (Edinburgh: T \& T Clark, 1991), 98, notes, "It seems probable that John has created the passage 7:32-36 largely out of a scriptural passage, Isaiah 55:5-6." Hanson, however, does not draw out the implications of the allusion for the flow of thought from vv.32-39. Cf. also J.C. Fenton, The Gospel according to John: In the Revised Standard Version, New Clarendon Bible. Oxford: Clarendon, 1970), 931; Hoskyns, John, 319 (also citing Deut 4:29; Hos 5:6).
} 
Jesus' invitation to come to him to eat and drink that which brings life. The same pattern of terms and themes is present in John 7, though evoking Isa 55 to different effect than in John $6 .^{356}$

The heart of Jesus' message to the crowds and leaders throughout John 5-10 can be summarized as an invitation to come to him for life (cf. 5:40; 6:35; 10:38). Jesus' climactic proclamation at the feast of Tabernacles in 7:37-38 represents a high point in this message and probably invokes Isa 55:1 for that purpose (see below). The context leading up to this great invitation records the search of

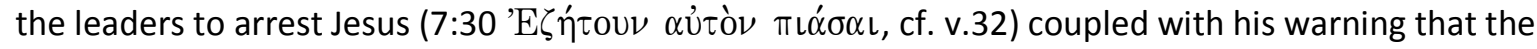
time for responding to his invitation grows short and that he will soon depart to "the one who sent" him. Against this setting, Jesus' words in 7:33-34 probably allude to Isa 55:6, albeit in ironic fashion:

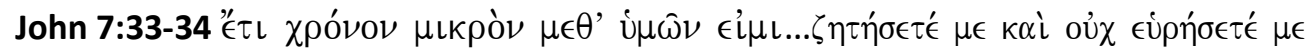

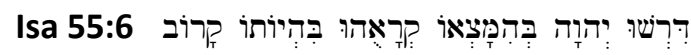

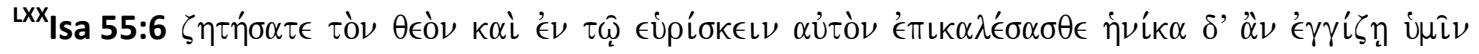

Isaiah urges the people to "seek God while he may be found". Jesus echoes these words in his response to the effort of the Jewish leaders to arrest him: "I will be with you a little longer, and then I

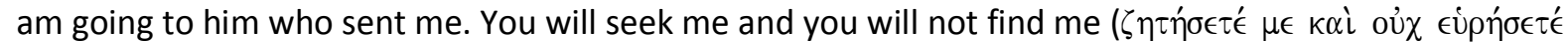
$\mu \epsilon)$. Where I am you cannot come." His words do not, of course, overlap perfectly: whereas the prophet exhorts (imperative $\zeta \eta \tau \eta \dot{\sigma} \sigma \tau \epsilon$ ), Jesus speaks predictively (indicative $\zeta \eta \tau \eta \dot{\sigma} \sigma \epsilon \epsilon) .{ }^{357}$ But these differences are attributable to John's need to mould the source text to fit the literary context in which the prophecy is put to ironic use (see further below). ${ }^{358}$

\footnotetext{
${ }^{356}$ This parallel between John 6 and 7 in the use of the exodus wilderness and new exodus traditions has been noted by Glasson, Moses, 48; G. Balfour, "The Jewishness of John's Use of the Scriptures in John 6:31 and 7:37-38," TynB 46 (1995) 377; Gary M. Burge, The Anointed Community: The Holy Spirit in the Johannine Tradition (Grand Rapids: Eerdmans, 1987), 91; Lincoln, John, 256.

${ }^{357}$ Hanson, Prophetic Gospel, 98, notes that the thought of John more nearly approximates the Hebrew than the LXX which mistranslates the original.

${ }^{358}$ So, similarly, M. Daise, “'If Anyone Thirsts, Let That One Come to Me and Drink':The Literary Texture of John 7:37b-38a," JBL 122 (2003) 689, with regard to 7:37. It is possible that Pro 1:28 also contributes to the allusive backdrop of John 7:32-37 (so Bernard, John, 279; Ridderbos, John, 271; Whitacre, John, 191; Günter Reim, Studien zum alttestamentlichen Hintergrund des Johannesevangeliums (Monograph series; Society for New Testament Studie; Cambridge: Cambridge University Press, 1974), 162). Proverbs 1:20-33 records the warning cry of Lady Wisdom to the simple to leave their foolish ways before it is too late; otherwise, "they will call upon me, but I will

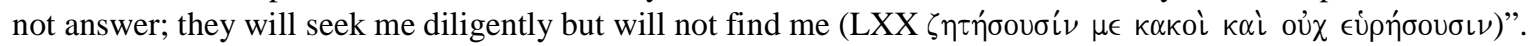
This possibility is strengthened by the evidence that John has made considerable use of the Wisdom/Sophia
} 
A more widely recognized allusion to Isa 55 comes in Jesus' climactic summons at John 7:37 to "come and drink". 359

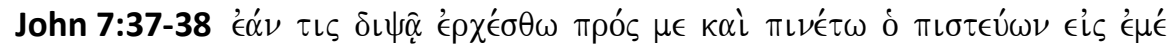

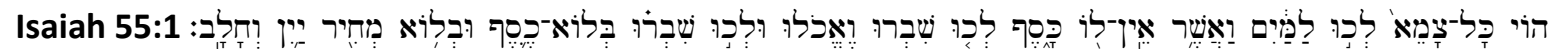

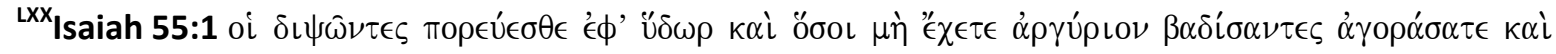

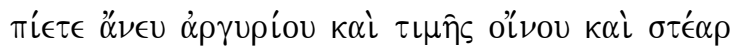

The presence of $\pi \iota \nu^{\prime} \tau \omega$ in John may suggest use of the LXX since the Hebrew lacks the verb for

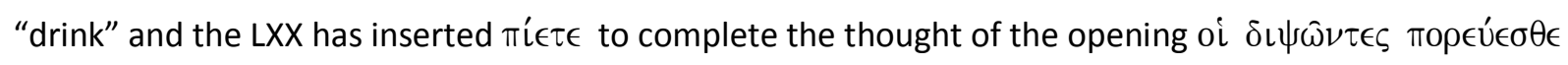
' $€$ ' Û $\delta \omega \rho$. Whether translating from the Hebrew independently or drawing from the LXX John has also

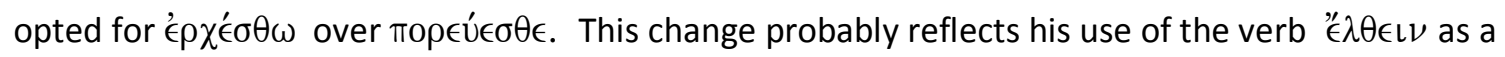
metaphor for faith in Jesus (cf. 3:20-21; 5:40; 6:35, 37, 44, 45), as well as a concern to forge a link with the preceding context where he twice warned of the approaching time when the Jews would not be able to "come" to where he is going $(7: 34,36){ }^{360}$

In addition to these allusions to Isa 55:1 and 6, the motif of Jesus' return to God (7:33) may also depend on Isa 55. Dahms, "Isa 55:11", has argued that Isa 55:10-11 forms an important part of the

traditions throughout the Tabernacles section (see esp. Catherine Cory, "Wisdom's Rescue: A New Reading of the Tabernacles Discourse (John 7:1-8:59)," JBL 116 (1997) 99-102; for John's use of wisdom traditions generally see Reim, Hintergrund, 193; also Witherington, John, 23, who claims this affinity for wisdom traditions accounts for the use of food and drink metaphors and forms one of the represents one of the most distinguishing features of John's style over against the Synoptics). Moreover, the subject кaкoi added in LXX Pr 1:28 complements Isa 55:6 in which the following context clarifies that it is "ungodly" and "lawless" people who are summoned in verse 6 (Isa

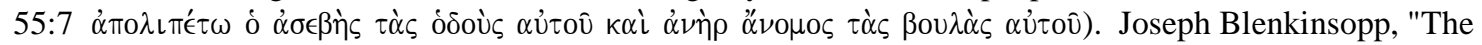
Quenching of Thirst: Reflections on the Utterance in the Temple, John 7:37-39," Scripture 12 (1960) 41-45, argues more broadly for the essentially sapiential form and content of Jesus' invitation, here and elsewhere in John (pointing especially to contexts such as Pro 5:15 and 9:4-5 [adduced already by Origen as background to John 7:38] where personified wisdom invites the thirsty to drink).

${ }^{359}$ Reim, Hintergrund, 193, noting a parallel use of Isa 55:1 in Sir 51:23, insists "es ist offensichtlich, dass sowohl die Einladung in Sirach als auch die im Johannesevangelium auf Jes 55,1 zurückgeht". See also Bruce, John, 181; Lindars, John, 298; Germain Bienaimé, “L'annonce des fleuves d'eau vive en Jean 7,37-39," RTL 21 (1990) 308; Marsh, John, 297; Whitacre, John, 193. Most simply note the allusion but supply no development of its significance for the passage. E.g., Carson, John, 322, calls it "probable" but seeks a "more focused significance" in the background of Neh 9 .

${ }^{360}$ Daise, "Thirsts”, 698-699. 
thematic background to the come from God / going to God motif throughout John, including at 7:32-36. If he is correct, this represents another parallel with the use of Isa 55 in John 6 as argued by Swancutt. ${ }^{361}$ This background of Isa 55 throughout John 7:32-38 is rich with ironic significance for John's narrative. Though the seeking-motif with reference to discipleship is common enough throughout the Gospel, ${ }^{362}$ the motif takes a dark turn in chapters 5-10 where the Jewish leaders begin "seeking Jesus to kill him" because of his work on the Sabbath and claim to be the Son of God. Throughout these chapters nearly every mention of seeking by someone other than Jesus refers to the Jews' search for Jesus to kill him. ${ }^{363}$ This motif reaches its climax in John 7-8 where the Jews redouble their mortal search for Jesus during the eight days of the festival. ${ }^{364}$

The flow of thought of Isa 55:1-7 closely parallels that of John 7:32-39: Yahweh invites the people to come to him for the waters of life (55:1-3), yet he warns that the invitation will not last forever (Isa 55:6). By evoking precisely these passages in John 7:32-37 Jesus effectively urges his adversaries to reconsider the purpose of their search. "Seek the LORD while he may be found; call upon him while he is near; let the wicked forsake his way, and the unrighteous man his thoughts; let him return to the LORD, that he may have compassion on him, and to our God, for he will abundantly pardon." The words of the prophet form an apt summary of the message of Jesus at the feast of Tabernacles, though where Isaiah summons the people to the Lord, Jesus summons the crowd to himself. ${ }^{365}$

\section{B.ii. Implication: Jesus is source, not believer}

This leads naturally to the primary significance of John's use of Isa 55, in this context, namely, its indication of the source of the life-giving water in view at John 7:38. The problems surrounding the punctuation and orientation of John 7:37-38 as well as the various solutions have been often surveyed and discussed and I will not review them here. ${ }^{366}$ It is sufficient to observe that an important facet of

\footnotetext{
${ }^{361}$ Swancutt, "Hungers", 227-228.

${ }^{362}$ E.g., Jesus' question to his first disciples, "what do you seek?" (1:39), finds an echo in his question to Mary, "whom do you seek?"(20:15). Cf., also, the well-meaning search of the crowds for Jesus in 6:24,26 and 11:56.

${ }^{363}$ Exceptions are the references to the crowds' benign search for Jesus in 6:24, 26.

${ }^{364}$ Sixteen out of thirty-four total occurrences of $\zeta^{\prime} \eta^{\prime} \tau \omega$ in the Gospel occur in these chapters. Of these, eleven refer to the search of the Jews for Jesus $(7: 1,11,19,20,25,30,34,36 ; 8: 21,37,40)$. Of the remainder $(7: 4,18 \mathrm{a}, \mathrm{b}$; $8: 54 \mathrm{a}, \mathrm{b})$ the subjects are God or Jesus or a generic reference.

${ }^{365}$ Similarly, Hoskyns, John, 319.

${ }^{366}$ See, for example, the succinct discussions in Wengst, Johannesevangelium, 400-401; Kerr, Temple, 131-137; Tricia Gates Brown, Spirit in the Writings of John: Johannine Pneumatology in Social-scientific Perspective (Journal for the Study of the New Testament Supplem; London: T \& T Clark, 2003), 155-158; Burge, Anointed, 8893. Those who punctuate with a full stop after "drink" include Lagrange, Jean, 214-215; Barrett, John, 326-327; Lindars, John, 299; Marsh, John, 341-342; Morris, John, 375; Freed, Quotations, 23-24; Carson, John, 321-326;
} 
the debate concerns whether Jesus or the believer is the source of water in view at 7:38. Those who argue for the believer often claim support for this reading from the supposed precedent for this notion in John 4:14. ${ }^{367}$ It is simply taken for granted that this passage designates the believer as a source of the living water. But this is not at all obvious. For "in John 4:14, the 'spring of water welling up to eternal life' is a spring within the believer, procuring for him eternal life, as the antithetic parallelism makes clear." ${ }^{368}$ Bienaimé surveys the arguments for a parallel with 4:14 and concludes,

...Jn 4,14 invoqué en faveur de cette interpretation n'est pas un paralléle adequate. La formulation est différent: une source jaillit à l'intérieur (Jn 4,14), des fleuves s'écoulent de l'intérieur (Jn 7,38). L'imagerie change aussi. D'une part, l'activité de la source intérieure se substitute à l'acte de boire $(4,14)$; d'une autre part, on ne cesse de boire, en continuité avec la foi

Ridderbos, John, 273; Köstenberger, John, 240; Coloe, Dwells, 126-127; Balabanski, “Thirsty”, 139; Jones, Symbol, 154-155; Balfour, "Use", 369-370; G. Fee, "Once more - John 7:37-39," ExpT 89 (1978) 116; J. Cortes, "Yet another look at Jn 7:37-38," CBQ 29 (1967) 75-84. Those who punctuate with a full stop after "believes in me", preserving the parallelism between imperatives, include Lagrange, 214-215; Dodd, Interpretation, 342; Bultmann, John, 303; Brown, John, 321-323; Sanders and Mastin, John, 213-214; Bruce, John, 181-182; Smith, John, 174; Schnackenburg, John, 2:214; Yee, Feasts, 79; Burge, Anointed, 88-93; Dietzfelbinger, Johannes, 226; Keener, John, 728-729; Lincoln, John, 255; Wengst, Johannesevangelium, 291; Beasley-Murray, John, 115; Haenchen, John, 2.17-18; Hoskyns, John, 321; Moloney, Signs, 86; Kerr, Temple, 237; Brown, Spirit, 158; Aileen Guilding, The Fourth Gospel and Jewish Worship: A Study of the Relation of St John's Gospel to the Ancient Jewish Lectionary System (Oxford: Clarendon Press, 1960), 106; G.D. Kilpatrick, “The Punctuation of John vii.37-38," JTS 11 (1960) 340-342; J. Danielou, "Le symbolisme de l'eau vive,” RSR 32 (1958) 338; Luc Devillers, La Saga de Siloé: Jésus et la fête des Tentes (Jean 7,1-10,21) (Paris: Cerf, 2005), 82-83. M.J.J. Menken, "The Origin of the Old Testament Quotation in John 7:38," NovT 38 (1996) 163-167, strikes a third course: he follows the first punctuation but nevertheless argues that Jesus, rather than the believer, is the source in view. Drawing on evidence from LXX and extra-Biblical Hellenistic Greek sources he argues that $\alpha$ ưoû in v.38 resumes the thought of the pendent nominative

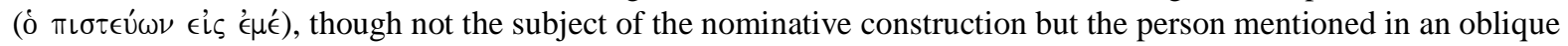
case, that is, 'є́' $\mu^{\prime}$, Jesus.

${ }^{367}$ See, for example, the citation of this text without further discussion in Freed, Quotations, 23; Fee, "Once More", 116; Sanders and Mastin, John, 213, 214; Marsh, John, 342; Cortes, "Another Look", 79; Balfour, "Use”, 374; Schenke, Johannes, 164; Wengst, Johannesevangelium, 291; Jones, Symbol, 155. Interestingly, Lagrange, Jean, 214-215, sees a connection with John 4 but views John 7 as making explicit what was evidently only implicit in the earlier context. He comments, "la parole de Jésus dépasse ce qu'il a dit á la Samaritaine (iv,10), parce qu'on voit mieux ici que l'eau vive que Jésus donners viendra de lui-méme comme d'une source." The same basic thought is articulated by Andreas Obermann, Die christologische Erfülling der Schrift im Johannesevangelium: eine Untersuchung zur johanneischen Hermeneutik anhand der Schriftzitate (Wissenschaftliche Untersuchungen zum Neuen Testament; Tübingen: J C B Mohr, 1996), 357.

${ }^{368}$ Menken, "Origin”, 165. So, also, Marie Emile Boismard, "De son ventre couleront des fleuves d'eau," $R B 65$ (1958) 535; Brown, John, 321; Wengst, Johannesevangelium, 401; Burge, Anointed, 90; Dietzfelbinger, Johannes, 226; Lincoln, John, 255; Whitacre, John, 193; Brown, Spirit, 157. See especially Um, Temple, 159-166, who shows that the background to John 4:10-14 in both the Old Testament prophets as well as contemporary Jewish tradition leads the reader to view Jesus as the eschatological, messianic source of the life-giving waters expected to flow from the Temple (see also Olsson, Structure, 216-218, and Ulfgard, Sukkot, 260-261). The term $\dot{\alpha} \lambda \lambda$ ou'́fou in 4:14 speaks of the inexhaustibility of this water (note the parallelism between $4: 14 \mathrm{a}$ and $\mathrm{b}$ ) rather than of the woman becoming a source for others. See further, on this, Lindars, 183-184. 
(7,37b-38a). La supposition d'un jaillissement intérieur destine au croyant perdrait sa raison d'être en Jn 7,38. ${ }^{369}$

Earlier in the Gospel, John emphasized the distinction between the water baptism of the Baptist and the Spirit baptism Jesus brings as Son of God by the three-fold, superfluous ' $\epsilon \nu$ ü $\delta \alpha \tau \iota$ culminating

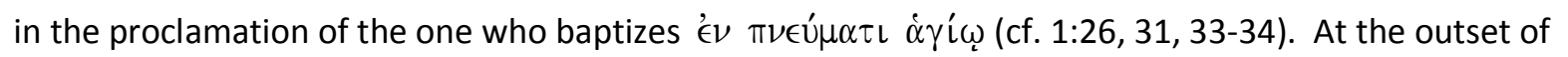
chapter 4 he extended this distinction to the disciples of Jesus: "Jesus was making and baptizing more disciples than John (although Jesus himself did not baptize, but only his disciples)" (4:1-2). The line of separation between Jesus and his disciples seems intended to preserve the emphasis on the Holy Spirit baptism that Jesus will uniquely provide. ${ }^{370}$ Thus, though the disciples play a role in the ministry of Jesus (4:37-38), their role is not co-extensive with that of Jesus. It is uniquely the role of Jesus to give the Holy Spirit.

This distinction continues in 20:21-23, another passage sometimes adduced by those who read 7:38 as referring to believers becoming a source of the Spirit for others. ${ }^{371}$ Jesus gives the Spirit to the disciples not that they might give it to others, for their ministry consists in the forgiveness of sins not the imparting of the Spirit. The Spirit, it seems, serves to illumine their understanding and empower their ministry (cf. 14:16-17, 26; 16:13). ${ }^{372}$ There is no support elsewhere in John, then, for the idea that believers become sources of the Holy Spirit themselves (even secondarily ${ }^{373}$ ). It would be surprising, then, if such were the case in John $7 .^{374}$

If appeal to other contexts (e.g., John 4:14) in support of making the believer the source of the water in 7:38 falters, the background of Isa 55 in the immediate context renders this view still less likely. The allusion to Isa 55 in John 7:32-37 casts Jesus in the role of Yahweh as the source of the life-giving water of the new exodus. ${ }^{375}$ The whole thrust of the context up to this point prepares the reader to

\footnotetext{
${ }^{369}$ Bienaimé, "L’annonce”, 303; cf. 293-294. Kerr, Temple, 237, reasons similarly.

${ }^{370}$ Keener, John, 587-588.

${ }^{371}$ E.g., Freed, Quotations, 24.

${ }^{372}$ For the place of the Spirit in the ministry of the disciples (including extended discussion of John 20:22), see esp. Burge, Anointed, 114-149, 198-221.

${ }^{373}$ Many who take this view make a qualification along the lines of Henry M. Knapp, "The Messianic Water that Gives Life to the World," HBT 19 (1997) 115: "This does not, of course, indicate that the believer is the origin of the water, but that the believer is mediately a source to others. The ultimate source remains...the Messiah.” Cf. esp. Z. Hodges, "Rivers of Living Water - John 7:37-39," BibSac 136 (1979) 242; Coloe, Dwells, 127.

${ }^{374}$ Reasoning along similar lines are Whitacre, John, 193; Kerr, Temple, 236-237; Wai-yee Ng, Water Symbolism in John: An Eschatalogical Interpretation (Studies in Biblical Literature; New York: Peter Lang, 2001), 80.

${ }^{375}$ So, also, Whitacre, John, 193.
} 
view Jesus as the source of the water that gives life, and neither in Isa 55 nor in John 7 is there anything to direct the reader to the idea of the believer becoming a source of this life-giving water. ${ }^{376}$

The pattern of thought in John 6 points in this same direction. There also I showed John interpreted the feast of Passover against Isa 55 and Ps 78 to indicate that Jesus, by his death, would provide the food that gives life. This idea of Jesus as source of that which gives life dominated the chapter as a whole (cf. my discussion of $6: 5,51$ ) and at no point does John give any indication that the disciples, too, will give life (again, even if secondarily). ${ }^{377}$ As Devillers observes, "les défenseurs de la lecture en fonction du croyant oublient de tenir compte du contexte précis dans lequel l'oracle de Jn 7,38 intervient: ...cet oracle doit être reçu avant tout comme une parole de révélation concernant un aspect essentiel de la personne de Jésus." ${ }^{\prime 378}$ The Isaianic shape of the thought in John 7:32-37, then, adds greater weight to the conclusion that Jesus, not the believer, is the source of life-giving water in view in 7:38.

Some make much of the supposed conflict inherent in a summons to "drink" directed to "the one who believes": if drinking is a metaphor for belief then the statement becomes redundant ("let the one who believes in me believe in me."). Bienaimé comments on this punctuation ("coupure B"), "quelle que soit sa qualité formelle, le parallélisme de la coupure B manque de sense, quand l'impératif pineto adresse au croyant une invitation a se désaltérer." ${ }^{379}$ However, this problem may be more apparent than real since the reading creates a kind of step-progression in which 'coming to Jesus' is figurative for discipleship (cf. John 1:39, 46-47). One might paraphrase, "if anyone thirsts let him come to me, and let the one who comes drink." Urging those who have "come" and "believed" to (further) belief is not at all "lacking in sense" (contra Bienaimé) but is quite consistent with the conception of

\footnotetext{
${ }^{376}$ So, similarly, Menken, "Origin”, 165; Ng, Symbolism, 80.

${ }^{377}$ John appears to create a motif around the idea of source with the term nó $\theta \in v$. In 2:9 the author states in suggestive fashion that the master of the banquet did not from where ( $\pi \theta^{\prime} \theta \in \nu$ ) the wine came. In context, the pregnant comment points to Jesus as the source of the wine for the eschatological banquet. In 3:8, playing on the double meaning of $\pi \nu \in \hat{\nu} \mu \alpha$, Jesus states that Nicodemus does not know "from where ( $\pi \dot{\theta} \theta \epsilon \nu$ ) the wind/Spirit comes or where it goes". In context, the emphasis is surely on where the Spirit goes, that is, how he affects people. But against the setting of John 1-7 with the interest in Jesus' activity of giving the Holy Spirit (cf. 1:33; 3:34; 4:10, 13 $14 ; 6: 63 ; 7: 39$ ) the first part of the statement ("you do not from where it comes") surely hints that what Nicodemus does not know is that the Spirit comes from Jesus. In 4:11, the woman asks Jesus, "from where (mó $\theta \in \nu$ ) will you get this living water?" While Jesus does not directly answer her question, it is clear that the source of this water is Jesus himself. In parallel fashion, the question of Jesus to Philip in 6:5 orients the following narrative (and discourse) around the idea that Jesus is the source of the food that brings life. Strikingly, the term nó $\theta \in v$ occurs seven times across the feast of Tabernacles, every time with reference to the knowledge of Jesus' origins (7:27 [2x], 28; 8:14 [2x]; 9:29, 30). The motif culminates with the unanswered question of Pilate to Jesus, mó $\theta \in v \in \hat{\imath}$ oú; (19:9). See further the discussion of Devillers, Siloé, 68-73.

${ }^{378}$ Devillers, Siloé, 82.

${ }^{379}$ Bienaimé, "L'annonce”, 286. Cf. Morris, John, 375; Cortes, “Another Look”, 81; Menken, “Origin”, 164.
} 
belief in the Fourth Gospel as a complex matter admitting of different levels of maturity. Jesus summons those who have believed in him on one level to deeper faith that will abide forever, as, for example, the summons to the believing crowds in John 6 to eat and drink his body and blood, metaphors signifying not a once-for-all faith-act but a perpetual, believing fellowship with the Son.

\section{Citation at John 7:38: Meribah and eschatological Temple backgrounds}

Recognizing the background of Isa 55 in John 7:32-37 clears the way to address the question of the citation in John 7:38. Commentators commonly discern a range of possible Scriptures behind John 7:38. ${ }^{380}$ These can be divided fairly neatly into two groups: those which locate the source of eschatological waters in the believer and those which locate the source in Christ. The first group, represented chiefly by Isaiah 12:3 and 58:11, may be ruled out since, as I have argued, the source of water in view is Jesus not the believer. The Scriptures commonly adduced for the second group may be divided into two broad traditions: those recalling the wilderness provision of water from the rock (Ps 78:16, 20; 104:41; Isa 48:21; Neh 9:15; behind all of which stand Ex 17:1-6 and Num 20:2-13) and those foreseeing the eschatological effusion of water from the Temple (Ezek 47:1-10; Joel 3:18) or Jerusalem (Zec 14:8). On textual grounds, Zec 14, Ezek 47, and Ps 78 have most likely all contributed to the present form of John 7:38.

Zechariah 14:8 is intrinsically likely since it expressly mentions Tabernacles, it contains the expression "living water", and it was associated with the festival in (possibly later) Jewish tradition, as evident in the lectionary haphtarah (b. Meg. 31a) as well as the description of the water ceremony in t.Sukk. 3.18. ${ }^{381}$ Ezekiel 47:1-10 is another likely background because of its association with the water ceremony in early rabbinic tradition (m.Shek. $6.3^{382}=$ m.Mid. 2.6) as well as the prominence of Ezekiel 36-37 and 47 for the water-Spirit symbolism throughout John's Gospel. ${ }^{383}$ Finally, a background in Psalm

\footnotetext{
${ }^{380}$ See the list of probable and possible background texts in Freed, Quotations, 21-23.

${ }^{381}$ Guilding, Worship, 94, 105. The following scholars argue for the primacy of Zec 14:8: Danielou, "Symbolisme", 343; Dodd, Interpretation, 350; Guilding, Worship, 105-106; Schnackenburg, John, 2.155; Balfour, "Use”, 374-378 (though allowing for other influences as well); A. M. Hunter, The Gospel According to John (The Cambridge Bible Commentery. Cambridge: Cambridge University Press, 1965), 84-85.

382 "And why was it called the Water gate? Because through it they brought in the flagon of water for the libation of the feast [of Tabernacles]. R. Eliezer b. Jacob says: Through it the waters trickle forth and hereafter they will issue out from under the threshold of the house." The tradition is cited and elaborated in t.Sukk. 3.3-9.

383 On this, see especially Manning, Echoes, 194-197, and Keener, John, 726, who believes, “The use of Ezekiel's new temple image is probably more significant for the fourth Gospel than has hitherto been realized." For the primacy of Ezek 47 see also Hodges, "Rivers", 244; Moloney, Signs, 87; and Um, Temple, 157, who reasons along lines similar to Keener.
} 
78:16, 20 (and perhaps 105:41 and Isa 48:21) has been championed by several scholars on the grounds of the shared language and imagery of "drinking" from "rivers of water" that "flow from" a rock. ${ }^{384}$

Most scholars conclude that the words of Jesus represent a midrashic blend of several sources (particularly Zec 14:8; Ez 47:1-10; Ps 78:16, 20). ${ }^{385}$ The primary traditions comprising the citation of John 7:38, then, recall the Meribah tradition of Exod 17 and the future effusion of water from the Temple or Jerusalem. ${ }^{386}$ This conclusion is consistent with the influence of Isa 55 in John 7:32-37. A prominent feature of the new exodus deliverance depicted throughout chapters $40-55$ is the provision of life-giving water which is portrayed as a renewed Meribah provision that floods and fructifies the wilderness. ${ }^{387}$ Nevertheless, despite the dual prominence of these traditional backgrounds, scholars have commonly given Zec 14 and Ezek 47 pride of place in formulating the message of Jesus. ${ }^{388}$ The result is to discern in Jesus' words no more than the signification that he is the Temple from which the eschatological waters will flow. But John has already drawn upon these Scriptures to make this very point in the account of Jesus' dialogue with the Samaritan woman. ${ }^{389}$ Moreover, the narrative and historical setting of Jesus' words indicate that he faced mortal danger from official opposition during this feast (cf. 7:1, 11, 25, 30,

\footnotetext{
${ }^{384}$ Esp. Menken, "Origin", 268-275, and Daly-Denton, David, 149-152; also, Pierre Grelot, "'De son ventre couleront des fleuves d'eau ' La citation scipturaire de Jean, VII, 38," RB 66 (1959) 370 (though he later modified his position; see "Jean VII,38: eau du rocher ou source du Temple," RB 70 (1963) 48); Brown, John, 322; Lincoln, John, 256. In addition to Ps 78, Sanders and Mastin, John, 214, and Daly-Denton, David, 152, note that Isa 48:21 shares the verbs $\delta i \psi \alpha v$ and $\pi$ ivelv as well as the future tense orientation in common with John 7:37-38 (cf. John's

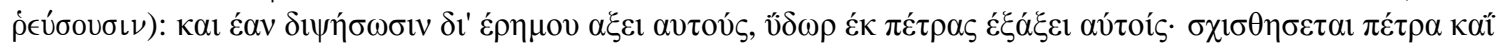

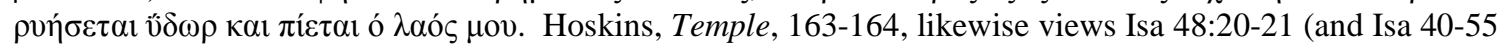
generally) as the key context behind John 7:38 anchoring the water imagery to the exodus/new exodus traditions, while Boismard, "Couleront", 544-545, regards John 7:38 as a conflation of Ps 78:16 with Isa 48:21-22, and Bienaimé, "L'annonce", 433-436, 441-443, argues for all three (Ps 78, 105; Isa 48).

${ }^{385}$ C.K. Barrett, "The Old Testament in the Fourth Gospel," JTS 48 (1947) 156: John "uses the Old Testament in a novel manner, collecting its sense rather than quoting." Cf. Hoskins, Temple, 164-165; Brown, John, 323; BeasleyMurray, John, 116; Yee, Feasts, 80; Freed, Quotations, 23, 37; Burge, Anointed, 92; Bienaimé, "L'Annonce" 431; Hanson, Prophetic, 113-4; Kerr, Temple, 241; Manning, Echoes, 195; Keener, John, 728; Lincoln, John, 256-257; Carson, John, 328; Whitacre, John, 196; Devillers, Siloé, 84-86; Brown, Spirit, 159-160.

${ }^{386}$ So, e.g., Grelot, “Jean VII, 38”, 47-51; Wengst, Johannesevangelium, 292; Dietzfelbinger, Johannes, 226; Thyen, Johannesevangelium, 403; Lincoln, John, 256; Hoskins, Temple, 163-166. The wilderness tradition is made clearer if a background in Neh 9 is granted. See Carson, John, 326-328, followed by Keener, John, 726. This background seems probable in view the Tabernacles setting of Neh 9 (cf. 8:13-18) as well as the express linkage between the gift of water and the gift of the Holy Spirit $(9: 13,15,20)$.

${ }^{387}$ Cf. Isa 43:20; 44:3. Andrew T. Lincoln, Truth on Trial: The Lawsuit Motif in the Fourth Gospel (Peabody, Massachusetts: Hendrickson, 2000), 53.

${ }^{388}$ An exception is Dietzfelbinger, Johannes, 226, who summarizes, "Da Priester und Volk um Wasser bitten, da man des wasserspendenden Felses aus der Wüstenzeit gedenkt (2.Mose 17,6; 4.Mose 20,7-11; 1.Kor. 10,4) und den Blick auf die in Ez. 47 verheißene eschatologische Wasserfülle richtet, tritt Jesus plötzlich vor die Menge und ruft: Das lebendige Wasser geht von mir aus: es verdankt sich nicht eurer Wasserspende. Was Mose einst tat, als er Wasser aus dem Felsen schlug (4.Mose 17,6: Ps. 78.16) - in mir ereignet es sich in eschatologischer Gültigkeit" (italics mine). Also noteworthy is Lincoln, Truth, 53, who insists that "the sequence of the Fourth Gospel's narrative provides a strong warrant for seeing Exod 17 and the Meribah incident as a major ingredient in the composite quotation [of 7:38]."

${ }^{389}$ See Um, Temple, 130-188, esp. 133-153.
} 
$32,44-52)$, that he raised the issue of his impending death both in veiled fashion $(7: 33-34 ; 8: 21-22,28)$ and expressly $(7: 19 ; 8: 40)$, and that the crowds finally sought to kill him themselves, forcing him to depart from the Temple and hide himself (8:59). The consensus reading of John 7:38 does not give due weight to this prominent element of the context. It may be that a corrective to this interpretation can be found in the thematic background of the Meribah tradition evoked by the citation of 7:38, the tradition that has too often been subordinated to the tradition of the eschatological Temple.

In what follows, I will argue that a fresh study of the main sources for the rituals surrounding the altar during the feast of Tabernacles suggests the possibility that Jesus' words may be understood with greater precision and in greater depth. Specifically, the festal background and narrative settings of his words identify him with the altar specifically, rather than the Temple generally, and hint that the flow of water results from the striking of this altar, that is, from his death.

\section{Analysis of $m$. Sukk. 4 and $t$. Sukk. 3: the altar ceremonies and the Meribah tradition}

\section{D.i. Water and Willow Ceremonies}

The basic features of the water ceremony in the late second Temple period are well known. Every morning of the festival a procession led by priests walked to the pool of Siloam, drew water with a ceremonial vessel, returned to the Temple amid blasts of the shofar and singing of the Hallel Psalms (Pss 113-118), and poured the water into one of two specially-made silver containers from which the water drained out through a spout and ran over the altar. ${ }^{390}$ This libation was carried out concurrently with the morning whole burnt offering and wine libation (which used the other silver container). ${ }^{391}$ The willow procession formed a popular ${ }^{392}$ part of the daily festivities of the feast of Tabernacles. ${ }^{393}$ Every day people would go out to a place called Motza to gather willow branches which they brought

\footnotetext{
${ }^{390}$ See m. Sukk. 4.9.

${ }^{391}$ T. Sukk. 3.16. For the daily wine libation see Ex 29:40; m. Zev. 6.2; and Jeffrey Rubenstein, "The Sukkot Wine Libation," in Ki Baruch Hu: Ancient Near Eastern, Biblical and Judaic Studes in Honor of Baruch A. Levine (eds. Robert Chazan, William W. Hallo and Lawrence H. Schiffman; Winona Lake: Eisenbrauns, 1999) 588-591. Scholars commonly argue that the basic purpose of the water ceremony was to procure rain for the coming year (citing esp. t. Sukk. 3.18; t. Rosh Hash 1.12; and the indication that Zec 14:16-17 was read on the $1^{\text {st }}$ day of the festival according to b.Meg. 31a). See R. Patai, "Control of Rain in Ancient Palestine," HUCA 14 (1939) 253-278; idem., Man and Temple in Ancient Jewish Myth and Ritual (New York: Ktav, 1967) 35-36; J. Petuchowski, “"Hoshi'ah na' in Psalm 118:25 - Prayer for Rain,” VT 5 (1955) 269-271; Jeffrey L. Rubenstein, "Sukkot, Eschatology and Zechariah 14," RB 103 (1996) 182-183; idem., Sukkot, 122-131; and MacRae, "Tabernacles", 269, 274, who adduces a remarkably similar Ugaritic ritual used for this express purpose. I will argue below, however, that the evidence of $t$. Sukk. 3 may justifiably be regarded as attesting an eschatological view of the ceremony in the pre-70 period.

392 The popularity of the ceremony no doubt arose from the inclusion of ordinary (i.e., non-priestly) pilgrims in the performance of the ritual, even inside of Temple precincts normally off limits to non-priests (cf. t.Sukk. 3.1). Brewer, Sukkot, 17, observes, "It is remarkable that the Willow Beating ceremony was allowed to occur on the last
} 
back to the Temple. They beat them against the sides of the altar before setting them upright such that the tops overhung the altar. ${ }^{394}$ After blowing the shofar three times, they marched around the altar once chanting Ps 118:25, "We beseech thee, O Lord, save us we pray! We beseech thee, O Lord, send to us prosperity." Another tradition reports that they chanted, "Ani waho, save us we pray! Ani waho, save us we pray!" On the seventh day they marched around the altar seven times. The ritual was performed on every day of the feast except the Sabbath (cf. m. Sukk. 4.1,3,4). ${ }^{395}$

Scholars commonly regard the willow ceremony, like the water ceremony, as a ritual aimed at procuring rain. ${ }^{396}$ "The willow, moreover, is a particularly apt symbol of the need for rain, since willows require copious amounts of water, and rapidly wither in times of drought." ${ }^{\prime 397}$ The branches, then, serve to accentuate the thirsty state of the earth. Moreover, both the willow and water ceremonies may have been associated with the mythic conception of the Temple altar as set upon the foundation stone (or as itself the foundation stone) at the center of the earth. The stone was believed to hold back the subterranean waters of chaos which were destined one day to burst forth and renew the face of the earth. ${ }^{398}$ Though traditionally believed to be a late development in Rabbinic thought, several scholars have recently argued for the pre-70 C.E. origin of this mythic view of the Temple altar. ${ }^{399}$ It is possible,

day, and this is probably an indication that too many people enjoyed taking part so it was impossible to stop it, even when the High Festival day was also a Sabbath (see t. Sukk. 3.1-2)." Cf. also, Rubenstein, Sukkot, 109, and literature cited.

${ }^{393}$ See description in m.Sukk. 4.5-6.

${ }^{394}$ That they beat the altar with the branches is evident from the verb חבתִ, 'to beat', used in $t$. Sukk. 3.1, and may be inferred from the riotous nature of the ceremony reported in $m$. Sukk. 4.5. Drawing together the scattered details of the various accounts, Brewer proposes, "Perhaps they made the willows 'bend over the top of the altar' by beating them against the side of the altar" (Sukkot, 22).

${ }^{395}$ For a helpful discussion and schematic of which rites were observed on which days of the feast and their relation 1to the Sabbath, see Brewer, Sukkot, 16-17.

${ }^{396}$ Patai, Temple, 34-35; Rubenstein, Sukkot, 117.

${ }^{397}$ Rubenstein, Sukkot, 117.

${ }^{398}$ Cf. t. Yoma 2.14// b. Yoma 54b // Pesiq. Rab Kah. 26.4; Tg Ps-J Ex 28:30; y. Sukk. 17.2, 29a; Pirqe Rab. El. 5; b. Sukk. 53a-b; and esp. b. Tan 25b. See additional sources and discussion in Keener, John, 729-730, and Rubenstein, Sukkot, 128-130.

${ }^{399}$ See Rubenstein, Sukkot, 122-131, and idem. "Sukkot," 183 and n. 104. The tradition undoubtedly has roots in the ancient Israelite view of the Temple (and altar) as a mountain and source of fertility (cf. esp. Ezek 28 and 47 which represents the Temple as a latter-day Garden of Eden, a mountain from which go forth life-giving streams to water the earth; see William Foxwell Albright, Archaeology and the Religion of Israel, Ayer Lectures of the ColgateRochester Divinity School, 1941 (Baltimore: The Johns Hopkins Press, 1953), 152; idem., "The Babylonian TempleTower and the Altar of Burnt-Offering," JBL 39 (1920) 137-142; Jon D. Levenson, "The Temple and the World," JR 64 (1984) 285; idem., Creation and the Persistence of Evil: The Jewish Drama of Divine Omnipotence (Mythos Series; Princeton: Princeton University Press, 1994), 92-93). In a detailed study of 4Q500 (a fragmentary text dated to the early $1^{\text {st }}$ century B.C.E. by Baillet [Qumrân Grotte 4 (DJD 7), xi-xiv]), Baumgarten has argued that the text represents a link in the chain of tradition running from the Old Testament through second Temple times into $2^{\text {nd }}$ century C.E. rabbinic sources. 4Q500, he argues, combines allusions to the vineyard passage of Isa 5:1-7 with Ezek 47:1-10 in a way which represents the temple as the "tower" in the midst of the "vineyard" (Jerusalem and its environs), and the altar as the "winepress" which is the source of fructifying waters for the "vineyard" (see Joseph 
therefore, that this mythic outlook was early enough to have contributed to popular conception of these festal ceremonies in the time of Jesus.

A number of lines of argument may be adduced in support of the early date of the traditions preserved in the Mishnaic witness. ${ }^{400}$ The description of Abraham's celebration of the festival in Jub. 16:29-31 closely resembles the ceremony described in the Mishnah and probably attests an early form of it dating to the second century B.C.E.. ${ }^{401}$ Moreover, Brewer has argued for the pre-70 origins of the ceremony by pointing to the ignorance of the location called Motza in later Rabbinic sources (cf. b. Sukk. 45a), and by highlighting the dispute with the Boethusians (t. Sukk. 3.1): "there was little point in finding new disputes concerning a group which no longer existed, and because the problem was solved in a rather ignoble way. ${ }^{402}$ Finally, Baumgarten has recently turned to recent discoveries from Qumran to augment the argument for the early date of the tradition preserved in $m$. Sukk. 4.5. Specifically, the use of the phrase אני והו as a substitute for the divine name found in the mishnaic record, though previously unattested in second Temple times, has recently come to light in a priestly blessing formula in 4Q266 (an early manuscript of the Damascus Document): "Blessed are you, אוב הו of everything, in your hands is everything, who makes everything." ${ }^{403}$ The willow ceremony described in $m$. Sukk. 4.5, therefore, seems likely to have been observed in the pre-70 period.

An additional ritual attested in the Mishnah ("the day of the beating of palm tufts") describes the bringing of palm branches which were then used to strike the altar. ${ }^{404}$ At the conclusion of the

M. Baumgarten , "4Q500 and the Ancient Conception of the Lord's Vineyard,” JJS 40 (1989) 1-6). 1 En. 89:50 may provide corroboration for this matrix of ideas if the identification of the Temple as a tower alludes to the vineyard tower of Isa 5 (Baumgarten , “4Q500”, 3). Further corroboration may be found in the popular attribution of fructifying powers to the residue of blood and water removed from the beneath the altar $(\mathrm{m}$. Yom. 5.6 reports that it was sold to local gardeners; cf. m. Mei.3.3). As he points out, this correlation of the imagery of Isa 5 and Ezek 47 with reference to the function of the altar and the libation offerings poured out upon it occurs also in $t$. Sukk. 3 suggesting the earliness of the tradition preserved in the Tosephta. (The study of Baumgarten receives elaboration and further corroboration from Qumran materials in G.J. Brooke, "4Q500 and the Use of Scripture in the Parable of the Vineyard," DSD 2 (1995) 268-279.) There seems to be good reason, therefore, for regarding this Rabbinic tradition as attesting a pre-70 view of the Temple altar.

${ }^{400}$ Rubenstein addresses at length the reliability of the Mishnaic and Tosephtan accounts of each of the ceremonies of Tabernacles. See Sukkot, 103-130, 152-161. Note also the careful discussion of dating in Brewer, Sukkot, 20-26. ${ }^{401}$ Cf. Rubenstein, Sukkot, 115-116.

402 Brewer, Sukkot, 23, 26.

${ }^{403}$ See Joseph M. Baumgarten, “A New Qumran Substitute for the Divine Name and Mishnah Sukkah 4.5," JQR 83 (1992) $1-5$.

${ }^{404}$ It is unclear whether this occurred on one day or every day. See m. Sukk. 4.6 and Rubenstein, Sukkot, 114-115, for discussion. T. Sukk. 3.1 suggests that the "beating with willow branches" was part of the willow procession. Whether the passage conflates the two traditions from $m$. Sukk. 4.5-6 or witnesses more accurately to the ritual as it was practiced is not clear. Rubenstein, Sukkot, 115, observes that there is no name given to the beating ceremony which takes place "on that day" as might be expected were it a distinct ceremony. This suggests that it was indeed part of the willow procession. That the branches were used to beat the altar itself rather than the ground may be inferred from the otherwise thoroughgoing altar-orientation of the ceremony. This is supported by the language in 
ceremony the people departed chanting, "Hommage to thee, O Altar! Hommage to thee, O Altar!" or, "To the Lord and thee, O Altar! To the Lord and thee, O Altar!" ${ }^{405}$ Little more is known of this ceremony though it is likely to have been more important than the brief mention in the Mishnah suggests. "It seems that numerous rituals were practiced over the course of the festival, only a few of which the Rabbinic sources preserve in detail. Besides the willow procession, palm branches (or willows) were gathered and struck against the altar, and other such rituals probably took place as well. ${ }^{406}$

\section{D.ii. Association of Jesus with the altar}

Against this ceremonial backdrop, many scholars perceive an allusion in John 7:38 to the waterlibation ceremony. The words of Jesus, uttered after seven days' observance of this rite and evoking the same scriptural backgrounds employed in later Rabbinic tradition, ${ }^{407}$ are taken to indicate that “L'effusion d'eau dans le Temple á la fête des Tabernacles est la figure de l'effusion eschatolgique de la vie divine. Et cette prophétie se realize quand le Christ, qui est le temple eschatologique, annonce á la Fête des Tabernacles que l'eau vive jaillit de son côté." ${ }^{\prime 08}$ Yet, I would suggest that the evidence may lead to the more precise conclusion that Jesus associates himself specifically with the altar, rather than the Temple in general.

In the first place, from the beginning of the second Temple period the festival was strongly associated with the Temple altar. For example, in Ezra 3:1-3, before the Temple had even been rebuilt, the festival was kept to celebrate the construction of the altar. This altar orientation is more poignant still in the etiology of the festival in Jub. 16 where Abraham celebrates the birth of Isaac (i.e., before the existence of the Temple!). References to the altar open and close the account $(16: 20,31)$ and recur throughout $(16: 21,22,23)$. The altar is central not only to the form of the narrative but also to daily

the terse account in $t$. Sukk. 3.1 which says the willows were "for the altar" and cites the chant of Eliezer in $m$.Sukk. 4.5, "for him and you, O Altar".

${ }^{405}$ The particulars as to how these rituals developed remain unknown. Leviticus 23:40 calls for celebration of the festival with "the fruit of trees...branches of trees... and willows of the brook." Second Maccabees 10:7 reports that the first Hanukkah, patterned after Tabernacles, entailed "bearing ivy-wreathed wands and beautiful branches and also fronds of palm, they offered hymns of thanksgiving to him who had given success to the purifying of his own holy place." Jubilees 16:31 reports that when Abraham celebrated the first festival of Tabernacles "he took the branches of palm trees and the fruit of good trees and every day going round the altar with the branches seven times in the morning he praised and gave thanks to God for all things in joy". Beyond the mention of carrying the branches while walking around the altar (Jubilees), none of these passages explains what more was done with them. ${ }^{406}$ Rubenstein, Sukkot, 115.

${ }^{407}$ See below my treatment of $t$. Sukk. 3.

${ }^{408}$ Danielou, "Symbolisme", 343; cf. also Yee, Feasts, 82; Coloe, Dwells, 133; Bruce H. Grigsby, "'If Any Man Thirsts': The Rabbinic Background of John 7:37-39,” Bib 67 (1986) 206. 
rituals that Abraham (supposedly) observed: "Abraham took branches of palm trees and fruit of good trees and each day of the days he used to go around the altar with branches" (16:31). ${ }^{409}$

The essential altar-orientation of the festival is also evident in the intensely popular water, willow and palm ceremonies I described above. The end-point of the water ceremony is the libation on the altar that occurs simultaneously with the wine libation (and the whole burnt offering). The great popularity of this final stage of the ceremony is conspicuous in the account of the pelting of priests who mishandled the rite (m.Sukk. 4.9). ${ }^{410}$ The willow ceremony also focused on the altar which was adorned with branches and circumambulated seven times by the priests calling out, "Homage to thee, O Altar! Homage to thee, O Altar" (m. Sukk. 4.5). The enigmatic ritual of beating the altar with palm branches also focuses specifically on the altar ( $m$. Sukk. 4.6). The prominence of the altar in these ceremonies may be heightened further if they are connected to (or perhaps enactments of) the mythic conceptualization of the altar that I described above. ${ }^{411}$ The aim of the ceremonies would, in this case, be to procure the waters of fertility from the sub-terranean stores beneath the altar by means of rituals performed upon and around the altar.

Thus, the earliest sources for Tabernacles observance in the second Temple period as well as the evidence of contemporary practice reveal that the festival was sufficiently altar-centered for Jesus' words to be regarded as referring to the altar rather than the Temple generally. This conclusion accords with the association of Jesus with the altar in the final festival before the Passion week, Hanukkah. ${ }^{412}$ In John 10:36, Jesus refers to his consecration and sending into the world by the Father. The saying is set against the backdrop of Hanukkah which celebrates the consecration and inauguration of the Temple altar by Judas Maccabeus following his defeat of the Seleucid forces and recapture of the Temple and Jerusalem. Scholars have commonly read Jesus' words with reference to the Temple generally such that he represents himself as the new locus of the divine dwelling among humanity. ${ }^{413}$ Drawing upon the historical context, however, Richard Bauckham has recently argued that the most likely reference at

\footnotetext{
${ }^{409}$ The altar also plays an important, though less pronounced, role in the celebration of Jacob in $J u b$. 32. For further discussion of the evidence of Jub. 16 and 32, see Ulfgard, Sukkot, 166-171; Rubenstein, Sukkot, 50-56.

${ }^{410}$ Here, again, helpful discussions about dating, historicity and identities surrounding the Boethusian incident in this passage may be found in Rubenstein, Sukkot, 110 n. 23, and Brewer, Sukkot, 25-26.

${ }^{411}$ For the possibility of a pre-70 date for this tradition, see my discussion above. Coloe, Dwells, 133, notes this background but wrongly, in my view, regards it as evidence for the centrality (merely) of the Temple. But the force of this tradition seems to be its narrowing of the focus of the ceremonies from the Temple generally to the altar specifically.

${ }^{412}$ I will devote the following chapter to extended consideration of this festival and its background.

${ }^{413}$ E.g., Coloe, Dwells, 153.
} 
10:36 is not to the Temple generally, but to "[Jesus'] consecration as the new altar of burnt offering." If this is correct, the reading I am proposing for John 7:38 would run parallel to and prepare for the altaridentification in 10:36. In these two strongly altar-centered festivals (Tabernacles and Hanukkah) John brings Jesus into association with the Temple altar. In the latter, set against the high point of official persecution of Jesus during his public ministry, he indicates that Jesus is "the eschatologically new altar on which the final sacrifice is to be offered, not yet but soon, within the narrative time of the Gospel."${ }^{415}$ In the former, also set against a high point in official pursuit of Jesus, he hints that Jesus is the Temple altar from which the life-giving streams will flow. ${ }^{416}$ Furthermore, and consistent with the emphasis of the Hanukkah account, the association of Jesus with the altar may point in the direction of a further conclusion, namely, that the means by which he would provide the life-giving water was his death. This conclusion represents Jesus' words as forming a more robust and fitting climax within a narrative setting fraught with the threat of death. It also takes fuller account of the Meribah tradition that contributes to the background of John 7:38, as well as the symbolism of the water and willow ceremonies that formed a regular part of the daily festivities. In what follows, I will explore this interpretation further by examining these sources of evidence in more detail.

\section{D.iii.1. Necessity of Jesus' death: evidence of the Meribah tradition}

I have argued that the Meribah tradition represents one of the two main traditional backgrounds behind the citation at John 7:38. A prominent feature of this tradition is the violent means by which the water is brought forth from the rock. The origin of the tradition, of course, depicts Moses striking ( $L X X \pi \alpha \tau \alpha \dot{\sigma} \sigma \sigma \omega)$ the rock with his staff (Ex 17:6; cf. Num 20:11). Subsequent references preserve this violent image by describing the action upon the rock as "striking" ( $\alpha \alpha \tau \alpha \dot{\alpha} \sigma \sigma \omega ;$ Ps 78:20), "tearing"

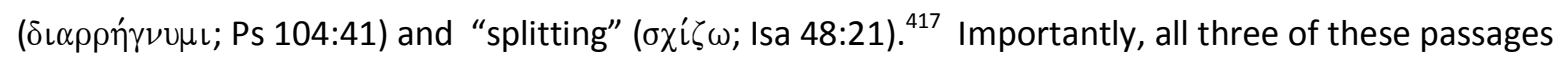
have been regarded as contributing to the textual shape of John 7:38. ${ }^{418}$ It seems appropriate, then,

\footnotetext{
${ }^{414}$ Richard Bauckham, "The Holiness of Jesus and his Disciples in the Gospel of John," in Testimony of the Beloved Disciple: Narrative, History and Theology in the Gospel of John (ed. Richard Bauckham; Grand Rapids: Baker Academic, 2007) 264.

${ }^{415}$ Bauckham, "Holiness", 264.

${ }^{416}$ Though Ezek 47 represents the streams as flowing from the Temple without reference to the altar, neither the general association with the Temple in Ezek nor with Jerusalem in Zec 14 necessarily preclude the more precise identification with the altar in Jesus' words. I will argue below that the way is opened for this more precise identification by the third textual background behind John 7:38, namely the Meribah tradition of Ps 78 and its use in t. Sukk. 3.

${ }^{417}$ Other passages thought to stand behind John 7:38 speak more vaguely of God "bringing forth" ( $\left.\xi \xi \eta \dot{\eta} \nu\right\} \kappa \alpha \varsigma$, Neh 9:15; ' $\xi^{\xi} \eta \dot{\gamma} \gamma \gamma \in \nu$, Ps 78:16) water from the rock.

${ }^{418}$ Again, see esp. Daly-Denton, David, 149-152.
} 
that greater weight should be given to this facet of the Meribah background than has commonly been done.

This suggestion finds support from the narrative setting (John 7-8) permeated, as I noted above, by a sense of mortal threat to Jesus' life. I commented earlier on the contribution of the 'seeking-motif' to this atmosphere of danger. I also highlighted the manifold references to the Jewish attempts to arrest and kill him. In addition to these features, the structuration of the narrative frames the scene of Jesus' climactic announcement in the Temple (7:37-39) by two reports of controversy about him instigated by the authorities $(7: 10-36,40-52)$ as well as by two notes about the attempt by the leaders to arrest him $(7: 30,32,44-48)$. Indeed, the entire Tabernacles narrative (that is, John 7-8) is similarly framed as it begins by noting the mortal danger that awaits Jesus in Jerusalem (7:1) and concludes with the attempted stoning of him (8:59). ${ }^{419}$ Unmistakably, death is in the air throughout these chapters, indeed more so than at any other point prior to the passion narrative. Within this literary context it would be perfectly natural for the declaration of Jesus on "the last and greatest day of the feast" to allude to his death as the means by which his gift of life comes. That is, Jesus may invoke the Meribah tradition in part to hint that he, like the rock, will soon be struck in order to provide the life-giving water for the people.

Beyond these literary considerations, however, rabbinic evidence for the symbolic import of the water and willow ceremonies may lend greater plausibility to my reading of Jesus' words in John 7:3738. I will therefore address these background sources and in the process arrive at two conclusions. First, the paradigm for the eschatological hope associated with the water ceremony is the original provision by God via the rock of Meribah, and this tradition brings God into direct association with the rock that was struck. Second, the evidence of the willow and palm ceremonies suggests that the violent element of the Meribah tradition (the striking of the rock) may be evoked or re-enacted in the striking of the altar. The presence of these two lines of thought in contemporary tradition renders more plausible the suggestion that by associating Jesus with the altar during this festival when the threat of death was everywhere present John implies that Jesus will be 'struck' to provide the promised water for the people.

\section{D.ii.2. Necessity of Jesus' death: the evidence of the water ceremony}

In this section I will attempt to argue that the divine provision from the rock of Meribah serves as the paradigm for the eschatological hope signified by the water ceremony, and that the Meribah

\footnotetext{
${ }^{419}$ Note Keener, John, 773, who believes the near-stoning of Moses in Ex 17:4 stands behind John 8:59. If he is correct, this adds weight to my proposal that John has correlated the threat of death throughout John 7-8 with Meribah tradition.
} 
tradition brings God into direct association with the rock that was struck. I will do this in two stages: first, by examining the structure of $t$. Sukk. 3 and the role played by 3.11-13 within the chapter; second, by looking more closely at the citation from Deut 2 and its role in the flow of thought across 3.11-13. Tosefta Sukkah 3.3-18, which treats the water ceremony, may be divided into three distinct sections. ${ }^{420}$ The first section ( $t$. Sukk. 3:1-10) addresses the nature and significance of the ceremonial waters against the backdrop of the eschatological expectation of several prophetic texts. The second section (t. Sukk. 3:11-13) elaborates this significance in terms of the paradigmatic provision of water from the rock. The third section (t. Sukk. 3.14-18) describes the manner, timing and significance of the actual libation, again with reference to the eschatological expectation of Zec 14:17-18. Parallels between the first two sections indicate that the interplay between the eschatological and wilderness traditions contributed to the shaping of popular conception of the water ceremony in the pre-70 period. ${ }^{421}$ Indeed, this idea is already suggested by the chiastic ordering of the whole chapter around the themes of eschatological water from the temple/Jerusalem in the first and third sections and the water from the wilderness rock in the central section.

The first of these sections, Tosefta Sukkah 3.3-10, explains the significance of the water ceremony by drawing upon a series of prophetic texts that share a common focus on the eschatological flow of water issuing from Jerusalem. ${ }^{422}$ Ezekiel 47 , cited first and most often, is clearly the primary tradition associated with the rite, with the other citations likely associated with it by shared imagery and terminology. These passages conjure several important associations from their respective contexts. For

\footnotetext{
${ }^{420}$ This passage has rarely been treated in any depth by interpreters of John 7 (though cf. Grelot, "Jean VII, 38," 4351; Grigsby, "Thirsts", 105-107; Bienaimé, "L'annonce", 428-430). What follows represents a more detailed examination of the text and leads to different conclusions than have formerly been put forth.

${ }^{421}$ E.g., both describe a stream of water that flows through a desert $(3.9,12)$ and grows exponentially into a great river $(3.3-7,13)$ that finally empties into the Great Sea $(3.9,13)$. Note, also, the mention in both sections of small boats floating on the river $(3.6-7,12)$.

${ }^{422}$ Ezek 47:1-12, Isa 33:21, Zec 13:1; 14:8. In what follows I proceed with the assumption that early Rabbinic interpretation (as represented in the Mishnah and Tosephta) typically cited Scripture in a way which was respectful of its original context, and even assumed the reader's familiarity with it. See the work of David Instone Brewer, Techniques and Assumptions in Jewish Exegesis before 70 CE, (Texte Und Studien Zum Antiken Judentum; Tübingen: Mohr, 1992), who argues at length against the long-standing scholarly portrayal of Rabbinic exegesis as paying little regard to the Scriptural contexts of passages cited. He summarizes his thesis in the foreword: "the predecessors of the rabbis before $70 \mathrm{CE}$ did not interpret Scripture out of context, did not look for any meaning in Scripture other than the plain sense, and did not change the text to fit their interpretation, though the later rabbis did all these things." He provides a helpful summary of the matter of Scriptural context at p. 167-169 (and cites the work of J. Manne \& I. Sonne, The Bible as Read and Preached in the Old Synagogue, 2 vols. [Cincinnati, OH: $1940,1966]$ which gives extended treatment to some of the conclusions espoused by Brewer). In particular, he comments on the seventh middah of Hillel ("meaning is learned from the context"), "Although this rule is rarely specifically mentioned, it is frequently implied. Many exegeses cannot be understood at all without reference to the context of the text which is quoted" (p.169).
} 
example, the stream of water is associated with healing of the creation ${ }^{423}$ and the cleansing of $\sin$ and forgiveness for the people of God. ${ }^{424}$ It is associated with the restoration of Jerusalem/Zion following the defeat of her oppressors, a restoration which culminates in permanent protection and peace for the city and its inhabitants. ${ }^{425} \mathrm{It}$ is associated, finally, with the kingship of God. ${ }^{426}$

Though $t$. Sukk. 3.3-10 may not invoke all of these associations, some are explicitly appropriated in the picture of the libation waters. ${ }^{427}$ For example, the waters are said to "heal the waters" (מימן לרפאות) of the Great Sea, the Sea of Tiberias and the Sea of Sodom (t. Sukk. 3.9). This phraseology is

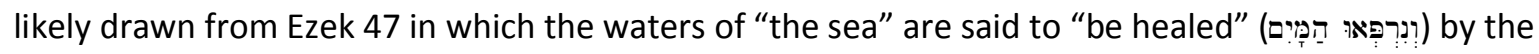
river flowing from the temple (Ezek 47:8, 9, 11). The Tosephtan account also parallels Ezekiel in its report that the healing qualities of the river impart life not only to the waters of the seas but to "every living creature which swarms" (t. Sukk. 3.9). The renovation of the creation may also be in view in the reference to the "waters from creation" that flow from the flask (3.10) as well as the reference to the water flowing down into the channels beneath the altar (3.14-15). These two passages (which frame the intervening wilderness material in 3.11-13) bring into close association Ezek 47 and Isa 5, both of which contribute to the mythic view of the altar which holds back the fructifying waters of chaos that flow beneath and are destined one day to flow forth and renew the creation (see discussion above). Finally, the context links the healing of the natural environment inspired by Ezek 47:7-12 with the purification from $\sin$ in Zec 13:1 (t. Sukk. 3.9). This first portion of t. Sukk. 3, then, associates the daily water ceremony with the prophetic hope of the renewal of creation and of the people of God by the flow of life-giving waters from the Temple and, perhaps, beneath the altar. ${ }^{428}$ Thus, the water ceremony was not merely a rain-making ritual; it carried eschatological associations, as well. After an extensive survey of the evidence for the association of Ezek 47 and Zec 14 with the water ceremony, Bienaimé concludes,

Dès une date ancienne, à la signification primitive de la fête des Tentes liée au rythme des saisons s'étaient ajoutées la commemoration du don de l'eau au desert et l'attente des eaux eschatologiques

\footnotetext{
${ }^{423}$ Ezek 47:7-12.

${ }^{424}$ Zec 13:1; cf. 12:7, 10. Cf. also the wider context of Isa 33:21 where the restored Jerusalem is revealed following the removal of the wicked $(33: 10-16,24)$.

${ }^{425}$ Isa 33:17-20; Zec 12:1-9; 13:1; 14:1-8, 11; Ezek 39:25-39 and 40:2 (for Zion as the mountain-city of Ezek 40-48, cf. Jon Douglas Levenson, Theology of the Program of Restoration of Ezekiel 40-48 (Harvard Semitic Monographs; Missoula, Mont: Scholars Press, 1976), 7-24).

${ }^{426}$ Isa 33:17, 22; Zec 14:9, 16.

${ }^{427}$ See, e.g., Germain Bienaimè, Moïse et le don de l'eau dans la tradition juive ancienne: targum et midrash, (Analecta biblica, no. 98. Rome: Biblical Institute Press, 1984), 212-214.

${ }^{428}$ See further on this, Bienaimè, Moïse, 221-222.
} 
jaillissant du Temple. Ces deux significations nouvelles remontent, selon toute vraisemblance, à une époque où la libation était encore pratiquée. ${ }^{429}$

The second part of the description of the water ceremony, t. Sukk. 3.11-13, notably departs from the eschatological Temple traditions in order to reflect on Israel's wilderness rock/well tradition as represented by Num 21:17-20, Ps 78:20, Ps 105:41, and Deut 2:7. The purpose of this second section is to set forth the past event as the model for the future hope. ${ }^{430}$ This is implied by the position of the section in the middle of the exposition of the eschatological texts in 3.3-10 and 14-18 as well as by the temporal shift between the sections. ${ }^{431}$ The paradigmatic function of Meribah for the eschatological provision is also suggested also by the express logical connector opening the second section (וכי, "and thus", 3.11).

Examining this central passage more closely reveals that, though never explicitly cited, the Meribah tradition of Exod 17:1-7 stands behind the thought of the whole. ${ }^{432}$ This is evident from the citation of Ps 78:20 (the same text that stands behind John 7:38) which refers to the scene in Exod 17. The Meribah tradition is correlated with Num 21:16-20, the account of the journey to Beer, "that is, to the well of which the Lord said to Moses, 'Gather the people together so that I may give them water.'” (Num 21:16). This context brings the well of Beer into close association with the rock of Meribah and so allows for the later identification of the two in Jewish tradition. ${ }^{433}$ Drawing from the song recorded in Num 21:17-18 and the brief itinerary immediately following, the Tosefta explains that this "well which was a rock" would encamp with the people, "on a high place opposite the Tent of Meeting" (3.11). The "Princes of Israel" would surround the rock, sing to it, then draw water with their staffs for their families and tribes. Clearly inspired by Pss 78:15-16, 20 and 105:41, ${ }^{434}$ the tradition explains that the rock, perched on its high place, gave forth such abundant water that it supplied not only the Israelite camp but the whole desert, as well (t. Sukk. 3.12). In a manner directly analogous to the description of the eschatological river of Ezek 47 in $t$. Sukk. 3.3-10, the waters from the rock grow exponentially before finally emptying into the "Great Sea" (3.13; cf. 3.9). Thus, the paradigmatic function of the Meribah provision for the eschatological hope evoked by the water ceremony is signaled by the position of 3.11-

\footnotetext{
${ }^{429}$ Bienaimé, Moïse, 229 (cf. 200-229).

${ }^{430}$ So, also, Grigsby, “Thirsts”, 107.

${ }^{431}$ T. Sukk. 3.3-10 is oriented toward the future as evident from the concluding statement: "This teaches that all the waters created at the Creation are destined (עתידין) to go forth from the mouth of this little flask." T. Sukk. 3.11-13 shifts the focus to the past: "And thus the well which was with Israel in the wilderness was (היתה) a rock."

${ }^{432}$ This is also the view of Yee, Feasts, 75; Grigsby, "Thirsts", 107.

${ }^{433}$ On this, see further below.

${ }^{434}$ Bienaimè, Moïse, 78-81.
} 
13 within 3.3-10 and 14-18 as well as by the concomitant temporal shift from future to past; and by the parallel descriptions of the flowing waters from the Temple and the well .

It remains to show that this tradition brings God into direct association with the rock of Meribah which supplied the people with water. The final citation of the central section of $t$. Sukk. 3 (Deut 2:7 cited in 3.13) is noteworthy because it is the one citation in 3.3-13 which makes no express reference to water. Deuteronomy 2:7 declares, "For the LORD your God has blessed you in all the work of your hands. He knows your going through this great wilderness. These forty years the LORD your God has been with you. You have lacked nothing." In the context of Deut 2 the statement follows the Lord's instruction to Moses to depart from the "mountain country" in which the people had been made to wander forty years, and begin heading north toward Canaan (Deut 2:2-3). The people were to pass through the territory of the descendents of Esau and they were given strict instructions to pay for everything they consumed, for it was not God's intention that they battle "their brothers" and take possession of their land (Deut 2:4-6). It is at here that God reminds the people that he has been ever present with them providing for their every need throughout the years in the wilderness.

It is remarkable that the Tosefta cites this verse because no express mention of the water of Meribah is made. The emphasis, rather, is upon the faithful presence of the Lord with his people during their time of need which was manifest in his blessing and provision for them. This focus on God represents a somewhat unexpected shift since the entire context leading up to the quotation in 3.13 focuses upon the persistent presence of the rock with Israel (or the well "which was a rock"). Fully four times in the introductory lines of 3.11 the text specifies that the well was "with Israel/them" (עם ישראל/ (עמהן throughout their journey. This idea of presence is central to Deut 2:7, though not the presence of the rock but of God himself: "he knows your going through this great wilderness; these forty years the

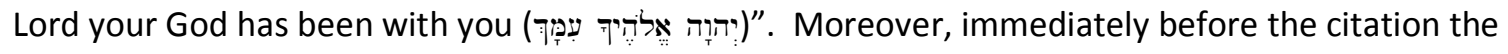
Tosephta reads, "So the water which flows forth from it is made into a great river and flows into the Great Sea. And they derive from it all necessary goods." "It", here, (Heb משט ) clearly refers to the rock as indicated by the citations from Pss 78:20 and 105:41 in the same context. Yet, with the citation of Deut 2:7 that immediately follows, the subject shifts from the rock to "the Lord your God." This stark shift heightens the close association of God with the rock. Clearly, then, the Rabbis interpreted the provision in Deut 2:7 as referring to the rock. Yet, the motif of presence with the people (presence of the rock in 3.11 and of God in 3.13) forms a frame around the section as a whole and suggests the 
association of God with the rock as the source of the waters which sustained the people in their wilderness journey.

This association of God with the rock is bolstered by the practice in later Biblical tradition of designating God as "the Rock". ${ }^{435}$ Deuteronomy 32:4 declares, "The Rock, his work is perfect, for all his ways are justice. A God of faithfulness and without iniquity, just and upright is he." ${ }^{\prime 36}$ Of particular note is the use of the epithet by the Psalmist in contexts which expressly recall the Meribah incident. Psalm 78:35, for example, states, "They remembered that God was their rock, the Most High God their redeemer", and Ps 95:1 opens, "Oh come, let us sing to the LORD; let us make a joyful noise to the rock of our salvation!" ${ }^{437}$ Isaiah 40-55 also appropriates the title in a setting which seems clearly intended to evoke the memory of Meribah. For example, Isa 43:1-44:8 depicts the redemption of Israel as a new exodus complete with a new provision of water in the wilderness, water ultimately identified with the Spirit of God (43:19-20; 44:3). The passage culminates with the asseveration, "Fear not, nor be afraid; ...you are my witnesses! Is there a God besides me? There is no Rock; I know not any (44:8)."

Closer in time to the Tosefta, 1 Cor 10:4 says of the wilderness generation, "they drank from the spiritual Rock that followed them, and the Rock was Christ." Paul's equation of Jesus with the rock represents a re-working of the belief that the rock of Meribah or well of Num 21 followed the people throughout their wilderness sojourn. This belief is widely attested in Rabbinic sources where the well is described as "rock-shaped like a kind of bee-hive, and wherever they journeyed it rolled along and came with them." ${ }^{438}$ Although these sources are demonstrably late, Brewer perceptively observes that a comment on this tradition in $b$. Pes. 54 a by the $2^{\text {nd }}$-century C.E. Rabbi Nehemiah appears to indicate "that it was already traditional by then" and so likely originated before the $2^{\text {nd }}$-century. ${ }^{439}$ Moreover, the $1^{\text {st }}$-century C.E. work Pseudo-Philo displays familiarity with the tradition when it says of the water of Marah, "it followed them in the wilderness forty years and went up to the mountain with them and went down into the plains." ${ }^{\prime 40}$ This text is especially valuable for the purpose of this chapter since, as Daly-Denton has argued, it suggests "Pseudo-Philo was in contact with a tradition which identified the waters of the desert rock with the waters flowing from under the Temple rock down to the plains in life-

\footnotetext{
${ }^{435}$ Reasoning similarly are Daly-Denton, David, 159; Lincoln, John, 257, and idem., Truth, 52.

${ }^{436}$ Cf. Deut 32:13, 15, 18, 30, 31, 37.

${ }^{437}$ Reference is made to Meribah at Ps 78:15-20, and 95:8-9. See Ps 18:1, 46 (=2 Sam 22:2, 47) for noteworthy uses of the epithet in the Psalter without express reference to Meribah.

${ }^{438}$ Num Rab. 1.2. Cf. Tg. Neof. Num 21:19; Tg. Ps.-J. Num 21:19; Tg. Onq. Num 21:19. For a reconstruction of the rabbinic tradition see esp. E. Earle Ellis, Paul's Use of the Old Testament, (Edinburgh: Oliver and Boyd, 1957), 6667. For further discussion of the sources and development of the tradition see Olsson, Structure, 162-173, and esp. Bienaimé, Moïse, 200-229.

${ }_{439}$ Brewer, Sukkot, 32 n.16.

${ }^{440}$ L.A.B. $11: 15$; cf. also $10: 7 ; 20: 8$.
} 
giving streams (Ezek 47:1-12; Zech 14:8-10)." She concludes, "L.A.B. has therefore preserved important first century CE evidence for the assimilation of the desert rock to the rock of Sion, and to its interpretation in light of passages which, as we have already seen, were particularly associated with Tabernacles." ${ }^{\prime 41}$ In other words, the thematic linkage between the Meribah tradition and the tradition of the eschatological water from the Temple that I have been examining in t. Sukk. 3 has attestation from at least as early as the time of John in the late $1^{\text {st }}$-century. Paul's use of movable rock/well tradition lends corroboration to the evidence of Pseudo-Philo for the tradition's currency in the first century. ${ }^{442}$ More than this, however, Paul associates the rock with Jesus and so gives evidence of the early Christian connection between Jesus and the rock of Meribah along lines similar to what I am proposing for John 7:38.

The association of God with the rock in t. Sukk. 3 assumes greater significance for the present discussion in light of the prominent role of the staffs of the princes in bringing forth water from the rock for their tribes and families. Mention of the staffs occurs twice in editorial summaries: "the princes of Israel go and surround it with their staffs and say to it the song in the wilderness concerning it, 'spring up, O Well, speak to it!' And each one draws with his staffs for his tribe and for his family, as it is said there, 'the well which the princes dug'.",443

Mention of the staffs outside the citations from Numbers suggests their inclusion held some importance to the editor. The importance is further evident from the second mention of the staffs which makes them the instruments for drawing water. This is a departure from Num 21, of course, where the staffs are only used for digging the well. The significance of this is clear when one recalls the scene of the original water provision in Exod 17:5-6 where the staff of Moses is instrumental in procuring water from the rock.

Also noteworthy, t. Sukk. 3.11 specifies that the "princes of Israel surround [the well]", a detail absent from Num 21:17-18. While it could perhaps be reasoned that the Tosephta simply makes explicit what is implied in the Numbers account, this conclusion does not settle well since it is the whole community that is "gathered" to the well and the princes are simply said to have dug it. The image of the leaders "surrounding" the well is probably more naturally explained by reference to Exod 17:5-6

\footnotetext{
${ }^{441}$ Daly-Denton, David, 156 (cf. 155-161). Westcott, John, 1.277, believes such is already implicit in Ezek 47 and Joel 3:18.

${ }^{442}$ On this text, and the moveable well tradition behind it, see Bienaimé, Moïse, 276-278; Anthony Tyrell Hanson, Jesus Christ in the Old Testament (London: SPCK, 1965), 16-23; Ellis, Use, 66-70; and esp. Anthony C. Thiselton, The First Epistle to the Corinthians: A Commentary on the Greek Text, The New International Greek Testament Commentary (Grand Rapids, Mich: Eerdmans, 2000) 727-730.

${ }^{443}$ In each case, the term for "staff" in the Tosephta (מקל) differs from the terms used in the Num 21:18 (מקחקרק and

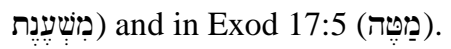


where the elders of Israel (in clear distinction from the people) are expressly made to stand by the rock as Moses strikes it. It appears, then, that the scene in Exod 17:5-6 has influenced the depiction of the scene from Num 21:16-20 in t. Sukk. 3.11-12. In both, the leaders of the community gather at the rock and water is brought forth for all the people by the instrumentality of a staff(s). ${ }^{444}$

Evidently, then, t. Sukk. 3.11-13 associates Yahweh with the rock which provided water for the Israelites throughout their wilderness wanderings and (under the influence of Exod 17:5-6) enlarges the role of the staffs of the princes in the procuring of the water (though the text stops short of speaking expressly of striking God). The water procured by the instrumentality of the staffs issued, in some sense, directly from the Lord himself.

\section{c.iii.3. Necessity of Jesus' death: the evidence of the willow ceremony}

I have been developing the argument that the words of Jesus at the climax of the festival of Tabernacles may associate him with the Temple altar and hint that, like rock in the wilderness, he will be 'struck' to provide the promised water for the people. In the previous section I tried to show how the exposition of the water ceremony in $t$. Sukk. 3 links the eschatological hope of Ezek 47 with the Meribah tradition of Exod 17. Moreover, this tradition seemed to hint at an association between God and the rock that was struck. In the present section I will round out the argument for my interpretation of John 7 by proposing that the Mishnaic evidence for the willow and palm ceremonies suggests that the violent element of the Meribah tradition (the striking of the rock) is symbolically present, perhaps even reenacted, in the festival by the ritual of striking the altar.

Typically commentators treating John 7:38 accord little or no attention to the willow procession. This may well be a mistake, however, for like the water ceremony the symbolism of the ritual contributes to the thematic import of Jesus' words. No explicit explanation is given as to the relationship between the willow/palm ceremony(s) and the water ceremony in any extant sources. Nothing is mentioned, for instance, about the relative priority of the rituals in the course of each day's events. Notwithstanding this, details in their respective accounts point to the likelihood of the interrelatedness of the two rituals.

To begin with, the depiction in t.Sukk. 3.11 of the scene in Num 21:17 bears important resemblance to the willow ceremony recounted in m.Sukk. 4.5. In t.Sukk. 3.11, the princes of Israel surround the well with their staffs, sing to it and draw water with their staffs for the blessing of their

\footnotetext{
${ }^{444}$ This conflation of the two scenes is also evident from the use of Pss 78:20 and 105:41 (both of which clearly refer to Exod 17) in the exposition of Num 21:16-20 in t. Sukk. 3.12.
} 
families and tribes. ${ }^{445}$ In similar fashion, during the willow ceremony the people march around the altar with the willow/palm branches (encircling it seven times on the seventh day), sing to it and beat it in hopes of bringing forth the needed rains for the land. Even the songs themselves bear some resemblance: where the princes of Num 21:17 sing, "Spring up, o well! Sing to it!", ${ }^{446}$ the people processing around the alter sing, "Save us, we beseech thee, O Lord! We beseech thee, O Lord, send now prosperity". ${ }^{447}$ An alternate tradition adds that when the people leave they addressed the altar directly, "Strength to you, O Altar! Strength to you, O Altar!" The songs sung by the people, then, though not identical, are similar in form, and in the case of one tradition for the willow procession are directed, respectively, to the well and altar rather than simply to the Lord. Finally, the two songs share a common purpose: to procure deliverance through the provision of water for the community. ${ }^{448}$ In this way, the willow ceremony begins to resemble a latter day re-enactment of the wilderness ritual represented in Num 21:17-18 (and elaborated in t. Sukk. 3.11).

Another indication of the connectedness of the rock/well tradition in Num 21:17 and the willow procession is the association of both the rock (in the former) and the altar (in the latter) with God. I argued above that $t$. Sukk. 3.11-13 associates the rock of Meribah with the Lord himself. In the willow procession, an association between the altar and God seems to be implied in the combination of activity centering around the altar and prayer and praise oriented alternatively to God and the altar. As the people march around the altar they pray to Yahweh and, as they depart, they chant, "Homage to thee, $\mathrm{O}$ Altar" or, "To the Lord and to thee, O Altar." This intertwining of orientations (altar-God-altar-God) strengthens the association between God and the altar I have argued for above.

\section{E. John 7}

The foregoing analysis suggests that it is reasonable to conclude, with due caution, that whatever the precise chronological or logistical relationship between the two ceremonies, the willow procession and water libation were closely linked both in concept and in imagery. ${ }^{449}$ The altar was not

\footnotetext{
${ }^{445}$ Mention of surrounding (וסובבין), as I noted above, is absent from Num 21:17-18 and probably comes from Ex 17:5-6.

${ }^{446}$ T. Sukk. 3.11 .

${ }^{447}$ M. Sukk. 4.5 quoting Ps 118:25.

${ }^{448}$ Cf. t. Sukk. 3.13. One might object that whereas the song of Num 21:17 is directed toward the well of the wilderness, the willow procession is oriented toward the Temple altar. But the song of Num 21:17 is recounted within a wider discussion of the water ceremony ( $t$. Sukk. 3.3-18) which revolves around the Temple altar. Once again, $t$.Sukk. 3 brings the wilderness and eschatological traditions into close association such that the former elucidates the latter.

${ }^{449}$ Rubenstein, Sukkot, 130-131, also believes the two ceremonies shared a common purpose based on the mythic view of the Temple altar discussed above.
} 
simply sung to and processed around, it was repeatedly struck by willow and/or palm branches as part of the daily rituals. This is especially suggestive in light of the correlation between the wilderness and eschatological traditions according to t.Sukk. 3. It may be that the altar came to represent a kind of latter-day rock of Meribah which was struck (in addition to being encircled by the people and overhung with branches) in order to procure water. Though this conclusion cannot be considered certain, the evidence I have examined suggests a reasonable degree of likelihood.

This reconstruction of the symbolism of the water, willow and palm rituals cannot, of course, be proven and so must be utilized with caution. As a possible reading of the background it illumines additional aspects of Jesus' words on the "last and greatest day of the festival" in John 7:37-38. Beyond a general reference to the Temple as the source of the flow of eschatological waters, Jesus may well associate himself with the altar which, I have argued, was the focal point of the daily rituals meant to procure water. Additionally, and following from this, he may intend to signify that, like the rock of Meribah, he will be 'struck' (that is, killed) in order to supply this life-water for the people. ${ }^{450}$

I have repeatedly observed that this reading more adequately accounts for the narrative and historical setting of Jesus' words than the more common reading which stops at equating Jesus with the Temple from which eschatological waters flow. From 7:1 to 8:59, the account of Jesus' attendance at this festival is shot through with references to first official then popular hostility threatening him ultimately with death. Against this backdrop, and particularly in light of the exchange about his immanent "departure" in the immediately preceding context (7:32-36), it is most fitting that his declaration on the climactic day of this festival should include tacit reference to the manner in which this latter-day Meribah provision should be brought forth, namely, by his death.

The final contextual horizon to which I will appeal for support of this reading is the report about the piercing of Jesus' side on the cross (19:34). Commentators commonly discern a thematic linkage between 7:37-39 and 19:34 such that the latter represents the symbolic fulfillment of the former. ${ }^{451}$ This interpretation is prompted by the forward-looking future tense of $\dot{\rho} \in \dot{f} \sigma 0 u \sigma \iota \nu$ in 7:38. ${ }^{452}$ Since v.39 both defines the water symbolism with the Holy Spirit and expressly links the coming of the Spirit with

\footnotetext{
${ }^{450}$ Grigsby, "Thirsts", 107, believes the evidence of $t$. Sukk. 3 leads to the identification of Jesus with the rock of Horeb, but the eschatological Temple traditions present in John 7:38 as well as John's association of Jesus with the altar in 10:22-39 suggest that the altar identification may be preferable. The difference is not great, however, since the altar was probably associated with the rock in the symbolism of the daily ceremonies.

${ }^{451}$ Cf. Keener, John, 730; Webster, Ingesting, 56; Burge, Anointed, 93-95; Devillers, Siloé, 86; Brown, Spirit, 161; Grigsby, "Thirsts", 107; Jones, Symbol, 216. Kerr, Temple, 241-243, reads the water and blood of 19:34 as a double reference: on the one hand, to the blood of the Passover lamb (cf. 1:29, 34; ch. 6); on the other hand, to the Spiritwater symbolism (cf. 4:13-14; 7:37-39).

452 So Daly-Denton, David, 152; Menken, “Origin”, 163. Cf. also Grelot, "Jean VII, 38," 49-50, followed by Bienaimé, "L'Annonce” 430.
} 
the cross of Jesus, the report of the flow of water (and blood) in 19:34 seems calculated to recall Jesus' words in 7:38 in order to indicate the symbolic fulfillment of this promise at the moment of his death. Consistent with his use of the Meribah tradition in John 7, Jesus was "struck" on the cross and thereby provided the water that brings life for the people. ${ }^{453}$ Support for this reading has sometimes been sought in later rabbinic sources which expand upon the account of Moses' striking of the rock twice (Num 20:11) by specifying that first blood then water flowed from the rock. ${ }^{454}$ So, for example, Tg. Ps.-J. on Num 20:11 states, "Moses lifted up his hand, and with the rod struck the rock twice: at first it dropped blood, but at the second time there came forth a multitude of waters." Exod. Rab. III.13 similarly reads Num 20:11 with Ps 78:20 as referring to an issue of blood since the verb "went forth" "is an expression used of blood". This material is not reliably early, however, and in any case the literary and symbolic links between John 7:37-38 and 19:34 are adequate to establish the thematic connection between the two passages. ${ }^{455}$

\section{F. Conclusion}

The present chapter has sought to argue the possibility that Jesus' words in the climactic scene of the Tabernacles narrative of John (7:37-38) may be understood with greater precision and depth of significance than is commonly done. Commentators often regard his declaration as associating him with the Temple from which the eschatological waters were expected to flow in fulfillment of Ezek 47 and Zec 14. I have argued that fuller appreciation of the symbolic import of the water, willow and palm ceremonies may invite the reader to associate Jesus not with the Temple generally but with the altar specifically. This follows from a more balanced appropriation of the traditional backgrounds represented in the composite citation at 7:38: whereas a simple Temple association may follow naturally from Ezek 47 and Zec 14, the Ps 78 (Exod 17) background suggests Jesus may associate himself more precisely with the altar as the source of water. Finally, the symbolism of these ceremonies together with the Meribah background may hint that, like the rock in the wilderness, this altar (Jesus) must be struck to provide the life-giving water for the people. This final step more adequately accounts for the manifest atmosphere of mortal threat to Jesus in John 7-8 (an element of the context seldom

\footnotetext{
453 “....in 19:34 where blood and water flow from Jesus' belly, Jesus seems to replace the rock at Horeb” (Brown, Spirit, 162). Cf. Lincoln, Truth, 52-54.

${ }^{454}$ See, e.g., Burge, Anointed, 93-95; Lincoln, John, 479; idem., Truth, 54; Glasson, Moses, 54.

${ }^{455}$ It is noteworthy that early patristic interpretation of John 19:34 commonly viewed the report in terms of Exod 17/Num 20. See discussion in Glasson, Moses, 52-53, and Burge, Anointing, 94.
} 
considered in interpretations of 7:37-38) and dovetails closely with the image of water flowing from his pierced side in 19:34.

I conclude by observing that John's use of the festival of Tabernacles evinces the same view of Judaism as I argued for with Passover in the previous chapter. Jesus does not set aside the various ceremonies associated with the feast. Rather, he evokes prominent Old Testament and contemporary Jewish traditions connected with these ceremonies in such a way as to reveal their eschatological enactment in his very person and work. By entering into the symbolic customs of Tabernacles and "filling them up to the top" Jesus brings to full realization the eschatological, salvific aspirations of those who celebrate the festival. 


\section{Chapter 5}

\section{The role of Dedication John}

\section{A. Introduction}

In the previous two chapters I have examined the manner of use made by John of Passover and Tabernacles in his portrayal of the person and work of Jesus. In both cases the conclusion I arrived at was that John does not undervalue, judge or even set aside the Jewish institution but rather represents Jesus as entering into it and bringing it to its eschatological goal. As I turn to the feast of Dedication I will try to show that the same pattern of thought identified with Passover and Tabernacles is evident in John's use of this third and final feast.

With the feast of Dedication we come to the climactic confrontation in the public ministry between Jesus and the Jewish leaders surrounding his identity (John 10:22-39). At the heart of this passage stands the question of Jesus' identity. ${ }^{456}$ The Jewish leaders surround him and demand a straightforward declaration of whether or not he is the Christ (10:24). In what follows Jesus responds in characteristically elusive terms insisting, ultimately, that the answer to their question is supplied by the works he performs $(10: 25,32,37-38)$. If they believe in the works they will recognize his identity as God.

\section{A.i. Hanukkah background}

The scene is set against the festival of Dedication, or Hanukkah, the eight-day celebration beginning on 25 Chislev and characterized, among other things, by the lighting of candles and lamps in the Temple and private homes. The main sources for the origins of Hanukkah ${ }^{457}$ describe a festival instituted by Judas Maccabeus to celebrate and commemorate the recapture, purification and dedication of the Jerusalem Temple in 164 B.C.E. following the initial Hasmonean victories against the forces of the Seleucid Antiochus IV Epiphanes. In 167 B.C.E. the Seleucid king instituted a policy which brought about the thoroughgoing arrest of Jewish adherence to time-honored facets of the Torah, such as circumcision and Sabbath observance. Perhaps most traumatically from the Jewish perspective he

\footnotetext{
${ }^{456}$ See esp. Lincoln, John, 311: “In many ways [John 10:22-39] presents readers with the Fourth Gospel's controversial Christology in a nutshell, forcing reflection on the appropriate identification of Jesus." Similarly, Carson, John, 390.

${ }^{457}$ The main sources are 1 Macc 4:36-39; 2 Macc 10:1-8; Jos. Ant. 12.316-325.
} 
defiled the Temple and destroyed many of the implements of worship. ${ }^{458}$ Three years later (cf. 1 Macc 1:54; 4:52) Judas recaptured the Temple and promptly cleansed it, consecrated it and inaugurated sacrificial worship once more. The joy at the renewal of Jewish worship was predictably great and gave rise to the annual festival to commemorate the event. ${ }^{459}$

\section{A.ii. Contemporary scholarship}

Typically, scholars locate the significance of this festival background for John 10:22-39 in verse 36 where Jesus speaks of his consecration by the Father. ${ }^{460}$ It is argued that this consecration plays off the tradition wherein Judas consecrated the altar of the recaptured Temple in 164 B.C.E.. Like the altar in the time of Judas, Jesus has been consecrated by the Father to be the new altar of burnt offering, and the inaugural sacrifice (his crucifixion) will take place immanently. ${ }^{461}$

In addition to this reference to Jesus' consecration at John 10:36 some scholars have detected a further allusion to the Hanukkah tradition in the Jewish charge against Jesus of blasphemy (John 10:33). ${ }^{462}$ The application to Jesus of the language of blasphemy and of a mortal making himself God raises the specter of Antiochus and amounts to the insinuation that Jesus is guilty of the same blasphemous pretense as the Seleucid king of old.

I accept both of these interpretations of the role of the Hanukkah setting in the shaping of the theme of the passage and I will not add anything to the arguments put forth by other scholars who have

\footnotetext{
4581 Macc 1:21-23, 41-50, 54, 59.

${ }^{459} \mathrm{Cf}$. Josephus Ant. 12:324 "they were so very glad at the revival of their customs, when, after a long time of intermission, they unexpectedly had regained the freedom of their worship, that they made it a law for their posterity that they should keep a festival, on account of the restoration of their temple worship, for eight days."

${ }^{460}$ There have been scholars who deny any substantial thematic link with the Hanukkah setting, among them Bernard, John, 1.342-343; Schnackenburg, John, 2.305; Barrett, John, 379; (and note the silence of Lindars, John, Dietzfelbinger, Johannes, Schenke, Johannes, and Wengst, Johannesevangelium). A majority, however, favors some connection, typically centering on John 10:36. Cf. Hoskyns, John, 385; Marsh, John, 407; Brown, John, 400, 411; Beasley-Murray, John, 177; Carson, John, 399; Keener, John, 822; Köstenberger, John, 316; Lincoln, John, 309; Moloney, Signs, 149-150; Yee, Feasts, 91; Hoskins, Temple, 171-175; Coloe, Dwells, 151-155; Kerr, Temple, 253-255; Bauckham, "Holiness", 13-16.

${ }^{461}$ Recently, Richard Bauckham has introduced greater terminological precision to the discussion about the name of

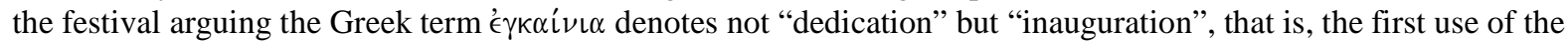
newly purified and consecrated altar. His work brings the festival more nearly into relationship to the altar thereby aligning Jesus with the altar, rather than the Temple, which has been consecrated and will soon become the place of the final sacrifice. See Bauckham, "Holiness", 256-265.

462 James VanderKam, "John 10 and the Feast of Dedication," in Of Scribes and Scrolls: Studies on the Hebrew Bible, Intertestamental Judaism, and Christian Origins, Presented to John Strugnell on the Occasion of his Sixtieth Birthday (eds. Harold W. Attridge, John J. Collins, Thomas H. Tobin; Lanham: University Press of America, 1990) 213: "Jesus' unbelieving audience who do not belong to his sheep see in the divine Son only another blasphemer who, like the Seleucid king, claimed to be god." See also Keener, John, 822, 827; Moloney, Signs, 149 n.22; Kerr, Temple, 252 and n.135; Coloe, Dwells, 149; also Schnackenburg, John, 2.309, who suggests the expression moıєi $\varsigma$

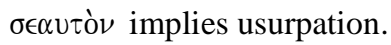


advocated for them. I do wish to suggest, however, that the full bearing of the Hanukkah tradition for John 10:22-39 has not been appreciated. The extensive use of symbolism from other Jewish feasts in the Gospel justifies the expectation of a comparable use of Hanukkah traditions in this context. Indeed, the care with which the author has introduced this climactic section of Jesus' public ministry in relationship to Hanukkah suggests that the symbolism and traditions surrounding the Jewish feast may be expected to play a more pervasive role in the scene than is commonly allowed. ${ }^{463}$ This is not to suggest that the connections with Hanukkah are as clear or forceful as with Passover or Tabernacles in earlier chapters of the Gospel, for this is surely not the case. Rather, I wish to argue simply that a fuller appreciation of the historical background of the feast yields greater interpretive clarity for this passage. ${ }^{464}$

In what follows, I will argue that the message of John 10:22-39 as a whole, rather than merely 10:33 and 36, finds a highly appropriate symbolic and historic setting in the feast of Hanukkah. In a word, it is unto worship of Jesus as the one true God that Jesus reveals his deity when he brings national restoration by giving life and judging.

\section{B. Exegesis of John 10:22-39}

For full apprehension of the significance of Hanukkah for John 10:22-39 the passage must be understood in terms of its unique role as the climax of the opposition to Jesus begun in chapter 5 . "Chapters 5 and 10 form an inclusio on the theme of conflict." ${ }^{465}$ This conflict revolves around the question of Jesus' identity and this, in turn, revolves around the works he performs. The section is comprised of a series of miracles coupled to explanatory discourses which draw out the significance of these works for the question of his identity. ${ }^{466}$

\footnotetext{
${ }^{463}$ So, for example, Thyen, Johannesevangelium, 496, highlights the "highly symbolic mode" of the scene: "Daß der

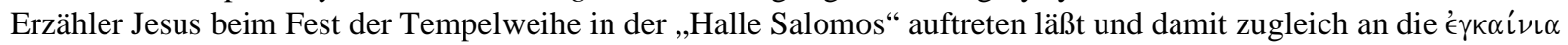
des Tempels durch Judas Maccabaeus und an seine ursprüngliche Weihe durch Salomo erinert, dürfte schon ein erstes Indiz für den hochsymbolischen Modus unserer Szene sein". This may be unduly cautious (“dürfte...sein") for, as we have seen, the Fourth Gospel makes extensive use of the symbolism surrounding the Jewish feasts. ${ }^{464}$ VanderKam, "John 10", 205, 207 also notes the widespread lack of scholarly appreciation of the historical backdrop of John 10:22-39. Cf., also, Keener, John, 822; Stephen Motyer, Your Father the Devil? A New Approach to John and 'the Jews' (Carlisle: Paternoster Press, 1997), 124-125.

465 John Painter, "Tradition, History and Interpretation in John 10," in The Shepherd Discourse of John 10 and its Context (eds. Johannes Beutler and Robert Fortna; Cambridge: Cambridge University Press, 1991) 53. Commenting on the relation of John 10:22-30 both to chs. 5-9 and 11-12, Robert Kysar, "John 10:22-30," Int 43 (1989) 66, notes the strategic positioning of the passage "at the center of the tidal wave of opposition."

${ }^{466}$ That each miraculous work forms the basis of the subsequent discourse or debate about the identity of Jesus is evident in each discourse: 5:16-18; 6:25-27; 9:16, 24-33. Note, also, that the discourses of John 7-8 are set against the work of Jesus in John 5 (cf. 7:3, 20-23, 31).
} 
As stated expressly in the discourse of John 5:19-30 the works of Jesus are to give life and judge. "As the Father raises the dead and gives life, so also the Son gives life to whom he wills" (5:21). The lifegiving work of Jesus is everywhere evident throughout John's narrative of his public ministry. Thus, he gives the "living water" which yields eternal life (4:10-14; 7:37-39) and he provides the "bread of life" that "any may eat and live forever" (6:50-51). On the other hand, the Father "has given him authority to render judgment" (5:27; cf. v.21). Though this judgment can be regarded as self-imposed by those who reject Jesus (cf. 3:19-21, 36; 5:45; 12:48) and though the primary purpose of Jesus' initial coming was not to judge anyone (cf. $3: 17 ; 12: 47$ ), he anticipates his role as eschatological judge at select points in the narrative when he brings judgment upon Israel's unfaithful leaders. ${ }^{467}$ He makes this explicit in the conclusion to the episode of the blind man (9:39-41; cf. 8:26) and the condemnation and replacement of the Jewish leaders by a "good shepherd" becomes an orienting theme for the discourse that follows in 10:1-21. ${ }^{468}$ Moreover, the traditions about resurrection, judgment and the Son of Man in Dan 7 and 12 and Ezek 37 supply the essential conceptual background for John 5:19-30. In this way, the author represents the works Jesus performs as nothing short of the realization of the nation's hope for full restoration from exile. ${ }^{469}$

A further point must be noted in regard to the works Jesus does in John 5-10: namely, giving life and judging are the quintessential works of God. ${ }^{470}$ This belief finds expression at the culmination of the polemic against foreign gods in the Song of Moses where God asseverates, "See now that I, even I, am he, and there is no god beside me; I kill and I make alive" (Deut 32:39). Commenting on this traditional background in John, Bauckham insists,
"Such divine prerogatives should be understood not as mere functions that God might delegate to others, but as intrinsic to his divine identity. Ruling over all, giving life to all, exercising judgment on all - these prerogatives belong integrally to the Jewish understanding of who God is." ${ }^{471}$

\footnotetext{
${ }^{467}$ Tim O'Donnell, "Complementary Eschatologies in John 5:19-30," CBQ 70 (2008) 750-765, offers an incisive, up-to-date treatment of the present-future tension in John's presentation of Jesus' works of giving life and judging, with particular reference to John 5:19-30.

468 “....das neue zehnte Kapitel fast besser mit 9:40 begönne” (Hartwig Thyen, "Johannes $10 \mathrm{im}$ Kontext des vierten Evangeliums," in The Shepherd Discourse of John 10 and its Context (eds. Johannes Beutler and Robert Fortna; Cambridge: Cambridge University Press, 1991) 123). For the syntactical and narratological unity of John 9-10 see Jan Du Rand, "A Syntactical and Narratological Reading of John 10 in Coherence with Chapter 9," in The Shepherd Discourse of John 10 and its Context (eds. Johannes Beutler and Robert Fortna; Cambridge: Cambridge University Press, 1991) 94-115.

${ }^{469}$ For the restorational shape the discourse of John 5:17-30 see especially Manning, Echoes, 160-171.

${ }^{470}$ For this notion, see esp. Bauckham, "Monotheism", 152-153; Keener, John, 650-652; Brown, John, 218-219.

${ }^{471}$ Bauckham, "Monotheism", 152.
} 
Bauckhams' interpretation of Deut 32 finds expression in the exasperated outburst of the King of Israel upon learning of the request of the king of Syria that he heal his servant of leprosy (2 Kgs 5:7): "Am I God, to kill and to make alive, that this man sends word to me to cure a man of his leprosy?" Within the second Temple period, Wis 15: 16-17 approximates this same perspective in a discussion of the folly and misery of the pagan who worships idols: "For a man made them, and one whose spirit is borrowed formed them; for no man can form a god which is like himself. He is mortal, and what he makes with lawless hands is dead, for he is better than the objects he worships, since he has life, but they never have." As von Wahlde observes, this text makes no express claim about the unique prerogative of God to give life, but evinces, rather, the view that the prerogative belongs to no human being. ${ }^{472}$ The performance of the works of giving life and judging that the Father has entrusted to Jesus, therefore, reveals that Jesus is "equal with God" (5:18). ${ }^{473}$

Furthermore, the works aim, ultimately, to elicit worship of his person comparable to that offered to the only God. This conclusion flows naturally from the fact that God has delegated to Jesus the work that only God does and is made explicit in Jesus' words at 5:23, "in order that all might honor the son even as they honor the father. ${ }^{\prime \prime 74}$ The narrative of the healing of the blind man in chapter 9 illustrates this goal in symbolic fashion. ${ }^{475}$ The restoration of the man's sight forms the third and final 'work' Jesus does in chapters 5-10 and culminates with the healed man worshipping Jesus (9:38 к $\alpha i$

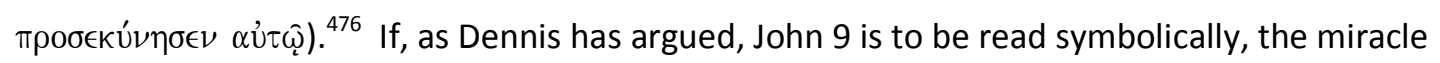

\footnotetext{
${ }^{472}$ Urban C. von Wahlde, "He has Given to the Son to have Life in Himself (John 5,26)" Bib 85 (2004) 410. For other expressions of this belief in second Temple Judaism, see literature cited in Keener, John, 650-651.

${ }^{473}$ Von Wahlde concludes, "Thus the fact the Father has life in himself sets him apart from all humanity. Moreover the fact that the Father gives to the Son to have life in himself not only sets the Son apart and identifies him as divine also but provides the basis for his ability to give life to others" (John 5,26", 411).

${ }^{474}$ See esp. Carson, John, 254-255; Keener, John, 650; Bauckham, "Monotheism", 152-153. Barrett, John, 260, says this idea is implicit already in 5:17, the text elaborated by the discourse that follows.

${ }^{475}$ A striking degree of parallelism between John 5 and 9 suggests that the chapters be read in connection with each other. For a list of parallels with succinct discussion see Keener, John, 639; R. Alan Culpepper, Anatomy of the Fourth Gospel: A Study in Literary Design, New Testament, (Philadelphia: Fortress Press, 1983), 139.

476 "This is the climax of the narrative and the purpose for which it was told" (Hoskyns, John, 359). Schnackenberg, John, 2.254 (followed by Beasley-Murray, John, 159-160) is more hesitant to admit of more than reverence such as could be given any person. Carson, John, 377, similarly doubts whether wider Gospel context yet necessitates this.

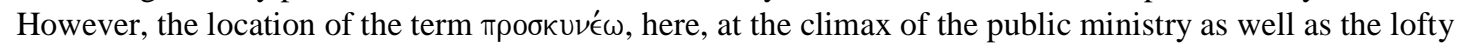
Christological program of the Gospel as a whole support the idea of "worship". Moreover, the close parallelism between John 5 and 9 (see Culpepper, Anatomy, 139; Keener, John, 639) supports a link with the stated goal of Jesus' works at 5:23: "that all might honor the son even as they honor the Father." See further, Barrett, John, 365; Keener, John, 795; Lincoln, John, 287; Köstenberger, "Destruction”, 238.
} 
represents the work of salvation Jesus came to perform and the man's worship of Jesus represents the goal of this salvation. ${ }^{477}$

This complex of themes (national restoration, judgment of the Jewish leaders and worship of Jesus) reaches its climax in the final dispute with the Jewish leaders in the Temple during Hanukkah (John 10:22-39). Appropriately, the scene is cast in terms of a trial and the works of Jesus serve as the leading witness to his identity (cf. John 5:36). ${ }^{478}$ The "Jews" commence the interrogation by asking whether Jesus is the Messiah (John 10:24). Jesus implicitly accepts the title (v. 25) but goes on to transcend messianic categories by claiming to be "one" with the Father (v. 30) thereby "making himself God" (v.33). ${ }^{479}$ The scene reaches its conclusion with the third assertion of Jesus' deity, "I am in the Father and the Father is in me" (v. 38), prompting the Jews to try to arrest him. For the present purposes, the important point to note is the basis on which Jesus rests his claim to deity: the evidence of the works he has been doing (John 10:25, 32, 37-38). These works bear out not only that he is Messiah but that he is "one" with the Father and that "the Father is in me and I am in the Father." ${ }^{480}$ Therefore, at the heart of this climactic moment in Jesus' public ministry is the relationship between his works and

\footnotetext{
${ }^{477}$ Dennis, Gathering, 219-231.

${ }^{478}$ Indeed, John 5-10 has been shaped at many points in such a way as to cast the entirety of Jesus' public ministry in terms of a trial. This has often been attributed to John's reworking of the Synoptic Passion material, in particular the trial scene before Caiaphas (altogether absent from the Passion Narrative in the Fourth Gospel). In this way, the essentially forensic scene in John 10:22-39 functions as the highpoint in Jesus' trial before the Jewish leadership. See the discussions in Pancaro, Law, 64-71; Lincoln, Truth, 21-29; M. Sabbe, "John 10 and its Relationship to the Synoptic Gospels," in The Shepherd Discourse of John 10 and its Context (eds. Johannes Beutler and Robert Fortna; Cambridge: Cambridge University Press, 1991) 75-85; and cf. Painter, "Tradition”, 68; Thyen, "Johannes $10 ”, 132$.

${ }^{479}$ Bauckham, "Monotheism," 163, argues that Jesus alludes in 10:30 "to the Jewish confession of faith in the one God, the Shema" of Deut 6:4: "the Lord our God, the Lord is one." He explains the shift from the masculine $\epsilon \hat{i} \varsigma$ of the LXX to the neuter " $ै \nu$ of John 10:30 as "a necessary adaptation of language" signifying that Jesus and the Father are one God, as opposed to one person. Also arguing for an allusion to the shema are Carson, John, 394-395; Köstenberger, John, 312; Keener, John, 826 (though he explains the change to neuter " $v$ as indicative of "unity of purpose rather than identity of person"; so, also, [though without reference to the shema] Haenchen, John, 2.50; Wengst, Johannesevangelium, 392-393, who sees a conceptual parallel in the relationship between Paul and Apollos in 1 Cor 3:8; Thyen, Johannesevangelium, 499, who draws a parallel in Paul to "der Metaphorik des Leibes und seiner Glieder").

${ }^{480}$ Cf. Pancaro, Law, 74-76; Kysar, “John 10:22-30”, 68; Ridderbos, John, 371 (citing Calvin); Carson, John, 394; Beasley-Murray, John, 174. Schnackenburg, John, 2.308, argues that the formulation of 10:30 surpasses anything found in 5:17-30: "In the short sentence, a vista appears of the metaphysical depths contained in the relationship between Jesus and his Father." Schenke, Johannes, 205, calls Jesus' statement "den ersten absoluten Spitzensatz johanneischer Theologie", and draws out some of the mystery alluded to by Schnackenburg: "Diese mythische Einheit gilt, obwohl der Mensch Jesus auf Erden ist, der Vater aber im Himmel, obwohl Jesus einst "von Gott ausgegangen" ist und später wieder "zu ihm zurückkehren" wird. Sie ist im raum-zeitlichen Sinne nicht objektivierbar. Es wird keine Identität behauptet, sondern ein Paradoxon. Jesus ist nicht der Vater in Person, und doch kann er mit der Offenbarungsformel "Ich bin" (vgl. Jes 43,10f.; Ex 3, 14) geheimnisvoll auf sich selbst hinweisen: In ihm ist Gott unter den Menschen in Zeit und Geschichte erschienen und anwesend. Der Satz faßt zusammen, was Jesus bisher über das Verhältnis zwischen ihm und dem Vater gesagt hat: 3,35: 5,17.19-29; 6,20.45: 8.19.24.28.58: diese Aussagen sollen mitbedacht werden." (italics mine)
} 
his divine identity. Moreover, just below the surface of the dialogue stands the issue of the worship of Jesus which the foregoing narratives have linked with the question of identity and mission.

The festival of Hanukkah supplies the ideal setting for the climactic dispute concerning the works and identity of Jesus because a prominent tradition interprets the divine deliverance which gave rise to the first Hanukkah as a display of the works which show that the God of Israel is the only true God worthy of worship. I must now turn to a consideration of how this tradition bears more fully on our passage.

\section{Re-appraisal of 2 Maccabees}

An important dimension of the Hanukkah tradition which is not always given adequate attention in discussions of John 10:22-39 is the divine self-conception of the Seleucid king Antiochus IV Epiphanes, the challenge this posed to Judaism, and the way its resolution became bound up with popular thought during the feast of Hanukkah. I will argue that this background, when fully brought to bear, informs the meaning of the works of Jesus in relation to the question of his divine identity.

Ancient sources attest the divine pretensions of the pagan king Antiochus in several ways. Most immediately, the king's title gives evidence of this pretense for it indicates his self-conception as God "manifest". In his Antiquities of the Jews (12.258), Josephus reports that the Samaritans addressed Antiochus as "King Antiochus the god, Epiphanes." Seleucid coins from the period of Antiochus' reign corroborate this formula of address. Coins, for instance, with the inscription BA $\Sigma I \Lambda E \Omega \Sigma$ ANTIOXOY $\Theta E O Y$ EПIФANOY $\Sigma$ have been dated to c. 173-164 B.C.E. ${ }^{481}$

Undoubtedly, the high water mark of Antiochus' blasphemy, from Jewish perspective, was his replacement of the Jewish cultic calendar and system of worship with the Seleucid system involving worship of his own person. Second Maccabees 6:1-7 reports the radical and thoroughgoing persecution under Antiochus directed against the central Jewish religious customs. The king appointed an "Athenian senator" to put an end to Jewish observance of their ancestral customs, to defile the Temple in Jerusalem and rededicate it to Zeus thereby bringing to a halt all Temple-related festivities. Verse 7

\footnotetext{
${ }^{481}$ James VanderKam, “John 10," 212, has surveyed a considerable range of evidence attesting the king's conceit in this regard. In addition to the numismatic evidence, see, e.g., Polybius, Histories, 5.483 (Book 26.1,7); and the evidence from Daniel 7:8, 20-21, 25; 8:10-11, 25; 11:36-37. Otto Morkholm, Antiochus IV of Syria (København : Nordisk, 1966), 130-132 (cf. also 113), in his helpful discussion of the evidence, argues that the arrogation of the title "God manifest" was perfunctory at best and intended to promote certain political, rather than purely religious, goals. Use of the title seems to have been confined to a small area of his kingdom (including Judea) and to only a decade or so of his reign (c. 173/2-164 B.C.E.). Nevertheless, whatever Antiochus' true intentions, it is no stretch to suppose that the fiercely monotheistic Jews seized upon such a title and incorporated the implicit claim to deity into their polemic against the king. In the hands of an author of a work like 2 Maccabees the pretentious title is eminently useful for the thematic program of exalting the uniqueness of Israel's God.
} 
goes on to report that "on the monthly celebration of the king's birthday, the Jews were taken, under bitter constraint, to partake of the sacrifices". ${ }^{482}$ James VanderKam has argued thoroughly that the sacrifices mentioned in 2 Macc 6:7 should be identified with those mentioned at 1 Macc 1:59: "On the twenty-fifth day of the month they offered sacrifice on the altar that was on top of the altar of burnt offering." ${ }^{483}$ Together, these two passages reveal that Antiochus did not simply halt Jewish Temple worship but replaced it with a new system of worship which included worship of himself as a god. This worship was to take place every month on the occasion of his birthday. "By participating in these rituals, Hellenized Jerusalem, perhaps now renamed Antiochia, took its place in the lists of Greek cities which, as theoretically independent entities within the Seleucid realm, offered worship to the deified king in the manner chosen by them." 484

Antiochus' oppression of Judaism, then, was bound up with his claim to deity and worthiness of worship. From a Jewish perspective, the pagan king did not merely repress Jewish religious expression, he blasphemously reoriented it toward himself. He replaced the true God as the object of the people's worship.

It is not hard to imagine that future celebrations of Hanukkah would conjure memories not only of the inauguration of the new Temple altar but also of the wider circumstances against which the inauguration of the altar became so meaningful. In this way Hanukkah would become a celebration not merely of the renewal of stalled Temple worship, but of the reorientation of worship from the pagan oppressor Antiochus back to the one true God of Israel.

This supposition receives support from 2 Maccabees, an early Jewish work that yields important insight into how some prominent Jews elaborated this dimension of Hanukkah tradition. Second Maccabees shows that Hanukkah could be associated with the display of God's unique power, and therefore sole worthiness of worship, when he worked salvation for his people and judged their oppressors. Because the bearing of 2 Maccabees on John 10 has not been sufficiently appreciated in the past, I will devote extended space to a survey and evaluation of the relevant material.

\footnotetext{
${ }^{482}$ For a survey of the turn of events under this "Athenian senator", see Morkholm, Antiochus IV, 146-148.

483 James VanderKam, "2 Maccabees 6,7a and Calendrical Change," JSJ 12 (1981) 61-68 (esp. 63), points to the common context of the passages, the mention of a monthly ritual and the involvement of sacrifice in support the identification of the festival offerings in the two passages.

${ }^{484}$ VanderKam, "2 Maccabees," 63. For the probable renaming of Jerusalem "Antiochia", see Morkholm, Antiochus $I V, 145$. VanderKam goes on to adduce four inscriptions ranging from the third century B.C.E. to the first and spanning three Hellenistic kingdoms which show that "monthly birthday rituals were a normal part of the ruler cults that became standard fare in the Hellenistic states, probably by the second generation of rulers" (64). The inscriptions examined are: the Decree of Canopus, II.33-34; the Rosetta Stone, II.46-48; a text from Sestos, II.35-37; a text from Antiochus I Comagene, II.82-86.
} 


\section{C.i. Currency in the first-century C.E. of the traditions in 2 Maccabees}

Second Maccabees consists broadly of two sections. The openings chapters (2 Macc 1-2) contain two letters from Jewish leaders in Jerusalem introducing the historiographical section and commending it to "the Jews in Egypt" (cf. 1:1, 10). The opening letters purport to originate in Jerusalem: the first from Jewish leaders in 124 B.C.E. (cf. 1:9); the second from the hand of Judas Maccabeus himself. While most scholars accept the authenticity of the first letter ${ }^{485}$, few regard the second as authentic, ${ }^{486}$ with "dates between 77 B.C.E. and the reign of Nero [having] been proposed without any decisive evidence." ${ }^{487}$ Moreover, neither the first letter (2 Macc 1:1-10a) nor the second (2 Macc 1:10b$2: 18)$ likely originates with the author of the "epitome" (2 Macc 3-15). The first letter shows signs of abridgement from an earlier festal letter that has been reworked to match the focus of 2 Macc 3-15. The second contains a major discrepancy with 2 Macc 3-15 in the description of the death of Antiochus, as well as in certain other emphases. ${ }^{488}$ Most scholars, therefore, conclude that the letters were added to the epitome subsequently, perhaps in stages, for the purpose of commending the festival of Hanukkah and setting it against the conceptual backdrop developed by the epitome of chs 3-15. ${ }^{489}$ The main body of 2 Maccabees (chs 3-15) recounts Antiochus' oppression of the Jews and Hasmonean resistance. Though the section that expressly describes the institution of Hanukkah (2 Macc 10:1-9) occupies a relatively small portion of the overall work, yet the second introductory letter commends the whole historical work as vital context for the celebration of Hanukkah (cf. 1:18; 2:16-18). Indeed, it is with a view toward encouraging the Jews of Egypt to join them in celebrating the festival of Dedication that the Jews in Jerusalem append the history recorded in chapters 3-15. ${ }^{490}$ The second

\footnotetext{
${ }^{485}$ E.g., J.A. Goldstein, II Maccabees (AB 41a; New York: Doubleday, 1983) 145-151; David S. Williams, "Recent Research in 2 Maccabees," CBR 2 (2003) 72; Jan Willem Van Henten, The Maccabean Martyrs as Saviours of the Jewish People: A Study of 2 and 4 Maccabees (Leiden: Brill, 1997), 37.

${ }^{486}$ Goldstein, II Maccabees, 157-158; Williams, "2 Maccabees," 72-73; Van Henten, Martyrs, 37; Robert Doran, "2 Maccabees," in New Interpeter's Bible (ed. Leander Keck; Abingdon Press, 2003) IV.191; idem., Temple Propaganda: The Purpose and Character of 2 Maccabees, (Catholic Biblical Quarterly Monograph Series 12; Washington D.C.: Catholic Biblical Association, 1981), 6-11. Contra, for example, B.Z. Wacholder "The Letter from Judah Maccabee to Aristobulos: Is 2 Maccabees 1:10b-2:18 Authentic?" HUCA 49 (1978) 89-133; T. Fischer, "Maccabees, Books of," in The Anchor Bible Dictionary (ed. David Noel Freedman, New York: Doubleday, 1992) 4. 444, who regards the letter as "the sole authentic surviving record of Judas Maccabeus himself."

${ }^{487}$ Harold Attridge, "2 Maccabees," in Jewish Writings of the Second Temple Period: Apocrypha, Pseudepigrapha, Qumran, Sectarian Writings, Philo, Josephus. Compendia Rerum Iudaicarum Ad Novum Testamentum (ed. M.E. Stone; Philadelphia: Fortress, 1984) 178.

${ }^{488}$ See Doran, Temple, 3-12.

${ }^{489}$ See Williams, “2 Maccabees," 73; Van Henten, Martyrs, 41-43; Doran, "2 Maccabees,” 184; Goldstein, II Maccabees, 545-57.

${ }^{490}$ The final form of 2 Maccabees has been shaped in such a way as to orient the celebration of Hanukkah urged by the letters around the history outlined in chapters 3-15 (see esp. Van Henten, Martyrs, 47-50). The history portrays the inauguration of Hanukkah as the celebration of the beginning of the shift from divine wrath to mercy, a shift triggered by the sacrificial deaths of the seven brothers in chapter 7 and evidenced by the incipient victories of the
} 
letter, particularly, orients subsequent celebration of the festival not only backward in time as an expression of thanksgiving for God's deliverance from the pagan king, but forward in time as a petition for God to gather the Jews dispersed among the Gentiles. ${ }^{491}$ Thus, 2 Maccabees in its present form witnesses to the view of Hanukkah held by some prominent leaders in Jerusalem from the early first century B.C.E. and propagated by them in other Jewish communities at that time.

The question, of course, must be asked whether the view of Hanukkah represented by 2 Maccabees remained current in first century C.E. Judaism. Though direct evidence is scant, considerable circumstantial evidence suggests the likelihood of its currency. ${ }^{492}$ In the first place, several literary works from the first century C.E. drew heavily from 2 Maccabees (especially the martyr accounts in chs 6-7), thereby indicating the persistent popularity of the latter work. In the first century C.E. work, Assumption of Moses, the author depicts the suffering and struggle of the people under Herodian and Roman (procurator) rule (chs 5-7) culminating in the martyrdoms of Taxo and his seven sons (chs 8-9) followed by divine deliverance and exaltation of the people (ch 10). Evident dependence of the author on 1 and especially 2 Maccabees for the shape of the account prompts Cummins to observe, "notable amongst its features is that it clearly indicates that the vicissitudes of early first-century Judaism were being interpreted by reference to the Maccabean crisis, and indeed responded to by means of a martyrfocused suffering and vindication schema consonant with that discerned in the earlier analysis of formative Maccabean texts." ${ }^{493}$

Another first century C.E. work, Megillath Taanit, draws on past Jewish victories celebrated at Hanukkah and Nicanor's day to inspire continued resistance against Rome in the pre-70 C.E. period. ${ }^{494}$

Jewish army under Judas in chapter 8 (Van Henten, Martyrs, 256; idem., "The tradition-Historical Background of Rom 3,25: A Search for Pagan and Jewish Parallels," in From Jesus to John: Essays on Jesus and New Testament Christology in Honour of Marinus De Jonge (ed. Martinus C. De Boer; Journal for the Study of the New Testament Supplement Series, 84; Sheffield: JSOT Press, 1993) 117, 120; Marinus deJonge, “Jesus' Death for Others and the Death of the Maccabean Martyrs," in Text and Testimony: Essays on New Testament and Apocryphal Literature in Honour of A.F.J. Klijn (eds. T.Baarda, A. Hilhorst, G.P. Luttikhuizen, A.S. van der Woude; Kampen: Kok, 1988) 148). The letters, then, set the festival against the backdrop of the "restoration of the ideal theocratic order described in the history of 2 Macc 3-15" (Van Henten, Martyrs, 43).

${ }^{491}$ Cf. 2 Macc 1:25-29 and esp. 2:16-18. Goldstein, II Maccabees, 187, approximates the same conclusion: "a result of the observance of the Days of Purification may be that God will fulfill his promises, including the ingathering of the dispersed exiles."

${ }^{492}$ Much of what follows draws on the recent work of Stephen Anthony Cummins, Paul and the Crucified Christ in Antioch: Maccabean Martyrdom and Galatians 1 and 2 (Society for New Testament Studies Monograph Series; Cambridge, U.K: Cambridge University Press, 2001), 54-83, who gathers substantial literary and historical evidence for the widespread currency of the events, heroics and personalities of the Maccabean age down to the first century C.E. Particularly important, he contends, is the legacy of the martyrdoms of 2 Maccabees for Jewish self-view during the travails of the first century C.E..

${ }^{493}$ Cummins, Maccabean, 73.

${ }^{494}$ Cummins, Maccabean, 76, adduces entries for 25 Kislev (Hanukkah), 13 Adar (Nicanor's Day). These show continued celebration of these festivals in first century Judaism as well as their use by Megillath Taanit for 
The inclusion of these festivals in the work also indicates their continued observance in the first century C.E. (see further below). Finally, late-first century C.E. work 4 Maccabees retells the story of the maccabean martyrdoms in different form. ${ }^{495}$ Drawing particularly from 2 Macc 6-7, 4 Macc 8-14 probably reflects the most "vibrant testimony to the ongoing influence of the Maccabean martyr traditions." ${ }^{\prime 496}$

In addition to the literary evidence, substantial historical evidence from the first century C.E. points to the likelihood that the Hanukkah traditions enshrined in 2 Maccabees continued to bear on the thought of first-century C.E. festival observers. I have already mentioned the continued celebration of the festivals of Hanukkah and Nicanor's day, the festivals commemorating the victories of Judas Maccabeus (cf. 1 Macc 4:59; 7:49; 2 Macc 10:8; 15:36). Besides Megillat Taanith, observance of the festivals is attested in Josephus (Ant. 12.324-325) and, of course, John 10 itself. ${ }^{497}$

Cummins, following and extending the conclusions of William Horbury, has argued that memories of the Maccabean era remained vital, in part, through the prominent role played by the Son of Man in messianic expectation throughout the centuries following the Hasmonean period. ${ }^{498}$ The Son of Man figure of Daniel 7, a text widely supposed to have been composed in the wake of the Maccabean crisis, receives later attention and elaboration in 4Q246, the parables of 1 Enoch (37-71), and 4 Ezra. "In this way, Daniel 7, and thus the Maccabean crisis and its outworking, continued to be an important

inspiration against Rome! See also the discussion in Étienne Nodet, "La Dedicace, Les Maccabées et Le Messie," RB 93 (1986) 357-360; William Reuben Farmer, Maccabees, Zealots and Josephus: An Inquiry into Jewish Nationalism in the Greco-Roman Period (New York: Columbia UP, 1956), 154-158 (cf. his succinct discussion of the dating of the document in the Appendix, 205-210).

495 "The differing forms point to a popular oral tradition which remembered their heroic piety, not simply to two authors who recorded their deeds" (Marcus J. Borg, Conflict, Holiness \& Politics in the Teachings of Jesus, Studies in the Bible and Early Christianity, v. 5 (Lewiston, N.Y: Edwin Mellen Press, 1984), 70).

${ }^{496}$ Cummins, Maccabean, 83. For more in-depth discussion of the development of the Maccabean martyr tradition in 4 Maccabees, see Cummins, Maccabean, 79-83; and Van Henten, Martyrs, 58-81 (esp. 70-73). The current consensus strongly favors dating 4 Maccabees to the mid- to late-first century C.E. (cf. Van Henten, Martyrs, 73-81; David A. deSilva, 4 Maccabees: Introduction and Commentary on the Greek Text in Codex Sinaiticus (Septuagint Commentary Series (SEPT); Leiden: Brill, 2006), xiv-xvii; George W. E. Nickelsburg, Jewish Literature Between the Bible and the Mishnah: A Historical and Literary Introduction (Philadelphia: Fortress Press, 1981) 226).

${ }^{497}$ See esp. Farmer, Maccabees, 132-151. He notes (139) the unbroken continuity in festal observance implied by the present tense in Josephus' statement ("from that time until the present we are observing this festival") as well as Josephus' investment of the festal decree with the authority of Torah ("law"). These points are of course complementary, for if the feast attained the status of Law then it would naturally be expected to be observed without interruption.

${ }^{498}$ Cummins, Maccabean, 42-52. Cf. William Horbury, Messianism Among Jews and Christians: Twelve Biblical and Historical Studies (London: T \& T Clark, 2003), 33-34, 83-86. 
backward reference point for Jewish aspirations of a deliverer who would represent, redeem and vindicate afflicted Israel." ${ }^{499}$

A number of scholars have argued that the first century C.E. resistance movements bear a "close correspondence" both in "fundamental distinctives and disposition" to the Maccabean movement. ${ }^{500}$ Both Farmer and Hengel enumerate the commonalities between the Maccabean rebels and the resistance movements of the first century C.E.. ${ }^{501}$ These include such features as a strenuous commitment to Torah, even to the point of death; preference for suicide to surrender to the enemy; strict observance of the Sabbath; and deep devotion to the Temple as the center of Jewish life. Hengel has drawn attention, further, to the common appropriation of Phineas as a model for eschatological zeal which justifies flight to the wilderness and armed, violent revolt against the foreign occupiers.

Finally, Cummins also argues for the likelihood that Palestinian Jews perceived the Caligula crisis in Maccabean terms. ${ }^{502}$ Drawing heavily on the work of Gerd Theissen and N.H. Taylor, he views the "desolating sacrilege" of Mark 13 as referring to this crisis and as casting it in terms of Antiochus IV's desolation of the sanctuary in 167 B.C.E.. From a Jewish perspective, the edict of Caligula represented the most severe threat to Temple purity since Antiochus. ${ }^{503}$ The form taken by Jewish resistance to the Emperor's edict (willing submission to martyrdom) emulates "the response of their forebears to Antiochus IV Epiphanes".

\footnotetext{
${ }^{499}$ Cummins, Maccabean, 47. A number of second century B.C.E. texts suggest that the figure of Antiochus IV Epiphanes may also have contributed to the perpetuation of the memory of the Maccabean era in a manner analogous (but opposite) to the Son of Man. For example, Sib. Or. 3.611-615 (from the mid-second century B.C.E.) "may be influenced by the recent memory of Antiochus" in its prophecy that "a great king will come from Asia... who will cover the whole land with infantry and cavalry...he will overthrow the kingdom of Egypt" (J.J. Collins, "Sibylline Oracles," in The Old Testament Pseudepigrapha and the New Testament: Prolegomena for the Study of Christian Origins (ed. James Hamilton Charlesworth; Society for New Testament Studies Monograph Studies; Cambridge: Cambridge University Press, 1985) 375). Magen Broshi and Esther Eshel, "The Greek King is Antiochus IV (4QHistorical Text = 4Q248)," JJS 48 (1997) 120-129, has argued that 4Q248, a fragment dating to around 30 B.C.E., forms part of a larger historical account of the works of the Seleucid king in the years 170-168 B.C.E. and was composed at the end of this period immediately before the religious persecution in Jerusalem. He suggests the work served as a source for some of the material in Daniel 7-12 and so was preserved and studied alongside Daniel at Qumran. Finally, 4Q246, which dates to the Seleucid period, may have patterned the antiChrist figure after Antiochus (cf. Émile Puech, "Fragment d'une Apocalypse en Araméen (4Q246 = pseudo-Dan ${ }^{\mathrm{d}}$ ) et le 'Royaume de Dieu'," RB 99 (1992) 130; Edward M. Cook, “4Q246,” BBR 5 (1995) 64-65).

${ }^{500}$ Cummins, Maccabean, 61 (cf. 56-61). This argument was first made at length by Farmer, Maccabees; and extended, with modifications, by Martin Hengel The Zealots: Investigations into the Jewish Freedom Movement in the Period from Herod I Until 70 A.D. (Edinburgh: T. \& T. Clark, 1989).

${ }_{501}^{501}$ See Farmer, Maccabees, 47-83; and Hengel, Zealots, 171-173.

${ }^{502}$ Cummins, Maccabean, 66-72. The emperor Gaius Caligula attempted to have a statue of himself erected in the Jerusalem temple in the year 39-40 C.E.. See, for example, Jos. Ant. 18.256-309; Philo Leg. 197-227.

${ }^{503}$ N.H. Taylor, "Palestinian Christianity and the Caligula Crisis," JSNT 61 (1991) 102-103.
} 
I conclude that, though it is not possible to be certain of the extent of Jewish familiarity with 2 Maccabees, yet the circumstantial evidence described above suggests that the traditions represented in the work remained current in popular memory and imagination. One is justified, therefore, in giving special attention to 2 Maccabees for insight into the traditions surrounding Hanukkah in the first century C.E..

\section{C.ii. Contribution of 2 Maccabees to John 10}

The value of 2 Maccabees for understanding the association of Hanukkah with worship of the one true God lies in the way in which its narrative unfolds a lengthy polemic against the blasphemous pretensions of the Seleucid king. This polemic becomes important for our study of John 10:22-39 both for the language employed to characterize Antiochus as well as in the resolution given the theological conflict between the pagan king and God.

The author characterizes Antiochus as a divine pretender of titanic proportions by repeatedly coupling reports of the king's actions to editorial insertions about the king's psychology meant to evoke deity. ${ }^{504}$ For example, following Antiochus' initial plundering of the Jerusalem Temple, the author says,

Antiochus carried off eighteen hundred talents from the temple, and hurried away to Antioch, thinking in his arrogance that he could sail on the land and walk on the sea, because his mind was elated. ${ }^{505}$

Though the precise phraseology does not seem to be drawn from any single Biblical source, the imagery of "walking on the sea" is used repeatedly in the LXX to set God apart from human creatures. For example, Job declares of God, "He alone stretches out the heavens and treads on the waves of the sea [LXX adds 'as on dry ground']." ${ }^{506}$ Later, in his rebuke of Job, God asks rhetorically, "Have you entered into the springs of the sea, or walked in the recesses of the deep?"507 The author of 2

\footnotetext{
${ }^{504}$ Goldstein, II Maccabees, 260-261, notes that the punishment of a king who contends with the gods (the theomachos) is a common preoccupation of Greek and Jewish literature (citing, in addition to Isa 14:13-14 and 37:24-25, the stories of Xerxes in Aeschylus Persians 69-72, 744-751 and Herodotus Histories 7.22-24). The author of 2 Maccabees has used this tradition to shape his presentation of Antiochus throughout chs 5-9, making the motif explicit by characterization of the king's activity as $\theta \in о \mu \alpha \chi \epsilon \hat{\imath} \nu$ at 7:19.

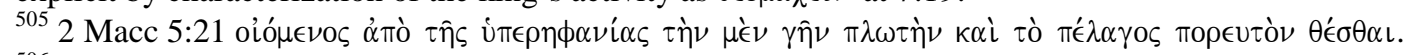

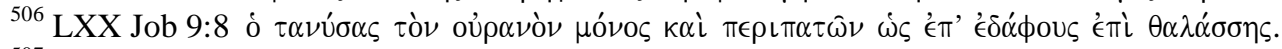

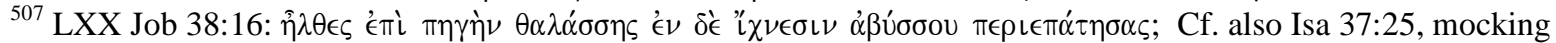
the pretentions of Sennacherib, "you have said, 'I dried up with the sole of my foot all the streams of Egypt"' (LXX "I have dried up the waters and every pool of water"); and Hab 3:15, "you trampled the sea with your horses" (LXX

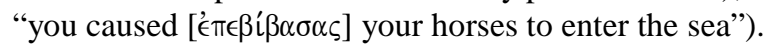


Maccabees uses stock imagery for designating the unique power and prerogative of God over the creation to depict the extreme arrogance of the Seleucid king.

Later, when God afflicts the king with a wasting disease the author delights to highlight the irony:

Thus he who only a little while before had thought in his superhuman arrogance that he could command the waves of the sea, and had imagined that he could place the high mountains in a balance, was brought down to earth and carried in a litter, making the power of God manifest to all. $^{508}$

Here, again, though evidently not borrowing from any one source, the author draws from the Biblical imagery of God's supreme command and mastery over the some of the greatest elements of nature: the sea and the mountains. ${ }^{509}$ In this vivid manner he depicts the divine pretentions of Antiochus. ${ }^{510}$

Finally, it is the climax of this motif, the words spoken by the king from his death bed, that some commentators believe to be echoed at John 10:33:

And when he could not endure his own stench, he uttered these words, "It is right to be subject

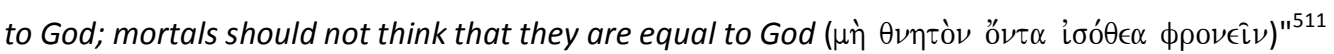

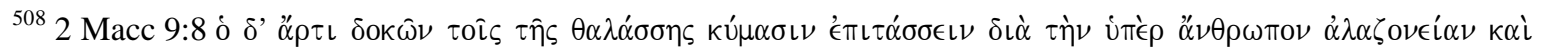

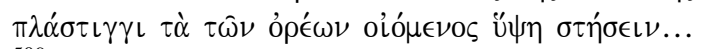

${ }^{509}$ The imagery of commanding the sea is associated with the primeval work of creation in which God established the boundaries of the seas (Job 38:8-11; Pro 8:29; Prayer of Manasseh 1:3; 4 Esdr 6:42; cf. Jer 5:22; Job 9:7-8) as well as with the parting of the Red Sea (cf. Ps 106:9). The image can also be used in general terms for the sovereign dominion of God over his creation, often carrying the implication of his ability to save his people (Ps 89:9; 93:4; 95:5107:25, 29; Isa 50:2; 51:15; Amos 5:8; Jon 1:4; Nah 1:4; Job 26:12). The image of weighing mountains in scales occurs in the LXX only at Isa 40:12 ("Who has put the

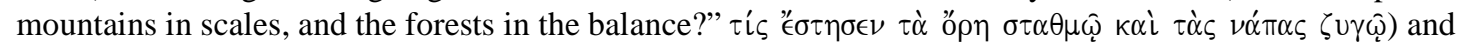
Wis 11:22 ("Because the whole world before thee is like a speck that tips the scales" [ $\pi \lambda \alpha \sigma \tau i \gamma \gamma \omega \nu]$ ). For the more general idea of God commanding and overwhelming mountains generally, see Ps 95:4; 97:5; 104:32; 114:4, 6; 144:5; Isa 2:14; 5:25; 64:1, 3; Nah 1:5; Hab 3:6, 10.

${ }^{510}$ Cf. Tobias Nicklaus, "Der Historiker als Erzahler zur Zeichnung des Seleukidenkonigs Antiochus in 2 Makk IX," VT 52 (2002) 85: "So macht der Erzähler, ohne es direkt aussprechen zu müssen, deutlich, worin die $\alpha \lambda \alpha \zeta$ oveía des Königs besteht: in der Anmaßung grenzenloser Macht und damit letztlich der Vorstellung, Gott gleich zu sein.” Similarly, Solomon Zeitlin, ed. The Second Book of Maccabees, with Introduction and Commentary (New York: Dropsie College, 1954), 149.

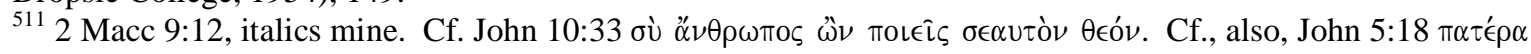

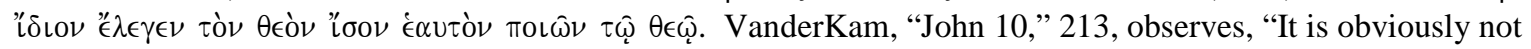
necessary to think that 2 Maccabees provides a historically reliable account of the king's last words; the anguished
} 
The author further adds to this characterization of Antiochus as a divine pretender by describing his persecution of the Jews as a "fight against God". ${ }^{512}$ In his effort to reorient Jewish worship toward himself he is guilty of nothing short of battling God himself.

The real import of this background for John, however, becomes clear only when the motif of divine pretention is set within its wider narrative framework and the resolution given the theological conflict between the pagan king and God. The narrative struggle between Antiochus and the God of Israel is resolved with reference to the works which distinguish who is truly God. The message of the author, supplied in narrative form, is that the true God is the one who displays the power to give life and to judge.

The polemic reaches a high point in the trial scene where the seven brothers are arrested and brought before the pagan king (2 Macc 7). ${ }^{513}$ The "trial" revolves around the question of whose command it is right to honor: that of Antiochus, an imposter and adversary of God (7:19), or that of the Lord. ${ }^{514}$ As the narrative unfolds, the author uses the speeches of the brothers and their mother to indicate that the God of Israel, and not Antiochus, is the true God because he has the power to give life and to judge (cf. 7:9, 11, 14, 22-23, 35-36).

God's power to give life is evoked in twofold fashion: he is the one who created the world; and he is the one who will raise the dead. ${ }^{515}$ In its immediate context, this capacity to give life refers to the hope of bodily resurrection for the brothers who died in faithfulness to the Lord. However, two factors

speech is blatantly fictitious. The important point is that this fanciful report became part of the Jewish literary heritage about King Antiochus." Along similar lines, Doran, Temple, 61, concludes that the letter highlights the "hubritic behavior" of the king that led to his punishment by God.

5122 Maccabees 7:19: $\theta \epsilon \mathrm{O} \mu \alpha \chi \in \hat{\imath} \nu$.

${ }^{513}$ This trial motif lends support to the supposition that Deut 32 and Isa 40-55 form the essential background to the author's presentation of the event, for each of these passages of Scripture make clear and rhetorically powerful use of the trial motif. In each case the singular question in the trial is whether the god(s) whose nations have subdued Israel represent true gods or whether the God of Israel is the true God. Ultimately, God demonstrates that though he briefly gave his people into the hands of the nations for discipline, yet when he acts to restore them he displays such power as proves his absolute uniqueness as the only true God. The final result is the recognition of God's uniqueness not only by Israel but by the oppressing nations who suffer God's judgment.

${ }^{514}$ Five of the ten speeches from the brothers and mother make direct reference to the "laws of the fathers" $(7: 2,9,11,23,30,37)$. The final brother (7:30) gives clear expression to this struggles between the conflicting commands: "I will not obey the king's command, but I obey the command of the law that was given to our ancestors through Moses."

${ }^{515}$ Cf. Richard Bauckham, "Life, Death, and the Afterlife in Second Temple Judaism," in Life in the Face of Death: The Resurection Message of the New Testament (ed. Richard Longenecker; Grand Rapids: Eerdmans, 1998) 85. In the appeal of the mother to her seventh and final son to "accept death", she twice reminds her son that God was the One who created the world, and all humanity, in the first place $(7: 23,28)$. What is more, "God did not make them out of things that existed" (7:28). Therefore, she reasons, her son should trust that God also has the power to "give life and breath to you again" after the son has been martyred by the king $(7: 23,29)$. Besides the mother, three of the brothers invoke God's authority to raise the dead $(7: 9,11,14)$. 
indicate that this life-giving power of God entails not only individual resurrection but national restoration from foreign oppression.

In the first place, the trial scene of 2 Macc 7 opens with the mother and remaining brothers quoting Deut 32:36 to encourage one another "to die nobly":

The LORD will vindicate his people and have compassion on his servants, when he sees that their power is gone and there is none remaining, bond or free. ${ }^{516}$

The invocation of Deut 32:36 at the outset of the trial before Antiochus in 2 Macc 7 becomes programmatic for the rest of the chapter. In a word, the resolution of the conflict between Antiochus and the God of Israel does not merely establish the abstract principle of Jewish monotheism (the God of Israel is the only true God). Rather, the resolution contributes to the transformation of divine wrath into mercy thereby bringing the liberation of the "Hebrews" ${ }^{517}$ (or at least of Jerusalem) from foreign domination. Put succinctly, God demonstrates that he alone is the true God when he acts in history to deliver his people from bondage and to judge their enemies. ${ }^{518}$

The second contextual factor that connects God's life-giving power with national restoration is that the martyrdoms of the brothers trigger the return of divine mercy prophesied in Deut 32:36. ${ }^{519}$ Following the appeal of the seventh and final brother for God to turn from wrath to mercy (2 Macc 7:3738), the immediately ensuing narrative reports the fulfillment of this appeal in the beginning of military

\footnotetext{
${ }^{516}$ The verse is quoted at 2 Macc 7:6. Within the Song of Moses, this declaration represents a key turning point in Israel's plight under divine judgment. The moment of passage from wrath to mercy, from just punishment at the hands of foreign nations to deliverance from those nations, turns on the recognition by God that the people's strength has reached a low ebb ("when he sees their strength is gone"). It is at the nadir of their suffering that God intervenes to bring restoration for the nation and judgment on their oppressors. This is the redemptive-historical context of the display of God's unique deity in verse 39: "I, even I, am he, and there is no god beside me; I kill and I make alive, I wound and I heal, and there is none that can deliver out of my hand." The prerogative to "kill and make alive" which sets God apart as unique is displayed before the nations when he turns away from wrath and shows mercy to his people.

${ }^{517}$ Cf. 2 Macc 7:31; 11:13; 15:37.

${ }^{518}$ Every bit as prominent as bodily resurrection in the hopes of the martyrs is the expectation that God will judge the king himself. After expressing his hope in the future resurrection, the fourth brother warns the king "but for you there will be no resurrection to life" (7:14). Similarly, the fifth brother taunts, "keep on and see how [God's] mighty power will torture you and your descendants" (7:17). The sixth brother, too, avers, "Do not think that you will go unpunished for having tried to fight against God" (7:19). At the climax of the story, the seventh brother delivers the most forceful and extended pronouncement of the certainty of "judgment by the almighty, all-seeing God" (7:31, 3437). Thus, in artful, ironic fashion the king who renders unjust judgment against the "children of heaven" will shortly come under the "just punishment" of God, the true judge. The Fourth Gospel employs a similar narrative pattern across John 9-10: the leaders of Israel presume to pass judgment upon Jesus, and in the end it is they who come under his judgment.

${ }^{519}$ I will not treat the issue of the role of the brothers' deaths in this process since it lies outside the scope of our concern, here.
} 
victory under Judas Maccabeus against the Seleucids (cf. 8:5, 12, 27). In this way it is evident that not only bodily resurrection but national restoration from foreign oppression are bound up with the lifegiving work of God.

One final feature of the narrative portrayal of the conflict between Antiochus and God must be highlighted for its bearing on Hanukkah. The author links the struggle for recognition of worthiness of worship to the festival of Hanukkah by re-positioning the account of Antiochus' demise from after the purification of the Temple and later military victories by Judas (as in 1 Maccabees) to immediately before the Temple cleansing and institution of Hanukkah (2 Macc 9). ${ }^{520}$ Furthermore, twin references to the death of Antiochus frame the account of the Temple's purification and the institution of Hanukkah:

${ }^{520}$ Goldstein, II Maccabees, 345-348, details the evidence that 2 Macc 10:1-8 was originally located elsewhere in
the narrative and has been re-placed in its current position by the epitomist. Goldstein struggles to account for the
rough transition from 9:29 to 10:1 as well as the "anomalous position of 10:9" which he assumes ought to have more
naturally followed immediately after 9:29. I suggest these literary features are best explained in terms of the
author's thematic purposes. The epitomist created a literary frame around 10:1-8 by twin references to the demise of
the king (9:28/10:9) in order to foster a thematic correlation between the death of the king and the restoration of
Temple worship. (Doran, Temple, 61-63, noting the linkage between the two accounts formed by the $\mu \grave{\epsilon} \nu$ oûv... $\delta \hat{\epsilon}$
construction in 9:28-10:1, comes to a similar conclusion.) This correlation suits well the author's concern to
characterize the festival of Hanukkah as an enacted petition for God to continue the deliverance of the nation begun
in the days of Antiochus IV (cf. 2 Macc 2:16-18). For the epitomist, the festival is not simply about the recovery of the Temple, but about the wider national restoration first set in motion by the seven brothers and of which the judgment of Antiochus and recovery of the Temple were but early tokens.

An earlier generation of scholars viewed the historical value of 2 Maccabees as inferior to that of 1 Maccabees. Representative is M.B. Dagut, "II Maccabees and the Death of Antiochus IV Epiphanes," JBL 72 (1953) 151, who concludes his analysis of the chronologies of 1 and 2 Maccabees by observing, "From all this it should be obvious that the few and uncertain dates of II Macc cannot be treated as on a par with the orderly evidence of I Macc.... Whatever may be the historical value of some of the material contained in II Macc, its dates cannot be regarded as reliable" (151). More recent scholarship suggests 2 Maccabees possesses comparable historical value to 1 Maccabees. See the recent review of the evidence for the historical reliability of both works in Williams, "2 Maccabees" (and the literature there cited), as well as the study of the accounts of the military campaigns of Judas Maccabeus in 1 and 2 Maccabees by Victor L. Parker, "Judas Maccabaeus' Campaigns against Timothy," Bib 87 (2006) 457-476. In another recent study, Daniel R. Schwartz, "Antiochus IV Epiphanes in Jerusalem," in Historical Perspectives: From the Hasmoneans to Bar Kokhba in Light of the Dead Sea Scrolls (ed. David Goodblatt; Studies on the Texts of the Desert of Judah, 37. Leiden: Brill, 2001) 45-56, argues persuasively that 2 Macc 5, rather than 1 Macc 1, preserves the more accurate chronology of the invasions of Jerusalem by the Seleucid king. All of this suggests it is probably best to assign greater historical reliability to 2 Maccabees than has sometimes been done, while also noting the strongly reflective and didactic character of the work (Attridge, "2 Maccabees," 181-182). Such a mediating position is represented by Van Henten, Martyrs, 24-25, who argues that the close correspondence of the historical sections of 2 Maccabees to the "reflective sections" (e.g., 4:17; 5:17-20; 6:12-17) "implies that the revision of the epitomist [to the work of Jason of Cyrene] must have been considerable. He seems to have aimed for a history which entertained and uplifted the reader by means of anecdotal and didactic historiography. He did not focus on an accurate reproduction of the events, but on the significance of these crucial events of the past for contemporary Jewish politics, religion, morality and self-understanding." Along similar lines, see Nicklaus, "Historiker", 80; Elias Bickerman, The God of the Maccabees: Studies on the Meaning and Origin of the Maccabean Revolt (Studies in Judaism in Late Antiquity; Leiden: E.J. Brill, 1979), 95-96; and M. Delcor, "The Apocrypha and Pseudepigrapha of the Hellenistic Period," in The Cambridge History of Judaism II The Hellenistic Age (eds. W.D. Davies and L. Finkelstein; Cambridge: Cambridge University Press, 1989) 465-466, who describes 
2 Macc 9:28-29 So the murderer and blasphemer, having endured the more intense suffering, such as he had inflicted on others, came to the end of his life by a most pitiable fate, among the mountains in a strange land. And Philip, one of his courtiers, took his body home...

2 Macc 10:1-8 Now Maccabeus and his followers, the Lord leading them on, recovered the temple and the city...[account of Temple's purification and institution of Hanukkah]

2 Macc 10:9 Such then was the end of Antiochus, who was called Epiphanes.

Both of the references to Antiochus' death imply his claim to divinity. The label "the blasphemer" (9:28) refers to his "arrogance" in thinking himself to be equal with God. The second of the references to Antiochus' death closes with express reference to the blasphemous title, Epiphanes

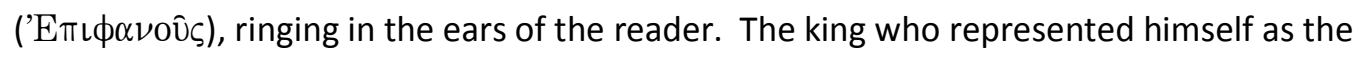
"manifestation" of god, died under judgment by the true God.

The whole shape of the narrative of 2 Macc 5-10, with its many signals of the blasphemous nature of Antiochus' usurpation of divine worship, its relocation of the account of the king's demise, and its twin references to his death framing the account of the institution of Hanukkah, imbue the festival of Hanukkah with a deeper meaning than merely the re-commencing of Temple worship after a period of cessation (as in Josephus). By a creative and artful reworking of the whole narrative, the author invests the celebration with significance for monotheistic worship. In a sense, Hanukkah becomes a celebration of the Shema in eschatological perspective: the universal recognition that the God of Israel is uniquely worthy of worship. ${ }^{521}$

In the Hanukkah tradition represented by 2 Maccabees the uniquely divine works of giving life and judging set God apart from Antiochus as the one true God. Antiochus believed himself to be god

the style of the epitomist as "history with feeling". I would suggest, modifying the statement of Van Henten above, the epitomist did "focus on an accurate reproduction of the events" but exercised some freedom in the ordering and shaping of the account so as more clearly to bring out "the significance of these crucial events of the past for contemporary Jewish politics, religion, morality and self-understanding." In this regard, the aims and method of the epitomist of 2 Maccabees resemble those of the Biblical Gospel writers.

521 cf. esp. 2 Macc 7:37 and 9:12; also, 5:17,21; 7:16,19; 9:8,10. The same pattern of false (blasphemous) selfconception by a pagan king followed by prayer by his Jewish victims for his "enlightening" followed finally by the king's recognition of the uniqueness of the God who delivers his servants is observable in LXX Dan 3 (cf. 3:1, 45, 95-96). Both 2 Macc and LXX Dan 3:45 (= Prayer of Azariah 22) likely draw from the flow of thought in Deut 32 culminating in the recognition by the nations of God's uniqueness (32:27-30, 39). 
"manifest". He viewed himself in divine terms and so required sacrifices be made to him on his birthday every month. Yet, the author pronounces his verdict in narrative form against the pretensions of Antiochus. For ultimately, God, not Antiochus, gives life to the people when he delivers them from the foreign armies thereby showing the "beginning of mercy" (2 Macc 8), the eschatological deliverance of Deut 32:36. Furthermore, God, not Antiochus, displays his power in rendering judgment when he afflicts the king with a fatal disease (2 Macc 9). It is these works of national redemption performed by God which form the basis of the celebration that would become known as Hanukkah (2 Macc 10). In the end, therefore, the pagan king himself confesses, "It is right to be subject to God; mortals should not think that they are equal to God." ${ }^{522}$ Antiochus is not "equal to God", for God alone gives life and judges and is therefore worthy of worship.

\section{Application to John 10}

John may well be tapping into this tradition to make a bold counter-implication to the implication of the Jews in 10:33. By applying to Jesus the language of blasphemy and a mortal making himself God, the Jews raise the specter of Antiochus and insinuate that Jesus is guilty of the same blasphemy as the Seleucid king. While a number of commentators have recognized the likely allusion to this background, ${ }^{523}$ what has not been noted is the likelihood that the threefold appeal to Jesus' works $(10: 25,32,37-38)$ represents an ironic counter-assertion which draws on this same tradition.

Since John 5:19-30, the "works" God gave Jesus to do and which Jesus has "shown" the Jews are giving life and judging, the very works by which God distinguished himself from Antiochus as the unique God who alone is worthy of worship. Jesus' performance of them, therefore, demonstrates that he shares in the identity of Israel's God.

The Hanukkah background suggests that two implications likely follow from this conclusion. First, the life-giving work Jesus does to demonstrate his identity with God is nothing short of national restoration. We have seen that there is more than abstract monotheism at play in the anti-Antiochus polemic of 2 Maccabees. The life-giving work which sets God apart from the imposter entails both the resurrection of the faithful dead as well as the ingathering of the scattered people of the nation. The life

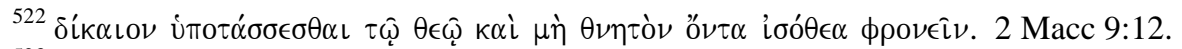

${ }^{523}$ For example, VanderKam, "John 10," 213: "Jesus' unbelieving audience who do not belong to his sheep see in the divine Son only another blasphemer who, like the Seleucid king, claimed to be god." Cf. Keener, John, 827; Moloney, Signs, 149 n.22; Kerr, Temple, 252 and n.135; Coloe, Dwells, 149. Schnackenburg, John, 2.309, believes

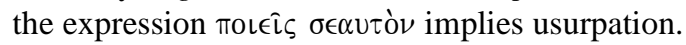


God gives is both resurrection and the fullness of eschatological restoration from exile. ${ }^{524}$ This accords very well with the nature of life Jesus gives throughout John 5-10 where both these dimensions are in view. On the one hand, "life" is repeatedly defined in terms of resurrection from the dead (e.g., John $5: 24-25,28-29 ; 6: 39,40,44,54 ;$ cf. 11:25-26). On the other hand, life also entails the restoration of the nation (cf. the gathering of the scattered children of God in John 10:16). ${ }^{525}$ Thus, as with God in 2 Maccabees, Jesus' display of his unique deity in life-giving works will effect the gathering of the nation from exile. ${ }^{526}$

It may be appropriate to recall, here, that at least one stream of Jewish tradition (represented by 2 Maccabees) probably viewed the celebration of Hanukkah as an enacted petition for God to restore the nation. Indeed, the final shape of 2 Maccabees suggests that the festival represented an annual renewal of the plea for God to bring to completion the restorational mercy set in motion in the deliverance from Antiochus. In this way Jesus answers the implicit petition for restoration associated with the festival of Hanukkah. He does this by fulfilling the expectation and hope for the gathering of the dispersed people of God and judgment on their enemies.

A third observation follows from the Maccabean background. The gathering of the nation hoped for in 2 Maccabees is a gathering unto renewed worship of the true God. The wider Hanukkah tradition evinced in 1 Maccabees and Josephus emphasizes the renewal of Temple worship. However, 2 Maccabees adds the additional dimension of the uniqueness of Israel's God as the only one worthy of worship. This orientation of the narrative in 2 Maccabees forges a striking link between the restoration of Temple worship and the monotheistic faith of Israel. Part of the meaning of Hanukkah was the expectation of future recognition by Jew and Gentile alike that Israel's God is the one and only true God in all the world. ${ }^{527}$ Insofar as they seek restoration, it is to worship of the one true God that they seek to be restored.

\footnotetext{
${ }^{524}$ This is why the second letter which opens 2 Maccabees petitions its readers to observe the festival which celebrates this deliverance: so that God might be moved to bring to completion the national restoration begun in the days of the Maccabees. See esp. reference to this "gathering" at 2 Macc 1:24-29 and 2:9, 18.

${ }_{525}$ On this, see especially Dennis, Gathering, 200-201, 293-302; Manning, Echoes, 125-127; Andrew Lincoln, "I Am the Resurrection and the Life: The Resurrection Message of the Fourth Gospel," in Life in the Face of Death: The Resurection Message of the New Testament (ed. Richard Longenecker; Grand Rapids: Eerdmans, 1998) 128. ${ }_{526}^{527}$ Of course, this idea occurs prominently in the surrounding context (cf. 10:16 and 11:47-53).

${ }^{527}$ The "knowledge" motif in 2 Maccabees is not confined to the knowledge of Antiochus but includes the (right) knowledge of the Jews, as well. Hence, the seven brothers recognize that it is God, "the King of the Universe", who alone has authority to judge his enemies (cf. 7:16, 18-19,37) and give life both the nation as a whole and to individuals through resurrection of their bodies (cf. 7:22-23, 28-29). Cf. also 2 Macc 1:27 where the people's prayer under Nehemiah seeks national ingathering with a view toward Gentile knowledge "that you are our God."
} 
Against this backdrop, John 10:22-39 should not be read as though it stopped at identifying Jesus with God. The Hanukkah traditions I have examined suggest a further implication. The goal of this revelation is the "knowledge" of Jesus" unique deity (cf. " $\nu \alpha \gamma \nu \omega \hat{\omega} \tau \epsilon, v .38$ ) and by implication his consequent worthiness of worship. Once again, such implications from the Hanukkah background fit very neatly in the larger narrative setting of John 5-10. John 5 made clear not only that by doing the works of God Jesus "makes himself equal with God", but that God's purpose in this was that "all might honor the son just as they honor the Father" (5:23). Symbolic fulfillment of this goal comes at the climax of the narrative of the blind man in chapter 9 when Jesus becomes the object of worship. ${ }^{528}$ This narrative illustrating the worship of Jesus as the end-goal of his works immediately precedes and leads into John 10. For this reason, while John 10:22-39 does not make explicit mention of worship, yet the narrative context already links Jesus' works with worship of his person. In the interpretation of the Hanukkah tradition in 2 Maccabees God "manifested" his unique power to give life and judge with a view to restoring Temple worship and redirecting it from the blasphemous Seleucid king to the only true God. John picks up on this tradition in his portrayal of Jesus at the climax of the public ministry. In a word, it is unto worship of Jesus as the one true God that Jesus "manifests" his deity when he effects national restoration by giving life and judging.

\section{E. Conclusion}

I conclude by observing, once again, the way in which John draws Jesus into the symbolism and traditions central to the Jewish feast in order to depict his work of salvation as the eschatological realization of all that was signified by the festival. Jesus does not debase Dedication as flawed or failed nor does he set it aside in order to supersede it. Rather he clothes his work with the traditions at the core of the festival and so reveals that his work represents the enactment of the eschatological deliverance petitioned for by those who celebrated the festival.

\footnotetext{
${ }^{528}$ John 9:38.
} 


\section{Chapter 6}

\section{Conclusion}

\section{A. Summary of findings}

The foregoing study has sought to illumine the use of the Jewish festivals in the Fourth Gospel with a view toward sharpening and elaborating contemporary understanding of their thematic import for the presentation of Jesus in the Gospel. More specifically, I have examined the symbolism, customs and traditions surrounding the feasts in second Temple times together with the narrative contexts in which they appear in John in order to gain a more accurate and precise understanding of how the author has appropriated them for his message. Each of these festivals was associated in one way or another with the expectation and hope of national restoration, and the author has tapped into this collective hope to represent Jesus as effecting the restoration of the nation. More than this, however, the real innovation of the author lies in the way in which he appropriates distinctive features of each festival to illumine both the content of the salvation Jesus achieves as well as the manner in which he brings it about.

Beginning with Passover, I argued that John placed the bulk of his emphasis on the symbolic import of the pascal meal rather than upon any notion of the pascal sacrifice as effecting substitutionary atonement. In Jewish tradition, participation in the Passover meal centered on the eating of the pascal lamb and was linked with one's participation in the community of God's people. In $1 \mathrm{Chr} 30$, for example, to have refused the invitation of king Hezekiah to come to Jerusalem to join in the Passover celebration would have been tantamount to refusing to join the newly reconstituted covenant community. This symbolism receives essential exposition in John 6 where the salvation Jesus effects is identified with the Isaianic restoration of the nation (the new exodus), and participation in this restored community of God's people comes about through partaking of the pascal meal, that is, by eating the flesh of Jesus, the pascal lamb.

Turning next to the festival of Tabernacles, I argued that the author draws upon the central customs of the festival to depict this new exodus salvation Jesus brings as a latter-day Meribah provision. The words of Jesus appear to hearken to the water, willow and palm ceremonies that revolved around the Temple altar and in this way may invite the association of Jesus with the Temple altar. This reading finds support in the composite citation at 7:38 where eschatological Temple traditions (esp. Ezek 47 and Zec 14) are conflated with the wilderness rock tradition of Ps 78. These 
symbolic and traditional backgrounds may hint that, like the rock in the wilderness, this altar (Jesus) must be struck to provide the life-giving water for the people.

Finally, John employed the festival of Dedication for the backdrop to the climactic confrontation between Jesus and the Jewish authorities in his public ministry. He drew Jesus into the heart of the thematic traditions of this festival by recalling the confrontation between Antiochus IV Epiphanes and the God of Israel. 2 Maccabees depicts the resolution of this confrontation as a kind of eschatological enactment of the shema: the God of Israel shows that he, rather than Antiochus, is the one true God worthy of worship when he effects the national restoration of Deut 32:36 by giving life and judging. As 2 Maccabees links the celebration of Dedication with the hope that God would bring to completion the restoration he (seemingly) began under Judas Maccabeus, so Jesus indicates that he fulfills these restorational hopes in the "works" the Father gave him to do. So far from being the latter-day incarnation of Antiochus that the leaders allege, Jesus brings the fullness of national redemption as he gives life and judges, and by this means he shows that he is the one true God of Israel uniquely worthy of worship.

\section{B. Conclusion}

The burden of this study has been the further elucidation of the role of the Jewish feasts in John's Gospel. Nevertheless, I wish to conclude by suggesting three points at which my analysis makes important contributions to wider concerns in contemporary Johannine scholarship. The first point is one which has been a prominent, even if secondary, concern throughout this study: namely, the wider issue of Judaism in the Fourth Gospel. In my second chapter, on Judaism in John's Gospel, I argued that John regards the institutions of the Jewish religion as living prophecies which prepare for and point ahead to the eschatological salvation fully revealed in Jesus. My analysis of the Jewish feasts has, I hope, born this out. Jesus evokes both Old Testament and contemporary traditions and symbolism surrounding these three festivals in order to set forth his work as the full flowering of that which is signified by the feasts. In each instance, Jesus enters into the heart of festal symbolism to communicate the meaning of his salvation.

John's use of the Jewish feasts, then, undermines the common characterization of Judaism in the Fourth Gospel in terms of judgment or rejection, as well as of replacement or supersession. Each of these descriptors represents the relationship between Jesus and Judaism in essentially negative terms. Yet John, I have argued, never represents the Jewish religion in a negative light as having failed or as flawed and in need of replacement. Beyond manifest negative connotations, however, such 
descriptions fail adequately to capture the true nature of the relationship between Judaism and Jesus. For John, the institutions of Judaism serve a definite divine purpose and do so legitimately and effectively. They function as living prophecies pointing to the eschatological salvation of Jesus. The coming of Jesus, therefore, witnesses not the casting aside of Judaism but the "filling up to the top" of its various institutions. Rather than speaking about the replacement of Judaism, it is more accurate, ultimately, to speak of the portrayal of Jesus in the Fourth Gospel as the eschatological goal and apex of Temple worship and thus climax of Jewish religion.

The second point at which my investigation has made an important contribution is in showing the way in which the feasts contribute to John's presentation of the divine identity of Jesus. Recent scholarship on New Testament Christology has struggled to define the parameters within which the authors of the New Testament conceived of the divinity of Jesus. Richard Bauckham has sought to move the discussion in a new direction by proposing that Jesus is understood not in ontological terms as possessing a divine nature, nor as divine in the same way as angelic figures were conceived of in some quarters of second Temple Judaism. Rather, the divinity of Jesus was conceived of in terms of the divine identity. Specifically, Jesus is presented as sharing in the identity of the one, true God of Israel. ${ }^{529} \mathrm{My}$ investigation of the role of the Jewish feasts in the Fourth Gospel furnishes additional evidence for this line of thought.

In John's use of Passover he interpreted the Passover tradition not only through the lens of the new exodus hope of Isa 40-55, but also through the lens of the wilderness traditions represented by Ps 78 and Num 11. Both of these backgrounds were invoked for the purpose of casting Jesus in the role of Yahweh in his unique ability to provide life-giving food for the people. The provision made by Jesus, the pascal lamb, not only accomplishes the restoration of the nation for which pilgrims at the annual festival longed, but also displays the divine identity of Jesus who provides what only God can for his people.

My investigation of Tabernacles revealed that here, too, the divine identity of Jesus is in evidence. I argued that John 7:32-37 contains an allusion to the divine summons of Isa 55 to the eschatological feast. John turns the seeking motif that spans chapters 7-8 to important use by placing Jesus in the role of Yahweh urging his listeners to "come to him" for the water that gives life. Following hard on this allusion is, of course, the pivotal citation of Scripture in John 7:38. Drawing upon the wilderness tradition represented, chiefly, by Ps 78 as well as the eschatological Temple prophecies of Ezek 47 and Zec 14 John probably associates Jesus with the Temple altar which, according early Rabbinic sources, was associated in Tabernacles with both the wilderness rock and with Yahweh who "stood

${ }^{529}$ See Bauckham, God Crucified; and idem., "Monotheism". 
upon the rock" when it was struck. Thus, here again, as in his use of Passover John does not simply represent Jesus as bringing to fulfillment the salvation prefigured in the symbolism of Tabernacles, he also portrays Jesus as doing so in such a way as to display his unique divine identity.

The use to which the final feast is put in the Fourth Gospel gives the most pronounced expression to this point. Drawing from the traditions of the blasphemy of Antiochus IV and martyrdoms of the seven brothers in 2 Maccabees, John depicts the climactic encounter between Jesus and the Jewish leaders as a struggle over the question of Jesus' identity, and one which turns chiefly on the works Jesus does. The Jewish leaders insinuated that Jesus' claim to be the "son of God" was blasphemy on the order of that of the pagan oppressor whose defeat by the Maccabees gave rise to the festival of Dedication. In response, Jesus directed their attention to the works he was performing (recounted across John 5-10), for these works, the works of giving life and judging, are the quintessential works of God. By these works God shows that he alone is the true God and alone worthy of Israel's worship. Thus, in his appropriation of the final feast, the Feast of Dedication, John does not simply represent Jesus as the fulfillment of the eschatological hopes of Israel for full restoration. He also represents Jesus as making a display of his identity as the one true God of Israel in the very accomplishment of this salvation and, therefore, as uniquely worthy of the people's worship.

Closely related to Johannine Christology, of course, is soteriology, and so it is possible to derive insight into the teaching about salvation in the Fourth Gospel from the above observations about the person of Jesus. In a word, the basic focus of salvation in John is Jesus and the crucial importance of entering into an intimate relationship with his person. This emphasis is evident in the use of Passover symbolism where I argued the focus lies not upon atonement theology but upon the means by which an individual enters into the redeemed covenant community. The atoning value of the death of Jesus is evident in John's use of Isa 53 at several points of the Gospel narrative. Of greater interest to the author, however, is the powerful symbolism surrounding the eating of the pascal meal and its function in expressing solidarity with the renewed people of God. John applies to Jesus the imagery of the sacrificial lamb of Passover in order to emphasize the fundamental importance of entering into direct, intimate relationship with Jesus and so to participate in the redeemed community.

The same basic emphasis emerges in the Gospel's use of the feasts of Tabernacles and Dedication. Against the backdrop of the former feast, John symbolically claims that to benefit from the new exodus salvation wrought by Jesus one must "come" to Jesus and "drink" the "living water" which he alone provides. Similarly, the import of the climactic narrative in John 10:22-39 set during Dedication is that the national restoration brought about by Jesus has as its ultimate goal the worship of Jesus as 
the one, true God of Israel. Once more, then, salvation is oriented toward relationship with Jesus. In a word, the use made of the Jewish festivals indicates that if Johannine Christology reveals the divine identity of Jesus, Johannine soteriology is largely a matter of entry into personal relationship with this Jesus.

Finally, the foregoing study sheds additional light on discussions of the Johannine Sitz im Leben. A growing consensus regards John's Gospel as composed in the context of, and perhaps in direct response to, the destruction of the Temple in 70 C.E.. ${ }^{530}$ This stands in stark contrast to the near total neglect of this dimension of post-70 C.E. Jewish experience in Johannine scholarship of earlier generations. Stephen Motyer decries what he calls the "de-historicizing of John" among earlier commentators from Bultmann to Schnackenburg and Brown as well as in monographs devoted to the social setting of the Fourth Gospel from this same period. ${ }^{531}$ Taking Schnakenburg's treatment of Jesus' saying about the destruction of the Temple in John 2:12-22 as an example, Motyer observes, "Conspicuous by its absence is any interest in the function of this story in the post-70 situation, when 'destroy this Temple' has become a horrible reality - even though this is the very period in which Schnackenburg dates the Gospel.."532

Representative of more recent scholarship that regards the destruction of the Temple as the primary facet of the Johannine Sitz im Leben, however, Motyer goes on to propose,

Indeed, so poignant and powerful would this story be for those who had faced the trauma of the Jewish war, that this is in itself an argument for setting the Gospel in that situation. We could well find the reason for the prominence given to this story, and then to the festivals, in the evangelist's desire to address this trauma. ${ }^{533}$

With regard to the festivals, specifically, he concludes, "The use of imagery drawn from the festivals throughout [John 5-10] creates its own irony, inevitably reminding readers of what they have lost, and of their need to find something to fill the gap." ${ }^{2534}$

The results of my investigation lend considerable support to this reading of the influence of the destruction of the Temple on the shape and goals of the Gospel. I have argued in the case of each festival that the expectation of national restoration associated with the Temple celebration finds its

\footnotetext{
${ }^{530}$ See the helpful survey of scholarship on this question in Köstenberger, "Destruction", 221-227.

${ }^{531}$ Motyer, Father, 36-39, citing Whitacre, Polemic, and Neyrey, Revolt.

${ }^{532}$ Motyer, Father, 39. Cf. Köstenberger, "Destruction”, 228.

${ }^{533}$ Motyer, Father, 39.

${ }^{534}$ Motyer, Father, 125. Again, cf. Cf. Köstenberger, "Destruction”, 228-231, 236-238.
} 
ultimate realization in the work of Jesus. Such a presentation of Jesus fits very naturally with the social context of the absence of the Temple and the inevitable hope for national restoration. Where my work is particularly noteworthy, along these lines, is in its findings in regard to the identity of Jesus as the one, true God of Israel. All three festival narratives in John lead the reader toward the conclusion that the restoration of the nation, which the prophets foretold and for which pilgrims at the feasts hoped, has as its highest goal the worship of Jesus as the God of Israel. Admittedly, this conclusion is clearest in the final feast, the feast of Dedication. Nevertheless, each festival context in the Gospel gives evidence of the author's concern to present Jesus as sharing in the identity of Israel's God. This conclusion furnishes important corroborative evidence for the contention of Köstenberger that John portrays Jesus as the new locus of worship in the absence of the Jerusalem Temple. ${ }^{535}$ Whereas Köstenberger draws this conclusion from his examination of John 4 and 9, I have shown that the festival contexts evince the same theological orientation.

${ }^{535}$ Köstenberger, "Destruction”, 228-229, 238-239. 


\section{Bibliography}

Albright, William Foxwell. Archaeology and the Religion of Israel, Ayer Lectures of the Colgate-Rochester Divinity School, 1941. Baltimore: The Johns Hopkins Press, 1953.

Albright, William Foxwell. "The Babylonian Temple-Tower and the Altar of Burnt-Offering." Journal of Biblical Literature 39 (1920): 137-142.

Allison, D. "The living water (John 4:10-14, 6:35c, 7:37-39)." St Vladimir's Theological Quarterly 30 (1986): 143-157.

Anderson, Bernard W. "Exodus Typology in Second Isaiah." Pages 177-195 in Israel's Prophetic Heritage: Essays in Honor of James Muilenburg. Edited by Bernard W. Anderson. London: SCM, 1962.

Ashby, Godfrey W. "Body and Blood in John 6:41-65." Neotestamentica 36 (2002): 57-61.

Ashby, Godfrey W. Sacrifice: Its Nature and Purpose. London: SCM Press, 1988.

Ashton, John. "The Identity and Function of the Ioudaioi in the Fourth Gospel." Novum Testamentum 27 (1985): 40-75.

Attridge, Harold. "2 Maccabees." Pages 176-183 in Jewish Writings of the Second Temple Period: Apocrypha, Pseudepigrapha, Qumran, Sectarian Writings, Philo, Josephus. Compendia Rerum Iudaicarum Ad Novum Testamentum. Edited by M.E. Stone. Philadelphia: Fortress, 1984.

Audet, J.P. "La soif, l'eau et la parole." Revue Biblique 66 (1959): 379-86.

Balabanski, V. "'Let anyone who is thirsty come to me': John 7:37-38 in dialogue with Josephus and the archaeology of aqueducts." Lutheran Theological Journal 39 (2005): 132-139.

Balfour, G. "The Jewishness of John's Use of the Scriptures in John 6:31 and 7:37-38." Tyndale Bulletin 46 (1995): 357-380.

Barrett, C. K. The Gospel According to St. John: An Introduction with Commentary and Notes on the Greek Text. 2nd ed. Philadelphia: Westminster Press, 1978.

Barrett, C. K. "The Old Testament in the Fourth Gospel." Journal of Theological Studies 48 (1947): 155169.

Barrett, C. K. “The Lamb of God.” New Testament Studies 1 (1954-1955): 210-218.

Bauckham, Richard. "Life, Death, and the Afterlife in Second Temple Judaism." Pages 80-98 in Life in the Face of Death: The Resurection Message of the New Testament. Edited by Richard Longenecker. Grand Rapids: Eerdmans, 1998.

Bauckham, Richard. "Messianism According to the Gospel of John." Pages 34-68 in Challenging Perspectives on the Gospel of John. Edited by John Lierman. WUNT 219, Tübingen: Mohr, 2006. 
Bauckham, Richard. "Monotheism and Christology in the Gospel of John." Pages 148-166 in Contours of Christology in the New Testament. Edited by Richard N. Longenecker. Grand Rapids: Eerdmans, 2005.

Bauckham, Richard. God Crucified: Monotheism and Christology in the New Testament, The Didsbury Lecture Series, 1996. Carlisle: Paternoster, 1998.

Bauckham, Richard. "The Holiness of Jesus and his Disciples in the Gospel of John." Pages 253-269 in Testimony of the Beloved Disciple: Narrative, History and Theology in the Gospel of John. Edited by Richard Bauckham. Grand Rapids: Baker Academic, 2007.

Baumgarten, Joseph M. "A New Qumran Substitute for the Divine Name and Mishnah Sukkah 4.5." Jewish Quarterly Review 83 (1992): 1-5.

Baumgarten, Joseph M. "4Q500 and the Ancient Conception of the Lord's Vineyard." Journal of Jewish Studies 40 (1989): 1-6.

Beasley-Murray, George R. John. Word Biblical Commentary, v.36. Waco, Texas: Word Books, 1987.

Becker, Jürgen. Das Evangelium nach Johannes. Gütersloh: Echter Verlag; Würzburg: Gütersloher Verlagshaus Mohn, 1979-1981.

Beetham, F.G. and P.A. Beetham. "A Note on John 19:29." Journal of Theological Studies 44 (1993): 163169.

Begg, Christopher T. and Paul Spilsbury. Flavius Josephus: Translation and Commentary Vol. 5: Judean Antiquities Bks 8-10. Leiden: Brill, 2005.

Bennema, Cornelis. Excavating John's Gospel: A Commentary for Today. Bangalore: ISPCK, 2005.

Bernard, John Henry. A Critical and Exegetical Commentary on the Gospel According to St. John. The International Critical Commentary. Edinburgh: Clark, 1928.

Beutler, Johannes. "Greeks Come to See Jesus (John 12,20f)." Biblica 71 (1990): 333-347.

Beutler, Johannes. Judaism and the Jews in the Gospel of John. Subsidia Biblica; Roma: Editrice Pontificio Istituto Biblico, 2006.

Beutler, Johannes. "The Use of 'Scripture' in the Gospel of John." Pages 147-162 in Exploring the Gospel of John: In Honor of D. Moody Smith. Edited by R. Alan Culpepper and C. Clifton Black. Louisville, Ky.: Westminster John Knox, 1996.

Bickerman, Elias. The God of the Maccabees: Studies on the Meaning and Origin of the Maccabean Revolt, Studies in Judaism in Late Antiquity. Leiden: E.J. Brill, 1979.

Bienaimé, Germain. "L'annonce des fleuves d'eau vive en Jean 7,37-39." Revue Theologique de Louvain 21 (1990): 281-310, 417-54. 
Bienaimé, Germain. Moïse et le don de l'eau dans la tradition juive ancienne: targum et midrash, Analecta biblica, no. 98. Rome: Biblical Institute Press, 1984.

Bieringer, Reimund. Didier Pollefeyt and Frédérique Vandecasteele-Vanneuville, eds., Anti-Judaism and the Fourth Gospel. Louisville: Westminster John Knox, 2001.

Blenkinsopp, Joseph. "The Quenching of Thirst: Reflections on the Utterance in the Temple, John 7:3739." Scripture 12 (1960): 39-49.

Blenkinsopp, Joseph. Ezra-Nehemiah, Old Testament Library. London: SCM, 1989.

Blomberg, Craig L. The Historical Reliability of John's Gospel. Leicester, England: Apollos, 2001.

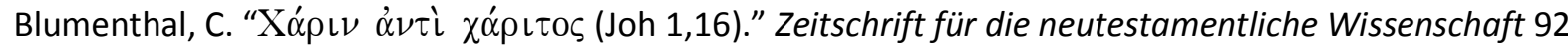
(2001): 290-294.

Boismard, Marie Emile. "De son ventre couleront des fleuves d'eau." Revue Biblique 65 (1958): 523-546.

Boismard, Marie Emile. "Les citations targumiques dans le quatrième évangile." Revue Biblique 66 (1959): 374-378.

Boismard, Marie Emile. St. John's Prologue. Translated by Carisbrooke Dominicans. London: Blackfriars, 1957.

Bokser, Baruch M. The Origins of the Seder: The Passover Rite and Early Rabbinic Judaism. Berkeley: University of California Press, 1984.

Borchert, Gerald L. John 1-11, New American Commentary. Nashville, Tenn: Broadman \& Holman, 1996.

Borchert, Gerald L. "The Passover and the Narrative Cycles in John." Pages 303-316 in Perspectives on John: Method and Interpretation in the Fourth Gospel. Edited by Robert B. Sloan and Mikeal C. Parsons. Lewiston, Maine: Edwin Mellen Press, 1993.

Borg, Marcus J. Conflict, Holiness \& Politics in the Teachings of Jesus, Studies in the Bible and Early Christianity, v. 5. Lewiston, N.Y: Edwin Mellen Press, 1984.

Borgen, Peder. "John 6: Tradition, Interpretation and Composition." Pages 95-114 in Critical Readings of John 6. Edited by R. Alan Culpepper. Leiden: Brill, 1997.

Borgen, Peder. Bread from Heaven: An Exegetical Study of the Concept of Manna in the Gospel of John and the Writings of Philo. Supplements to Novum Testamentum. Leiden: E.J. Brill, 1965.

Braun, F.-M. Jean Le Thèologien: Sa Thèologie - Le Mystère de Jèsus-Christ - Vol. III, Études Bibliques. Paris, 1966.

Brewer, David Instone. Techniques and Assumptions in Jewish Exegesis before 70 CE. Texte Und Studien Zum Antiken Judentum. Tübingen: Mohr, 1992. 
Brewer, David Instone. Feasts and Sabbaths: Passover and Atonement. Traditions of the Rabbis from the Era of the New Testament 2a. Grand Rapids, Mich: Eerdmans, 2010.

Brewer, David Instone. Feasts and Sabbaths: Sukkot. Traditions of the Rabbis from the Era of the New Testament $2 b$. Grand Rapids, Mich: Eerdmans, Forthcoming.

Brodie, Thomas L. The Gospel According to John: A Literary and Theological Commentary. New York: Oxford University Press, 1993.

Brooke, G.J. " $4 Q 500$ and the Use of Scripture in the Parable of the Vineyard." Dead Sea Discoveries 2 (1995): 268-294.

Broshi, Magen and Esther Eshel. "The Greek King is Antiochus IV (4QHistorical Text =4Q248)." Journal of Jewish Studies 48 (1997): 120-129.

Brown, Colin, ed. The New International Dictionary of New Testament Theology. 4 vols. Grand Rapids: Zondervan, 1975-1985

Brown, Raymond E. The Gospel According to John, 2 vols. Garden City, N.Y: Doubleday \& Co, 1966, 1970.

Brown, Raymond E. The Death of the Messiah: From Gethsemane to the Grave--a Commentary on the Passion Narratives in the Four Gospels. London: Geoffrey Chapman, 1994.

Brown, Tricia Gates. Spirit in the Writings of John: Johannine Pneumatology in Social-scientific Perspective. Journal for the Study of the New Testament Supplement. London: T \& T Clark, 2003.

Bruce, F. F. The Gospel of John. Grand Rapids, Mich: Eerdmans, 1983.

Brunson, Andrew C. Psalm 118 in the Gospel of John: An Intertextual Study on the New Exodus Pattern in the Theology of John. Wissenschaftliche Untersuchungen Zum Neuen Testament. Tübingen: Mohr Siebeck, 2003.

Bryan, Steven M. Jesus and Israel's Traditions of Judgement and Restoration. Society for New Testament Studies Monograph Series. Cambridge: Cambridge University Press, 2002.

Budd, Philip J. Numbers. Word Biblical Commentary. Waco: Word Books Ltd, 1984.

Bultmann, Rudolf. The Gospel of John: A Commentary. Translated by G. R. Beasley-Murray. Oxford: Blackwell, 1971.

Burge, Gary M. The Anointed Community: The Holy Spirit in the Johannine Tradition. Grand Rapids: Eerdmans, 1987.

Burkett, Delbert. The Son of the Man in the Gospel of John. Journal for the Study of the New Testament Supplement. Sheffield: JSOT Press, 1991. 
Burroughs, Presian R. "Stop Grumbling and Start Eating: Gospel Meal Meets Scriptural Spice in the Bread of Life Discourse." Horizons in Biblical Theology 28 (2006): 73-94.

Carey, G.L. "The Lamb of God and Atonement Theories." Tyndale Bulletin 32 (1981): 97-122.

Carson, D. A. The Gospel according to John. Leicester: Inter-varsity, 1991.

Carson, D. A. "John and the Johannine Epistles." Pages 245-264 in It is Written: Scripture Citing Scripture. Essays in Honor of Barnabas Lindars, SSF. Edited by D.A. Carson and H.G.M. Williamson. Cambridge: Cambridge University Press, 1988.

Chennattu, Rekha. Johannine Discipleship as a Covenant Relationship. Peabody, MA: Hendrickson, 2006.

Claussen, Carsten. "The Eucharist in John and the Didache." Pages 135-163 in Trajectories through the New Testament and the Apostolic Fathers. Edited by Andrew F. Gregory and Christopher M. Tuckett. Oxford: Oxford University Press, 2005.

Colautti, Frederico M. Passover in the Works of Josephus. Leiden: Brill, 2002.

Collins, J.J. "Sibylline Oracles." Pages 317-472 in The Old Testament Pseudepigrapha and the New Testament: Prolegomena for the Study of Christian Origins. Edited by James Hamilton Charlesworth. Society for New Testament Studies Monograph Studies; Cambridge: Cambridge University Press, 1985.

Coloe, Mary L. 'God Dwells with Us': Temple Symbolism in the Fourth Gospel. Collegeville, Minnesota: Liturgical Press, 2001.

Cook, Edward M. “4Q246.” Bulletin for Biblical Research 5 (1995): 43-66.

Cortés, J. “Yet another look at Jn 7:37-38." Catholic Biblical Quarterly 29 (1967): 75-86.

Cory, Catherine. "Wisdom's Rescue: A New Reading of the Tabernacles Discourse (John 7:1-8:59)." Journal of Biblical Literature 116 (1997): 95-116.

Cullmann, Oscar. "Samaria." Pages 185-192 in The Early Church. Edited by Oscar Cullmann. Translated and edited by A.J.B.Higgins, London : SCM Press, 1956.

Culpepper, R. Alan. Anatomy of the Fourth Gospel: A Study in Literary Design. Philadelphia: Fortress Press, 1983.

Culpepper, R. Alan. “The Pivot of John's Prologue.” New Testament Studies 27 (1980-1981): 1-31.

Cummins, Stephen Anthony. Paul and the Crucified Christ in Antioch: Maccabean Martyrdom and Galatians 1 and 2. Society for New Testament Studies Monograph Series. Cambridge, U.K: Cambridge University Press, 2001.

Dagut, M.B. "II Maccabees and the Death of Antiochus IV Epiphanes." Journal of Biblical Literature 72 (1953): 149-157. 
Dahms, John V. "Isaiah 55 and the Gospel of John." Evangelical Quarterly 53 (1981): 78-88.

Daise, M. "'If Anyone Thirsts, Let That One Come to Me and Drink':The Literary Texture of John 7:37b38a" Journal of Biblical Literature 122 (2003): 687-699.

Daise, Michael A. Feasts in John: Jewish Festivals and Jesus' "Hour" in the Fourth Gospel. WUNT; Tübingen: Mohr, 2007.

Daly, R.J. "The Soteriological Significance of the Sacrifice of Isaac." Catholic Biblical Quarterly 39 (1977): 45-75.

Daly-Denton, Margaret. David in the Fourth Gospel: The Johannine Reception of the Psalms. Leiden: Brill, 2000.

Daniélou, J. “Le symbolisme de l'eau vive.” Revue des sciences religieuses 32 (1958): 335-346.

Danielou, J. "Joh. 7,38 et Ezech. 47,1-11." Pages 158-163 in Studia Evangelica Volume 2: Papers Presented to the Second International Congress on New Testament Studies Held at Christ Church, Oxford, 1961. Edited by F.L. Cross. Berlin: Akademie Verlag, 1964.

Daube, David. The New Testament and Rabbinic Judaism, Jordan Lectures in Comparative Religion. London: Athlone Press, 1956.

Davies, Margaret. Rhetoric and Reference in the Fourth Gospel. Journal for the Study of the New Testament Supplement Series, 69. Sheffield: JSOT, 1992.

Davies, P.R. and B.D. Chilton. "The Aqedah: A Revised Tradition History." Catholic Biblical Quarterly 40 (1978): 514-546.

Delcor, M. "The Apocrypha and Pseudepigrapha of the Hellenistic Period." Pages 409-503 in The Cambridge History of Judaism II The Hellenistic Age. Edited by W.D. Davies and L. Finkelstein. Cambridge: Cambridge University Press, 1989.

Dennis, John. Jesus' Death and the Gathering of True Israel: The Johannine Appropriation of Restoration Theology in the Light of John 11:47-52. WUNT, Tübingen: Mohr, 2006.

Dennis, John. "Jesus' Death in John's Gospel: A Survey of Research from Bultmann to the Present with Special Reference to the Johannine Hyper-Texts." Currents in Biblical Research 4 (2006): 331-363.

Dennis, John. "Conflict and Resolution: John 11.47-53 as the Ironic Fulfillment of the Main Plot-Line of the Gospel (John 1.11-12)." Studien zum Neuen Testament und seiner Umwelt 29 (2004): 23-39.

Dennis, John. "The Presence and Function of Second Exodus-Restoration Imagery in John 6." Studien zum Neuen Testament und seiner Umwelt 30 (2005): 106-121.

Dennis, John. "Restoration in John 11,47-52: Reading the Key Motifs in their Jewish Context." Ephemerides Theologicae Lovanienses 81 (2005): 57-86. 
Devillers, Luc. La Saga de Siloé: Jésus et la fête des Tentes (Jean 7,1-10,21). Paris: Cerf, 2005.

DeVries, Simon J. 1 and 2 Chronicles. The Forms of the Old Testament Literature. Grand Rapids: Eerdmans, 1989.

Dietzfelbinger, Christian. Das Evangelium nach Johannes 1-11. Zürich: Theologischer Verlag, 2001.

Dietzfelbinger, Christian. Das Evangelium nach Johannes. Zürcher Bibelkommentare: NT. Zürich: Theologischer Verlag, 2001.

Dillard, Raymond. 2 Chronicles. Word Biblical Commentary. Waco, Tex: Word Books, 1987.

Dodd, C.H. The Interpretation of the Fourth Gospel. Cambridge: University Press, 1954.

Doran, Robert. "2 Maccabees." Pages 181-299 in New Interpeter's Bible, vol. 4. Edited by Leander Keck. Abingdon Press, 2003.

Doran, Robert. Temple Propaganda: The Purpose and Character of 2 Maccabees. Catholic Biblical Quarterly Monograph Series 12. Washington D.C.: Catholic Biblical Association, 1981.

Duke, Paul D. Irony in the Fourth Gospel. Atlanta: John Knox Press, 1985.

Dunn, James D.G., ed. Jews and Christians: The Parting of the Ways, A.D. 70 to 135; the Second Durham Tübingen Research Symposium on Earliest Christianity and Judaism, Durham, September, 1989. WUNT, 66. Tübingen: Mohr, 1992.

Dunn, James D.G. “John VI - A Eucharistic Discourse?” New Testament Studies 17 (1971): 328-338.

Du Rand, Jan. "A Syntactical and Narratological Reading of John 10 in Coherence with Chapter 9." Pages 94-115 in The Shepherd Discourse of John 10 and its Context. Edited by Johannes Beutler and Robert Fortna; Cambridge: Cambridge University Press, 1991.

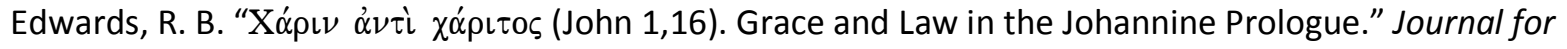
the Study of the New Testament 32 (1988): 3-15.

Ekblad, Eugene Robert. Isaiah 's Servant Poems according to the Septuagint: An Exegetical and Theological Study, Contributions to Biblical Exegesis and Theology. Leuven: Peeters, 1999.

Ellis, E. Earle. Paul's Use of the Old Testament. Edinburgh: Oliver and Boyd, 1957.

Ellis, Peter F. The Genius of John: A Composition-critical Commentary on the Fourth Gospel. Collegeville, Minn: Liturgical Press, 1984.

Endres, John C. "Theology of Worship in Chronicles." Pages 165-188 in The Chronicler as Theologian: Essays in Honor of Ralph W. Klein. Edited by M. Patrick Graham, Steven L. McKenzie and Garry N. Knoppers. Journal for the Study of the Old Testament Supplement Series 371; London: T \& T Clark, 2003. 
Epp, Eldon Jay. "Wisdom, Torah and Word: The Johannine Prologue and the Purpose of the Fourth Gospel." Pages 128-146 in Current Issues in Biblical and Patristic Interpratation. Edited by Gerald F. Hawthorne. Grand Rapids: Eerdmans, 1975.

Evans, Craig A. "On the Quotation Formulas in the Fourth Gospel." Biblische Zeitschrift 26 (1982): 79-83.

Evans, Craig A. "The Function of Isaiah 6:9-10 in Mark and John." Novum Testamentum 24 (1982): 124138.

Evans, Craig A. To See and Not Perceive: Isaiah 6:9-10 in Early Jewish and Christian Interpretation. Sheffield: JSOT Press, 1989.

Evans, Craig A. Word and Glory: On the Exegetical and Theological Background of John's Prologue. Journal for the Study of the New Testament, 89, Supplement series. Sheffield: JSOT Press, 1993.

Evans, Craig A. "Exile and Restoration." Pages 299-328 in Exile: Old Testament, Jewish and Christian Conceptions. Edited by James M. Scott. Supplements to the Journal for the Study of Judaism; Leiden: Brill, 1997.

Farmer, William Reuben. Maccabees, Zealots and Josephus: An Inquiry into Jewish Nationalism in the Greco-Roman Period. New York: Columbia UP, 1956.

Fee, G. “Once more - John 7:37-39.” Expository Times 89 (1978): 116-118.

Fensham, F. Charles. The Books of Ezra and Nehemiah, New International Commentary on the Old Testament. Grand Rapids, Mich: Eerdmans, 1982.

Fenton, J. C. The Gospel according to John: In the Revised Standard Version, New Clarendon Bible. Oxford: Clarendon, 1970.

Feuillet, A. Johannine Studies. Translated by Thomas E. Crane.Staten Island, N.Y.: Alba House, 1965.

Fischer, T. "Maccabees, Books of." Pages 439-450 in The Anchor Bible Dictionary, vol. 4. Edited by David Noel Freedman. New York: Doubleday, 1992.

Fitzmyer, Joseph. "The sacrifice of Isaac in Qumran literature." Biblica 83 (2002): 211-229.

Forestell, J. Terence. The Word of the Cross: Salvation as Revelation in the Fourth Gospel. Analecta Biblica; Rome: Biblical Institute Press, 1974.

France, R.T. “Chronological Aspects of 'Gospel Harmony'.” Vox Evangelica 16 (1986): 33-59.

Freed, Edwin D. Old Testament Quotations in the Gospel of John. Supplements to Novum Testamentum, 11. Leiden: Brill, 1965.

Frisch, A. "The Exodus Motif in 1 Kings 1-14." Journal for the Study of the Old Testament 87 (2000): 3-21. Gärtner, Bertil. John 6 and the Jewish Passover. Lund: C.W.K. Gleerup, 1959. 
Geiger, Georg. "Aufruf an Rückkehrende Zum Sinn des Zitats von Ps 78,24b in Joh 6,31." Biblica 65 (1984): 449-464.

Glasson, Thomas Francis. Moses in the Fourth Gospel, Studies in Biblical Theology. London: SCM Press, 1963.

Goldstein, J.A. I Maccabees. Anchor Bible 41. New York: Doubleday, 1976.

Goldstein, J.A. II Maccabees, Anchor Bible 41a. New York: Doubleday, 1983.

Grassi, Joseph A. "Eating Jesus' Flesh and Drinking His Blood: The Centrality and Meaning of John 6:5158." Biblical Theology Bulletin 17 (1987): 24-30.

Grelot, Pierre. "'De son ventre couleront des fleuves d'eau ' La citation scipturaire de Jean, VII, 38." Revue Biblique 66 (1959): 369-374.

Grelot, Pierre. "A propos de Jean VII, 38." Revue Biblique 67 (1960): 224-225.

Grelot, Pierre. "Jean VII,38: eau du rocher ou source du Temple." Revue Biblique 70 (1963): 43-51.

Grigsby, Bruce H. "The Cross as an Expiatory Sacrifice in the Fourth Gospel." Journal for the Study of the New Testament 15 (1982): 51-80.

Grigsby, Bruce H. "'If Any Man Thirsts': The Rabbinic Background of John 7:37-39." Biblica 67 (1986): 101-108.

Guilding, Aileen. The Fourth Gospel and Jewish Worship: A Study of the Relation of St John's Gospel to the Ancient Jewish Lectionary System. Oxford: Clarendon Press, 1960.

Haenchen, Ernst. John 1: A Commentary on the Gospel of John, Chapters 1-6. Philadelphia: Fortress Press, 1984).

Haenchen, Ernst. John 2: A Commentary on the Gospel of John, Chapters 7-21. Philadelphia: Fortress Press, 1984.

Hakola, Raimo. Identity Matters: John, the Jews and Jewishness. Supplements to Novum Testamentum. Leiden: Brill, 2005.

Hanson, Anthony Tyrrell. "John I. 14-18 and Exodus XXXIV." New Testament Studies 23 (1976): 90-101. Hanson, Anthony Tyrrell. The Prophetic Gospel: A Study of John and the Old Testament. Edinburgh: T \& T Clark, 1991.

Hanson, Anthony Tyrell. Jesus Christ in the Old Testament. London: SPCK, 1965.

Hanson, Anthony Tyrrell. The New Testament Interpretation of Scripture. London: SPCK, 1980. 
Harris, Elizabeth. Prologue and Gospel: The Theology of the Fourth Evangelist. Journal for the Study of the New Testament Supplement Series, 107. Sheffield: Sheffield Academic Press, 1994.

Harrison, Everett F. "A Study of John 1:14." Pages 23-35 in Unity and Diversity in New Testament Theology: Essays in Honor of George E. Ladd. Edited by Robert Guelich. Grand Rapids: Eerdmans, 1978.

Heger, Paul. "Tosefta and historical memory: the Sukkot water libation," Pages 277-301 in Introducing Tosefta. Edited by Paul Heger. Hoboken, N.J. : KTAV, 1999; Ithaca, NY: Snow Lion Publications, 2002.

Hengel, Martin. The Zealots: Investigations into the Jewish Freedom Movement in the Period from Herod I Until 70 A.D. Edinburgh: T. \& T. Clark, 1989.

Hengel, Martin. "The Dionysiac Messiah." Pages 293-332 in Studies in Early Christology. Edited by Martin Hengel. Edinburgh: T\&T Clark, 1995.

Hodges, Z. “Rivers of Living Water - John 7:37-39." Bibliotheca Sacra, 136 (1979): 239-248.

Hodges, Z. “Grace after Grace - John 1:16." Bibliotheca Sacra 135 (1978): 34-45.

Hooker Morna D. "John the Baptist and the Johannine Prologue." New Testament Studies 16 (19691970): 354-358.

Horbury, William. "The Gifts of God in Ezekiel the Tragedian." Pages 65-82 in Messianism Among Jews and Christians: Twelve Biblical and Historical Studies. Edited by William Horbury. London: T \& T Clark, 2003.

Horbury, William. "The Twelve and the Phylarchs." Pages 157-188 in Messianism Among Jews and Christians. Edited by William Horbury. London: T\&T Clark, 2003.

Horbury, William. Messianism Among Jews and Christians: Twelve Biblical and Historical Studies. London: T \& T Clark, 2003.

Horsley, Richard A. Jesus and the Spiral of Violence: Popular Jewish Resistance in Roman Palestine. Minneapolis: Fortress, 1993.

Hoskyns, Edward C. The Fourth Gospel. London: Faber and Faber, 1940.

Hoskins, Paul M. Jesus as the Fulfillment of the Temple in the Gospel of John. Paternoster Biblical Monographs; Milton Keynes : Paternoster, 2006.

Hunter, A. M. The Gospel According to John, The Cambridge Bible Commentery. Cambridge: Cambridge University Press, 1965.

Hylen, Susan. Allusion and Meaning in John 6, Beihefte Zur Zeitschrift Für Die Neutestamentliche Wissenschaft, 137. Berlin: Walter de Gruyter, 2005.

Japhet, Sara. I \& I/ Chronicles: A Commentary, The Old Testament Library. Louisville, Ky: Westminster/John Knox Press, 1993. 
Jeremias, Joachim. The Eucharistic Words of Jesus, New Testament Library. Translated by Norman Perrin from the German 3rd ed., with the author`s revision to July 1964, London: SCM, 1966.

Johnson, Luke T. "The New Testament's Anti-Jewish Slander and the Conventions of Ancient Polemic." Journal of Biblical Literature 108 (1989): 419-41.

Johnstone, William. 1 and 2 Chronicles, Vols 1,2. Journal for the Study of the Old Testament Supplement. Sheffield: Sheffield, 1997.

Jones, Larry Paul. The Symbol of Water in the Gospel of John. Journal for the Study of the New Testament Supplement. Sheffield: Sheffield, 1997.

deJonge, Marinus. "Jesus' Death for Others and the Death of the Maccabean Martyrs." Pages 142-151 in Text and Testimony: Essays on New Testament and Apocryphal Literature in Honour of A.F.J. Klijn. Edited by T.Baarda, A. Hilhorst, G.P. Luttikhuizen, A.S. van der Woude. Kampen: Kok, 1988.

Jones, Larry Paul. The Symbol of Water in the Gospel of John. Journal for the Study of the New Testament Supplement Series, 145. Sheffield: Sheffield, 1997.

Keck, Leander E. "Derivation as Destiny: 'Of-ness' in Johannine Christology, Anthropology and Soteriology." Pages 274-288 in Exploring the Gospel of John: In Honor of D. Moody Smith. Edited by R. Alan Culpepper and C. Clifton Black. Louisville: Westminster John Knox, 1996.

Keener, Craig S. The Gospel of John: A Commentary. 2 vols. Peabody, Mass: Hendrickson, 2003.

Kerr, Alan R. The Temple of Jesus' Body: The Temple Theme in the Gospel of John. Journal for the Study of the New Testament Supplement Series 220. Sheffield: Sheffield University Press, 2002.

Kierspel, Lars. “'Dematerializing' Religion: Reading John 2-4 as a Chiasm.” Biblica 89 (2008): 526-554.

Kierspel, Lars. The Jews and the World in the Fourth Gospel: Parallelism, Function, and Context. Wissenschaftliche Untersuchungen Zum Neuen Testament; Tübingen: Mohr, 2006.

Kilmarten, Edward J. “Liturgical Influence on John 6.” Catholic Biblical Quarterly 22 (1960): 183-191.

Kilpatrick, G.D. “The Punctuation of John vii.37-38.” Journal of Theological Studies 11 (1960): 340-342.

Knapp, Henry M. "The Messianic Water that Gives Life to the World." Horizons in Biblical Theology 19 (1997): 107-121.

Koester, Craig R. Symbolism in the Fourth Gospel: Meaning, Mystery, Community. 2nd ed. Minneapolis: Fortress Press, 2003.

Koester, Craig R. "The Death of Jesus and the Human Condition: Exploring the Theology of John's Gospel." Pages 141-157 in Life in Abundance: Studies in John's Gospel in Tribute to Raymond E. Brown, S.S. Edited by John R. Donahue, S.J. Minnesota: Liturgical Press, 2005. 
Koester, Craig R. "Messianic Exegesis and the Calling of Nathanael." Journal for the Study of the New Testament 39 (1990): 23-34.

Koester, Craig R. "The Death of Jesus in the Gospel of John." Tidsskrift for Teologi og Kirke 75 (2004): 254-76.

Koester, Craig R. The Dwelling of God: The Tabernacle in the Old Testament, Intertestamental Jewish Literature and the Old Testament. Catholic Biblical Quarterly Monograph Series, 22. Washington, D.C: Catholic Biblical Association of America, 1989.

Köstenberger, Andreas J. "Destruction of the Second Temple and the Composition of the Fourth Gospel." Trinity Journal 26 (2005): 205-42.

Köstenberger, Andreas J. The missions of Jesus and the disciples according to the Fourth Gospel : with implications for the Fourth Gospel's purpose and the mission of the contemporary church. Grand Rapids, Mich.: W.B. Eerdmans, 1998.

Köstenberger, Andreas J. John. Grand Rapids, Mich.: Baker Academic, 2004.

Kovacs, Judith L. "Now Shall the Ruler of This World be Driven Out': Jesus' Death as Cosmic Battle in John 12:20-36." Journal of Biblical Literature 114 (1995): 227-247.

Kuhn, K. “St John 7:37-8." New Testament Studies 4 (1957): 63-65.

Kuyper, Lester J. "Grace and Truth: An Old Testament Description of God, and Its Use in the Johannine Gospel." Interpretation 18 (1964): 3-19.

Kuyper, Lester J. "'Truth', a Key Word in St. John's Gospel." Pages 3-23 in Studia Evangelica Volume 2: Papers Presented to the Second International Congress on New Testament Studies Held at Christ Church, Oxford, 1961. Edited by F.L. Cross. Berlin: Akademie Verlag, 1964.

Kysar, Robert. “John 10:22-30." Interpretation 43 (1989): 66-70.

Kysar, Robert. "Historical Puzzles in John." Pages 77-107 in Voyages with John: Charting the Fourth Gospel. Edited by Robert Kysar. Waco, TX: Baylor University Press, 2005.

Kysar, Robert. John, Augsburg Commentary on the New Testament. Minneapolis: Augsburg, 1986.

Lagrange, Marie-Joseph. Évangile selon saint Jean, Études bibliques. 5. éd. Paris: J. Gabalda, 1936.

Le Déaut, Roger. La Nuit Pascale: essai sur la signification de la Pâque juive à partir du Targum d'Exode XII 42. Analecta biblica, Rome: Institut biblique pontifical, 1963.

Levenson, Jon D. “The Temple and the World." Journal of Religion 64 (1984): 275-298.

Levenson, Jon D. Creation and the Persistence of Evil: The Jewish Drama of Divine Omnipotence. Mythos Series. Princeton: Princeton University Press, 1994. 
Levenson, Jon D. Theology of the Program of Restoration of Ezekiel 40-48, Harvard Semitic Monographs. Missoula. Mont: Scholars Press, 1976.

Lincoln, Andrew T. "I Am the Resurrection and the Life: The Resurrection Message of the Fourth Gospel." Pages 122-146 in Life in the Face of Death: The Resurection Message of the New Testament. Edited by Richard Longenecker. Grand Rapids: Eerdmans, 1998.

Lincoln, Andrew T. The Gospel according to Saint John, Black's New Testament Commentaries. London: Continuum, 2005.

Lincoln, Andrew T. Truth on Trial: The Lawsuit Motif in the Fourth Gospel. Peabody, Massachusetts: Hendrickson, 2000.

Lindars, Barnabas. The Gospel of John. New Century Bible. London: Oliphants, 1972.

Little, Edmund. Echoes of the Old Testament in the Wine of Cana in Galilee (John 2.1-11) and the Multiplication of the Loaves and Fish (John 6.1-15). Cahiers De La Revue Biblique. Paris: Gabalda, 1998.

Loader, W.R.G. "The Central Structure of Johannine Christology." New Testament Studies 30 (1984): 188216.

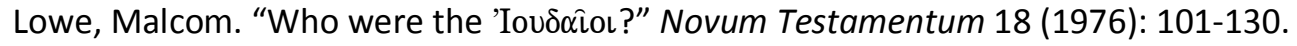

MacRae, George W. "Meaning and Evolution of the Feast of Tabernacles." Catholic Biblical Quarterly 22 (1960): 251-276.

Malatesta, Edward. Interiority and covenant: a study of ' $\epsilon \iota \nu \alpha \iota \epsilon \nu^{\prime}$ and ' $\mu \epsilon \nu \epsilon \nu \epsilon^{\prime}$ ' in the first letter of Saint John. Analecta Biblica. Rome: Biblical Institute Press, 1978.

Manning, Gary T. Echoes of a Prophet: The Use of Ezekiel in the Gospel of John and in the Literature of the Second Temle Period. Journal for the Study of the New Testament Supplement Series, 270. London: T \& T Clark, 2004.

Manne, J., and I. Sonne. The Bible as Read and Preached in the Old Synagogue, 2 vols. Cincinnati, OH: 1940, 1966.

Manns, Fréderic. "Note on the Sacrifice of Isaac in the Fourth Gospel." Pages 99-100 in The Sacrifice of Isaac in the Three Monotheistic Religions. Edited by Frederic Manns. Studium Biblicum Franciscanum Analecta, 41; Jerusalem: Franciscan, 1995.

Maritz, Petrus and Gilbert Van Belle. "The Imagery of Eating and Drinking in John 6:35." Pages 333-352 in Imagery in the Gospel of John. Edited by Jorg Frey. WUNT 200; Tübingen: Mohr, 1996.

Marsh, John. The Gospel of Saint John. Pelican New Testament Commentaries. Harmondsworth, Middlesex: Penguin Books, 1968.

Martin, Michael W. “Betrothal Journey Narratives." Catholic Biblical Quarterly 70 (2008): 505-523. 
Martyn, J. Louis. History \& Theology in the Fourth Gospel. 2nd ed., revised and enlarged. Nashville: Abingdon, 1979.

Mason, Steve. Judaean War 2: Translation and Commentary. Flavius Josephus : Translation and Commentary. Leiden: Brill, 2008.

McWhirter, Jocelyn. The Bridegroom Messiah and the People of God: Marriage in the Fourth Gospel. Society for New Testament Studies Monograph Series, Cambridge: Cambridge University Press, 2006.

Meeks, Wayne A. The Prophet-king: Moses Traditions and the Johannine Christology. Supplements to Novum Testamentum, 14. Leiden: Brill, 1967.

Meier, John P. "Jesus, the Twelve, and the Restoration of Israel." Pages 365-404 in Restoration: Old Testament, Jewish and Christian Perspectives. Edited by ed. James M. Scott. Supplements to the Journal for the Study of Judaism; Leiden: Brill, 2001.

Meier, John P. A Marginal Jew: Rethinking the Historical Jesus, vol. 3. The Anchor Bible Reference Library. New York: Doubleday, 1991, 148-163.

Menken, M.J.J. "The Origin of the Old Testament Quotation in John 7:38." Novum Testamentum 38 (1996): 160-175.

Menken, M.J.J. "The Textual Form and the Meaning of the Quotation from Zechariah 12:10 in John 19:37." Catholic Biblical Quarterly 55 (1993): 494-511.

Menken, M. J. J. "Observations on the significance of the Old Testament in the fourth gospel." Pages 155-175 in Theology and Christology in the Fourth Gospel. Edited by Gilbert van Belle, J.G. Van der Watt, P.J. Maritz. Leuven : Leuven University Press, 2005.

Menken, M. J. J. Old Testament Quotations in the Fourth Gospel: Studies in Textual Form. Kampen: Kok Pharos, 1996.

Meshorer, Ya'akov. Jewish Coins of the Second Temple Period. Tel Aviv: Am Hasefer, 1967.

Moberly, R. W. L. At the Mountain of God: Story and Theology in Exodus 32-34, Journal for the Study of the Old Testament Supplement. Sheffield: JSOT Press, 1983.

Moloney, Francis J. Belief in the Word: Reading the Fourth Gospel John 1-4. Minneapolis: Fortress, 1993.

Moloney, Francis J. Signs and Shadows: Reading John 5-12. Minneapolis: Fortress, 1996.

Moloney, Francis J. Glory not Dishonour: Reading John 13-21. Minneapolis: Fortress, 1998.

Moloney, Francis J. The Gospel of John, Sacra Pagina Series, 4. Collegeville: Liturgical, 1998.

Moloney, Francis J. "Narrative and Discourse at the Feast of Tabernacles." Pages 155-172 in Word, Theology and Community in the Gospel of John. Edited by John Painter, R. Alan Culpepper and Fernando Segovia. St. Louis, MO: Chalice Press, 2002. 
Moloney, Francis J. "The Function of Prolepsis in the Interpretation of John 6." Pages 129-148 in Critical Readings of John 6. Edited by R. Alan Culpepper. Biblical Interpretation Series; Leiden: Brill, 1997.

Montgomery, James A. "Hebrew Hesed and Greek Charis." Harvard Theological Review 32 (1939): 97101.

Moo, Douglas J. The Old Testament in the Gospel Passion Narratives. Sheffield, England: Almond Press, 1983.

Morgan, Richard. "Fulfillment in the Fourth Gospel: The Old Testament Foundations." Interpretation 11 (1957): 155-165.

Morkholm, Otto. Antiochus IV of Syria. København : Nordisk, 1966.

Morris, Leon. The Gospel According to John. New International Commentary on the New Testament. Rev. ed. Grand Rapids: Eerdmans, 1995.

Motyer, Stephen. Your Father the Devil? A New Approach to John and 'the Jews'. Carlisle: Paternoster Press, 1997.

Moule, C.F.D. “A Note on Didache IX.4." Journal of Theological Studies 6 (1955): 240-243.

Moulton, James Hope and George Milligan. The Vocabulary of the Greek Testament: Illustrated from the Papyri and Other Non-literary Sources. London: Hodder and Stoughton, 1930.

Mowvley, Henry. “John 1:14-18 in the Light of Exodus 33:7-34:35." Expository Times 95 (1984): 135-137.

Neyrey, Jerome H. The Gospel of John, New Cambridge Bible Commentary. Cambridge: Cambridge University Press, 2006.

Neyrey, Jerome H. An Ideology of Revolt: John's Christology in Social Science Perspective. Eugene, Oregon: Wipf \& Stock, 2007.

Ng, Wai-yee. Water Symbolism in John: An Eschatalogical Interpretation. Studies in Biblical Literature. New York: Peter Lang, 2001.

Nickelsburg, George W. E. Jewish Literature Between the Bible and the Mishnah: A Historical and Literary Introduction. Philadelphia: Fortress Press, 1981.

Nicklaus, Tobias. "Der Historiker als Erzahler zur Zeichnung des Seleukidenkonigs Antiochus in 2 Makk IX." Vetus Testamentum 52 (2002): 80-92.

Nielson, Jesper Tang. "The Lamb of God: The Cognitive Structure of a Johannine Metaphor." Pages 217256 in Imagery in the Gospel of John. Wissenschaftliche Untersuchungen Zum Neuen Testament 200. Edited by Jorg Frey. Tübingen: Mohr, 1996.

Nodet, Étienne. “La Dedicace, Les Maccabées et Le Messie.” Revue Biblique 93 (1986): 321-375. 
Obermann, Andreas. Die christologische Erfülling der Schrift im Johannesevangelium: eine Untersuchung zur johanneischen Hermeneutik anhand der Schriftzitate. Wissenschaftliche Untersuchungen zum Neuen Testament. Tübingen: J C B Mohr, 1996.

Odeberg, Hugo. The Fourth Gospel: Interpreted in Its Relation to Contemporaneous Religious Currents in Palestine and the Hellenistic-Oriental World. Amsterdam: B. R. Grüner, 1968.

O'Donnell, Tim. "Complementary Eschatologies in John 5:19-30." Catholic Biblical Quarterly 70 (2008): 750-765.

Okure, Teresa. The Johannine Approach to Mission: A Contextual Study of John 4:1-42. Wissenschaftliche Untersuchungen Zum Neuen Testament; Tübingen: Mohr, 1988.

Olsson, Birger. Structure and Meaning in the Fourth Gospel: A Text- Linguistic Analysis of John 2:1-11 and 4:1-42. Coniectanea Biblica, 6. New Testament series. Lund: CWK Gleerup, 1974.

Painter, John. The Quest for the Messiah: The History, Literature, and Theology of the Johannine Community. 2nd ed., revised and enlarged. Edinburgh: T\&T Clark, 1993.

Painter, John. "Tradition, History and Interpretation in John 10." Pages 53-75 in The Shepherd Discourse of John 10 and its Context. Edited by Johannes Beutler and Robert Fortna. Cambridge: Cambridge University Press, 1991.

Pancaro, Severino. The Law in the Fourth Gospel: The Torah and the Gospel Moses and Jesus. Judaism and Christianity According to John. Supplements to Novum Testamentum, 42. Leiden: Brill, 1975.

Parker, Victor L. “Judas Maccabaeus' Campaigns against Timothy." Biblica 87 (2006): 457-476.

Patai, R. Man and Temple in Ancient Jewish Myth and Ritual. New York: Ktav, 1967.

Patai, R. "Control of Rain in Ancient Palestine." Hebrew Union College Annual 14 (1939): 253-278.

Petuchowski, J. “'Hoshi’ah na' in Psalm 118:25 - Prayer for Rain.” Vetus Testamentum 5 (1955): 266-271.

Pitre, Brant. Jesus, the Tribulation, and the End of the Exile: Restoration Eschatology and the Origin of the Atonement. Grand Rapids, Mich: Baker Academic, 2005.

Porter, Stanley. "Can traditional Exegesis Enlighten Literary Analysis of the Fourth Gospel? An Examination of the Old Testament Fulfillment Motif and the Passover Theme." Pages 396-428 in The Gospels and the Scriptures of Israel. Journal for the Study of the New Testament Supplement. Edited by eds. Craig A. Evans and W. Richard Stegner. Sheffield: Sheffield Academic Press, 1994.

Potterie, I. de la. "'Nous adorons, nous, ce que nous connaissons, car le salut vient des Juifs'. Histoire de l'exégèse et interpretation de Jn 4:22." Biblica 64 (1983): 74-115.

Puech, Émile. “Fragment d'une Apocalypse en Araméen (4Q246 = pseudo-Dan d) et le 'Royaume de Dieu'." Revue Biblique 99 (1992): 98-131. 
Reim, Günter. Studien zum alttestamentlichen Hintergrund des Johannesevangeliums. Monograph series, Society for New Testament Studies; Cambridge: Cambridge University Press, 1974.

Reinhartz, Adele. Befriending the Beloved Disciple: A Jewish Reading of the Gospel of John. London: Continuum, 2001.

Ridderbos, Herman. The Gospel According to John: A Theological Commentary. Grand Rapids: Eerdmans, 1997.

Riley, William. King and Cultus in Chronicles: Worship and the Reinterpretation of History. Journal for the Study of the Old Testament Supplement. Sheffield: JSOT Press, 1993.

Robert, R. “Approche littéraire de Jean, VII, 37-39.” Revue Thomiste 86 (1986): 257-268.

Ronning, John L. "The Targum of Isaiah and the Johannine Literature." Westminster Theological Journal 69 (2007): 247-278.

Roth, C. "Messianic Symbols in Palestinian Archaeology." Palestinian Exploration Quarterly 87 (1955): 151-164.

Routledge, Robin. "Passover and Last Supper." Tyndale Bulletin 53 (2002): 203-221.

Rubenstein, Jeffrey L. "Sukkot, Eschatology and Zechariah 14." Revue Biblique 103 (1996): 161-195.

Rubenstein, Jeffrey L. The History of Sukkot in the Second Temple and Rabbinic Periods. Atlanta, Georgia: Scholars Press, 1995.

Rubenstein, Jeffrey. "The Sukkot Wine Libation." Pages 575-591 in Ki Baruch Hu: Ancient Near Eastern, Biblical and Judaic Studes in Honor of Baruch A. Levine. Edited by Robert Chazan, William W. Hallo and Lawrence H. Schiffman. Winona Lake: Eisenbrauns, 1999.

Sabbe, M. "John 10 and its Relationship to the Synoptic Gospels." Pages 75-93 in The Shepherd Discourse of John 10 and its Context. Edited by Johannes Beutler and Robert Fortna; Cambridge: Cambridge University Press, 1991.

Safrai, S. "Home." Pages 728-792 in The Jewish People in the First Century: Historical Geography, Political History, Social, Cultural and Religious Life and Institutions, vol. 2. Edited by S. Safrai and M. Stern.

Amsterdam: Van Gorcum, 1976.

Sandelin, Karl-Gustav. Wisdom as nourisher : a study of an Old Testament theme, its development within early Judaism and its impact on early Christianity. Abo : Abo Akademi, 1986.

Sanders, E.P. Jesus and Judaism. London: SCM, 1985.

Sanders, Joseph Newbould. A Commentary on the Gospel according to St. John. Edited and completed by B.A. Mastin. Black's New Testament Commentaries; London: Black, 1968. 
Sandy, D. Brent. "John the Baptist's 'Lamb of God' Affirmation in its Canonical and Apocalyptic Milieu." Journal of the Evangelical Theological Society 34 (1991): 447-460.

Schenke, L. Johannes: Kommentar. Dusseldorf, 1998.

Schnackenburg, Rudolf. The Gospel According to St. John. Herder's Theological Commentary on the New Testament. London: Burns \& Oates, 1968-1982.

Schlund, Christine. "Kein Knochen soll gebrochen werden" : Studien zu Bedeutung und Funktion des Pesachfests in Texten des frühen Judentums und im Johannesevangelium. Wissenschaftliche Monographien zum Alten und Neuen Testament; Neukirchen-Vluyn: Neukirchener Verlag, 2005.

Schuchard, Bruce G. Scripture Within Scripture: The Interrelationship of Form and Function in the Explicit Old Testament Citations in the Gospel of John. Dissertation Series. Atlanta, Ga: Scholars Press, 1992.

Schwartz, Daniel R. "Antiochus IV Epiphanes in Jerusalem." Pages 45-56 in Historical Perspectives: From the Hasmoneans to Bar Kokhba in Light of the Dead Sea Scrolls. Edited by David Goodblatt. Studies on the Texts of the Desert of Judah, 37. Leiden: Brill, 2001.

Segal, Alan. The Hebrew Passover: From the Earliest Times to A.D. 70. London: Oxford University Press, 1963.

Senior, Donald. The Passion of Jesus in the Gospel of John. Collegeville, Minn: Liturgical Press, 1991.

daSilva, Alcides Pinto. “Giovanni 7,37-39.” Salesianum 45 (1983): 575-592.

deSilva, David A. 4 Maccabees: Introduction and Commentary on the Greek Text in Codex Sinaiticus Leiden: Brill, 2006.

Skinner, Christopher W. “Another Look at the Lamb of God." Bibliotheca Sacra 161 (2004): 89-104.

Smith, B.D. "The Chronology of the Last Supper." Westminster Theological Journal 53 (1991): 29-45.

Smith, D. Moody. John. Abingdon New Testament Commentaries. Nashville: Abingdon Press, 1999.

Smith, D. Moody. The Theology of the Gospel of John, New Testament Theology, Cambridge: Cambridge University Press, 1995.

Spencer, Patrick E. "Narrative Echoes in John 21: Intertextual Interpretation and Intratextual Connection." Journal for the Study of the New Testament 75 (1999): 49-68.

Spykerboer, H.C. "Isaiah 55:1-5." Pages 357-359 in The book of Isaiah. Edited by Jacques Vermeylen. Bibliotheca Ephemeridum theologicarum Lovaniensium; Leuven: Leuven University Press; : Uitgeverij Peeters, 1989.

Staley, Jeffrey L. The Print's First Kiss: A Rhetorical Investigation of the Implied Reader in the Fourth Gospel. SBL Dissertation Series; Atlanta, GA: Scholars Press, 1988. 
Stibbe, Mark W. G. John as Storyteller: Narrative Criticism and the Fourth Gospel. Cambridge: Cambridge University Press, 1992.

Stuart, Douglas K. Exodus. The New American Commentary. Nashville: B \& H Publishing, 2006.

Swancutt, Dianna. "Hungers Assuaged by the Bread from Heaven." Pages 218-251 in Early Christian Interpretation of the Scriptures of Israel: Investigations and Proposals. Edited by Craig A. Evans and James A. Sanders. JSNTS 148. Sheffield: Sheffield Academic Press, 1997.

Talbert, Charles H. Reading John: A Literary and Theological Commentary on the Fourth Gospel and the Johannine Epistles. Macon, Ga: Smyth \& Helwys, 2005.

Tanzer, Sara J. "The problematic portrayal of 'the Jews' and Judaism in the gospel of John: implications for Jewish-Christian relations." Pages 103-118, 200-206 in Contesting texts: Jews and Christians in conversation about the Bible. Edited by Knowles, Melody D., Menn, Esther, Pawlikowski, John T., Sandoval, Timothy J. Minneapolis: Fortress Press, 2007.

Taylor, N.H. "Palestinian Christianity and the Caligula Crisis." Journal for the Study of the New Testament 61 (1991): 101-124.

Thiselton, Anthony C. The First Epistle to the Corinthians: A Commentary on the Greek Text. The New International Greek Testament Commentary. Grand Rapids, Mich: William B. Eerdmans, 2000.

Throntveit, Mark A. Ezra-Nehemiah. Interpretation. Louisville, Ky: John Knox Press, 1992.

Thyen, Hartwig. "Johannes 10 im Kontext des vierten Evangeliums." Pages 116-134 in The Shepherd Discourse of John 10 and its Context. Edited by Johannes Beutler and Robert Fortna. Cambridge: Cambridge University Press, 1991.

Thyen, Hartwig. Das Johannesevangelium. Tubingen: Mohr Siebeck, 2005.

Ulfgard, Håkan. The Story of Sukkot: The Setting, Shaping, and Sequel of the Biblical Feast of Tabernacles. Beiträge Zur Geschichte Der Biblischen Exegese, 34. Tübingen: Mohr, 1998.

Um, Stephen T. The Theme of Temple Christology in John's Gospel. Library of New Testament Studies; London: T \& T Clark, 2006.

VanderKam, James. "John 10 and the Feast of Dedication." Pages 203-214 in Of Scribes and Scrolls: Studies on the Hebrew Bible, Intertestamental Judaism, and Christian Origins, Presented to John Strugnell on the Occasion of his Sixtieth Birthday. Edited by Harold W. Attridge, John J. Collins, Thomas H. Tobin. Lanham: University Press of America, 1990.

VanderKam, James. "Hanukkah: Its Timing and Significance to 1 and 2 Maccabees." Journal for the Study of the Pseudepigrapha 1 (1987): 23-40.

VanderKam, James. "2 Maccabees 6,7a and Calendrical Change." Journal for the Study of Judaism 12 (1981): 52-74. 
Van Henten, Jan Willem. "The tradition-Historical Background of Rom 3,25: A Search for Pagan and Jewish Parallels." Pages 101-128 in From Jesus to John: Essays on Jesus and New Testament Christology in Honour of Marinus De Jonge. Edited by Martinus C. de Boer. Journal for the Study of the New Testament Supplement Series, 84. Sheffield: JSOT Press, 1993.

Van Henten, Jan Willem. The Maccabean Martyrs as Saviours of the Jewish People: A Study of 2 and 4 Maccabees. Leiden: Brill, 1997.

Vanhoozer, Kevin. "Does the Trinity Belong in a Theology of Religions?" Pages 41-71 in The Trinity in a Pluralistic Age: Theological Essays on Culture and Religion. Edited by Kavin Vanhoozer. Grand Rapids: Eerdmans, 1997.

Vermes, Geza. Scripture and Tradition in Judaism: Haggadic Studies. Studia Post-Biblica; Leiden: Brill, 1961.

Wacholder, B.Z. "The Letter from Judah Maccabee to Aristobulos: Is 2 Maccabees 1:10b-2:18 Authentic?" Hebrew Union College Annual 49 (1978): 89-133.

Waetjen, Herman C. The Gospel of the Beloved Disciple: A Work in two Editions. New York: T \& T Clark, 2005.

Wahlde, Urban C. von. "The Johannine 'Jews': A Critical Survey." New Testament Studies 28 (1982): 3360 .

Wahlde, Urban C. von. "He has Given to the Son to have Life in Himself (John 5,26)." Biblica 85 (2004): 409-412.

Wahlde, Urban C. von. "'The Jews' in the Gospel of John: fifteen years of research (1983-1998)." Ephemerides theologicae Lovanienses 76 (2000): 30-55.

Wallace, Daniel B. Greek Grammar Beyond the Basics: An Exegetical Syntax of the New Testament with Scripture, Subject and Greek Word Index, Grand Rapids: Zondervan, 1996.

Wallace, Ronald S. The Gospel of John Chapters 1-21: Pastoral and Theological Studies. Edinburgh: Rutherford House, 2004.

Webster, Jane S. Ingesting Jesus: Eating and Drinking in the Gospel of John, Society of Biblical Literature Academia Biblica, No.6. Atlanta, Georgia: Society of Biblical Literature, 2003.

Wengst, Klaus. Das Johannesevangelium 1. Teilband, Kapitel 1-10, Theologischer Kommentar zum Neuen Testament. Stuttgart: Verlag W. Kohlhammer, 2000.

Westermann, Claus. The Gospel of John: In the Light of the Old Testament. Peabody: Hendrickson, 1998.

Westcott, Brooke Foss. The Gospel According to St. John: The Greek Text with Introduction and Notes. London: J. Murray, 1908. 
Weyde, Karl William. The Appointed Festivals of YHWH: The Festival Calendar in Leviticus 23 and the Sukkôt Festival in Other Biblical Texts. Forschungen Zum Alten Testament 2. Reihe, 4. Tübingen: Mohr Siebeck, 2004.

Whitacre, Rodney A. Johannine Polemic: The Role of Tradition and Theology. Chico: Scholars Press, 1982.

Whitacre, Rodney A. John, The IVP New Testament Commentary Series. Leicester: IVP, 1999.

Williams, Catrin H. "The Testimony of Isaiah and Johannine Christology." Pages 107-124 in "As Those Who Are Taught": The Interpretation of Isaiah from the LXX to the SBL. Edited by Claire Matthews McGinnis and Patricia K. Tull. Society of Biblical Literature: Atlanta, 2006.

Williams, David S. "Recent Research in 2 Maccabees." Currents in Biblical Research 2 (2003): 69-83.

Williamson, H. G. M. 1 and 2 Chronicles, New Century Bible Commentary Grand Rapids, Mich: Eerdmans, 1982.

Witherington, Ben. John's Wisdom: A Commentary on the Fourth Gospel. Louisville: Westminster John Knox, 1995.

Witkamp, L. "Johannine Features in John 6:1-21." Journal for the Study of the New Testament 40 (1990): 43-60.

Wood, J. Edwin. "Isaac Typology in the New Testament." New Testament Studies 14 (1967-1968): 583589.

Wright, N.T. Jesus and the Victory of God. London: SPCK, 1996.

Wright, N.T. New Testament and the People of God. London: SPCK, 1992.

Zeitlin, Solomon, ed. The Second Book of Maccabees, with Introduction and Commentary. New York: Dropsie College, 1954.

Zerwick, Maximilian. Biblical Greek: Illustrated by Examples, Scripta Pontificii Instituti Biblici. English ed., adapted from 4th Latin ed., Rome, 1963.

Zimmermann, Ruben. "Der Freund des Bräutigams (Joh 3,29): Deflorations- oder Christuszeuge?" Zeitschrift für die neutestamentliche Wissenschaft 90 (1999): 123-130.

Zumstein, J. "L'interprétation johannique de la mort du Christ Pages." Pages 2119-2138 in The Four Gospels. Festschrift Frans Neirynck, III.IV. Edited by F. Van Segbroeck, C.M. Tuckett, G. Van Belle and J. Verheyden. Leuven: Leuven University/Peeters, 1992. 